Göttingen Studies

in Criminal Law and Justice

Kai Ambos, Ottilia A. Maunganidze (Eds.)

African Expert Study Group on International Criminal Law Groupe des Experts Africaines en Droit Pénal International

\title{
Power and Prosecution
}

Challenges and Opportunities for International Criminal Justice in Sub-Saharan Africa

\section{Pouvoir et Poursuite}

Défis et Opportunités pour la Justice Pénale Internationale en Afrique SubSaharienne 

Kai Ambos, Ottilia A. Maunganidze (Eds.)

Power and Prosecution

This work is licensed under the Creative Commons License 3.0 "by-nd", allowing you to download, distribute and print the document in a few copies for private or educational use, given that the document stays unchanged and the creator is mentioned.

You are not allowed to sell copies of the free version.

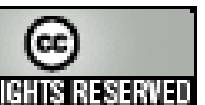

SORIERIGHISRESERVED 
Published als Volume 24 of the series „Göttingen Studies in Criminal Law and Justice“ by Universitätsverlag Göttingen 2012 
Kai Ambos,

Ottilia A. Maunganidze (Eds.)

African Expert Study Group on International Criminal Law

Groupe des Experts Africaines en Droit Pénal International

\section{Power and Prosecution}

Challenges and Opportunities for International Criminal Justice in SubSaharan Africa

Pouvoir et Poursuite

Défis et Opportunités pour la Justice

Pénale Internationale

en Afrique SubSaharienne

with the editorial support by

Sabine Klein and Anett Müller

Göttingen Studies in

Criminal Law and Justice

Volume 24

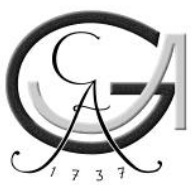

Universitätsverlag Göttingen

2012 
Bibliographische Information der Deutschen Nationalbibliothek

Die Deutsche Nationalbibliothek verzeichnet diese Publikation in der Deutschen Nationalbibliographie; detaillierte bibliographische Daten sind im Internet über $<$ http://dnb.ddb.de> abrufbar.

\title{
Editors of the Series
}

Institute of Criminal Law and Justice

Faculty of Law, Georg-August-Universität Göttingen

Profs. Drs. Kai Ambos, Gunnar Duttge, Jörg-Martin Jehle, Uwe Murmann

\section{Editors of this Volume}

Prof. Dr. Kai Ambos

Judge District Court Göttingen

University of Göttingen

Institute for Criminal Law and

Criminal Justice

Platz der Göttinger Sieben 5

D-37073 Göttingen

Email:kambos@gwdg.de

\author{
Ottilia A. Maunganidze \\ Institute for Security Studies \\ Brooklyn Court \\ 361 Veale Street \\ New Muckleneuk 0075 \\ Pretoria, Republic of South Africa \\ Email: omaunganidze@issafrica.org
}

With financial support of the Konrad Adenauer Stiftung, Berlin

This work is protected by German Intellectual Property Right Law.

It is also available as an Open Access version through the publisher's homepage and the Online Catalogue of the State and University Library of Goettingen

(http://www.sub.uni-goettingen.de). Users of the free online version are invited to read, download and distribute it. Users may also print a small number for educational or private use. However they may not sell print versions of the online book.

C 2012 Universitätsverlag Göttingen

http://univerlag.uni-goettingen.de

ISBN: 978-3-86395-078-1

ISSN: $1864-2136$ 


\section{Table of contents}

Introduction (english version)

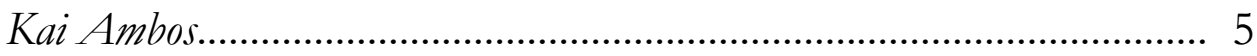

Introduction (version française)

Kai Ambos.............................................................................. 13

South Africa's Implementation of the Rome Statute

(La Mise en œuvre du Statut de Rome en Afrique du Sud)

Du Plessis, Max.

Implementing at national level the amendments to the Rome Statute of the International Criminal Court with respect to the crime of aggression: A South African perspective

(Mise en œuvre des amendements au Statut de Rome en ce qui concerne le crime d'agression au niveau national: Un point de vue Sud-Africain)

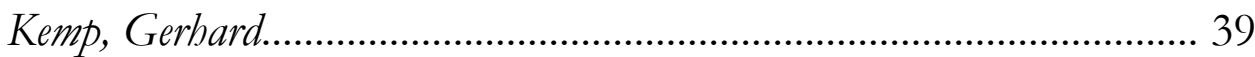

Rwanda and the ICC: a need for the ratification of the Rome Statute

(Le Rwanda et la CPI: une nécessité pour la ratification du Statut de Rome)

Garuka, Cbristian Nsabimana......................................................... 57 
L'impact de la peine de mort dans le processus de l'adoption de la loi de mise en œuvre du Statut de Rome en République Démocratique du Congo

(The impact of the death penalty in the process of adopting the law implementation of the Rome Statute in the Democratic Republic of Congo)

Ngondji Ongombe, Lievin............................................................. 73

Immunity and the implementation legislation in South Africa, Kenya and Uganda

(Immunité en Mise en CEuvre de la Législation en Afrique du Sud, au Kenya et en Ouganda)

Gevers, Christoper...................................................................... 85

The International Criminal Court Factor on Transitional Justice in Kenya

(La Cour Pénale Internationale Facteur de Justice de Transition au Kenya)

Asaala, Evelyne Owiye

Implementing the Rome Statute in Africa: Potential and problems of the prosecution of gender crimes in Africa in accordance with the Rome Statute

(Mise en œuvre du Statut de Rome en Afrique: le potentiel et les problèmes de la poursuite judiciaire des crimes sexuels en Afrique, conformément au Statut de Rome)

Meyersfeld, Bonita.... 
The African Union's decisions on the indictments of Al-Bashir and Gaddafi and their implications for the implementation of the Rome Statute by African States

(Les decisions de l'Union Africaine sur les actes d'accusation d'AlBashir et Kadhafi et leurs implications pour la mise en œuvre du Statut de Rome par les États de l'Afrique)

Lubbe, Hendrik Johannes.................................................................... 179

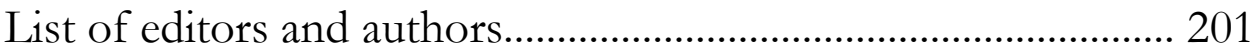





\section{Introduction}

\section{I.}

This book contains some of the papers that were presented at the first meeting of the newly formed 'African Expert Study Group on International Criminal Law' held in September 2011 in Brussels, Belgium. ${ }^{1}$ The group was established under the auspices of the Multinational Development Policy Dialogue (hereinafter 'MDPD') and the Rule of Law programme of the German Konrad-Adenauer-Stiftung ('KAS') in $2010^{2}$ modeled on the successful sister group in Latin America. This latter group was originally founded as an expert group to monitor the implementation of the Rome Statute of the International Criminal Court ('ICC') ${ }^{3}$ in Latin America within the framework of cooperation between KAS' regional Rule of Law Programme and the Department for Foreign and International Law of the Institute for Criminal Law and Criminal Justice of the Georg-August-Universität Göttingen in 2002. In 2006, the Latin American group was renamed 'Latin-American Study Group on International Criminal Law, given its expanded focus. The Latin American group presently has 21 members from 13 Latin-American States (Argentina, Bolivia, Brazil, Chile, Costa Rica, Ecuador, El Salvador, Colombia, Mexico, Paraguay, Peru, Uruguay and Venezuela). It also has members from Germany, Spain, Italy as well as a representative of the ICC. ${ }^{4}$ The members of the group, who have regular con-

\footnotetext{
1 For the conference's programme, see <http://www.kas.de/wf/doc/kas_4739-1442-230.pdf?111005160402> accessed 11 June 2012.

2 See generally on the KAS <www.kas.de> accessed 9 July 2012, and on the Rule of Law programme see < http://africaicl.wordpress.com/> accessed 12 July 2012.

3 Rome Statute of the International Criminal Court, 2187 UNTS 90, 17 July 1998, entered into force 1 July 2002 (Rome Statute).

4 See <http://www.kas.de/rspla-mex/de/pages/10893/> or <www.department-ambos.unigoettingen.de/index.php/en/Forschung/lateinamerikanische-studiengruppe-zum-internationalenstrafrecht.html> accessed 14 July 2012.
} 
Kai Ambos

tact with each other and hold a meeting once a year, are all renowned academics and practitioners in their home countries and particularly active in field of international criminal law.

The newly formed African group consists of judicial experts with both academic and practical background from various parts of Sub-Saharan Africa. The importance of such a group for the African continent cannot be overestimated. Africa plays a vital role in international criminal law and justice, both as an active player at the ICC and at the regional and national level. Notably, Africa has a high number of non-international armed conflicts and, consequently, criminal investigations and prosecutions. In fact, all situations and cases currently under formal investigation before the ICC come from Africa (emerging from situations in the Central African Republic [CAR], the Democratic Republic of Congo [DRC], Ivory Coast, Kenya, Libya, the Darfur region of Sudan and Uganda). ${ }^{5}$ While the ICC enjoys broad support from the African continent (out of 121 States Parties to the Rome Statute, 33 are African $\left.{ }^{6}\right)$, its focus on Africa and in particular the prosecution of a sitting head of state, Omar Hassan al-Bashir of Sudan, has sparked controversy. ${ }^{7}$ Indeed, the African Union issued several decisions calling upon their member states not to cooperate with the ICC regarding the arrest and surrender of al-Bashir. ${ }^{8}$ While the criticism against the ICC is to a certain extent understandable, one must not overlook that there are several reasons why the Court so far predominantly focuses on Africa. These reasons have been explained elsewhere. ${ }^{9}$ Here it suffices to state that three of the countries concerned (CAR, DRC and Uganda) have 'self-referred' situations in their respective countries to the ICC. Further, Ivory Coast - a non-member state - has accepted the jurisdiction of the ICC under Article 12(3) of the Rome Statute. Lastly, the use of the proprio motu power of the Prosecutor according to Article 15 in the situation in Kenya was negotiated beforehand. Nevertheless, it is clear that the ICC's universal reach makes it necessary

\footnotetext{
5 See <www.icc-cpi.int/Menus/ICC/Situations+and+Cases/> accessed 8 July 2012. Of course, preliminary investigations currently also refer to non-African countries, i.e., Afghanistan, Honduras, Korea, Nigeria, Colombia, Georgia and Guinea, see ICC OTP, 'Weekly Briefing', Issue 119 (24 April - 1 May 2012) p. 2 <http://www.icc-cpi.int/NR/rdonlyres/C9C3544A-6558-461A-8FA3D38F2C5FA4A5/284506/OTPWeeklyBriefing24April1May2012.pdf> accessed 11 June 2012.

${ }^{6}$ See <www.icc-cpi.int/Menus/ASP/states+parties/> accessed 8 July 2012.

7 See for an analysis Kai Ambos, 'Expanding the Focus of the "African Criminal Court", in Yvonne McDermott, Niamh Hayes and William A Schabas (eds), Ashgate Research Companion to International Criminal Law: Critical Perspectives (Ashgate, 2012), forthcoming, available at

<http://papers.ssrn.com/sol3/papers.cfm?abstract_id=2017537> accessed 14 June 2012.

8 African Union Assembly, Decision on the Meeting of African States Parties to the Rome Statute of the International Criminal Court (ICC), (3 July 2009) Assembly/AU/Dec.245 (XIII) Rev. 1 Doc. Assembly/AU/13(XIII), p. 2. See also African Union Press Release, 'On the decisions of Pre-Trial Chamber I of the International Criminal Court (ICC) Pursuant to Article 87(7) of the Rome Statute on the Alleged Failure by the Republic of Chad and the Republic of Malawi to Comply with the Cooperation Requests issued by the Court with respect to the Arrest and Surrender of President Omar Hassan Al Bashir of the Republic of the Sudan' (9 January 2012) Press Release No 002/2012.

${ }^{9}$ See Ambos (n 7).
} 
that, in the near future, it should also open investigations into situations outside of Africa.

\section{II.}

The first meeting of African experts in Brussels, referred to above, had as an overall theme 'Power and Prosecution: Challenges and Opportunities for International Criminal Justice in Sub-Saharan Africa'. The theme was discussed from various perspectives and with different focus. Thus, the reader will find essays in the form of country studies on particular African national legislative developments regarding the incorporation of the Rome Statute into domestic law (e.g.: South Africa, Rwanda, Kenya, DRC), and also, unconnected to the developments of specific African countries, assessments of various subjects relevant for the development of international criminal justice in Africa, such as the African Union's influences in domestic implementation of the Rome Statute and the prosecution of sexual and gender based crimes in African contexts. Given the bi-lingual composition of the group, the book contains English and one French paper. All papers contain an abstract in both English and French.

\section{III.}

Max du Plessis' (Institute for Security Studies \& University of KwaZulu-Natal, South Africa) article entitled 'South Africa's Implementation of the Rome Statute' presents an assessment of South Africa's legislation domesticating the Rome Statute. South Africa's Implementation of the Rome Statute of the ICC Act was promulgated in August 2002. Du Plessis explains and analyses the key provisions of the Act. Among other issues, he looks at immunities and examines the South African provisions. He argues that the Act enables South Africa to comply with its obligations deriving from the Rome Statute and forms an appropriate provisional basis to respond to the global demands of criminal justice for international crimes. However, he notes, that the legislation's success depends on the national political will to apply the newly created legal framework in South Africa.

Gerhard Kemp (Stellenbosch University, South Africa), in his contribution entitled 'Implementing the amendments to the Rome Statute with respect to the crime of aggression at national level: A South African perspective', discusses the implementation of the crime of aggression in South Africa. Kemp analyses the implications of the adoption of the crime of aggression at the ICC's 2010 Review Conference in Kampala ${ }^{10}$ for South Africa's domestic law. The South African ICC Act considers aggression as an international crime, and provides for the application

\footnotetext{
${ }^{10}$ Hereto, cf. Kai Ambos, 'The Crime of Aggression after Kampala' German Yearbook of Interna-
} tional Law 53 (2010) 463-509. 
Kai Ambos

of international law. Against this backdrop, the author explores the significance and interpretative value of the Kampala decision, especially for South African law. He argues in favor of the prosecution of aggression at the domestic level.

Christian Garuka Nsabimana (Advocate, Rwanda) offers an account on Rwanda and the ICC with his paper 'Rwanda and the ICC: a need for the ratification of the Rome Statute'. He points out that Rwanda, in spite of being among the few African countries with experiences in the prosecution of international crimes and having a number of nationals being prosecuted by an international criminal tribunal, has not ratified the Rome Statute. He demonstrates relevant developments in Rwanda and presents arguments for and against ratification. While arguing for a need to ratify the Rome Statute, he analyses political and legal implications.

Lievin Ngombe (Association 'Culture for Freedom and Justice', Democratic Republic of Congo), in his paper entitled 'L'impact de la peine de mort dans le processus de l'adoption de la loi de mise en ouvre du statut de Rome en République Démocratique du Congo' ('The impact of the death penalty in the process of adopting the implementation law of the Rome Statute in the Democratic Republic of Congo'), addresses developments regarding the implementation of the Rome Statute in the DRC, especially pointing to the country's adherence to the death penalty. The DRC ratified the Rome Statute and referred a situation to the ICC. However, the Rome Statute has not yet been implemented into domestic law. The paper assesses the DRC's debate on the death penalty and its implications for the implementation of the Rome Statute into domestic law. The author identifies certain contradictions in this regard between the DRC's laws and international criminal law.

Christopher Nsabimana Gevers (University of KwaZulu-Natal, South Africa) offers with his paper 'Immunity and the Implementation Legislation in South Africa, Kenya and Uganda' a comparative study on the contentious issue of immunities. By way of introduction, he discusses the various forms of immunity, their history, recognition under customary international law and related developments. This is followed by an assessment of the Rome Statute's provisions on immunity, especially Articles 27 and 98. For the author, both provisions must be read separately: While Article 27 (2) only guarantees the exclusion of the immunity defence under the Court's jurisdiction, Article 98 (1) refers to 'requests for surrender or assistance' i.e. more broadly relates to the cooperation regime. In the comparative part, the paper addresses immunities for international crimes under Kenyan, Ugandan and South African laws, scrutinizing in particular two questions: first, how far immunities may justify non-cooperation with the ICC in respect of, for example, potential extraditions (a matter of considerable practical importance given the much debated arrest warrants against Sudanese president al-Bashir); and second, how immunities are applicable to domestic prosecutions under the respective national provisions. The author focuses on the legal uncertainties, especially regarding customary international and domestic law, and the applicability of (customary) international law in the African context. In conclusion, the extent of legal 
uncertainty on the international and national level is bewailed, and the African state parties to the Rome Statute are called upon to clarify their position as to immunity.

Evelyne Owiye Asaala (African Nazarene University, Kenya) in her article 'The International Criminal Court Factor on Transitional Justice in Kenya' analyses the impact of the ICC on processes surrounding transitional justice in Kenya in the aftermath of the post-election violence of 2007/08. A Kenyan agenda to deal with the violence developed by the 'Kenya National Dialogue and Reconciliation Committee' (KNDRC) includes constitutional reforms, the establishment of a truth commission, and prosecutions. With the 'International Crimes Act', Kenya incorporated the Rome Statute into its national law in 2008. The contribution analyses the impact of the ICC's investigation on the Kenyan situation and on the national implementation legislation, while at the same time taking into account the principle of complementarity. The Kenyan government's approach regarding complementarity is criticized and the ICC is identified as 'central' in discourses on transitional justice in Kenya. The author sees a far-reaching impact of the ICC's involvement in Kenya on the social, legal and political level, and argues that perceptions towards justice changed through the ICC's investigations.

Bonita Meyersfeld (University of the Witwatersrand School of Law Centre for Applied Legal Studies, South Africa) in her account on 'Implementing the Rome Statute in Africa: Potential and problems of the prosecution of gender crimes in Africa in accordance with the Rome Statute' explores possibilities and challenges of prosecuting sexual and gender crimes in Africa in accordance with the ICC Statute. ${ }^{11}$ Coming along with the increasing attention of sexual and gender based violence (SGBV) in situations where crimes of an international dimension occur, her contribution gives a historical overview of gender specific war crimes prosecutions, identifies types of harms which women experience during conflict and addresses deficiencies in post-conflict prosecutions. As for the latter, she covers some of the conceptual problems, probable investigative activities and organizational structures within the respective prosecutorial bodies (for instance witness' support and protection, and outreach dissemination of relevant proceedings). Endorsing an enhanced prosecution of international sexual crimes, the potential of such development is envisioned. It is argued, that the prosecution of gender related sexual crimes offers possibilities of redress to the often-female victims by holding the perpetrator accountable. She argues further that such prosecutions may lead to future deterrence, in a way that makes the prosecution of SGBV crimes significant not only with regard to individual cases but also to the general prospective safety of women in transitional societies.

\footnotetext{
${ }_{11}$ On the substantive and procedural law as well as the practice of sex crimes and their prosecution see recently Morten Bersmo (ed), Thematic Prosecution on International Sex Crimes (Torkel Opsahl Academic EPublisher 2012); and Morten Bergsmo, Alf Butenschøn Skre, Elisabeth J. Wood (eds), Understanding and Proving International Sex Crimes (Torkel Opsahl Academic EPublisher 2012) (both available at <http://www.fichl.org/publication-series/> accessed 9 July 2012).
} 
Last but not least, Hendrik Johannes Lubbe (University of the North West, South Africa), writes about 'The African Union's decisions on the indictments of AlBashir and Gaddafi and their implications for the implementation of the Rome Statute by African States'. He offers a critical examination of the African Union's decisions on the ICC. He addresses the content of the decisions and some of the background motivations (such as the UN Security Council's inactivity following an African Union request pursuant to article 16 Rome Statute to defer the Darfur situation and personal immunities of serving heads of states). In this respect, Articles 27(2) and 98(1) of the Rome Statute are evaluated while arguing that they should be read together in a supplementary way. The author sees a conflict between the African Union's decisions and the Rome Statute and customary international law. He raises concerns with regard to the fact that some African states have already adhered to the decision, while unlawfully disregarding their obligations deriving from the Rome Statute. Further, he sees the risk that African states may follow the African Union's decision and refrain from ratifying and/or implementing the Rome Statute.

\section{IV.}

As for the group's composition and outreach, the aim is to broaden regional representation and further consolidate membership.

In 2012, the group will meet in Nairobi, Kenya to deal with topics surrounding the 'Potential for the domestic prosecution of international crimes in Africa'. Topics for future meetings abound given the multi-faceted African legal and political practice regarding international criminal justice in general and the ICC in particular. The group should in particular monitor the recent international or transnational criminal justice developments at the regional African level. As to national developments, it is for example worthwhile mentioning that in Uganda amnesty requests on the basis of the blanket amnesty law of 2000 are since 23 May 2012 no longer granted. ${ }^{12}$ After the civil war between the Government of Uganda and the Lord's Resistance Army, this blanket amnesty served as an obstacle to national prosecutions for international crimes, ${ }^{13}$ although in 2008 in Uganda an International Crimes Division was established in the High Court in order to commence such

\footnotetext{
12 Ugandan Minister of Internal Affairs, Statutory Instrument No. 34 of 2012 (23 May 2012), and Ugandan Minister of Internal Affairs, Statutory Instrument No. 35 of 2012 (23 May 2012) (both on file with the author). See also, Justice Law and Order Sector (JLOS), 'The Statue of Amnesty in Uganda (Part 2)' (11 June 2012) <http://www.jlos.go.ug/page.php?p=curnews\&id=89> accessed 5 July 2012.

13 JLOS 'The Amnesty Law (2000) Issues Paper - Review by the Transitional Justice Working Group' (April 2012)

<www.jlos.go.ug/uploads/JLOS-Amnesty $\% 20$ Issues $\% 20$ Paper $\% 20 \% 5$ Bpublic $\% 20$ report $\% 5$ D.pdf> accessed 9 July 2012.
} 
trials. ${ }^{14}$ Given the end of the application of the amnesty, domestic trials have become more feasible.

At the regional level, there has been a renewed attempt to establish supranational African criminal jurisdiction, which should be monitored closely. On the one hand, the East African Legislative Assembly intends to extend the jurisdiction of the East African Court of Justice (EACJ) ${ }^{15}$ to the prosecution of international crimes; ${ }^{16}$ on the other hand, the African Union wants to equip the African Court of Justice and Human Rights with jurisdiction over, amongst others, the crimes of genocide, war crimes and crimes against humanity. ${ }^{17}$

While such a move towards regional criminal justice is, in principle, to be welcomed, the concrete circumstances and motives of certain African states give rise to certain concern. Clearly, the national and regional criminal justice systems need to be strengthened since states where these crimes occur should primarily deal with them. This also corresponds to the idea of positive complementarity promoted by the ICC States Parties and the ICC Prosecutor. ${ }^{18}$

\footnotetext{
${ }^{14}$ Judiciary of the Republic of Uganda, 'The establishment of the International Crimes Division of the High Court'

$<$ http:/ / www.judicature.go.ug/index.php?option=com_content\&task $=$ view\&id $=117 \&$ Itemid=154> accessed 5 July 2012.

${ }^{15}$ For the EACJ's website, see <http://www.eacj.org/> accessed 11 June 2012. The EACJ is a treaty based judicial institution, see Treaty for the Establishment of the East African Community (1999), as last amended on 20 August 2007, arts $28 \mathrm{ff}$.

${ }^{16}$ East African Community, East African Legislative Assembly, 'Resolution of the Assembly seeking the EAC Council of Ministers to implore the International Criminal Court to transfer the case of the accused four Kenyans facing trial in respect of the aftermath of the 2007 Kenya general elections to the East African Court of Justice and to reinforce the treaty provisions' (26 April 2012), $<$ http://www.eala.org/oldsite041111/key-documents/doc_details/80-resolution-urging-the-eacpartner-states-to-halt-the-signing-of-the-eu-eac-epas.html> accessed 11 June 2012.

17 African Union, Meeting of Government Experts and Ministers of Justice/Attorneys General, 'Press Release No 037/2012' (14 May 2012) <www.au.int/en/dp/legal/content/meetinggovernment-experts-and-ministers-justiceattoreys-general> accessed 14 June 2012. See irin news, 'Analysis: How close is an Africa criminal court?' (13 June 2012) Johannesburg <www.irinnews.or/Report/95633/Analysis-How-close-is-a-African-criminal-court> accessed 14 June 2012 ('Plans for an African criminal court moved into an advanced stage with a final draft protocol drawn up in the Ethiopian capital Addis Ababa on 15 May. It is widely expected to be adopted at an AU summit meeting of heads of state in July'). For an scholarly account, see Chacha Bhoke Murungu, 'Towards a Criminal Chamber in the African Court of Justice and Human Rights' (2011) 2 Journal of International Criminal Justice 1067.

${ }_{18}$ In the words of the ICC-OTP, positive complementarity is referred to as a 'proactive policy of cooperation aimed at promoting national proceedings', see ICC/OTP, 'Prosecutorial Strategy 2009 2012' (1 February 2010), p. 5. See for a detailed account William W. Burke-White, 'Implementing a Policy of Positive Complementarity in the Rome System of Justice' (2008) 19 Criminal Law Forum (CLF) 59 ff.; William W. Burke-White, 'Reframing positive complementarity', in CarstenStahn/Mohamed M. El Zeidy (eds), The International Criminal Court and Complementarity - From Theory to Practice, Volume I, pp. 342 ff.; Carsten Stahn, 'Complementarity: A Tale of Two Notions' (2008) 19 CLF 87, 100 ff.; Morten Bergsmo/Olympia Bekou/Annika Jones, 'New Technologies in Criminal Justice for Core International Crimes: The ICC Legal Tools Project' (2010) 10 Human Rights Law Review 715, $723 \mathrm{ff}$.
} 
Such moves must be seen critically, however, if they serve to impede or delay truly independent justice and are motivated by investigations of concrete events and prosecutions of concrete people. This is apparently the case as regards the idea of an East African Court of Justice, which was motivated by the ICC investigation into the post-election violence in Kenya and the arrest warrants against four Kenyan suspects. ${ }^{19}$ Thus, the East African Legislative Assembly made the following statement:

this House resolves [...] (that) the Council of Ministers immediately embarks on the process of requesting the transfer of the proceedings for the accused four suspects in respect of the 2007 general elections from the International Criminal Court and instituting them in the East African Court of Justice on the basis that the acts complained of are contraventions of the Treaty. ${ }^{20}$

Clearly, such a motivation rather shows certain unwillingness by the states concerned to deliver justice than a serious interest in bringing the responsible perpetrators to justice. In fact, it is not too far-fetched to suspect that trials before such a regional court would be 'undertaken [...] for the purpose of shielding' the responsible persons from criminal responsibility and justice. ${ }^{21}$

\section{V.}

As always, this publication has, apart from the authors mentioned above, different mothers and fathers. First of all, Ottilia Anna Maunganidze from the Transnational Threats and International Crime Division of the Institute for Security Studies did a great job as the de facto sole coordinator of the Group to get hold of the drafts, revise them with great precision and ask the authors for correction. From our side Sabine Klein, a researcher in my Department, doctoral candidate in Göttingen and practicing lawyer, supported her. Student research assistant Annika Poschadel helped out with some French correspondence. My secretary Anett Müller made sure that the University publisher got the correctly formatted manuscript. Last but not least, Andrea E. Ostheimer, Programme Director of the MDPD at the KAS' Brussel's office developed the idea of an African expert study group, secured funding, organized the translation of the abstracts and was always available in case of emergency.

\footnotetext{
${ }^{19}$ See the name of the resolution (n 16) demanding 'to implore the International Criminal Court to transfer the case of the accused four Kenyans facing trial in respect of the aftermath of the 2007 Kenya general elections to the East African Court of Justice [...]'.

${ }^{20}$ East African Legislative Assembly (26 April 2012) (n 16), para 4.

${ }^{21}$ Cf. Rome Statute, art 17(2)(a).
} 
This is the first publication of the still quite young African Expert Study Group on International Criminal Law. We hope that there are more to come with a steady rise in quality and regional coverage.

Kai Ambos

Göttingen, July 2012

\section{Introduction}

\section{I.}

Ce livre contient certains des documents qui ont été présentés lors de la première réunion du Groupe d'étude expert africain sur le droit pénal international récemment formé qui s'est tenue en septembre 2011 à Bruxelles, Belgique. ${ }^{22}$ Le groupe a été établi sous les auspices du Dialogue de politique de développement multinational (ciaprès 'DPDM') et du programme de l'Etat de droit de l'allemand KonradAdenauer-Stiftung ('KAS') en $2010^{23}$ sur le modèle du succès affiché par le groupe sœur en Amérique latine. Ce dernier a été à l'origine fondé en tant que groupe d'experts pour surveiller la mise en oeuvre du statut de Rome de la cour pénale internationale ('CPI') 24 en Amérique latine dans le cadre de la coopération entre le Programme pour la promotion de l'état de droit KAS et le département du droit étranger et international de l'institut du droit pénal et de la justice pénale de GeorgAugust-Universität Göttingen en 2002. En 2006, le groupe latino-américain a été renommé Groupe d'étude latino-américain sur le droit pénal international, étant donné la portée de champ d'étude. Le groupe latino-américain réunit actuellement 21 membres de 13 états latino-américains (Argentine, Bolivie, Brésil, Chili, Costa Rica, Equateur, Salvador, Colombie, Mexique, Paraguay, Pérou, Uruguay et Venezuela). Il y a également des membres d'Allemagne, Espagne, Italie ainsi qu'un représentant de la CPI. ${ }^{25}$ Tous les membres du groupe, qui ont des contacts réguliers les uns avec les autres et tiennent une réunion une fois par an, sont des universi-

22 Pour le programme de la conférence, voir le <http://www.kas.de/wf/doc/kas_4739-1442-230.pdf?111005160402> consulté le 11 juin 2012.

${ }^{23}$ Voir généralement sur le KAS < www.kas.de> consulté le 9 juillet 2012, et sur le Programme pour la promotion de l'état de droit voir < http://africaicl.wordpress.com/> consulté le 12 juillet 2012.

${ }^{24}$ Statut de Rome de la cour pénale internationale, 2187 UNTS 90, 17 juillet 1998, entré en vigueur le 1er juillet 2002 (statut de Rome).

25 Voir <http://www.kas.de/rspla-mex/de/pages/10893/> ou <www.department-ambos.unigoettingen.de/index.php/en/Forschung/lateinamerikanische-studiengruppe-zum-internationalenstrafrecht.html> consulté le 14 juillet 2012. 
taires et des praticiens renommés dans leurs pays d'origine et particulièrement actifs dans le domaine du droit pénal international.

Le groupe africain récemment formé se compose d'experts juridiques qui ont une formation universitaire mais aussi une pratique du droit et proviennent de diverses régions de l'Afrique sub-saharienne. L'importance d'un tel groupe pour le continent africain ne peut être surestimée. L'Afrique joue un rôle essentiel dans le droit pénal et la justice internationale, en tant que membre actif à la CPI et au niveau régional et national. Notamment, l'Afrique est le théâtre d'un nombre élevé de conflits armés non-internationaux et, par conséquent, d’investigations et de poursuites criminelles. En fait, toutes les situations et les affaires actuellement objets d'enquête officielle devant la CPI viennent d'Afrique (émergeant des situations en République centrafricaine [RCA], République démocratique du Congo [RDC], en Côte d'Ivoire, Kenya, Libye, dans la région Darfour du Soudan et en Ouganda). ${ }^{26}$ Si la CPI bénéficie d'un large soutient du continent africain (sur 121 parties d'états au statut de Rome, 33 sont africains ${ }^{27}$ ), son intérêt pour l'Afrique et en particulier la poursuite d'un chef d'Etat en exercice, Omar Hassan Al-Bashir du Soudan, a suscité la polémique. ${ }^{28}$ En effet, l'union africaine s'est prononcée à plusieurs reprises, rendant des décisions invitant leurs États Membres à ne pas coopérer avec la CPI concernant l'arrestation et la reddition d'Al-Bashir. ${ }^{29} \mathrm{Si}$ la critique envers la CPI est compréhensible dans une certaine mesure, on ne doit pas ignorer qu'il y a plusieurs raisons pour lesquelles la cour s'intéresse jusqu'ici principalement à l'Afrique. Ces raisons ont été expliquées ailleurs. ${ }^{30} \mathrm{Il}$ suffit ici de nommer trois des pays concernés (RCA, RDC et l'Ouganda) qui ont par eux-mêmes renvoyé des affaires dans leurs pays respectifs devant la CPI. De plus, la Côte d'Ivoire - un état non membre - a accepté la juridiction de la CPI en vertu de l'article 12(3) du statut de Rome. Pour finir, l'utilisation du pouvoir proprio motu du procureur selon

\footnotetext{
26 Voir le <www.icc-cpi.int/Menus/ICC/Situations+and+Cases/> consulté le 8 juillet 2012. Naturellement, les enquêtes préliminaires se rapportent actuellement aussi aux pays non-Africains, c.-à-d., l'Afghanistan, le Honduras, la Corée, le Nigéria, la Colombie, la Géorgie et la Guinée, voir ICC Office of the Prosecutor, 'Weekly Briefing', Issue 119 (24 April - 1 May 2012) p. $2<$ http://www.icccpi.int/NR/rdonlyres/C9C3544A-6558-461A-8FA3-

D38F2C5FA4A5/284506/OTPWeeklyBriefing24April1May2012.pdf> consulté le 11 juin 2012.

${ }^{27}$ Voir <www.icc-cpi.int/Menus/ASP/states+parties/> consulté le 8 juillet 2012.

28 Voir pour une analyse Kai Ambos, 'Expanding the Focus of the "AfricanCriminal Court", dans Yvonne McDermott, Niamh Hayes et William A Schabas (eds), Ashgate Research Companion Interational Criminal Law: Critical Perspectives (Ashgate, 2012), prochainement, disponible sur <http://papers.ssrn.com/sol3/papers.cfm?abstract_id=2017537> consulté le 14 juin 2012.

${ }^{29}$ African Union Assembly, Decision on the Meeting of African States Parties to the Rome Statute of the International Criminal Court (ICC), (3 July 2009) Assembly/AU/Dec.245 (XIII) Rev. 1 Doc. Assembly/AU/13(XIII), p. 2. Voiré galement African Union Press Release, 'On the decisions of PreTrial Chamber I of the International Criminal Court (ICC) Pursuant to Article 87(7) of the Rome Statute on the Alleged Failure by the Republic of Chad and the Republic of Malawi to Comply with the Cooperation Requests issued by the Court with respect to the Arrest and Surrender of President Omar Hassan Al Bashir of the Republic of the Sudan' (9 January 2012) Press Release No 002/2012.

${ }^{30}$ Voir Ambos (n 28).
} 
l'article 15 dans la situation au Kenya a été négociée à l'avance. Néanmoins, il est clair que l'élargissement général de la portée de la CPI rende nécessaire que, dans un avenir proche, elle puisse également ouvrir des enquêtes sur des situations en dehors de l'Afrique.

\section{II.}

La première réunion des experts africains à Bruxelles, visée ci-dessus, a eu comme thème général Pouvoir et poursuite: Défis et opportunités pour la justice pénale internationale en Afrique sub-saharienne. Le thème a été discuté sous diverses perspectives et différents points d'intérêt. Ainsi, le lecteur trouvera des essais sous forme d'études de pays sur des développements législatifs nationaux africains particuliers concernant l'incorporation du statut de Rome dans la loi domestique (par exemple: L'Afrique du Sud, le Rwanda, le Kenya, la RDC), et aussi, déconnecté du développements de pays africains spécifiques, des évaluations de divers sujets pertinents pour le développement de la justice pénale internationale en Afrique, telle que les influences de l'union africaine dans l'application domestique du statut de Rome et la poursuite de crimes sexuels dans des contextes africains. Etant donné la composition bilingue du groupe, le livre contient un document en anglais et un document en français. Tous les documents contiennent un résumé en anglais et en français.

\section{III.}

L'article de Max du Plessis (Institute for Security Studies \& Université d'Afrique du Sud de KwaZulu-Natal) intitulé 'Application du statut de RomeenAfrique du sud' présente une évaluation de la législation de l'Afrique du Sud domestiquant le statut de Rome. La loi d'application en Afrique du Sud du statut de Rome de la CPI a été promulguée en août 2002. Du Plessis explique et analyse les dispositions principales de la loi. Entre autres questions, il s'intéresse aux immunités et examine les dispositions sud-africaines. Il argue du fait que la loi permet à l'Afrique du Sud d'être conforme à ses engagements dérivant du statut de Rome et forme une base temporaire appropriée pour répondre aux demandes globales de la justice criminelle pour des crimes internationaux. Toutefois, il note, que le succès de la législation dépend de la volonté politique nationale, d'appliquer le cadre juridique nouvellement créé en Afrique du Sud.

Gerhard Kemp (Université de Stellenbosch, Afrique du Sud), dans sa contribution intitulée 'Mise en œuvre des amendements au Statut de Rome à l'égard du crime d'agression au niveau national: Un point de vue sud-africain', aborde la mise en œuvre du crime d'agression en Afrique du Sud. Kemp analyse les implications de l'adoption du crime de l'agression à la Conférence de révision du 
Statut de Rome de la CPI à Kampala en $2010^{31}$ pour la loi domestique de l'Afrique du Sud. La Loi de la CPI sud-africaine considère l'agression comme un crime international, et prévoit l'application du droit international. Dans ce contexte, l'auteur explore la signification et la valeur interprétative de la décision de Kampala, particulièrement pour la loi sud-africaine. Il plaide en faveur de la poursuite des crimes d'agression au niveau domestique.

Christian Garuka Nsabimana (avocat, Rwanda) offre un compte-rendu sur le Rwanda et la CPI avec son article 'Le Rwanda et la CPI : un besoin de ratification du statut de Rome'. Il précise que le Rwanda, malgré le fait qu'il soit parmi les quelques pays africains à avoir une expérience de la poursuite des crimes internationaux et à avoir un certain nombre de ressortissants poursuivis par un tribunal pénal international, n’a pas ratifié le statut de Rome. Il montre des développements pertinents au Rwanda et présente des arguments pour et contre la ratification. Tout en plaidant pour le besoin de ratifier le statut de Rome, il analyse les implications politiques et légales.

Lievin Ngombe (Association 'Culture pour la liberté et la justice', République démocratique du Congo), dans son article intitulé 'L'impact de la peine de mort dans le processus de l'adoption de la loi de mise en ouvre du statut de Rome en République Démocratique du Congo', s'intéresse aux développement concernant la mise en oeuvre du statut de Rome en RDC, et plus particulièrement à l'application de la peine du mort dans le pays. La RDC a ratifié le statut de Rome et a renvoyé une situation devant la CPI. Cependant, le statut de Rome n'a pas encore été mis en application dans la loi domestique. L'article évalue le débat en RDC sur la peine de mort et ses implications pour la mise en œuvre du statut de Rome dans la loi domestique. L'auteur identifie certaines contradictions à cet égard entre les lois de la RDC le droit pénal international.

Christopher Gevers (université de KwaZulu-Natal, Afrique du Sud) offreavec son article 'Immunité et la législation de mise en oeuvre en Afrique du Sud, au Kenya et en Ouganda' une étude comparative sur la question litigieuse des immunités. En guise d'introduction, il discute les diverses formes d'immunité, leur histoire, leur identification en vertu du droit international coutumier et ses développements relatifs. Il poursuit avec une évaluation des dispositions du statut de Rome sur l'immunité, particulièrement les articles 27 et 98 . Pour l'auteur, les deux dispositions doivent être lues séparément: Tandis que l'article 27 (2) garantit seulement l'exclusion de la défense d'immunité en vertu de la juridiction de la cour, l'article 98 (1) concerne la 'demande de remise ou d'assistance' c.-à-d. est plus lié au régime de coopération. Dans la partie comparative, l’article s'intéresse aux immunités pour des crimes internationaux en vertu des lois kényanes, ougandaises et sudafricaines, examinant deux questions en particulier: d'abord, dans quelle mesure les immunités peuvent justifier la non-coopération avec la CPI en ce qui concerne, par

31 Ci-joint, cf. Kai Ambos, 'The Crime of Aggression after Kampala' (2010) 53 German Yearbook of International Law 463-509. 
exemple, les potentielles extraditions (une question d'importance pratique considérable étant donné les mandats d'arrêt si controversés contre le Président soudanais Al-Bashir); et en second lieu, comment les immunités sont applicables aux poursuites domestiques en vertu des dispositions nationales respectives. L'auteur se concentre sur les incertitudes légales, particulièrement concernant la loi internationale et domestique coutumière, et l'applicabilité du droit international (coutumier) dans le contexte africain. En conclusion, il déplore l'ampleur de l'incertitude légale au niveau international et national, et les États parties africains adhérant au statut de Rome sont invités à clarifier leur position quant à l'immunité.

Evelyne Owiye Asaala (université nazaréenne d'Afrique, Kenya) dans son d'article 'Le facteur de la cour pénale internationale sur la justice transitoire au Kenya' analyse l'impact de la CPI sur la justice transitoire environnant le processus au Kenya au lendemain des violences post-électorales de 2007/08. Un ordre du jour kenyan pour résoudre les problèmes de violence développés par le 'Comité national de dialogue et de réconciliation du Kenya' (KNDRC) inclut des réformes constitutionnelles, l'établissement d'une commission vérité, et des poursuites. Avec la 'loi sur les crimes internationaux', le Kenya a incorporé le statut de Rome à sa loi nationale en 2008. La contribution analyse l'impact des enquêtes de la CPI sur la situation kényane et sur la législation nationale de mise en œuvre, tout en tenant compte du principe de complémentarité. L'approche du gouvernement kényan concernant la complémentarité est critiquée et la CPI est identifiée comme 'centrale' dans l'élaboration de la justice transitoire au Kenya. L'auteur considère que la participation de la CPI aura un impact de grande envergure au Kenya au niveau social, légal et politique, et argue du fait que les perceptions de la justice ont changé grâce aux investigations de la CPI.

Bonita Meyersfeld (Faculté de droit de Witwatersrand Centre d'études de droit appliqué, Afrique du Sud) dans son compte-rendu sur la 'Mise en application du statut de Rome en Afrique : Le potentiel et les problèmes des poursuites des crimes sexuels en Afrique selon le statut de Rome' explore les opportunités et les défis de la poursuite des crimes sexuels en Afrique selon le statut de la CPI. ${ }^{32}$ Dans le contexte d'un intérêt croissante pour les crimes et violences à caractère sexuel (CVCS) dans les situations où les crimes d'une dimension internationale sont perpétrés, sa contribution donne une vue d'ensemble historique des poursuites spécifiques de crimes de guerre, identifie les types d'agressions que les femmes subissent souvent pendant un conflit et étudie les insuffisances des poursuites après les conflits. Quant au dernier point, elle couvre certains problèmes conceptuels, les activités d'investigation probables et les structures organisationnelles dans les parquets respectifs (par exemple l'aide à la protection des témoins,

\footnotetext{
32 Sur la loi substantive et procedural ainsi que la pratique des crimes sexuels et leur pour suite voirré cemment Morten Bergsmo (ed), Thematic Prosecution on International Sex Crimes (Torkel Opsahl Academic EPublisher 2012); et Morten Bergsmo, Alf Butenschøn Skre, Elisabeth J. Wood (eds), Understanding and Proving International Sex Crimes (Torkel Opsahl Academic EPublisher 2012) (les deux sont disponibles sur < http://www.fichl.org/publication-series/> consulté le 9 juillet 2012).
} 
et la diffusion élargie des procédures pertinentes). Souscrivant à une poursuite accrue des crimes sexuels internationaux, le potentiel d'un tel développement est envisagé. Il est affirmé, que la poursuite des crimes à caractère sexuel offre des possibilités de réparation aux victimes qui sont souvent des femmes en jugeant le malfaiteur responsable. Elle argue d'autre part du fait que de telles poursuites peuvent engendrer un effet de dissuasion, d'une manière qui rende la poursuite des crimes CVCS importante non seulement pour les différentes affaires mais également pour la sécurité générale à venir des femmes dans les sociétés transitoires.

Dernier contributeur et non des moindres, Hendrik Johannes Lubbe (University of the North West, Afrique du Sud), écrit au sujet des 'Décisions de l'union africaine sur les mises en accusation d'Al-Bashir et de Kadhafi et leurs implications pour la mise en œuvre du statut de Rome par les États africains'. Il offre un examen critique des décisions de l'union africaine sur la CPI. Il étudie la teneur des décisions et de certaines des motivations de fond (telles que l'inactivité du Conseil de sécurité de l'ONU suivant une demande de l'union africaine conformément à l'article 16 du statut de Rome de renvoyer la situation du Darfour et les immunités personnelles des chefs d'Etat en exercice). À cet égard, les articles 27 (2) et 98 (1) du statut de Rome sont étudiés tout en arguant du fait qu'ils devraient être lus ensemble d'une manière complémentaire. L'auteur voit un conflit entre les décisions de l'union africaine et le droit international coutumier du statut de Rome. Il soulève des inquiétudes en ce qui concerne le fait que quelques États africains ont déjà adhéré à la décision, tout en ignorant illégalement leurs engagements pris dérivant du statut de Rome. De plus, il voit le risque que les États africains puissent suivre la décision de l'union africaine et refusent de ratifier et/ou de mettre en application le statut de Rome.

\section{IV.}

Quant à la composition et à la diffusion du groupe, le but est d'élargir la représentation régionale et de consolider davantage l'adhésion

En 2012, le groupe se réunira à Nairobi, au Kenya pour traiter de sujets entourant le 'Potentiel pour la poursuite domestique des crimes internationaux en Afrique'. Les thèmes pour de futures réunions abondent étant donné les multiples facettes de la pratique légale et politique africaine concernant la justice pénale internationale en général et la PCI en particulier. Le groupe devrait surveiller en particulier les développements récents en matière de justice pénale internationale ou transnationale au niveau africain régional. Quant aux développements nationaux, il est par exemple intéressant de mentionner qu'en Ouganda les demandes d'amnistie sur la base de la loi d'amnistie générale de 2000 ne sont plus honorées depuis le 23 mai 2003.33 Après la guerre civile entre le gouvernement de l'Ouganda et l'armée

\footnotetext{
33 Ugandan Minister of Internal Affairs, Statutory Instrument No. 34 of 2012 (23 May 2012), et Ugandan Minister of Internal Affairs, Statutory Instrument No. 35 of 2012 (23 May 2012) (tous les
} 
de résistance du seigneur, cette amnistie générale a servi à empêcher les poursuites nationales pour des crimes internationaux, ${ }^{34}$ bien qu'en 2008 en Ouganda une Division de crimes internationale ait été créée dans la haute cour afin de commencer de tels procès. ${ }^{35}$ Etant donné la fin de l'application de l'amnistie, les procès domestiques sont devenus plus réalisables.

Au niveau régional, il y a eu une tentative renouvelée d'établir la juridiction pénale africaine supranationale, qui devrait être étroitement surveillée. D’une part, l'Assemblée législative africaine a l'intention d'étendre la juridiction de la Cour de Justice de l'Afrique de l'Est (EACJ) ${ }^{36}$ aux poursuites de crimes internationaux; ${ }^{37}$ d'autre part, l'union africaine veut équiper la Cour africaine de Justice et des droits de l'homme d'une juridiction sur, entre autres, les crimes de génocide, les crimes de guerre et les crimes contre l'humanité. ${ }^{38}$

Si un tel mouvement vers la justice pénale régionale doit, en principe, être bien accueilli, les circonstances et les motifs concrets de certains États africains sont préoccupants. Clairement, les systèmes de justice pénale nationaux et régionaux doivent être renforcés puisque les états où ces crimes se produisent doivent princi-

deuxsur le fichier de l'auteur). Voiré galement, Justice Law and Order Sector (JLOS), 'The Statue of Amnesty in Uganda (Part 2)' (11 June 2012)

$<$ http:/ / www.jlos.go.ug/page.php?p=curnews\&id $=89>$ consulté le 5 Juillet 2012.

${ }^{34}$ JLOS 'The Amnesty Law (2000) Issues Paper - Review by the Transitional Justice Working Group' (April 2012) <www.jlos.go.ug/uploads/JLOS-

mnesty $\% 20$ Issues\%20Paper\%20\%5Bpublic\%20report\%5D.pdf> consulté le 9 Juillet 2012.

35 Judiciary of the Republic of Uganda, "The establishment of the International Crimes Division of the High Court'

$<$ http:/ / www.judicature.go.ug/index.php?option=com_content\&task=view\&id=117\&Itemid=154> consulté le 5 Juillet 2012.

36 Pour le site Web de l'EACJ, voir < http://www.eacj.org/> consulté le 11 juin 2012. L'EACJ est une institution juridique fondé sur le traité, voir le Traité pour l'établissement de la communauté de l'Africaine de l'Est, 1999, modifié lieu le 20 août 2007, arts 28 et suiv.

${ }^{37}$ East African Community, East African Legislative Assembly, 'Resolution of the Assembly seeking the EAC Council of Ministers to implore the International Criminal Court to transfer the case of the accused four Kenyans facing trial in respect of the aftermath of the 2007 Kenya general elections to the East African Court of Justice and to reinforce the treaty provisions' (26 April 2012) $<$ http://www.eala.org/oldsite041111/key-documents/doc_details/80-resolution-urging-the-eacpartner-states-to-halt-the-signing-of-the-eu-eac-epas.html>consulté le 11 juin 2012.

38 African Union, Meeting of Government Experts and Ministers of Justice/Attorneys General, 'Press Release No 037/2012' (14 May 2012) <www.au.int/en/dp/legal/content/meetinggovernment-experts-and-ministers-justiceattoreys-general>consulté le 14 juin 2012.Voiririn news, 'Analysis: How close is an Africa criminal court?' (13 June 2012) Johannesburg <www.irinnews.or/Report/95633/Analysis-How-close-is-a-African-criminal-court>consulté le 14 juin 2012 ('Plans for an African criminal court moved into an advanced stage with a final draft protocol drawn up in the Ethiopian capital Addis Ababa on 15 May. It is widely expected to be adopted at an AU summit meeting of heads of state in July'). Pour un compte-rendu, voir Chacha Bhoke Murungu, 'Towards a Criminal Chamber in the African Court of Justice and Human Rights' (2011) 2 Journal of International Criminal Justice 1067. 
palement les prendre en charge. Ceci correspond également à l'idée de complémentarité positive promue par les états parties à la CPI et le procureur de la CPI. ${ }^{39}$

Cependant de tels mouvements doivent être considérés avec un œil critique, s'ils servent à empêcher ou retarder l'application d'une justice véritablement indépendante et plutôt que d'être motivés par des investigations sur des événements concrets et des poursuites de personnes concrètes. C'est apparemment le cas en ce qui concerne l'idée d'une Cour de Justice de l'Afrique de l'Est, qui a été motivée par les enquêtes de la CPI sur les violences post-électorales au Kenya et les mandats d'arrêt contre quatre suspects kenyans. ${ }^{40}$ Ainsi, l'Assemblée législative d'Afrique de l'Est a fait la déclaration suivante :

Cette chambre décide [...] (que) le Conseil de Ministres s'engage immédiatement dans le processus de demande le transfert des procédures pour les quatre suspects accusés pour des faits liés aux violences post-électorales en 2007 de la cour pénale internationale et en les instruisant devant la Cour de Justice d'Afrique de l'Est sur la base que les actes pour lesquels ils sont poursuivis sont des contraventions du Traité. ${ }^{41}$

Clairement, une telle motivation montre plutôt une certaine réticence par les états concernés à rendre la justice plutôt qu'un intérêt réel à faire comparaitre les malfaiteurs responsables devant la justice. En fait, ce n'est pas exagérer que de suspecter que les procès devant une cour régionale ne soient 'tenus [...] que dans le seul but de protéger' les personnes responsables de leur responsabilité et justice pénale. ${ }^{42}$

\section{V.}

Comme toujours, cette publication a, indépendamment des auteurs mentionnés cidessus, différents mères et pères. Tout d'abord, Ottilia Anna Maunganidze de la Division pénale internationale et des menaces transnationales de l'institut des études de sécurité a fait un grand travail comme coordonnateur unique de facto du

\footnotetext{
39 Selon les mots de la CPI-BdP, la complémentarité positive désigne 'proactive policy of cooperation aimed at promoting national proceedings', voir ICC/Office of the Prosecutor, 'Prosecutorial Strategy 2009 - 2012' (1 February 2010), p. 5. Voir pour un compte-rendudétaillé William W. Burke-White, 'Implementing a Policy of Positive Complementarity in the Rome System of Justice' (2008) 19 Criminal Law Forum (CLF) 59 ff.; William W. Burke-White, 'Reframing positive complementarity', in Carsten Stahn/Mohamed M. El Zeidy (eds), The International Criminal Court and Complementarity - From Theory to Practice, Volume I, pp. 342 ff.; Carsten Stahn, 'Complementarity: A Tale of Two Notions' (2008) 19 CLF 87, 100 ff.; Morten Bergsmo/Olympia Bekou/Annika Jones, 'New Technologies in Criminal Justice for Core International Crimes: The ICC Legal Tools Project' (2010) 10 Human Rights Law Review 715, 723 ff.

${ }^{40}$ Voir le nom de la résolution (n 37) exigeant 'to implore the International Criminal Court to transfer the case of the accused four Kenyans facing trial in respect of the aftermath of the 2007 Kenya general elections to the East African Court of Justice [...]'.

${ }^{41}$ East African Legislative Assembly (26 april 2012) (n 37), para. 4.

${ }^{42}$ Cf. Article 17(2)(a) Statut de la CPI.
} 
groupe pour recueillir les avant-projets, les réviser avec grande précision et demander aux auteurs des corrections. De notre côté, Sabine Klein, chercheur dans mon département, candidat doctoral à Göttingen et avocat, l'a assistée. L'étudiante assistant chercheur Annika Poschadel a aidé pour la correspondance française. Ma secrétaire Anett Müller s'est assuré que l'éditeur d'université reçoive le manuscrit correctement formaté. Enfin et surtout, Andrea E. Ostheimer, directeur de programme du MDPD au bureau KAS de Bruxelles a élaboré l'idée d'un groupe d'étude expert africain, a mis en place le financement, organisé la traduction des résumés et était toujours disponible en cas d'urgence. C'est la première publication du tout jeune Groupe d'étude expert africain sur le droit pénal international. Nous espérons qu'il y a plus à venir avec une amélioration régulière de la qualité et de couverture régionale.

Kai Ambos

Göttingen, juillet 2012 



\title{
South Africa's implementation of the Rome Statute
}

\author{
Max du Plessis*
}

\begin{abstract}
South Africa is one of a handful of African states parties to domesticate the Rome Statute. This it achieved by passing the Implementation of the Rome Statute of the International Criminal Court Act 27 of 2002 (the ICC Act). A schedule appended to the ICC Act incorporates the crimes of genocide, war crimes and crimes against humanity, as defined by the Rome Statue, directly into South African law. The ICC Act gives South African courts jurisdiction over such crimes in certain circumstances and gives effect to South Africa's obligations under the complementarity scheme by creating the structures necessary for national prosecutions and empowering courts to prosecute perpetrators of ICC crimes within the Republic. The general principles of international criminal law applicable to the prosecution of ICC crimes are applicable before a South African court.
\end{abstract}

The ICC Act is premised on the fact that the International Criminal Court must rely, in most circumstances, on the intercession of states parties to gain custody of suspects, and mechanisms provided for in the Act allow South African authorities to fulfil this obligation. Furthermore, the ICC Act addresses the requirement laid out in the Rome Statute that states parties assist the ICC by cooperating in terms of investigating, prosecuting and enforcing sentences. The Act thus ensures that South Africa complies with its obligations as a State Party to the Rome Statute of the International Criminal Court.

Even so, the extent to which high-ranking officials, including servings heads of state or other senior government officials, suspected of having committed international crimes can claim immunity on the basis of their official status remains contentious. Section 4(2)(a) of the ICC Act effectively allows the South African legislature the choice whether or not to uphold high-ranking officials' immunity, but where it does so, South Africa must allow the ICC to exercise jurisdiction over the accused. 
Max du Plessis

The conclusion advanced is that the Act suitably foments South Africa's support of the International Criminal Court system, and demonstrates that the country is responding to the world public's demand for a stand on genocide, crimes against bumanity, and war crimes. The author notes, however, that the Act's ultimate success lies not in the strength of its internal provisions, but on the external will of the Government to use the Act to full effect against international criminals.

\section{La Mise en œuvre du Statut de Rome en Afrique du Sud}

\section{Résumé}

L'Afrique du Sud fait partie d'une poignée d'États parties africains à domestiquer le statut de Rome. Ce qu'il a réalisé en faisant voter la loi sur l'application du statut de Rome de la cour Pénale Internationale de 2002 (la Loi CPI).Un document annexé à la loi CPI incorpore les crimes de génocide, les crimes de guerre et les crimes contre l'bumanité, tels que définis par le statut de Rome, directement dans la loi sud-africaine. La loi CPI donne juridiction aux tribunaux sudafricains pour ces crimes dans certaines circonstances et donne suite aux engagements de l'Afrique du Sud sous des dispositions complémentaires en créant les structures nécessaires pour des poursuites nationales et en permettant aux tribunaux de poursuivre des responsables de crimes relevant de la CPI dans la République. Les principes généraux du droit pénal international applicables à la poursuite de crimes relevant de la CPI sont applicables devant un tribunal sud-africain.

La loi CPI se fonde sur le fait que la cour pénale internationale doit compter, dans la plupart des cas, sur l'intervention des États parties pour mettre les suspects en détention, et les mécanismes prévus dans la loi permettent aux autorités sud-africaines de respecter cet engagement. De plus, la loi CPI répond à l'obligation stipulée dans le statut de Rome selon laquelle les états parties assistent la CPI en coopérant en termes d'enquêtes, de poursuites et d'application des peines prononcées. La loi assure que l'Afrique du Sud est conforme à ses engagements comme Etat partie au statut de Rome de la cour pénale internationale.

Néanmoins, la mesure dans laquelle les fonctionnaires du haut rang, y compris les chefs d'Etat en fonction ou d'autres hauts fonctionnaires du gouvernement, suspectés d'avoir commis des crimes internationaux peuvent demander l'immunité sur la base de leurs positions officielles demeure sujet de controverses. La section 4 (2) (a) de la Loi CPI permet effectivement à la législature sud-africaine de choisir si l'immunité des hauts fonctionnaires doit être maintenue, mais lorsqu'elle l'est, l'A frique du Sud doit permettre à la CPI d'exercer sa juridiction sur l'accusé.

La conclusion avancée est que la loi favorise convenablement l'appui de l'Afrique du Sud au système de la cour pénale international, et démontre que le pays répond à la demande générale du monde de prendre position sur le génocide, les crimes contre l'bumanité, et les crimes de guerre. L'auteur note, cependant, que le succès final de la loi se situe non pas dans la force de ses disposi- 
tions internes, mais dans la volonté externe du gouvernement d'utiliser complètement cette loi contre les criminels internationaux.

\section{Introduction}

In order to give effect to its complementarity obligations under the Rome Statute, South Africa incorporated the Rome Statute into its domestic law by means of The Implementation of the Rome Statute of the International Criminal Court Act 27 of 2002 (the ICC Act). ${ }^{1}$ Prior to the ICC Act, South Africa had no municipal legislation on the subject of war crimes or crimes against humanity, ${ }^{2}$ and no domestic prosecutions of international crimes had taken place in South Africa.

Under the ICC Act, a structure is created for national prosecution of crimes in the Rome Statute. The Act takes seriously the 'complementary' obligation on South African courts to domestically investigate and prosecute the ICC offences of crimes against humanity, war crimes and genocide. The preamble, for instance, speaks of South Africa's commitment to bring 'persons who commit such atrocities to justice [...] in a court of law of the Republic in terms of its domestic law where possible'. And s 3 of the Act defines as one of its objects the enabling,

as far as possible and in accordance with the principle of complementarity, the national prosecuting authority of the Republic to adjudicate in cases brought against any person accused of having committed a crime in the Republic and beyond the borders of the Republic in certain circumstances.

\footnotetext{
* This article draws heavily from my chapter 'International Criminal Law, The International Criminal Court, and South Africa's Implementation of the Rome Statute' in John Dugard (ed), International Law - A South African Perspective (Juta 2011).

1 The Implementation of the Rome Statute of the International Criminal Court Act 27 of 2002 (ICC Act 2002). The full text of the Act is available at <http://www.info.gov.za/acts/2002/a27-02/> accessed 20 June 2012. The ICC Act came into force on 16 August 2002. For further information on the Act, see M du Plessis, 'Bringing the International Criminal Court Home: The Implementation of the Rome Statute of the International Criminal Court Act' (2003) 16 South African Journal of Criminal Justice 1.

2 Although customary international law forms part of South African law, a South African court confronted with the prosecution of a person accused of an international crime would have been hard pressed to convict, since the principle of nullum crimen sine lege would probably have constituted a bar to any such prosecution. The same principle would most likely have also put paid to prosecutions under the Geneva Conventions of 1949. South Africa has not incorporated the Geneva Conventions into municipal law nor, prior to the ICC Act, enacted legislation to punish grave breaches. It would therefore have been unlikely for a South African court to try a person for a grave breach of the Conventions in the absence of domestic legislation penalising such conduct. This proposition was challenged before the South African Constitutional Court in Sv Basson (2005) 12 BCLR 1192 (CC). However, the court found it unnecessary 'to consider whether customary international law could be used $[\ldots]$ as the basis in itself for a prosecution under the common law' (para 172, n 147).
} 
Like the Rome Statute, the ICC Act does not reach back into the past. The Act provides expressly that ' $[\mathrm{n}] \mathrm{o}$ prosecution may be instituted against a person accused of having committed a crime if the crime in question is alleged to have been committed before the commencement of the Statute'. ${ }^{3}$

\section{Incorporation of ICC crimes}

The advantage of the Rome Statute of the International Criminal Court is that it brings together in one place a codified statement of the elements which make up the crimes of genocide, war crimes, and crimes against humanity. The drafters of the ICC Act, aware of this benefit of codification, incorporated the ICC Statute's definitions of the core crimes directly into South African law through a schedule appended to the Act. In this regard, P 1 of Schedule 1 to the ICC Act follows the wording of art 6 of the ICC Statute in relation to genocide; P 2 of the Schedule mirrors art 7 of the Statute in respect of crimes against humanity; and P 3 does the same for war crimes, as set out in art 8 of the ICC Statute. It is clear that these crimes now form part of South African law through the Act. One of the objects of the Act is 'to provide for the crime of genocide, crimes against humanity and war crimes', ${ }^{4}$ and s 4(1) of the Act provides that '[d] espite anything to the contrary in any other law in the Republic, any person who commits a crime [defined as genocide, crimes against humanity and war crimes], is guilty of an offence'. The ICC Act, at this stage, requires amendment in order to provide for the definition and jurisdictional regime for the crime of aggression following the Kampala amendment discussed earlier.

While the Act usefully incorporates the definitions of these crimes into South African domestic law, neither the ICC Act nor Schedule 1 refers specifically to art 9 of the Rome Statute on Elements of Crimes. ${ }^{5}$ There is nothing, however, that prevents a South African court from having regard to the Elements of Crimes, were it to be involved in the domestic prosecution of an ICC offence. However, in the interests of clarity and completeness, it is suggested that South Africa follow the example of other states parties ${ }^{6}$ and incorporate, by regulation, the Elements of Crimes. ${ }^{7}$

\footnotetext{
${ }^{3}$ ICC Act 2002, s 5 (2).

${ }^{4}$ Ibid s 3(c).

${ }^{5}$ For the purposes of interpreting and applying the definitions of crimes found in arts 6,7 and 8 of the Rome Statute, reference must also be made to the 'Elements of Crimes', a 50-page document adopted in June 2000 by the Preparatory Commission for the International Criminal Court. See the 'Finalized Draft Text of the Elements of Crimes' (PCNICC/2000/INF/3/Add.2).

${ }^{6}$ For example, the Secretary of State in the United Kingdom has, by regulation, made the Elements of Crimes applicable to proceedings in a service court within the United Kingdom. See 'The International Criminal Court Act 2001 (Elements of Crimes) Regulations 2001'

<http://www.hmso.gov.uk/si/si2001/20012505.htm> accessed 20 June 2012.

7 In terms of s 38 of the ICC Act 2002, the Minister of Justice may make regulations regarding the
} 


\section{Grounds of jurisdiction}

Section 4(1) of the ICC Act creates jurisdiction for a South African court over ICC crimes by providing that ' $[\mathrm{d}]$ espite anything to the contrary in any other law of the Republic, any person who commits [an ICC] crime, is guilty of an offence and liable on conviction to a fine or imprisonment'. Section 4(3) of the Act goes further and provides for extra-territorial jurisdiction. In terms of that section, the jurisdiction of a South African court will be triggered when a person commits an ICC crime outside the territory of the Republic and:

(a) that person is a South African citizen; or

(b) that person is not a South African citizen but is ordinarily resident in the Republic; or

(c) that person, after the commission of the crime, is present in the territory of the Republic; or

(d) that person has committed the said crime against a South African citizen or against a person who is ordinarily resident in the Republic.

When a person commits a core crime outside the territory of the Republic in one of these four circumstances, then s 4(3) deems that crime to have been committed in the territory of the Republic.

The jurisdictional 'triggers' in the ICC Act are largely uncontroversial. Section 4(1) appears to assert the traditional principle of territoriality; namely, that a state has competency in respect of all acts which occur in its territory. And s 4(3), which provides for extra-territoriality, begins in trigger (a) with the recognized nationality basis for jurisdiction. That is, international law has long accepted that states have the competency to exercise jurisdiction over their nationals for crimes committed anywhere in the world. Trigger (b) extends, in similar fashion, jurisdiction over South African residents on the basis that they have a close and substantial connection with South Africa at the time of the offence. Trigger (c) of the ICC Act extends jurisdiction to a person who, 'after the commission of the crime, is present in the territory of the Republic'. There is no mention here of the person's nationality or residency, and one must assume, given that triggers (a) and (b) already provide jurisdiction in respect of crimes committed abroad by South African nationals and residents, that trigger (c) is referring to individuals who commit a core crime and who do not have a close and substantial connection with South Africa at the time of offence. ${ }^{8}$ The jurisdiction in trigger (c) is thus grounded in the idea of universal

ICC Act. In terms of s 1(xx) of the Act, such regulations would be included as part of the Act.

8 The UK's implementing legislation, for example, provides more clearly that, aside from the traditional bases of jurisdiction (territoriality and nationality), the UK courts will have jurisdiction over a person who 'commits acts outside the United Kingdom at a time when he is not a United Kingdom national, a United Kingdom resident or a person subject to UK service jurisdiction and who subsequently becomes resident in the United Kingdom' (see s 68(1) of the United Kingdom's International Criminal Court Act 2001 [UK ICC Act 2001]). 
jurisdiction; that is, jurisdiction which exists for all states in respect of certain crimes which attract universal jurisdiction by their egregious nature, and consequently over the perpetrators of such crimes on the basis that they are common enemies of mankind. This form of jurisdiction is to be welcomed as genocide, crimes against humanity, and war crimes are among the most serious crimes of concern to the international community as a whole, and as such, are often regarded as giving rise to 'universal jurisdiction'. ${ }^{9}$ Trigger $(d)$ is founded on the passive personality principle in international law. In terms of that principle a state has the competency to exercise jurisdiction over an individual who causes harm to one of its nationals abroad.

The ICC Act provides that a South African Court, charged with the prosecution of a person allegedly responsible for a core crime, shall apply 'the Constitution and the law'..$^{10}$ The South African Bill of Rights in s 35 sets out a range of rights for arrested, detained and accused persons. These protections will obviously need to be afforded to any person who is being tried under the ICC Act. In addition, the Rome Statute sets out a comprehensive framework of general principles of liability and defences in P 3 of the Statute. While the drafters of the ICC Act have not chosen to expressly adopt P 3, s 2 of the Act says that applicable law for any South African court hearing any matter arising under the Act includes 'conventional international law, and in particular the [Rome] Statute'. ${ }^{11}$ Accordingly, the general principles of international criminal law applicable to the prosecution of genocide, war crimes and crimes against humanity (including the available defences contained in the Rome Statute such as superior orders) ought to find application before a South African court.

\section{Complementarity}

The ICC Act gives effect to the complementarity scheme by creating the structure necessary for national prosecutions under the ICC Statute. The procedure for the institution of prosecutions in South African courts is set out in s 5 of the Act. This procedure involves different governmental departments and officials. First, the ICC Act requires that the consent of the National Director of Public Prosecutions must be obtained before any prosecution may be instituted against a person accused of having committed a crime. ${ }^{12}$ The National Director must, when reaching a decision about a prosecution, recognize South Africa's obligation, in the first instance, under the principle of complementarity in the Rome Statute, to exercise jurisdiction over and to prosecute persons accused of having committed an ICC

\footnotetext{
9 See, for example, A Cassese and others (eds), The Rome Statute of the International Criminal Court: A Commentary, vol 2 (OUP2002) 1862.

10 ICC Act 2002, s 2.

${ }^{11}$ Ibid s 2(a).

12 Ibid s 5(1).
} 
crime. ${ }^{13}$ Given the importance of any such prosecution, it is clear that a specialized court would need to be designated. The Act provides that, after the National Director has consented to a prosecution, an appropriate High Court must be designated for that purpose. Such designation must be provided in writing by the 'Cabinet member responsible for the administration of justice [...] in consultation with the Chief Justice of South Africa and after consultation with the National Director'. ${ }^{14}$ The ICC Act does not provide any specific trial procedure or punishment regime for domestic courts. All that the ICC Act provides is for the designation of 'an appropriate High Court in which to conduct a prosecution against any person accused of having committed [an ICC] crime'. ${ }^{15}$ Presumably the usual trial procedure for a criminal trial in the High Court will be followed and the High Court will be empowered to issue any of the sentences which it would ordinarily be entitled to impose in terms of its domestic criminal sentencing jurisdiction. Such punishments would include life imprisonment, imprisonment, a fine, and correctional supervision.

The expectation under the Act, flowing from South Africa's obligations under the complementarity scheme, is that a prosecution will take place within the Republic. Accordingly, if the National Director declines to prosecute a person under the Act, the Director-General for Justice and Constitutional Development must be provided with the full reasons for that decision. ${ }^{16}$ The Director-General is then obliged to forward the decision, together with reasons, to the Registrar of the International Criminal Court in The Hague. ${ }^{17}$

\section{Co-operation with the International Criminal Court}

\subsection{Arrest and Surrender}

The ICC Act is premised on the understanding that the International Criminal Court will in most circumstances have to rely on the intercession of national jurisdictions to gain custody of suspects. As a result the ICC Act envisages two types of arrest: one in terms of an existing warrant issued by the ICC, and another in terms of a warrant issued by South Africa's National Director of Prosecutions (NDPP). In both scenarios the warrant (whether endorsed or issued) must be in the form and executed in a manner as near as possible to that which exists in respect of warrants of arrest under existing South African law. ${ }^{18}$

Dealing with the first scenario (an arrest in terms of an existing warrant issued

\footnotetext{
${ }^{13} \operatorname{Ibid~s~5(3).~}$

${ }^{14} \operatorname{Ibid~s} 5(4)$.

${ }^{15}$ Ibid s 5(5).

16 Ibid.

17 Ibid.

${ }^{18}$ Ibid s 9(3).
} 
Max du Plessis

by the ICC), in terms of s 8 of the ICC Act, when South Africa receives a request from the ICC for the arrest and surrender of a person for whom the ICC has issued a warrant of arrest, it must refer the request to the Director-General of Justice and Constitutional Development with the necessary documentation to satisfy a local court that there are sufficient grounds for the surrender of the person to The Hague. ${ }^{19}$ The Director-General must then forward the request (along with the necessary documentation) to a magistrate who must endorse the ICC's warrant of arrest for execution in any part of the Republic. ${ }^{20}$

Section 9 details the second scenario (an arrest in terms of a warrant issued by the National Director of Prosecutions). In this situation the Director-General of Justice and Constitutional Development is mandated to receive a request from the ICC for the provisional arrest of a person who is suspected or accused of having committed a core crime, or has been convicted by the ICC. The Director-General is then obliged under the ICC Act to immediately forward the request to the $\mathrm{Na}$ tional Director of Public Prosecutions, who must then apply for the warrant before a magistrate. ${ }^{21}$

After being arrested pursuant to a warrant (whether that warrant was issued by the ICC or by the NDPP), the arrestee is to be brought 'before a magistrate in whose area of jurisdiction he or she has been arrested or detained"within 48 hours after that person's arrest or on the date specified in the warrant for his or her further detention'. ${ }^{22}$

Having laid their hands on the arrestee, the South African authorities then become engaged in what is known as the 'surrender' of an arrestee to the International Criminal Court --- his or her 'delivery' to The Hague. To make a committal order, with a view to the surrender of an arrestee to the International Criminal Court, the magistrate has to be satisfied of three things only. First, the magistrate must be satisfied that the person before court is the individual named in the warrant. ${ }^{23}$ Second, that the person has been arrested in accordance with the procedures set down by domestic law. ${ }^{24}$ And third, that the arrestee's rights, as contemplated in the Bill of Rights, have been respected, if, and to the extent to which, they are or may be applicable. ${ }^{25}$ The nature of these three requirements makes it clear that surrender to the ICC is different to extradition in international law. There is no mention of the double criminality rule which has become so central to extradition proceedings. And unlike many extradition proceedings, there is no requirement in the ICC Act that a prima facie case be shown against the suspect. Section 10(5) of the ICC Act provides as the primary test that, if, after considering

\footnotetext{
${ }^{19}$ Ibid s 8(1).

20 Ibid s 8(2).

21 Ibid s 9(1).

22 Ibid s $10(1)$

23 Ibid s 10(1)(a).

24 Ibid s 10(1)(b).

25 Ibid s 10(1)(c).
} 
the evidence adduced at the inquiry the magistrate is satisfied that the three requirements outlined above are met, then the magistrate 'must issue an order committing that person to prison pending his or her surrender to the Court'. Of course, the magistrate also has to be satisfied that the International Criminal Court has a genuine interest in the surrender of the arrestee, and to this end s 10(5) stipulates that, in addition to the three requirements being met, the magistrate must be content that the person concerned may be surrendered to the court: (a) for prosecution for the alleged crime; (b) for the imposition of a sentence by the court for the crime in respect of which the person has been convicted, or (c) to serve a sentence already imposed by the court. ${ }^{26}$ There is little indication in the Act what level of proof must be proffered by the prosecution in respect of these additional requirements, such as, whether the court must inquire whether there is evidence to justify his trial for the offence he is alleged to have committed. ${ }^{27}$ Presumably any of these three factual conditions will have been proved by the terms of the International Criminal Court's request, either for the endorsement of its own warrant of arrest within South Africa (in terms of s 8 of the ICC Act), or for South Africa to issue a provisional warrant of arrest pursuant to the court's request (in terms of s 9 of the ICC Act) such that these additional requirements may be regarded as being satisfied on the strength of the 'material supporting the request' for surrender provided by the International Criminal Court. ${ }^{28}$

\subsection{Forms of assistance offered to the court in fulfillment of art 93 of the Rome Statute}

Article 93 of the Rome Statute requires states parties to assist the ICC by cooperating in relation to investigations and prosecutions. Part 2 of the ICC Act sets out a variety of circumstances in which the relevant competent authorities in the Republic must 'cooperate with, and render assistance to, the Court in relation to investigations and prosecutions'. There are many areas of co-operation (detailed in s 14 of the Act), such as the questioning of suspects, the identification and whereabouts of persons or items, the taking of evidence (including expert opinions), inspections

\footnotetext{
${ }^{26}$ One must assume that the listing of these conditions is in the disjunctive.

${ }^{27}$ By contrast, the United Kingdom's ICC Act, for example, makes it clear that a court, when making an order for surrender, 'is not concerned to enquire' whether the warrant was duly issued by the ICC or, where the person to be surrendered is 'alleged to have committed an ICC crime, whether there is evidence to justify his trial for the offence he is alleged to have committed' (see UK ICC Act 2001, s 5(5); see, too, the commentary on the Act by Robert Cryer, 'Implementation of the International Criminal Court Statute in England and Wales' (2002) 51 ICLQ733, 736).

28 Article 89 of the Rome Statute, which deals with surrender of persons to the court, provides that the 'court may transmit a request for the arrest and surrender of a person, together with the material supporting the request' to a state party, so this material would be before the magistrate. Prior to this, to obtain a warrant of arrest from the ICC, the Prosecutor would have had to convince a pre-trial chamber of the court (consisting of three judges) that there were 'reasonable grounds to believe' the suspect had committed an ICC offence.
} 
in loco (including the exhumation and examination of grave sites) and execution of searches and seizures, to name but a few. ${ }^{29}$ The areas of co-operation must be undertaken in terms of the relevant law applicable to investigations in South Afri$\mathrm{ca}$, as well as the applicable rules in the Rome Statute, ${ }^{30}$ and with the ultimate aim of assisting the ICC.

Certain acts of co-operation are subject to comprehensive regulation in the ICC Act, and others are not. For example in the context of questioning suspects, the ICC Act stipulates in s 14(c) no more than that the competent South African authorities must assist with 'the questioning of any person being investigated or prosecuted'. South African authorities will therefore have to turn to the Rome Statute and South African law for assistance. In this respect the Bill of Rights in s 35 and the Rome Statute in art 55 equally guarantee certain rights to a person under investigation, such as the right against self-incrimination, the right to remain silent, and the right to legal assistance.

Those means of co-operation that are subject to detailed regulation under the ICC Act include the examination of witnesses, ${ }^{31}$ the transfer of a prisoner to the ICC for the purposes of giving evidence or to assist in an investigation, ${ }^{32}$ the service of process and documents, ${ }^{33}$ acts of entry, search and seizure, ${ }^{34}$ and the making of forfeiture or confiscation orders..$^{35}$

\subsection{Discretionary measures of assistance}

In terms of the ICC Act, the President may, at the request of the ICC and by proclamation in the Government Gazette, declare any place in the Republic to be the seat

\footnotetext{
${ }^{29}$ The full list of areas of cooperation is set out in s 14(a)-(l). The list is modelled on art 93 of the Rome Statute.

${ }^{30}$ Section 14 reads that the 'relevant competent authorities in the Republic must, subject to the domestic law of the Republic and the Statute, cooperate with, and render assistance to, the Court' (emphasis added). The Constitution, where applicable, will no doubt provide the background standards against which the relevant 'cooperation' is undertaken. So, for example, when it comes to searches and seizures in terms of s 14(h), read with s 30 of the ICC Act 2002, the relevant provisions of the Act will need to be read in conjunction with ss 10,12(1)(a)-(d), 12(2)(b), 14, 21, 35(5) and 36(1) of the Constitution.

31 ICC Act 2002, ss 15, 16, 17, 18 and 19. The sections outline the procedure for the examination of witnesses before a magistrate, the rights and privileges of the witness, the offences which a witness might commit, and the procedure by which the attendance of a witness might be secured in proceedings before the International Criminal Court.

32 ICC Act 2002, s 20.

33 Ibid s 21.

${ }^{34} \mathrm{Ibid} \mathrm{s} 30$. This section is in many respects similar to those provisions of the Criminal Procedure Act 51 of 1977 in relation to search and seizure (ss 19-36), but with modifications to reflect the fact that the request for co-operation has been made by the ICC for the purposes of its investigation, and not to assist South Africa in criminal investigations unrelated to the ICC.

$35 \mathrm{Ibid}$ ss 14(k), 22(1) and 27(1). For fuller discussion, see M du Plessis, 'Bringing the International Criminal Court Home: The Implementation of the Rome Statute of the International Criminal Court Act' (2003) 16 South African Journal of Criminal Justice 1, 10-12.
} 
of the ICC. ${ }^{36}$ Should such a declaration be made, then the ICC Act sets out a variety of privileges and immunities for the court. First, the court is accorded such rights and privileges of a South African court of law in the Republic as may be necessary to enable it to perform its functions. ${ }^{37}$ Furthermore, the judges, the prosecutor, the deputy prosecutors and the registrar of the court, while performing their functions in the Republic, enjoy the same immunities and privileges that are accorded to a representative of another state or government in terms of s 4(2) of the South African Diplomatic Immunities and Privileges Act 37 of 2001.38 Those immunities include immunity from the criminal and civil jurisdiction of the courts of the Republic, and the privileges enjoyed are those which (a) a special envoy or representative enjoys in accordance with the rules of customary international law; or (b) are provided for in any agreement entered into with a state, government or organization whereby immunities and privileges are conferred upon such special envoy or representative.

The deputy registrar, the staff of the office of the prosecutor and the staff of the registry of the court enjoy the privileges and facilities necessary for the performance of their functions in the Republic as may be published by proclamation in the Government Gazette as provided for in s 7(2) of the Diplomatic Immunities and Privileges Act of 2001.39

The Minister of Foreign Affairs may, after consultation with the Minister of Justice, confer immunities and privileges on any other member of the staff of the court or any person performing functions for purposes of the ICC Act. Such immunities and privileges are conferred by the Minister of Foreign Affairs publishing a notice in the Government Gazette, on such conditions as he or she deems necessary. ${ }^{40}$ Any person who is accorded immunities or privileges in terms of the ICC Act must have his or her name entered into a register as contemplated in s 9(1) of the Diplomatic Immunities and Privileges Act 2001.41

\subsection{Enforcement of sentences}

The Rome Statute stresses that 'States Parties should share the responsibility for enforcing sentences of imprisonment, in accordance with principles of equitable distribution'. ${ }^{42}$ The International Criminal Court will have no prison, and States are therefore expected to volunteer their services, indicating their willingness to allow convicted prisoners to serve the sentence within their domestic penal institutions. ${ }^{43}$

\footnotetext{
36 ICC Act 2002, s 6.

37 Ibid s 7(1).

38 Ibid s $7(2)$.

39 Ibid s $7(3)$.

40 Ibid s 7(4).

41 Ibid s 7(5).

42 Rome Statute, art 103(3)(a) as well as Rule 201 of the Rules of Procedure and Evidence.

43 See, further, W A Schabas, An Introduction to the International Criminal Court (2004) 170. If no state
} 
After sentencing an offender, the ICC will, in terms of art 103(1)(a) of the Rome Statute, designate the state where the term is to be served. In so doing the Court must take into account the views of the sentenced prisoner, his or her nationality, and 'widely accepted international treaty standards governing the treatment of prisoners'. ${ }^{44}$ In addition, conditions of detention must be neither more nor less favourable than those available to prisoners convicted of similar offences in the state where the sentence is to be enforced. ${ }^{45}$

In order to give effect to this enforcement scheme, the ICC Act provides that the Minister of Correctional Services must consult with the Cabinet and seek the approval of Parliament with the aim of informing the ICC whether South Africa can be placed on the list of states willing to accept sentenced persons. ${ }^{46}$ If the Republic is placed on the list of states and is designated as a state in which an offender is to serve a prison sentence, then such person must be committed to prison in South Africa. ${ }^{47}$ The provisions of the Correctional Services Act $1998^{48}$ and South African domestic law then apply to that individual. However, the sentence of imprisonment may only be modified at the request of the ICC, after an appeal by the prisoner to, or review by, the Court in terms of the Rome Statute. ${ }^{49}$

It is commendable that the ICC Act requires the government to indicate its availability to assist in enforcing the ICC sentences. It is not clear however that South Africa will be placed on the list of states available for enforcement duty. The Rome Statute makes it clear that there can be 'no question of sending a prisoner to a State with prison conditions that do not meet international standards. ${ }^{50}$ This is a particular problem for South Africa, given the poor state of its prisons. ${ }^{51}$

The Rome Statute also enables the ICC to impose a fine, but only '[i]n addition to imprisonment'. 52 On top of this, the ICC is empowered to address the issue of reparations to victims, and may 'make an order directly against any convicted person' specifying reparation. ${ }^{53}$ Such an order will no doubt often take the form of monetary compensation. The ICC Act makes provision for the execution of such

offers its prison services, the host state of the ICC - the Netherlands - will perform the task (see Rome Statute, art 103(4)).

${ }^{44}$ ICC Act 2002, art 103(3).

$45 \mathrm{Ibid}$ art 106(2).

46 Ibid s 31.

${ }^{47}$ Ibid s 32 .

48 Act 111 of 1998.

${ }^{49}$ Section 32(4)(b). This provision is a reflection of the prescription in art 110(2) of the Rome Statute whereby the ICC 'alone shall have the right to decide any reduction of sentence'.

50 Schabas (n 43) 75.

51 The Judicial Inspectorate of Prisons reported at the end of 2000 that prisons were severely overcrowded, with some at 200 per cent occupancy rate, and that a third of the prison population awaiting trial was detained under inhumane conditions and in breach of national law and international standards. See, further, J Steinberg, Prison Overcrowding and the Constitutional Right to Adequate Accommodation in South Africa (CSVR Monograph 2005).

${ }^{52}$ ICC Act, art 77(2)(a).

${ }^{53} \mathrm{Ibid}$ art 75(2). 
fines and compensation orders within the Republic. ${ }^{54}$ Such orders must be registered with a court in the Republic having jurisdiction. ${ }^{55}$ Once the order has been registered, that sentence or order 'has the effect of a civil judgment of the court at which it has been registered', and the Director General of Justice and Constitutional Development must pay over to the ICC any amount realized in the execution of the sentence or the order, minus any expenses incurred by the Republic in the execution thereof. 56

\section{Specialised units}

In order that South Africa's obligations under the ICC Act may be fulfilled, a Priority Crimes Litigation Unit (PCLU) has been established within the National Prosecuting Authority, and which is headed by a Special Director of Public Prosecutions appointed in terms of s 13(1)(c) of the National Prosecuting Authority Act.Section 13(1)(c) provides that the President may appoint one or more Directors of Public Prosecutions (referred to as Special Directors) to perform functions assigned to him by the President by proclamation in the Gazette.

The Special Director's appointment was confirmed in terms of Government Gazette No 24876 of 23 May 2003.57 The Special Director was given two powers:first to head the Priority Crimes Litigation Unit; and, second, to 'manage and direct the prosecution of crimes contemplated in the Implementation of the Rome Statute of the International Criminal Court Act'. The Unit is thus specifically tasked with dealing with the ICC crimes set out in the ICC Act.

In practice the PCLU has expressed the view that when it comes to the investigation of the alleged perpetrator it is dependant on the cooperation of the South African Police Services. Recently a Directorate for Priority Crimes Investigation (DPCI) has been established within the Police, and the crimes under the ICC Act fall within its purview for investigation. In practice this means that requests by individuals or civil society groups for investigation and prosecution under the ICC Act should be directed jointly to the PCLU and DPCI.

On the assumption that the PCLU with the assistance of DPCI takes up the investigation and issues a warrant of arrest (in camera or otherwise) and the suspect or suspects are arrested, the matter will then move to the prosecution stage. The ICC Act stipulates that no prosecution may be instituted against a person accused of having committed a core crime without the consent of the National Director of Public Prosecutions. Assuming that such consent is provided, the matter will proceed to court and the PCLU will adopt responsibility for the prosecution of the matter.

\footnotetext{
${ }^{54}$ Ibid ss 25 and 26.

55 Ibid ss 25(2) and (3).

56 Ibid s 26.

${ }^{57}$ Proclamation No 43 of 2003.
} 


\section{$7 \quad$ Immunities}

While the ICC Act provides South African courts with potential jurisdiction over persons who may have committed ICC crimes, the issue of immunity from jurisdiction for high-ranking officials remains contentious. The most heated debate has been around the extent to which serving heads of state and other senior government officials can justifiably claim immunity, on the basis of their official status, from proceedings brought against them for allegedly committing international crimes.

Before the ICC matters are relatively clear. Article 27 of the Rome Statute provides that the 'official capacity as a head of state or government, a member of a government or parliament, an elected representative or a government official shall in no case exempt a person from criminal responsibility under this Statute.' The position of international law immunities before national courts is however less obvious. For instance, in the ground breaking Pinochet cases, the House of Lords accepted that serving international functionaries (such as current heads of state) retain absolute immunities rationae personae (ie, personal immunity on account of their status), irrespective of the nature of the crime alleged, unless waived by the sending state. The House of Lords denied immunity to Pinochet in his capacity as a former head of state. However, it made it clear that if he had still been an acting head of state, this immunity in international law would have continued to subsist. ${ }^{58}$ The International Court of Justice has affirmed this immunity in its decision in the Arrest Warrant Case. ${ }^{59}$ With regard to the provisions precluding immunity found in the constitutive instruments of a myriad of international criminal tribunals (the most recent being the Rome Statute of the ICC), the Court expressly held that this exception to customary international law was not applicable to national courts. ${ }^{60}$ This case law therefore suggests that the diplomatic or head of state immunity of an accused prevents national courts from dealing with allegations of international crimes unless that immunity has been waived, or the senior official has left office. This lack of clarity is particularly problematic in light of the fact that national courts of states parties to the Rome Statute are expected to act in a 'complementary' arrangement with the ICC, prosecuting individuals for ICC crimes and deferring to the ICC only where the national state is unwilling or unable to perform its prosecutorial role.

South Africa has attempted to cut its way past this controversy by providing in s 4(2)(a) of the ICC Act that notwithstanding

\footnotetext{
${ }^{58}$ For instance, Lord Nicholls in the first Pinochet case held that 'there can be no doubt that if Senator Pinochet had still been the head of the Chilean state, he would have been entitled to immunity' (see $R$ $v$ Bow St Magistrate, Ex p Pinochet Ugarte [1998] 4 All ER (Pinochet 1) 938). Lord Millett in the third Pinochet case said that 'Senator Pinochet is not a serving head of state. If he were, he could not be extradited. It would be an intolerable affront to the Republic of Chile to arrest him or detain him' (see R v Bow St Magistrate, Exp Pinochet (No 3) [1999] 2 WLR 824, 905H).

59 Arrest Warrant of 11 April 2000 (Democratic Republic of the Congo v. Belgium) 2002 ICJ Reports 3.

${ }^{60}$ Para 58.
} 
any other law to the contrary, including customary and conventional international law, the fact that a person [...] is or was a head of State or government, a member of a government or parliament, an elected representative or a government official [...] is neither --- (i) a defence to a crime; nor (ii) a ground for any possible reduction of sentence once a person has been convicted of a crime.

In terms of the Act, South African courts, acting under the complementarity scheme, are accorded the same power to 'trump' the immunities which usually attach to officials of government as the International Criminal Court is by virtue of art 27 of the Rome Statute.

As Dugard and Abraham have pointed out, s 4(2)(a) of the ICC Act represents a choice by the legislature wisely not to follow the 'unfortunate' Arrest W arrant decision (of which it must have been aware). ${ }^{61}$ Support for an argument that $\mathrm{s}$ 4(2)(a) of the ICC Act does indeed scrap immunity, notwithstanding the contrary position under customary international law, comes from the Constitution itself. Section 232 provides that '[c]ustomary international law is law in the Republic unless it is inconsistent with the Constitution or an Act of Parliament'.

But even were a South African official or court to decide to uphold a foreign official's immunity, under the complementarity scheme it will be expected of South Africa as a state party to the Rome Statute to ensure that the ICC is able to exercise jurisdiction over the accused. Any decision by the South African authorities not to prosecute entitles the ICC to do so in South Africa's place. Section 5(6) of the ICC Act says to this effect that a decision by the National Director 'not to prosecute a person under this section does not preclude the prosecution of that person in the [International Criminal] Court'. And art 98(1) of the Rome Statute entails that states parties have a duty of cooperation with the court, requiring such states to arrest and surrender to the court persons charged with an ICC crime. ${ }^{62}$

${ }^{61}$ See J Dugard and G Abraham, 'Public International Law' (2002) Annual Survey of South African Law 140, 166.

62 Such obligation, however, would only be incumbent upon a state where an official charged before its court is an official of a state that is also a party to the ICC Statute. That is because both states, as parties to the ICC Statute, have accepted that the constitutive instrument of the ICC has scrapped immunities for heads of state and other government officials through art 27. The position may well be different where the accused person is an official of a state not party to the Statute. Article 98(1) of the Rome Statute provides that

[t]he [International Criminal] Court may not proceed with a request for surrender or assistance which would require the requested State to act inconsistently with its obligations under international law with respect to the State or diplomatic immunity of a person or property of a third State, unless the Court can first obtain the cooperation of that third State for the waiver of the immunity.

If, under international law, personal immunity attaches to incumbent senior cabinet officials, then not only would any prosecution of such an official by South Africa be inconsistent with its (South Africa's) obligations under customary international law, but the ICC would also be prevented from instituting proceedings against such a person or requesting the surrender of that person (see P Gaeta 'Official Capacity and Immunities' in Cassese (eds), (n 9) 992). The only exception to this situation 


\section{South Africa and the ICC}

South Africa's commitment to the provisions of the Rome Statute and the ICC Act were recently tested in response to the Security Council's referral of Al-Bashir to the ICC. Initially there was much confusion on South Africa's position in relation to the AU's Sirte resolution which provided that AU member states would not cooperate with the arrest warrant. After much equivocation over South Africa's position and criticism from civil society organisations the South African Government confirmed that it was committed to the arrest of President Al-Bashir in accordance with its international and domestic legal obligations. The South African Government has reportedly taken the view that if Al-Bashir arrives in South Africa he will be liable to arrest. ${ }^{63}$ This view is in accordance with art 27 of the Rome Statute and s 4(1) of the ICC Act which scraps immunity for persons accused of ICC crimes (see discussion above under immunity), more particularly in respect of Al-Bashir since the Security Council's decision to confer jurisdiction on the ICC is also a decision to confer jurisdiction in accordance with the Rome Statute (including art 27 which strips immunity of all officials, whatever their status). Furthermore, the South African government reportedly stated that the arrest warrant has been endorsed by a South African magistrate in accordance with the ICC Act and was therefore active in South Africa which confirms South Africa's support for the arrest of Al-Bashir. ${ }^{64}$

Regarding the relationship between art 98 and art 27 of the Rome Statute, South Africa accordingly appears to have taken a robust position that notwithstanding the fact that Sudan is not a state party to the Rome Statute Al-Bashir does not have an entitlement to immunity under art 27 of the Statute. In terms of the Act the South African courts are given the same power to 'trump' the immunities ordinarily attaching to officials of governments in terms of art 27 of the Rome Statute. ${ }^{65}$ The clarification of South Africa's position with regard to Al-Bashir is a welcome one since South Africa has a vital role to play as an African leader in support of the ICC. Hopefully the ICC Act will serve as an example to other African states parties in their efforts to give domestic effect to their obligations under the Rome Statute. ${ }^{66}$

would be a waiver of the immunity by the third state (Gaeta, ibid 993-4, argues that art 98 should be interpreted to mean that a request for the waiver of immunity will only be required if the state (whose national enjoys immunity) is not a party to the Rome Statute).

${ }^{63} \mathrm{M}$ du Plessis, 'Recent cases and developments: South Africa and the International Criminal Court' (2009) 3 South African Journal of Criminal Justice 441, 445.

${ }^{64} \mathrm{M}$ du Plessis and C Gevers, 'Making amend(ment)s: South Africa and the International Criminal Court from 2009 to 2010’ (2009) 34 South African Yearbook of International Law 1, 24.

65 Ibid.

${ }^{66} \mathrm{M}$ du Plessis, 'South Africa's International Criminal Court Act countering genocide, war crimes and crimes against humanity' (2008) 172 Institute for Security Studies Paper 12. 


\title{
Implementing at national level the amendments to the Rome Statute of the International Criminal Court with respect to the crime of aggression: A South African perspective
}

\author{
Gerhard Kemp
}

\begin{abstract}
South African law (statutory as well as common law) does not provide for the crime of aggression. This author suggested elsewhere that aggression as a crime under customary international law might be directly applicable in South African courts, but other considerations - notably the (constitutionalised) legality principle - probably renders this too weak a legal basis for the prosecution of alleged aggressors in South African courts. The (South African) Implementation of the Rome Statute of the International Criminal Court Act 27 of 2002provides that genocide, crimes against bumanity and war crimes are crimes under South African law. Apart from the explicit criminalisation of the three core crimes, Section 2 of the South African ICC Act also provides that 'any competent court in the Republic hearing any matter arising from the application of [the] Act must also consider and, where appropriate, may apply - (a) conventional international law, and in particular the [Rome] Statute; (b) customary international law; and (c) comparable foreign law.' Although the substantive parts of the South African ICC Act do not provide for the crime of aggression, the Preamble does refer to 'the crime of aggression' as a crime 'in terms of international law'.

In this contribution the implications of the adoption at the ICC Review Conference at Kampala, Uganda of Resolution RC/Res 6 (on the Crime of Aggression, 11 June 2010), will be considered from a South African perspective. The significance and interpretative value of paragraphs 4 and 5 of Annex III to Resolution RC/Res 6 (Understandings regarding the amend-
\end{abstract}


ments to the Rome Statute of the ICC on the crime of aggression) will be considered, given South Africa's approach to the incorporation of crimes under international law. Related matters such as the constitutional confirmation that customary international law is law in the Republic will also be considered.

In conclusion, the desirability to prosecute aggression at domestic level will be considered, given the strong emphasis on (positive) complementarity in terms of the prosecution of the other crimes within the jurisdiction of the ICC, and given the particularly complex nature of the crime of aggression.

\section{Mise en œuvre des amendements au Statut de Rome en ce qui concerne le crime d'agression au niveau national: Un point de vue Sud-Africain}

\section{Résumé}

La législation sud-africaine (La loi ainsi que la common law) ne prévoit pas le crime d'agression. Cet auteur a suggéré par ailleurs que l'agression comme crime en vertu du droit international coutumier pourrait être directement applicable dans les tribunaux sud-africains, mais d'autres considérations - notamment le principe de légalité (constitutionnalisé) - en font sans doute une base juridique trop faible pour la poursuite des agresseurs présumés devant les tribunaux sudafricains. La Loi 27 de 2002 de mise en cuvre (Afrique du Sud) du Statut de Rome de la Cour pénale internationale prévoit que le génocide, les crimes contre l'bumanité et crimes de guerre sont des crimes en vertu de la loi sud-africaine. En dehors de la criminalisation explicite des trois crimes principaux, la Section 2 de la loi sud-africaine de la CPI prévoit également que

tout tribunal compétent de la République qui entend une affaire découlant de l'application de [la] loi doit également examiner et, le cas échéant, peut appliquer (a) le droit international conventionnel, et en particulier le Statut [de Rome];

(b) le droit international coutumier, et (c) la loi comparable étrangère.

Bien que les parties substantives de la loi sud-africaine de la CPI ne prévoient pas le crime d'agression, le préambule se réfere au 'crime d'agression' comme un crime 'en termes de droit international'.

Dans cette contribution, les implications de l'adoption à la Conférence de révision de la CPI à Kampala, en Ouganda de la Résolution RC / Res 6 (sur le crime d'agression, 11 Juin 2010), sera considérée à partir d'un point de vue sud-africain. L'importance et la valeur interprétative des paragraphes 4 et 5 de l'annexe III à la Résolution RC / Res 6 (Mémorandums d'accord concernant les amendements au Statut de Rome de la CPI sur le crime d'agression) sera considérée, 
compte tenu de l'approche de l'Afrique du sud à l'incorporation des crimes en vertu du droit international. Des questions connexes telles que la confirmation constitutionnelle que le droit international coutumier est le droit de la République seront aussi considérés.

En conclusion, l'opportunité de poursuivre l'agression au niveau national sera considérée, étant donné l'accent mis sur la complémentarité (positive) en termes de poursuite des autres crimes relevant de la compétence de la CPI, et étant donné la nature particulièrement complexe du crime d'agression.

\section{Introduction}

The Preamble to the Implementation of the Rome Statute of the International Criminal Court Act, $2002^{1}$ identifies the crime of aggression as one of the core international crimes, together with genocide, crimes against humanity and war crimes:

throughout the history of human-kind, millions of children, women and men have suffered as a result of atrocities which constitute the crimes of genocide, crimes against humanity, war crimes and the crime of aggression in terms of international law.

The Implementation Act does in fact not criminalise the crime of aggression under South African law, neither does any other South African statute nor, arguably, does the common law. The reason why the Implementation Act does not provide for the crime of aggression (apart from the reference in the preamble) is clear: At the time of promulgation, in 2002, the Rome Statute of the International Criminal Court also did not provide for a definition of aggression. A definition (and conditions for the exercise of ICC jurisdiction over the crime of aggression) was only adopted at the Kampala Review Conference of the International Criminal Court in 2010.

It is not surprising that the Republic of South Africa, a past aggressor in the Southern African region and labelled as such by the Security Council, ${ }^{2}$ does not at present provide for the crime of aggression under domestic criminal law. This state

\footnotetext{
${ }^{1}$ South Africa Implementation of the Rome Statute of the International Criminal Court Act, Act no 27 of 2002 (SA Implementation of the Rome Statute of the International Criminal Court Act (2002)).

2 See United Nations Security Council (UNSC) Res 387(1976), 31 March 1976, S/Res/387(1976); UNSC Res 577(1985), 6 December 1985, S/Res/577(1985) ('acts of aggression' by South African Defence Force against Angola); UNSC Res 527(1982), 15 December 1982, S/Res/527(1982) ('premeditated aggressive act' by South Africa against Lesotho); UNSC Res 568(1985), 21 June 1985, S/Res/568(1985) ('acts of aggression' by South Africa against Botswana). For an international law perspective on these resolutions, see Martti Koskenniemi, 'The place of law in collective security' (1996) 17 Michigan Journal of International Law 455, 458.
} 
of affairs is, however, not unique to South Africa. Only a number of states provide for some or other form of aggression (or some or other form of the crime against peace) in terms of domestic criminal law. This author has pointed out elsewhere (with reference to provisions of the South African Constitution) that the crime of aggression under customary international law could be regarded as a crime under South African law. However, certain legal and practical (not to mention political) considerations render this an uncertain and weak legal framework for purposes of prosecuting aggressors in South African criminal courts. ${ }^{3}$

The adoption of a definition of aggression, and the amendments agreed upon at the Kampala Review Conference of the Rome Statute of the International Criminal Court in June $2010^{4}$ (hereafter 'the Resolution on Aggression'), provides an opportunity for states to incorporate and indeed domesticate the 'supreme international crime'. The critical question is whether incorporation of the amendments to the Rome Statute concerning the crime of aggression is indeed advisable for states, including South Africa, which has incorporated the Rome Statute, ${ }^{5}$ thus transforming the core international crimes provided for in the Statute into crimes under South African law. ${ }^{6}$

To answer the above question, this contribution will first focus on some key provisions and characteristics of the Resolution on Aggression adopted at Kampala in 2010. Secondly, the desirability of providing for the crime of aggression under domestic law is considered, also with reference to comparative provisions under national criminal justice systems. The concluding part contains a recommendation of how South Africa should proceed in terms of the Resolution on Aggression adopted at Kampala.

\section{Key provisions and characteristics of the Resolution on Aggression}

\subsection{The substantive law}

It is clear that article 8bis of the Resolution on Aggression (to be included in the Rome Statute) constitutes a confirmation of the legacy of Nuremberg (that is the

\footnotetext{
${ }^{3}$ Gerhard Kemp, Individual criminal liability for the international crime of aggression (Intersentia 2010) 165.

${ }^{4}$ Resolution RC/Res 6 Adopted at the 13th plenary meeting of the Review Conference of the Rome Statute of the International Criminal Court, on 11 June 2010, by consensus.

${ }^{5}$ See SA Implementation of the Rome Statute of the International Criminal Court Act (2002).

${ }^{6}$ For a discussion see Max du Plessis, 'Bringing the International Criminal Court home - the Implementation of the Rome Statute of the International Criminal Court Act 2002' (2003) 16 South African Journal on Criminal Justice 1-16; Max du Plessis, 'South Africa's Implementation of the ICC Statute' (2007) 5 Journal of International Criminal Justice 460-479; Anton Katz, 'An Act of transformation - The incorporation of the Rome Statute of the ICC into national law in South Africa' (2003) 12(4) African Security Review 25-30.
} 
criminalisation of the unlawful use of force under international law, or, crimes against peace) as well as the criminalisation of state acts of aggression, short of 'total war' (that is essentially the acts of aggression provided for in the United Nations General Assembly Definition of Aggression of 1974). ${ }^{7}$ The crime of aggression under article 8 bis is also firmly linked to individual responsibility of persons in leadership or command positions (that is an individual who is in a position effectively to exercise control over or to direct the political or military action of a State'). ${ }^{8}$ This leadership crime par excellence is further qualified by the threshold requirement; thus limiting the crime of aggression to an act that by its character, gravity and scale, constitutes a manifest violation of the Charter of the United $\mathrm{Na}$ tions.' Reflecting the marriage between the Nuremberg/Tokyo notion of aggression ('crimes against peace') and the 1974 General Assembly Definition of Aggression, the following Elements of Aggression were adopted at Kampala:

Introduction

1. It is understood that any of the acts referred to in Article 8bis, paragraph 2, qualify as an act of aggression.

2. There is no requirement to prove that the perpetrator has made a legal evaluation as to whether the use of armed force was inconsistent with the Charter of the United Nations.

3. The term 'manifest' is an objective qualification.

4. There is no requirement to prove that the perpetrator has made a legal evaluation as to the 'manifest' nature of the violation of the Charter of the United Nations.

Elements

1. The perpetrator planned, prepared, initiated or executed an act of aggression.

2. The perpetrator was a person in a position effectively to exercise control over or to direct the political or military action of the State which committed the act of aggression.

\footnotetext{
${ }^{7}$ For a comprehensive discussion of the crime of aggression under art 8bis, see Kai Ambos, 'The crime of aggression after Kampala' (2010) 53 German Yearbook of International Law 463-509. For an account of the process at Kampala and the significance of the 'compromise text' adopted, see Claus Kress and Leonie von Holtzendorff, 'The Kampala Compromise on the Crime of Aggression' (2010) 8 Journal of International Criminal Justice 1179-1217. See also Claus Kress and Philippa Webb (2012) 1 Journal of International Criminal Justice, for various contributions on the crime of aggression after the Kampala Review Conference.

8 See art 8bis para 1. Article 25(3) of the Rome Statute (Rome Statute of the International Criminal Court, 2187 UNTS 90, 17 July 1998, entered into force 1 July 2002) was also amended in order to reflect this limitation on individual responsibility. Article 25(3bis) limits individual responsibility for the crime of aggression to those responsible leaders.
} 
3. The act of aggression - the use of armed force by a State against the sovereignty, territorial integrity or political independence of another State, or in any other manner inconsistent with the Charter of the United $\mathrm{Na}$ tions - was committed.

4. The perpetrator was aware of the factual circumstances that established that such a use of armed force was inconsistent with the Charter of the United Nations.

5. The act of aggression, by its character, gravity and scale, constituted a manifest violation of the Charter of the United Nations.

6. The perpetrator was aware of the factual circumstances that established such a manifest violation of the Charter of the United Nations.

Article 8 bis, to be inserted after article 8 of the Rome Statute, reads as follows:

1. For the purpose of this Statute, 'crime of aggression' means the planning, preparation, initiation or execution, by a person in a position effectively to exercise control over or to direct the political or military action of a State, of an act of aggression which, by its character, gravity and scale, constitutes a manifest violation of the Charter of the United Nations.

2. For the purpose of paragraph 1, 'act of aggression' means the use of armed force by a State against the sovereignty, territorial integrity or political independence of another State, or in any other manner inconsistent with the Charter of the United Nations. Any of the following acts, regardless of a declaration of war, shall, in accordance with United Nations General Assembly resolution 3314 (XXIX) of 14 December 1974, qualify as an act of aggression:

a) The invasion or attack by the armed forces of a State of the territory of another State, or any military occupation, however temporary, resulting from such invasion or attack, or any annexation by the use of force of the territory of another State or part thereof;

b) Bombardment by the armed forces of a State against the territory of another State or the use of any weapons by a State against the territory of another State;

c) The blockade of the ports or coasts of a State by the armed forces of another State;

d) An attack by the armed forces of a State on the land, sea or air forces, or marine and air fleets of another State;

e) The use of armed forces of one State which are within the territory of another State with the agreement of the receiving State, in contravention of the conditions provided for in the agreement or any exten- 
sion of their presence in such territory beyond the termination of the agreement;

f) The action of a State in allowing its territory, which it has placed at the disposal of another State, to be used by that other State for perpetrating an act of aggression against a third State;

g) The sending by or on behalf of a State of armed bands, groups, irregulars or mercenaries, which carry out acts of armed force against another State of such gravity as to amount to the acts listed above, or its substantial involvement therein.

\subsection{Conditions for the exercise of International Criminal Court jurisdiction over the crime of aggression}

The definition of the crime of aggression was always a difficult stumbling block on the road to effective International Criminal Court (ICC) jurisdiction over this crime, but perhaps the most difficult part of the process was the conditions for the exercise of ICC jurisdiction, and notably the role of the Security Council. ${ }^{9}$ At the heart of this debate are the different perspectives on criminal justice versus political responses to acts of aggression. Even before the adoption of the Resolution on Aggression at the Kampala Review Conference in June 2010, it was warned that ' $\mathrm{r}$ ] omantic or idealistic views of a totally independent role for the ICC Prosecutor (i.e. without any role for the Security Council, or other international bodies) are not helpful.' On the other hand, to grant what would amount to a veto to the Security Council over the Prosecutor in matters concerning the prosecution of the crime of aggression, represents the other extreme. ${ }^{10}$

The package of provisions adopted at Kampala on the exercise of ICC jurisdiction over the crime of aggression reflects a finely balanced approach; confirming the independence of the Court while acknowledging the political role of the Security Council in matters of international peace and security. Article $15 \mathrm{bis}$ provides for State referrals and proprio motu investigations by the Prosecutor. Article 15ter provides for Security Council referrals. The reluctance of states to subject the use of force to criminal jurisdiction of an international court is further reflected in the agreement that the ICC may exercise its jurisdiction over the crime of aggression at the earliest after 1 January 2017. This is further dependent on the decision by a majority of the States parties (pursuant to Article 15bis paragraph 3 and Article 15ter paragraph 3 invoking the required Rome Statute amendment majorities) and one year has passed since such amendment has been accepted by the first 30 State

\footnotetext{
${ }^{9}$ For more on the pre-Kampala debates and processes, see Muhammad Shukri, 'Will aggressors ever be tried before the ICC?' in Mauro Politi and Giuseppe Nesi (eds), The International Criminal Court and the Crime of Aggression (Ashgate 2004) 37-42.

${ }^{10}$ See comments on the pre-Kampala proposals in Kemp (n 4) 236.
} 
parties (Article 15bis paragraph 2; Article 15ter paragraph 2). The Security Council's role in matters of international peace and security is underscored by the Understandings that were adopted at Kampala (contained in Annex III to the Resolution on Aggression). The result is that a Security Council referral is binding for non-party states as well. This basis for ICC jurisdiction over a situation referred to it by the Security Council is, of course, not unique to the crime of aggression. ${ }^{11}$

\section{The complementarity imperative: National jurisdiction over the crime of aggression (or rather not?)}

Although the crime of aggression has been characterized by the Nuremberg Tribunal as the 'supreme international crime', ${ }^{12}$ only a relatively small number of countries have criminalised the crime (aggression strictu sensu) under their domestic law. ${ }^{13} \mathrm{~A}$ number of reasons can be advanced for this state of affairs. The most important reasons seem to be the 'political' nature of the crime, and the decadeslong debate about a suitable definition for the 'expanded' notion of aggression that is aggression as a crime against peace as prosecuted at Nuremberg and later Tokyo, plus the later suggestions to include 'other acts of aggression' within the international criminal notion. ${ }^{14}$

This author suggested that the adoption of a definition of aggression at international level could provide an impetus for states to also provide for the crime at national level. However, it was also warned that certain problems - mainly stemming from the unique features of the notion of aggression - will remain and will make it difficult for the crime to be implemented at national level. This is particularly the case where states would want to exercise jurisdiction over state acts of aggression initiated and directed by non-nationals. ${ }^{15}$

\footnotetext{
11 See Rome Statute, art 13(b). For more background and analyses, see Roy S Lee, The International Criminal Court - The Making of the Rome Statute (Kluwer Law International 1999) 146-149.

12 International Military Tribunal (Nuremberg trial) Judgment (1946), IMT 171, at 186:

War is essentially an evil thing. Its consequences are not confined to the belligerent States alone, but affect the whole world. To initiate a war of aggression, therefore, is not only an international crime; it is the supreme international crime differing only from other war crimes in that it contains within itself the accumulated evil of the whole.

${ }^{13}$ For an overview see Sergey Sayapin, 'The compatibility of the Rome Statute's draft definition of the crime of aggression with national criminal justice systems' (2010) 81 Revue Internationale de DroitPénal 165-187. For another comparative perspective, see A Reisinger Coracini, 'Evaluating domestic legislation on the customary crime of aggression under the Rome Statute's complementarity regime' in Carsten Stahn and Göran Sluiter (eds), The Emerging Practice of the International Criminal Court (Brill 2009) 735.

${ }^{14}$ Notably the list of state acts of aggression provided for in the UN General Assembly Definition of Aggression, GA Res 3314 (xxix), 29 UN GAOR Supp No 31, 142 UN Doc A/9631 (1974).

15 See Kemp (n 4) 254-255. For further arguments in support of this cautious approach, see Beth Van Schaack, 'Par in Parem Imperium Non Habet - Complementarity and the Crime of Aggression' (2012) 10 Journal of International Criminal Justice 133-164.
} 
In the absence of domestic law explicitly criminalising the international crime of aggression, some suggest that the direct application of international law in domestic courts ${ }^{16}$ can provide a legal basis for the prosecution of individuals responsible for crimes under international law - notably crimes that have attained customary status. The argument goes that since the crime of aggression (as applied at Nuremberg and later Tokyo) has acquired customary status, individuals can be prosecuted for this crime in domestic courts. In $\mathrm{R} v$ Jones and others ${ }^{17}$ the House of Lords in England considered an appeal that, in essence, concerned the following assertions:

Aggression is recognised as a crime under customary international law; customary international law is (without the need for any statute or judicial decision) part of the domestic law of England and Wales; and efforts to prevent the crime of aggression must be seen as legal justifications for what would otherwise be criminal acts. ${ }^{18}$

Whether a crime under customary international law can be applied as such in a domestic court, seems to be problematic. Lord Bingham of Cornhill stated:

It was suggested, on behalf of the Crown, that the crime of aggression lacked the certainty of definition required of any criminal offence, particularly a crime of this gravity. This submission was based on the requirement in article 5(2) of the Rome Statute that the crime of aggression be the subject of definition before the international court [ICC] exercised jurisdiction to try persons accused of that offence. This was an argument which found some favour with the Court of Appeal [...] I would not for my part accept it. It is true that some states parties to the Rome statute have sought an extended and more specific definition of aggression. It is also true that there has been protracted discussion of whether a finding of aggression against a state by the Security Council should be a necessary pre-condition of the court's [ICC] exercise of jurisdiction to try a national of that state accused of committing the crime. I do not, however, think that either of these points undermines the appellants' essential proposition that the core elements of the crime of aggression have been understood, at least since 1945, with sufficient clarity to permit the lawful trial (and, on conviction, punishment) of those accused of this most serious crime. It is unhistorical to suppose that the elements of the crime were clear in 1945 but have since become in any way obscure. ${ }^{19}$

\footnotetext{
${ }^{16}$ For more on this debate see Ward Ferdinandusse, Direct application of International Criminal Law in National Courts (TMC Asser Press 2006).

${ }_{17} \mathrm{R} v$ Jones and others (Conjoined Appeals) 29 March 2006, 45 International Legal Materials 992 (2006).

${ }^{18}$ See discussion by Kemp (n 4) 157.

${ }^{19}$ Lord Bingham of Cornhill in Jones ( $\left.\mathrm{n} 18\right)$ para 19.
} 
While the House of Lords accepted that the crime of aggression (as prosecuted at Nuremberg and later Tokyo) has attained customary status, the assimilation of crimes under international law into domestic English law is not automatic. Parliament should be the creator of new crimes and customary international law may very well be the legal basis or justification for Parliament to legislate on crimes under international law. Indeed, one can take Lord Bingham's analysis further and argue that the incorporation of the amendments to the Rome Statute concerning the crime of aggression (the Resolution on Aggression adopted at Kampala) would remove any doubt as to the elements of the crime of aggression - of which the core elements have indeed since at least 1945 been sufficiently clear to have customary status.

The above illustrated common law proposition regarding the application of the crime of aggression in domestic courts can also be analysed with reference to a provision in South Africa's progressive constitution. ${ }^{20}$

Section 232 of the Constitution of South Africa provides as follows: 'Customary international law is law in the Republic unless it is inconsistent with the Constitution or an Act of Parliament.' On the face of it this provision could be regarded as confirmation of the position that the customary international crime of aggression is a crime under South African law. A good indication of the Constitutional Court's view of section 232 as a basis to apply customary international criminal law directly (that is without legislation incorporating or transforming such law into domestic South African criminal law) is former Chief Justice Chaskalson's obiter statement in $S v$ Basson $^{21}$ :

If the conduct with which the accused was charged did not constitute an offence under South African law at the time it was committed [...] the State cannot contend that it has become an offence because of the provisions of the Constitution [section 232]. ${ }^{22}$

The above statement concerns the retroactive application of customary international criminal law in South Africa, which is clearly not allowed. The question is whether customary international criminal law can be directly applied in South African courts with respect to events (possible crimes) committed after the entry into force of the Constitution of 1996. The principle in South African constitutional jurisprudence is that the Constitution does not have retroactive operation or im-

\footnotetext{
${ }^{20}$ For more on the possible role of sec 232 of the Constitution of 1996 in the application of international criminal law before South African courts, see Gerhard Erasmus and Gerhard Kemp, 'The application of international criminal law before domestic courts in the light of recent developments in international and constitutional law' (2002) 27 South African Yearbook of International Law 64-81.

21 S v Basson 2005 (1) SA 171 (CC) (South Africa). On the problematic nature of the prosecution's case against Basson, and in particular the difficulty with the argument about the prosecution for crimes under customary international criminal law, see remarks by Wim Trengove, A Tribute of Power to Reason: The relevance of the International Criminal Court to South Africa (Konrad Adenauer Stiftung 2006) 38-42.

22 Basson (n 22) separate opinion of Chaskalson CJ para 97.
} 
pact. ${ }^{23}$ It is submitted that other constitutional principles - notably the (constitutionalised) legality principle - may preclude the direct application of customary international criminal law in South African criminal courts, even with reference to possible crimes under customary international criminal law committed after the entry into force of the Constitution. ${ }^{24}$

Prominent publicists pointed out that the 'waging of aggressive war' is a crime under customary international law. Werle, for instance, put the position as follows:

[Aggressive] war is criminal under customary international law. The scope of the offence must be determined on the basis of the only precedents to date, the Nuremberg and Tokyo judgments [...] However, there is no evidence that acts of aggression not reaching the level of intensity of aggressive war are criminal under customary international law. ${ }^{25}$

Assuming that the elements of the narrower concept of 'waging of aggressive war' are clear so as to satisfy the legality principle, the broader notion of aggression (that is war plus other 'acts of aggression') that developed after the Second World War (as reflected in the General Assembly Definition of Aggression of 1974) was, until the Kampala Review Conference of 2010, so contentious that the drafters of the Rome Statute of the International Criminal Court of 1998 could not agree on the inclusion of a definition in the text of 1998. To rely on the customary international crime of aggression for prosecution in a domestic court would thus at best be limited to the Nuremberg-precedent. Even then the test under South African criminal law (applying the constitutionalised legality principle) would be whether the elements of the crime in question were clear and precise 'so that an individual may easily behave in a manner that avoids committing crimes.' 26 It is submitted that the Nuremberg-precedent (followed by the Nuremberg Principles) ${ }^{27}$ provide a clear enough picture of the crime of aggression in the form of 'waging a war of aggression'. However, it is also clear that the very contentious nature of the debate about a definition of the 'crime of aggression' under international criminal law precludes direct application of the latter notion via section 232 of the Constitution of 1996. This brings us to the opportunity presented by the adoption of a definition of aggression at the Kampala Review Conference of 2010 and the question whether South Africa should, in light of the above, ratify and also incorporate the Kampala definition of aggression into domestic South African law.

\footnotetext{
${ }^{23}$ See Du Plessis and others v De Klerk and another 1996 (3) SA 850 (CC) (South Africa).

${ }^{24}$ See discussion of sec 35 of the Constitution, 1996, in Gerhard Kemp, Supreme crimes and outrageous acts: criminalisation and the legality principle - a South African and international perspective (Inaugural lecture, Stellenbosch University Faculty of Law, Stellenbosch, September 2010).

${ }^{25}$ Gerhard Werle, Principles of International Criminal Law (2nd edn, TMC Asser Press 2009) 484.

26 See opinion of Nkabinde J in Masiya v Director of Public Prosecutions, Pretoria and another (Centre for Applied Legal Studies and another, Amici Curiae) 2007 (5) SA 30 (CC) (South Africa) para 52.

${ }_{27}$ UN General Assembly, Nuremberg Principles, 29 July 1950, UNGAOR, 5th Session, Supp No 12, UN Doc A 1316 (1950).
} 


\section{Implementing the crime of aggression under domestic law: A comparative perspective}

South Africa is a state party to the Rome Statute of the International Criminal Court and has incorporated the statute into domestic law, thus providing for (a) an effective framework to co-operate with the International Criminal Court (ICC) and (b) substantive jurisdiction over the crimes of genocide, crimes against humanity and war crimes - the crimes over which the ICC also has jurisdiction.

Should South Africa follow the same approach with regards to the controversial and complex crime of aggression - which falls within the jurisdiction of the ICC and which is the subject of an important resolution that was adopted at the First Review Conference of the Rome Statute of the ICC at Kampala, Uganda in June 2010? The Review Conference (at which South Africa as a state party participated) called upon all state parties to ratify or accept the amendments to the Rome Statute concerning the definition of the crime of aggression, as well as the exercise of ICC jurisdiction over the crime.

Since the focus here is on domestic jurisdiction over the crime of aggression, the implications of Article 15bis (exercise of ICC jurisdiction over the crime of aggression after a state referral, or proprio motu investigation by the ICC Prosecutor) and Article 15ter (exercise of ICC jurisdiction after UN Security Council referral) will only be considered in the context of the crime of aggression under domestic law.

Annex III of Resolution RC/Res 6 of 11 June 2010 contain certain Understandings regarding the amendments to the Rome Statute that can have important interpretative value; and these understandings also reflect some of the compromises and diplomatic dynamics preceding Kampala as well as at the conference itself. Paragraphs 4 and 5 of Annex III read as follows:

4. It is understood that the amendments that address the definition of the act of aggression and the crime of aggression do so for the purpose of this Statute [the Rome Statute] only. The amendments shall, in accordance with article 10 of the Rome Statute, not be interpreted as limiting or prejudicing in any way existing or developing rules of international law for purposes other than this Statute.

5. It is understood that the amendments shall not be interpreted as creating the right or obligation to exercise domestic jurisdiction with respect to an act of aggression committed by another State.

The meaning and potential impact of the above Understandings must be analysed with reference to the current state of affairs in terms of national criminal jurisdiction over the crime of aggression. The legal status of the Understandings seems 
uncertain. ${ }^{28}$ The most realistic view seems to be that the Understandings will ultimately serve as travaux préparatoires, after the 2017 Review Conference which will presumably adopt the aggression amendments (the Kampala Resolution). ${ }^{29}$ Regardless of the legal status, Understandings 4 and 5 (and especially Understanding 5) are indications of a preference against incorporation of the definition of aggression into domestic criminal law. ${ }^{30}$

It was pointed out above that the crime of aggression is not a crime under South African law. The usefulness of section 232 of the Constitution of 1996 to prosecute the customary international crime of aggression ('waging of a war of aggression') also seems to be doubtful. But what is the comparative position in other jurisdictions?

A useful starting point is the different models employed by Sergey Sayapin to analyse the crime of aggression (in one form or another) in national legal systems. The author divided the national provisions into the following models: The $\mathrm{Nu}$ remberg and Tokyo' model; the 'territorial integrity' or 'political independence' model; the 'war' (or 'objective') model; the 'treason' model. ${ }^{31}$

The first model ('Nuremberg and Tokyo') provides for the criminalisation of the planning, preparation and waging of a 'war of aggression'. Some national systems that fall within this category only provide for the planning/preparation of an aggressive war, but it is suggested that this should logically cover the actual waging of the war as well. Section 80 of the German Criminal Code (Strafgesetzbuch) provides for the crime of 'preparation of aggressive war.'32 A unique 'domesticated' version of the crime of 'waging a war of aggression' can be found in the Statute of the Iraqi Special Tribunal, which was created by the American-led Coalition Provisional Authority after the regime of Saddam Hussein was ousted by military force in 2003. In terms of the Statute, the Tribunal has jurisdiction over Iraqi nationals or residents for crimes committed since 17 July 1968 up until 1 May 2003 in the territory of Iraq or elsewhere, namely the crime of genocide, crimes against humanity, war crimes, and violations of certain Iraqi laws. The latter category of crimes includes: The abuse of position and the pursuit of policies that may lead to the threat of war or the use of the armed forces of Iraq against an Arab country, in accordance with Article 1 of Law Number 7 of 1958, as amended.

\footnotetext{
${ }^{28}$ Kevin Jon Heller, 'The uncertain legal status of the Aggression Understandings' (2012) 10 Journal of International Criminal Justice 229-248.

${ }^{29}$ Heller (n 29) 248.

${ }^{30}$ Van Schaack (n 16) 155.

${ }^{31}$ Sayapin (n 14) 169-185.

${ }^{32}$ For a discussion see Helmut Satzger, 'German Criminal law and the Rome Statute - A critical analysis of the New German Code of Crimes against International Law' (2002) 2 International Criminal law Review 261-282; Heinrich Wilhelm Laufhütte in Burkhard Jähnke, Heinrich Wilhelm Laufhütte and Wlater Odersky, Strafgesetz̧buch - Leipziger Kommentar Band 4 (11th edn, De Gruyter Recht 2005) 1-30.
} 
This version of "waging a war of aggression" is thus of limited scope, and not a general incorporation of the Nuremberg-precedent. It would thus be possible for the Iraqi Tribunal to try individuals for the invasion of Kuwait by Iraq in the early 1990's, but not acts of aggression beyond the region mentioned in the relevant law of 1958.33

While the German and Iraqi examples illustrate only tentative or limited jurisdictional incorporation of the Nuremberg-precedent, the criminal code of Georgia criminalises aggression in close resemblance of Nuremberg:

Planning of or preparing for the war of aggression shall be punishable by prison sentences ranging from seven to fifteen years in length. Unleashing or waging of the war of aggression shall be punishable by imprisonment extending from ten to twenty years in length or by life imprisonment. ${ }^{34}$

States that incorporate the Nuremberg-precedent in full or in some form or another, include Poland, ${ }^{35}$ Serbia, ${ }^{36}$ Estonia $^{37}$ and Montenegro ${ }^{38}$.

Sayapin has identified a second approach towards the criminalisation of aggression at domestic level. He regards this approach as being inspired by Article 2(4) of the UN Charter and labels it the 'territorial integrity or political independence model'. ${ }^{39}$ Sayapin describes the approach as follows:

The norms of national criminal laws which conform to this model contain references to "aggression" and are typically phrased in terms of protecting "independence" and "integrity" of the State concerned from "subjugation", "war", "dependency", "foreign rule" and other similar consequences or threats. Here, the scope of the criminalised individual conduct is considerably broader than that which is required by the "Nuremberg and Tokyo model": the perpetrator need not bring about a "war of aggression", in order for the criminal liability and punishment to occur, for it suffices if an individual contributes to the commission of a hostile act (such as the "use of force") against the protected interests of a State, or even simply attempts or threatens to do so. ${ }^{40}$

Given the broader scope of this second approach to the national criminalisation of aggression, Sayapin noted that this approach 'is quite compatible' with the draft article 8 bis (which was indeed eventually adopted at the Kampala Review Confer-

\footnotetext{
33 See further comments by Claus Kress, 'The Iraqi Special Tribunal and the crime of aggression' (2004) 2 Journal of International Criminal Justice 348.

34 See art 404 of the Criminal Code of Georgia (translation in Sayapin (n 14) 172).

35 Art 117 Criminal Code of Poland.

36 Art 386 Criminal Code of Serbia.

37 Para 91 Criminal Code of Estonia.

38 Art 442 Criminal Code of Montenegro.

${ }^{39}$ Sayapin (n 14) 175.

40 Sayapin (n 14) 175-176.
} 
ence). This approach goes further than the Nuremberg-approach, which essentially criminalises aggressive war. Other acts of aggression (in particular the use of armed force) are criminalised, notably the use of armed force which threatens a state's political independence or territorial integrity. From the national examples referred to by Sayapin, the one aspect of this approach that differentiates it from article $8 b i s$, is the fact that almost all the national examples include elements of the crime of treason, thus combining the international and the purely national. For instance, the Criminal Code of Argentina describes the perpetrator of the crime (acts directed at a total or partial submission of the nation to a foreign domination or threatening its independence or integrity as well as inducing or permitting a foreign power to wage a war against the republic) as any person 'who owes obedience to the Nation by virtue of his or her employment in a public function'. ${ }^{41}$ Apart from this material limitation, Sayapin nevertheless concludes that this 'territorial integrity or political independence model' of national criminalisation of the crime of aggression, is substantively compatible with article 8 bis. ${ }^{42}$ It must be noted, however, that this approach should be refined in order to bring a clearer distinction between the crimes of aggression (under article 8bis) and the crime of treason, which concerns other protected interests and has its own history. ${ }^{43}$

The third approach identified by Sayapin is the so-called 'war model or objective model'. The focus here is on the criminalisation of the fact of 'war', 'declarations of war', 'hostilities' and similar objectively measurable phenomena. While this approach is also based on the prohibition of the use of force in terms of the UN Charter, the focus is on 'objective manifestations rather than subjective purposes of the use of force.' 44 Where this approach to the crime of aggression is criminalised under domestic law, the mental elements consists in the perpetrator's 'direct intent to commence an armed conflict' 45 against another state. Sayapin refers to the example of Romania, which criminalises 'war' and the 'commission of hostile acts' against member states of the European Union, the Council of Europe, and the North Atlantic Treaty Organisation. The clear protected legal interest here is the prohibition of hostile acts or war as such against a certain group of states without reference to the motivation for the war or hostile military act. ${ }^{46}$ Sayapin points out (correctly) that the question about the precise starting moment of 'war' or 'armed conflict' is still an unresolved issue in international law. ${ }^{47}$ This problem might

41 See art 214 and art 215 of the Criminal Code of Argentina, as discussed in Sayapin (note 14) 176.

42 Sayapin (n 14) 178.

43 For a South African (and historical Roman Dutch perspective) see CR Snyman, Strafreg (5th edn, LexisNexis 2006) 316-324.

44 Sayapin (n 14) 179.

45 Ibid.

46 See art 279 of the Criminal Code of Romania as discussed by Sayapin (n 14) 181.

47 In the old case Driefontein Consolidated Gold Mines v Janson [1900] 2 QB 339, at 343, 'war' was defined as:

When differences between States reach a point at which both parties resort to force, or one of them does acts of violence, which the other chooses to look upon as a breach of the peace, the 
therefore affect the usefulness of the third approach to the crime of aggression for purposes of compatibility with article 8bis accepted at the Kampala Review Conference. However, Sayapin also points out that the second part of article 8 bis contain examples of objective uses of armed force (paragraph 2, (a) to (g)). ${ }^{48} \mathrm{National}$ definitions of aggression that refers to 'invasion or attack by the armed forces', 'bombardment by the armed forces' (and other objective manifestations of the use of armed force against another state) could therefore serve as a good starting point and can even be regarded as compatible with at least the second part of article 8bis.

The final approach referred to by Sayapin is the 'treason model'. He notes that 'this model is concerned with "internal" hostile relations between a State and its nationals, which ultimately lead to the involvement of that State in an international armed conflict'. Conduct that 'aggravate the situation of that State, if it already is at war with another State' would also fall within this approach. ${ }^{49}$ Given the statecentric interest at stake, many if not most states provide for the crime of treason in some form or another in their domestic criminal law. In South Africa, treason in times of war is not a separate crime, but it is generally regarded as a serious manifestation of the crime of treason. A number of South African cases confirm the link between assistance to the enemy in a time of war and the crime of treason. ${ }^{50}$ Given the particular state-centric interests underlying the criminalisation of treason, this author is of the view that the 'treason-model' identified by Sayapin is not very helpful in terms of the question of whether domestic criminal law is compatible with the crime of aggression as defined in article 8 bis.

\section{Concluding remarks}

The crime of aggression as provided for in art 8bis (Resolution on Aggression adopted at the Kampala Review Conference) is a remarkable achievement, at least in the sense that it concludes an historic debate in international criminal law, while at the same time opens a new one; a debate that states parties to the Rome Statute now have the opportunity to take further. The focus of the Review Conference was of course to finish the process prompted by article 5(2) of the Rome Statute, namely the drafting of a definition of aggression, and conditions for the exercise of

relation of war is set up, in which the combatants may use regulated violence against each other, until one of the two has been brought to accept such terms as his enemy is willing to grant.

The author Yoram Dinstein proposed the following definition of war:

War is a hostile interaction between two or more States, either in a technical or in a material sense. War in the technical sense is a formal status produced by a declaration of war. War in the material sense is generated by actual use of armed force, which must be comprehensive on the part of at least one party to the conflict.

See Yoram Dinstein, War Aggression and Self-Defence (4th edn, Cambridge University Press 2005) 15.

48 Sayapin (n 14) 181-182.

${ }^{49}$ Sayapin (n 14) 182.

${ }^{50}$ See cases referred to by Snyman (n 44) 319-320. 
ICC jurisdiction over the crime. The adoption of a definition of aggression for ICC purposes will also provide an opportunity for states to provide for the crime of aggression under their domestic law.

It is submitted that South Africa now has the opportunity to debate the merits of incorporating the definition of aggression under article 8bis. Since this amendment to the Rome Statute can only become effective after 2017 (as pointed out above), South Africa can make use of the next few years to debate and explore the issue of providing for the crime of aggression under domestic criminal law. It was pointed out above that where states do provide for the crime under domestic law, they do so in various ways. Section 232 of the Constitution, 1996 provides for the theoretical possibility to prosecute individuals for the customary international crime of aggression (essentially 'wars of aggression'). However, even if this is possible in theory, the practical and criminal justice obstacles will make it extremely unlikely that an individual will in fact be prosecuted on the basis of section 232 of the Constitution. If South Africa is therefore serious about the sentiment expressed in the Preamble to the Implementation of the Rome Statute of the International Criminal Court Act, 2002, namely that aggression is indeed one of the core crimes under international criminal law (together with genocide, crimes against humanity and war crimes) it must take the debate about possible domestic implementation of article 8bis very seriously.

Incorporation of article 8bis will, in light of the Understandings referred to above, not be mandatory in the context of the complementarity regime. Given the 'political' nature of the crime of aggression as a leadership crime, the assumption is that many states will opt not to incorporate the crime of aggression with respect to non-nationals under domestic law. Those states that already provide for some or other form of the crime of aggression under domestic law will also not have to conform to the scope of article 8bis. Indeed, my assumption is that many states parties will regard aggression as essentially a leadership crime, best prosecuted at international level, before the ICC.

Difficult issues like the debate about legitimate (albeit illegal or unilateral) humanitarian intervention ${ }^{51}$ and South Africa's own role as a regional power will probably inform the debate as well. ${ }^{52}$ These difficult and complex issues notwith-

\footnotetext{
51 Some scholars fear that ICC jurisdiction over the crime of aggression could become a blunt instrument that would make it possible to prosecute cases of 'legitimate' humanitarian intervention. Indeed, there is a school of thought that the use of armed force in the context of wars of national liberation (i.e. third party use of armed force) and humanitarian intervention should generally be regarded as exceptions to the criminal notion of aggression. Textually, art 8bis of the Resolution of Aggression adopted at Kampala does not deal with these issues. That means that the use of force (including unilateral humanitarian intervention) will probably be regarded as at least prima facie aggression. For more on this debate see Kemp (n 4) 64-68; Elise Leclerc-Gagne and Michael Byers, 'A question of intent: The crime of aggression and unilateral humanitarian intervention' (2009) 41 Case Western Reserve Journal of International Law 379-390.

52 For critical observations regarding African perspectives on international criminal justice, and the development of international criminal law on the continent, see Dire Tladi, 'The African Union and
} 
standing, it is submitted that article 8bis, adopted at the Kampala Review Conference, presents a realistic and balanced compromise text, suitable for further discussion at national level for possible domestic implementation. The comparative national approaches referred to above could be helpful. Ultimately, however, South Africa will have to do what is best suitable in terms of its obligations under international law, the country's constitutional framework, and the supposed commitment to international criminal justice. The realist prognosis is that South Africa will probably ratify, but not incorporate, the Resolution on Aggression into South African domestic law.

the International Criminal Court: the battle for the soul of international law' (2009) 34 South African Yearbook of International Law 57-69. It must be noted that political elites in Africa seem to be ever more critical of not only the ICC, but also interventions by especially Western powers on the continent. These views might impact on the eventual incorporation of the crime of aggression in African states. In fact, it might strengthen the argument for the criminalization of acts of aggression under domestic law - especially if African states would regard unilateral Western 'humanitarian' intervention as unlawful interference; indeed as nothing less than the crime of aggression. 


\title{
Rwanda and the ICC: a need for the ratification of the Rome Statute
}

\author{
Christian Nsabimana Garuka*
}

'It is one step at ago and that is one good step. We hope ICC will continue to fulfill other steps to apprehend these wanted people. It was long overdue.'

\begin{abstract}
Rwanda is among the few African countries to have prosecuted cases related to genocide, war crimes and crimes against humanity and moreover has the experience of an ad-hoc tribunal (ICTR). Thus Rwanda has an experience of prosecuting the mentioned international crimes at home and also has some its nationals prosecuted by an international criminal tribunal.

Despite the experience on trying individuals for international crimes and moreover the commitment made by the Government of Rwanda in the fight against impunity, Rwanda has not ratified the Rome Statute and has consistently made public its reluctance if not refusal to do so. However, the Government of Rwanda welcomed the arrest and transfer of a Rwandan national to the ICC, accused for war crimes in the Democratic Republic of Congo.

The Paper explores all eventual arguments which are either against or in the interest of $\mathrm{R}$ wanda with regard to the ratification of the Rome Statute. The main arguments are political considerations, legal considerations and legal implications.
\end{abstract}

\footnotetext{
* The author is grateful to Dr. Jamil Mujuzi's comments on the previous draft. Errors remain mine.

1 Tharcisse Karugama, Minister of Justice of the Republic of Rwanda, reacting to the transfer of Callixte Mbarushimana from France to the ICC. Information reported by Edmund Kagire, 'Gov't welcomes Mbarushimana's arrest' Newtimes (11 October 2010) <http://mail.newtimes.co.rw/news/index.php?i=14411\&a=> accessed 28 May 2011.
} 
The chapter dealing with political considerations explores what the ratification which might either dictate Rwanda to ratify or not the Rome Statute. Indeed, the paper dismisses the argument that the ICC only prosecutes African. The paper submits that this issue was only raised subsequently to the issue of warrant of arrest against Al Bashir, the president of Sudan. This has not be the case when the ICC had to deal with rebel leaders as well as political opponents in various African states.

The chapter dealing with legal considerations argues that $\mathrm{R} w a n d a$ 's ratification of the Rome Statute will strengthen its compliance to several instruments dealing with international crimes to which Rwanda is a party. The chapter dealing with legal implications explores the consequences of the ratification of the Rome Statute such as the domestication of the Rome Statute, the issue of complementarity, extradition. Despite the fact there is a new trend in Africa of boycotting the ICC by the African Union, the paper concludes in arguing that it's for the interest of Rwanda to ratify the Rome Statute as far as commitment to the fight against impunity is concerned and moreover that the 1194 genocide of a result of impunity.

\section{Le Rwanda et la CPI: une nécessité pour la ratifica- tion du Statut de Rome}

\section{Résumé}

Le Rwanda fait partie des quelques pays africains à avoir engagé des poursuites liées au génocide, à des crimes de guerre et des crimes contre l'bumanité et de plus il a l'expérience d'un tribunal adhoc (TCIR). Ainsi le Rwanda a une expérience des poursuites judiciaires pour les crimes internationaux mentionnés engagés sur son territoire et a également fait poursuivre certains de ses ressortissants par un tribunal pénal international.

En dépit de cette expérience des jugements d'individus pour des crimes internationaux et l'engagement du gouvernement rwandais dans le combat contre l'impunité, le Rwanda n'a pas ratifié le statut de Rome et a constamment manifesté ses hésitations sinon son refus à le faire. Cependant, le gouvernement du Rwanda a bien accueilli l'arrestation et le transfert d'un ressortissant rwandais devant le TPI, accusé de crimes de guerre dans la République démocratique du Congo.

L'article explore tous les arguments éventuels qui sont contre ou dans l'intérêt $d u$ Rwanda concernant la ratification du statut de Rome. Les principaux points développés sont des considérations politiques et juridiques et les implications légales.

Le chapitre traitant des considérations politiques explore ce qui dans la ratification pourrait inciter le Rwanda à ratifier ou pas le statut de Rome. En effet, l'article écarte l'argument que le CPI ne poursuit que des africains. L'article affirme que cette question n'a été soulevée que plus tard lorsqu'un mandat d'arrêt a été lancé contre Al Bashir, président du Soudan. Cela n'a pas 
été le cas quand le TPI a dû s'occuper des chefs rebelles ainsi que des adversaires politiques dans divers États africains.

Le chapitre traitant des considérations juridiques défend l'idée que la ratification par le Rwanda du statut de Rome renforcera sa conformité à plusieurs instruments affairant aux crimes internationaux dans lesquels le Rwanda est partie. Le chapitre traitant des implications légales explore les conséquences de la ratification du statut de Rome telle que la domestication du statut de Rome, la question de la complémentarité et l'extradition. En dépit du fait il y a une nouvelle tendance en Afrique au boycott du TPI par l'union africaine, l'article conclut en arguant du fait qu'il est dans l'intérêt du Rwanda de ratifier le statut de Rome si l'on considère son engagement à combattre l'impunité et que le génocide des 1194 est le résultat de l'impunité.

\section{Introduction}

In 1994, Rwanda experienced one of the most serious violations of international humanitarian law namely the genocide, war crimes and crimes against humanity. Since then, the Rwandan government has taken legal response in the prosecution of these violations and for future violations as well in enacting a law on the above mentioned crimes. Despite the fact that Rwanda has adopted these legislative measures, yet it has not ratified the Rome Statute considered as a relevant and landmark document in fighting impunity.

The establishment of the ICC through the Rome Statute has been supported by the African Continent in a way that the continent has many member parties to it compared to other continents. ${ }^{2}$ However, the indictment of Omar Al-Bashir, the President of Sudan, and the confirmation of charges against three Kenyan political leaders and a journalist accused for the post election violence in Kenya in 2007, the African Union is attempting to withdraw its cooperation with the ICC arguing that it is only targeting African States. ${ }^{3}$ Nevertheless, it is also argued that Africa is still divided on ICC's cooperation despite the AU resolution on ICC with some African States continuing to support the ICC. ${ }^{4}$ Despite the fact that Rwanda is among

\footnotetext{
2 As of 16 November 2011, 119 countries are States Parties to the Rome Statute of the International Criminal Court. Out of them 33 are African States, 17 are Asia-Pacific States, 18 are from Eastern Europe, 26 are from Latin American and Caribbean States, and 25 are from Western European and other States. Information available at the ICC's web presence, cf $<$ http://www.icccpi.menus/asp/states $\% 20$ parties $/$ the $\% 20$ states $\% 20$ parties $\% 20$ to $\% 20$ the $\% 20$ rom e $\% 20$ statute?lan $=$ en-GB $>$ accessed 16 November 2011.

${ }^{3}$ Read BBC, 'African Union in rift with court' BBC (3 July 2009) <http://news.bbc.co.uk/2/hi/8133925.stm> accessed 14 June 2011.

${ }^{4}$ Read David Greenberg, 'African Union Declaration Against the ICC Not What it Seems' Citizens for GlobaßSolutions[44 August 2009)

$<$ http://archive2.globalsolutions.org/in_the_news/african_union_declaration_against_icc_not_what _it_seems_recently_published_foreign_policy_focus> accessed 13 June 2011. In addition, Uganda
} 
the few African countries to have prosecuted cases related to genocide, war crimes and crimes against humanity and moreover has the experience in terms of cooperation of an ad-hoc tribunal (International Criminal Tribunal for Rwanda), it should be noted that Rwanda has not ratified the Rome Statute.

The division among African states on the ICC's cooperation should not preclude Rwanda's ratification of the Rome Statute as this paper attempts to demonstrate.

This paper also attempts to explore both political and legal considerations which should be the basis for Rwanda's ratification of the Rome Statute. Indeed, one cannot separate the two considerations as far as international law is concerned.

\section{Political considerations}

Rwanda's argument to not be a party to the Rome Statute is that the ICC is made to target poorest countries. ${ }^{5}$ It might be argued that Rwanda's position is based on the fact that ICC has so far indicted individuals from African States. ${ }^{6}$ However, this argument is flawed in a way that Uganda, the Democratic Republic of the Congo and the Central African Republic - have referred situations occurring on their territories to the Court. In addition, it is worth noting that Côte d'Ivoire, which is not party to the Rome Statute, had accepted the jurisdiction of the ICC on 18 April 2003; more recently, and on both 14 December 2010 and 3 May 2011, the Presidency of Côte d'Ivoire reconfirmed the country's acceptance of this jurisdiction. On 3 October 2011, Pre-Trial Chamber III granted the Prosecutor's request for authorisation to open investigations proprio motu into the situation in Côte d'Ivoire with respect to alleged crimes within the jurisdiction of the Court, committed since 28 November 2010, as well as with regard to crimes that may be

\footnotetext{
hosted in June 2010 a review conference on the Rome Statute. In this conference African States reiterated their cooperation with the ICC. Interestingly, other African States have ratified the Rome Statute subsequent to the AU Declaration against the ICC. These countries are Seychelles (10th August 2010) Tunisia, (22nd June 2011) and Cape Verde (11 October 2011). The information on the latest African States to ratify the Rome Statute is available at the ICC's web presence, see $<$ http://www.icc-cpi.int/Menus/ASP/states+parties/African+States/> accessed 16 November 2011.

${ }^{5}$ Read Rwanda News Agency, 'Kagame advises Kenya against ICC Justice' Rwanda News Agency (13 September 2009)

$<$ http://www.rnanews.com/index.php?option=com_content\&task=view\&id=1919\&Itemid=29> accessed 14 June 2011. Read also David Kezio-Musoke, 'Kagame tells why he is against ICC charging Bashir' African Press International (5 August 2008)

$<$ http://africanpress.wordpress.com/2008/08/05/kagame-tells-why-he-is-against-icc-chargingbashir/> accessed 14 June 2011.

${ }^{6}$ The ICC is currently focused at different stage of the proceedings (pre-trial and trial depending on individual case) on the situation of six African countries, namely Sudan, Uganda, Central African Republic, Libya, Kenya and the Democratic Republic of Congo.
} 
committed in the future in the context of this situation. ${ }^{7}$ In addition, the Security Council has referred the situation in Libya and Darfur, Sudan - both non States Parties. ${ }^{8}$

As far as Rwanda is concerned, it is worth noting that Rwanda never made any objection on the transfer of a Rwandan citizen to the ICC custody for a trial. Indeed, Callixte Mbarushimana one of the leader of the Forces Democratiques pour la Liberation du Rwanda (an armed rebel group operating in the Democratic Republic of Congo) was transferred from France to the ICC for crimes he had allegedlycommitted in the Democratic Republic of the Congo, the Rwandan Government never made any objection to such transfer but rather welcomed the move. ${ }^{9}$

I could submit that African States have started arguing that the ICC targets poor countries subsequent to the indictment of Omar Al-Bashir, the President of Sudan. Prior to the indictment of Omar Al-Bashir, such argument from African States was not put forward.

As the argument goes, should one follow and adhere to the incoherence of African States, one would conclude that the ICC does not target African countries when indicting an opposition leader or rebel movement leader of a given African country and will be accused of targeting African States when indicting serving head of states or government or their allies.

It could be argued that Rwanda refusal to sign and subsequently ratification of the Rome Statute is due to the fact that it had its troops in the Democratic Republic of the Congo (DRC) and ultimately it feared that its troops could be subject to the ICC jurisdiction. Such argument is flawed because Uganda also had its troops in the DRC but still ratified the Rome Statute.

In addition, Rwanda has made its commitment in the fight against impunity through the prosecution of the 1994 genocide by establishing the Gacaca Courts and other subsequent laws. ${ }^{10}$ Impunity can be defined as the failure to bring perpe-

\footnotetext{
7 The information on the situation of Cote d'Ivoire is available at the ICC's web presence, see <http://www.icccpi.int/Menus/ICC/Situations+and+Cases/> accessed 16 November 2011.

8 Information on situation and cases is available at the ICC's web presence, see ibid. Read also the United Nations Security Council (UNSC) Resolution 1973 on Libya, UNSC Res. 1973(2011), 17 March 2011, S/RES/1973(2011).

${ }^{9}$ Kagire (n 1$)$.

10 United Nations General Assembly through the resolution A/RES/51/114 of 7 March 1997 acknowledged the commitment of the Government of Rwanda in the fight against humanity. Also International Crisis Group, 'Five years after the genocide in Rwanda: Justice in question' ICG Report Rwanda No 1 (7 April 1999) <http://www.crisisgroup.org/en/regions/africa/centralafrica/rwanda/001-five-years-after-the-genocide-in-rwanda-justice-in-question.aspx $>$ accessed 25 June 2012. Inkiko Gacaca, 'The Objectives of Gacaca' <http://www.inkikogacaca.gov.rw/En/EnObjectives.htm> accessed 2 June 2011. As Kaley Nash observed in the aftermath of the Genocide, the Rwandan Government has rightly stated that the adherence to the rule of law and reconciliation of law could not be reached in Rwanda without the fighting against impunity. For more discussion, read Kaley Nash, 'A comparative analysis of Justice in post genocidal rwanda: Fostering a sense of peace and reconciliation? (2007) 1(1) Africana <http://www.africanajournal.org/PDF/vol1/vol1_4_Kaley\%20Nash.pdf> accessed 3 July 2011.
} 
trators of human rights violations to justice. It denies the victims their right to justice and redress. ${ }^{11}$ Furthermore, Rwanda is also a party to the Great lakes Protocol on Genocide, War crimes and Crimes against Humanity and all forms of Discrimination. In light of the above, the ratification of the Rome Statute will only reaffirm the commitment of Rwanda in the fight against humanity.

\section{Legal Considerations}

The Rome Statute covers international crimes namely genocide, war crimes, crimes against humanity and crime of aggression. Save the crime of aggression, the crimes covered by the Rome Statute are provided in different instruments to which Rwanda is a Party.

Thus, Rwanda is a party to the Convention on the Prevention and Punishment of Genocide, known as the 'Genocide Convention'.12 The Genocide Convention obliges States parties to punish people who have committed genocide whether in time of peace or war (article 1) to punish Persons committing genocide or any of the other acts irrespective of their constitutional status (article 4) and to enact, in accordance with their respective Constitutions, the necessary legislation to give effect to the provisions of the present Convention, and, in particular, to provide effective penalties for persons guilty of genocide.

Rwanda is also a party to the Geneva Conventions. ${ }^{13}$ There is no dispute on the crucial role the ICC plays in the enforcement of the Geneva Conventions since the ICC has jurisdiction on people responsible for the violation of international humanitarian law as provided under the Geneva Conventions. ${ }^{14}$

As far as the prosecution for the violation of the Geneva Conventions is concerned, The First Geneva Convention relating to the Amelioration of the Condition of the Wounded and Sick in Armed Forces in the Field (art 49); The Second Geneva Convention relating to the Amelioration of the Condition of Wounded,

\footnotetext{
11 Amnesty International, 'End Impunity for Human Rights Violations.'

<http://www.amnesty.ie/our-work/end-impunity-human-rights-violations> accessed 3 July 2011.

12 Rwanda ratified the Convention on the Prevention and Punishment of the Crime of Genocide on 16 April 1975.

13 The Four Geneva Conventions which Rwanda ratified on 5 May 1964 are the Convention (I) for the Amelioration of the Condition of the Wounded and Sick in Armed Forces in the Field, 74 UNTS 970, 12 August 1949, entered into force 21 October 1950; on 5 May 1964 the Convention (II) for the Amelioration of the Condition of Wounded, Sick and Shipwrecked Members of Armed Forces at Sea, 75 UNTS 971, 12 August 1949, entered into force 21 October 1950; on 5 May 1964 the Convention (III) relative to the Treatment of Prisoners of War, 75 UNTS 972, 12 August 1949, entered into force 21 October 1950 and on 5 May 1964 the Convention (IV) relative to the Protection of Civilian Persons in Time of War, 75 UNTS 973, 287, 12 August 1949, entered into force 21 October 1950.

14 See Anne-Marie La Rosa, 'ICRC and ICC: two separate but complementary approaches to ensuring respect for international humanitarian law' (3 March 2009)

$<$ http://www.icrc.org/eng/resources/documents/interview/international-criminal-court-interview101008.htm> accessed 5 July 2011.
} 
Sick and Shipwrecked Members of Armed Forces at Sea. (art 50); The Third Geneva Convention relating to the Treatment of Prisoners of War (art 129); The Fourth Geneva Convention relative to the Protection of Civilian Persons in Time of War (art 146); The Additional Protocol to the Geneva Conventions of $12 \mathrm{Au}$ gust 1949, relating to the Protection of Victims of International Armed Conflicts (Protocol I), 8 June 1977 (art 88). The Geneva Conventions oblige States to either prosecute or extradite people who are responsible for the breach of the Geneva Convention.

Rwanda also is a party to the Convention on the Non-Applicability of Statutory Limitations to War Crimes and Crimes against Humanity of 26 November 1968. ${ }^{15}$ Both the Rome Statute ${ }^{16}$ and the Convention of the non-applicability of Statutory Limitations on War Crimes and Crimes against Humanity have a common aim of fighting against impunity. Therefore, the ratification of the Rome Statute complements the Convention on the non-applicability of Statutory Limitations on War Crimes and Crimes against Humanity in a way that, crimes which fall under the Rome Statute are not subject to statutory limitations.

Rwanda is a party to the Pact on Security, Stability and Development in the Great Lakes Region, especially its Protocol for the Prevention and the Punishment of the Crime of Genocide, war Crimes and Crimes against Humanity and all forms of Discrimination. The relevance of this protocol will be discussed further.

To conclude, the above mentioned legal instruments ratified by Rwanda are to influence Rwanda to ratify the Rome Statute since they cover for crimes which fall under the Rome Statute and moreover the previous ratification of these instruments demonstrates the commitment of Rwanda in fighting against humanity through the prosecution of genocide, war crimes and crimes against humanity which also are provided under the Rome Statute.

\section{Legal implications}

The ratification of the Rome Statute has many legal implications, thus there is a need to explore these implications should Rwanda ratify the Rome Statute. The first and most implication of the ratification of the Rome Statute will be the compliance of Rwanda to the Rome Statute in performing it in good faith. ${ }^{17}$

\subsection{The Acceptance of the Jurisdiction of the ICC}

The first implication of the ratification will oblige Rwanda to accept the jurisdiction of the ICC on the following:

\footnotetext{
${ }^{15}$ Rwanda ratified this Convention on 16 April 1975.

16 Article 29 of the Rome Statute provides for Non-Applicability of Statute Limitations.

17 Vienna Convention on the Law of Treaties, 1155 UNTS 331, 23 May 1969, entered into force 27 January 1980, art 26.
} 


\subsubsection{The Jurisdiction of the ICC}

The Rome Statute grants the ICC jurisdiction to try individuals for genocide, war crimes and crimes against humanity.

\subsubsection{Jurisdiction ratione materiae of the ICC}

As far as the Rome Statute is concerned, the subject matter or jurisdictions ratione materiae of the ICC is the following: genocide, crimes against humanity, war crimes, crime of aggression. ${ }^{18}$

With regard to Rwanda's legislation, it is worth noting that Rwanda has enacted law on genocide, war crimes and crimes against humanity and therefore Rwandan courts have jurisdiction over these international crimes. ${ }^{19}$ However, it must be noted that article 5 of the Law $N^{\circ} 33$ bis/2003 repressing the crime of genocide, crimes against humanity and war crimes provides a restrictive definition of the crime against humanity as follow:

The crime against humanity shall mean one of the following acts committed within the context of a widespread or systematic attack directed against the civilian population because of their nationality, political opinions, ethnic or religious origins:

The criteria of nationality, political opinions, ethnic or religious origins are not included in the definition of crimes against humanity under the Rome Statute, the Statute of the International Criminal Tribunal for the Former Yugoslavia and the International Criminal Tribunal for Rwanda. Thus, there is a need for Rwanda to amend its definition on crimes against humanity since the definition of crimes against humanity is in conflict with the Rome Statute since it is very restrictive.

To conclude, as far as the subject matter of the jurisdiction ratione materiae of the ICC is concerned, Rwanda's ratification of the Rome Statute will imply that Rwanda accepts the ICC jurisdiction on genocide, crimes against humanity, war crimes and crime of aggression if committed in Rwanda by Rwandans and perpetrators who are on the Rwandan soil.

\subsubsection{Jurisdiction ratione temporis of the ICC}

As far as the Rome Statute is concerned, the ICC has jurisdiction only with respect to crimes committed after the entry into force of the Statute. ${ }^{20}$ The Statute has

\footnotetext{
${ }^{18}$ Rome Statute, art 5. As far as the crime of aggression is concerned, there is no consensus among States Parties on the scope of this crime.

${ }^{19}$ Law N ${ }^{\circ} 33$ bis/2003 Repressing the crime of genocide, crimes against humanity and war crimes. 6 September 2003 (Law No 33 bis/2003).

20 Rome Statute, art 11(1).
} 
come into force in July 2002. In case of Rwanda, the ICC could have jurisdiction for crimes committed after the ratification. ${ }^{21}$

\subsubsection{Jurisdiction ratione loci of the ICC (territorial jurisdiction)}

As far as the ICC jurisdiction of ratione loci (territorial jurisdiction) is concerned it should be noted that this type of jurisdiction is limited over the territories of States Parties and the vessels and aircraft registered in States Parties, unless that the crime was committed by a national of a State Party or a non-State Party has made a declaration or special agreement to accept the exercise of jurisdiction by the ICC with respect to the crime. ${ }^{22}$ Nevertheless, the ICC can have a jurisdiction in a non State Party through the United Nations Security Council situation referral to the Prosecutor of the ICC. ${ }^{23}$ Libya and Sudan are the case studies of Non-States Parties to which the ICC has investigated and issued arrest of warrant for crimes committed in Sudan and Libya.

Should Rwanda ratify the Rome Statute, the ICC will have jurisdiction on crimes committed in Rwanda. This will not be the first time, an international tribunal will have jurisdiction on crimes committed in the territory of Rwanda. Indeed, the International Criminal Tribunal for Rwanda has jurisdiction on crimes committed in Rwanda as stipulated in its statute.

\subsubsection{Jurisdiction ratione personae of the ICC}

The Rome Statute provides for individual criminal responsibility ${ }^{24}$ but makes an exception for people who were under 18 years of age at the time the alleged crimes was committed. ${ }^{25}$

The nationality of the accused is irrelevant as far as individual criminal responsibility is concerned. At this stage, though Rwanda is not a party to the Rome Statute, the ICC cannot be prevented from prosecuting a Rwandan national for crimes falling under the Rome Statute. The case of Callixte Mbarushimana illustrates this statement. As previously mentioned, he is the only Rwandan citizen to have a case to answer at the ICC though is not a State Party on the ground that he committed crimes in the Democratic Republic of Congo.

\subsection{Implementing legislation}

The ratification of the Rome Statute requires States Parties to enact laws which gives effect to the Rome Statute, put it differently a law which implements the

\footnotetext{
21 Ibid art 11(2).

22 Ibid arts 4 and 12.

23 Ibid art 13(b).

24 Ibid art 25.

25 Ibid art 26.
} 
Rome Statute. As far as Rwanda is concerned, Rwanda can only enact such law upon the ratification of the Rome Statute. Rwanda being a Monist State, the Rome Statute will become an integral part of the domestic law. ${ }^{26}$

The fact that the Constitution provides that international treaties or convention ratified by Rwanda become automatically an integral part of the domestic law, nothing prevents Rwanda from enacting a law implementing the Rome Statute which will provide for co-operation as experienced in other African monist states. $^{27}$

\subsection{Co-operation (and surrender)}

\subsubsection{Co-operation}

As far as co-operation between the ICC and States Parties is concerned, it should be noted that article 86 makes the co-operation compulsory. The compulsory nature of the co-operation between States Parties and the ICC is very crucial since the ICC does not have a police or any security apparatus to carry out investigation and subsequently arrest of suspects.

In addition, the Rome Statute under its article 87 provides for request of the State for co-operation. To give effect to the co-operation from States Parties, article 87(7) of the Rome Statute reads as follow:

Where a State Party fails to comply with a request to cooperate by the Court contrary to the provisions of this Statute, thereby preventing the Court from exercising its functions and powers under this Statute, the Court may make a finding to that effect and refer the matter to the Assembly of States Parties or, where the Security Council referred the matter to the Court, to the Security Council.

Article 88 of the Rome Statute obliges States to ensure that there are in place procedures enabling all forms of co-operations. ${ }^{28}$ Should Rwanda ratify the Rome Statute there will be a need to set up in place procedures for co-operation purpose. It could be argued that Rwanda will not face many challenges in this regard since it has a previous experience in terms of co-operation with the ICTR, though the cooperation faced some challenges in the past. The in-depth analysis of the challenges and achievements of the co-operation between the ICTR and Rwanda is beyond the scope of this paper.

\footnotetext{
${ }^{26}$ Constitution of the Republic of Rwanda, 4 June 2003 (Constitution of Rwanda), art 189.

27 Benin, Burkina Faso, Burundi, Republic of Congo (Brazzaville), the Democratic Republic of Congo, Gabon, Mali have enacted draft bill implementing the Rome Statute despite the fact they belong to they all are monist states. The ratification of the Rome Statute would have been enough as far as implementation is concerned, but they opted for drafting a bill implementing the Rome Statute.

28 Art 88 reads: 'States Parties shall ensure that there are procedures available under their national law for all of the forms of cooperation which are specified under this Part.'
} 


\subsubsection{Surrender}

As one of the components of the co-operation between States Parties and the ICC, arrest and surrender need to be discussed. Arrest and surrender are one of the most important components of the Rome Statute with regard to co-operation since the ICC does not have a police to make arrest of suspects. ${ }^{29}$

The Rome Statute makes a clear distinction between surrender and extradition in providing as follow:

(a) "surrender" means the delivering up of a person by a State to the Court, pursuant to this Statute.

(b) "extradition" means the delivering up of a person by one State to another as provided by treaty, convention or national legislation. ${ }^{30}$

Should Rwanda ratify the Rome Statute, then Rwanda will be under the obligation to arrest and surrender individuals to whom the ICC has established a prima facie case against them. With regard to arrest, immunity might arise as a serious issue.

\subsection{Cooperation with the ICC}

Like other international criminal tribunals, the Rome Statute establishing the ICC excludes immunity. Immunity has been an obstacle under domestic law. ${ }^{31}$ As far as Rwanda is concerned, it is worth noting that Rwanda has enacted a law on Genocide, War crimes and Crimes against humanity which excludes immunity for these crimes. ${ }^{32}$ In addition, Rwanda's Gacaca courts have also excluded immunity. Nevertheless, the only issue which can jeopardize the co-operation between Rwanda and the ICC in terms of arrest of suspect is the Bilateral Immunity Agreement between the US Government and Rwanda. ${ }^{33}$ Under this Bilateral Immunity Agreement, Rwanda cannot surrender a US national to the ICC.

With regard to surrender, the Constitution of Rwanda prohibits the extradition of a Rwandan national. ${ }^{34}$ As previously discussed, the ICC provides for 'surrender' and it should be noted that the Constitution is silent on 'surrender'. Can Rwanda still refuse to 'surrender' its national to the ICC in referring to its Constitution? The Constitution of Rwanda is not the only one which prohibits the extradition of its nationals. Indeed many constitutions do the same.

\footnotetext{
${ }^{29}$ Art 89 of the Rome Statute provides for surrender of persons to the ICC.

30 Rome Statute, art 102.

31 For further discussion, Chacha Bhoke Murungu, 'Immunity of State officials from Prosecution for International Crimes: Law and Practice in Africa' in Chacha Bhoke Murungu and Japhet Biegon (eds), Prosecuting International Crimes in Africa (Pretoria University Law Press 2011).

32 Law N 33 bis/2003, art 18.

33 The Bilateral Agreement was signed between Rwanda and the US Government on 4 March 2003.

34 Constitution of Rwanda, art 25(2).
} 
In order to overcome the constitutional limitation on extradition, some States have enacted laws derogating extradition of Finland Citizens to the ICC. Colombia incorporated the Rome Statute into its Constitution. Other countries ratified the Rome Statute without amending their constitution. ${ }^{35}$

There are other arguments which suggest that Rwanda can 'surrender' its nationals for crimes falling under the Rome Statute. Rwanda is a Party to The Pact on Security, Stability and Development in the Great Lakes Region which serves as a legal framework and an agenda of the ICGLR with the aim of creating the conditions for security, stability and development between the member states. It was adopted by the Heads of state and government of the International Conference on the Great Lakes Region (ICGLR) member states in Nairobi in December 2006 and entered into force in June 2008. The Pact includes 10 Protocols and 4 programmes of action with 33 priority projects. ${ }^{36}$ One of its protocol known as Protocol for the Prevention and the Punishment of the Crime of Genocide, war Crimes and Crimes against Humanity and all forms of Discrimination requires some specific attention.

Indeed, article 14 of the Protocol for the Prevention and the Punishment of the Crime of Genocide, war Crimes and Crimes against Humanity and all forms of Discrimination provides for extradition as follow:

1. Crimes within the field of application of this Protocol shall be extraditable. Member States shall include these crimes in any extradition treaty applicable to them.

2. A Member State which receives a request for extradition from another Member State which has not concluded an extradition treaty with the requested Member State may consider this Protocol as a legal basis for requesting extradition, as long as the crimes in respect of which such extradition is sought are within the field of application of this Protocol.

3. Member States which do not subject the execution of an extradition measure to the existence of an extradition treaty shall recognise that the crimes covered by this Protocol shall be extraditable.

4. For purposes of extradition, the crime of genocide, war crimes, and crimes against humanity shall not be considered as political crimes to which the exception of political offences apply in matters of extradition.

From the above provision, it could be argued that Rwanda was aware of the legal consequences as far as crimes covered in this protocol are extraditable. Should

\footnotetext{
35 Paul Tavernier, 'Comment surmonter les obstacles constitutionnels a la ratification du Statut de Rome de la Cour Pénale Internationale' <http://www.rtdh.eu/pdf/2002545.pdfa> accessed 5 July 2011.

36 The information is available at the web presence of the International Conference on the Great Lakes Regions <http://www.icglr.org/spip.php?article2> accessed 14 June 2011.
} 
Rwanda felt the terrible consequences of this provision, it should have made a reservation on this regard.

Furthermore, the Protocol under its article 24 provides for the co-operation with the ICC as follow:

1. If a Member State receives a request from the International Criminal Court for the surrender of an indicted person and a competing request from another State to extradite the same person for the same crime, the requested Member State shall give priority to the request of the International Criminal Court.

2. The status of the national of the requested State shall not constitute a bar to the hand over or surrender of such a national.

\subsection{Complementarity}

As far as the relationship between the International Criminal Tribunal for the Former Yugoslavia (ICTY) and the International Criminal Tribunal for Rwanda (ICTR) and domestic jurisdiction is concerned, the United Nations Security Council decided to vest both tribunals with what was called 'concurrent jurisdiction' coupled with a 'primacy clause' in order to solve the problem of linkage between domestic and international jurisdiction. It is argued that the primacy given to these tribunals gave rise to much controversy, since States felt that their sovereignty was being eroded. ${ }^{37}$

In light of the above, Mark Benzing has rightly observed: 'The principle of complementarity has been described as essential for the acceptance of the Statute by States.'38 The most distinctive feature of the International Criminal Court is the complementarity between the ICC as national criminal jurisdictions has been described as the most distinctive features of the ICC. ${ }^{39}$ Article 1 of the Rome Statues provides for complementarity between national jurisdictions and the ICC.

Under the principle of complementarity, the ICC will not investigate or prosecute if a State Party is already investigating or prosecuting the same case. The ICC only exercises its jurisdiction and intervenes in cases where national courts are unable or unwilling to initiate or conduct their own proceedings. The Court deter-

\footnotetext{
37 Oscar Solera, 'Complementary jurisdiction and international criminal justice' (2002) 84(845) International Review of the Red Cross 145 ff. <http://www.icrc.org/eng/assets/files/other/145-172solera.pdf> accessed 4 July 2011.

38 Mark Benzing, 'The complementarity regime of the International Criminal Court: International Criminal Justice between State Sovereignty and the Fight Against Immunity' (2003) 7 Max Planck Yearbook of United Nations Law 591-632.

39 The implementation of the Rome Statute of the International Criminal Court in African Countries is available at the web presence of the Institute for Security Studies <http://www.issafrica.org/cdromestatute/pages/document.pdf> accessed 20 July 2011.
} 
mines if the country has adequate resources, a functioning judicial system and whether the investigation, prosecution or trial is fair. ${ }^{40}$

Putting it differently, the principle of complementarity translates the principle of 'aut dedere, aut judicare' which requires States under international law to either prosecute or extradite an individual for international crimes. Indeed, the ratification and subsequent implementation of the Rome Statute is in line with the principles of 'aut dedere, aut judicare' which means the obligation of either to extradite or prosecute. ${ }^{41}$ Like other States Rwanda is under duty to prosecute perpetrators of gross human rights violations. ${ }^{42}$

Should Rwanda ratify the Rome Statute, its sovereignty as a State will not be undermined since Rwanda as other States Parties to the Rome Statute will be given the priority to prosecute those international crimes as provided under the Rome Statute.

Rwanda's is the only African country to have experienced the trial of its citizens in a big number by both the International Criminal Tribunal and foreign jurisdictions on international crimes allegations.

Universal jurisdiction is a criminal jurisdiction based solely on the nature of the crime, without regard to where the crime was committed, the nationality of the alleged or convicted perpetrator, the nationality of the victim, or any other connection to the state exercising such jurisdiction. ${ }^{43}$

As far as the exercise of universal jurisdiction is concerned, Rwanda has shown mixed feelings. Subsequent to the Rwandan genocide, many foreign jurisdictions have exercised universal jurisdiction on Rwandan citizens accused of genocide, crime against humanity and war crimes grounds. ${ }^{44}$

Indeed, Rwanda will not theoretically have any problems in trying a foreigner alleged to have committed the mentioned crimes if found in Rwanda pursuant to Article 90 of Organic Law (Statute Act)N51/2008 of 09/09/2008 determining the

\footnotetext{
40 The American Non-Governmental Organizations Coalition for the International Criminal Court, 'Safeguards and Protections for Military and Diplomatic Officials under the Rome Statute' (26 August $2009)<$ http://www.amicc.org/docs/Safeguards_and_Protections_in_Rome_Statute.pdf> accessed 4 July 2011.

${ }^{41}$ Cherif Bassiouni and Edward M Wise, Aut Dedere Aut Judicare: The Duty to Extradite or Prosecute in International Law (Dordrecht; Martinus Nijhoff Publishers 1995) 3; Michael Plachta, 'Aut Dedere Aut Judicare: An Overview of Modes of Implementation and Approaches' (1999) 6 Journal of European and Comparative Law 4, 332.

42 Martha Minow, Between Vengeance and Forgiveness: Facing History after Genocide and Mass Violence (Beacon Press 1998) 28.

43 Program in Law and Public Affairs and Woodrow Wilson School of Public and International Affairs, Princeton University and others, Princeton Principles on Universal Jurisdiction (2001) $<$ http://www.law.uc.edu/institutes-centers/urban-morgan-institute/princeton-principles-universaljurisdiction> accessed 20 June 2012.

44 These countries include Belgium, Canada, France, Finland, Spain and Norway. Read also Federation Internationale des Droits de l'Homme, 'African Union should respect and support Universal Jurisdiction’ (4 February 2009) <http://www.fidh.org/African-Union-should-respect-and-support> accessed 14 June 2011.
} 
Organization, Functioning and Jurisdiction of Courts grants to the High Court the exercise of Universal Jurisdiction. Article 90 (1) provides:

The High Court shall have jurisdiction to try any person including nonnationals, non government associations or organizations whether national or foreign, alleged to have committed, within or outside the territory of Rwanda, any crimes falling within the category of international or crossborder crimes especially, terrorism, hostage taking, drug trafficking, arms trafficking, money laundering, theft of motor vehicles for sale abroad, human trafficking especially of young children, slavery and other crimes of similar nature.

Though the above provision is a clear violation of universal jurisdiction because it includes crimes which do not fall under international crimes, it should be noted that the 'broad' scope of this provision enables the High Court to try foreigners who have committed crimes which fall under the Rome Statute.

In light of the above, the trial of Rwandan nationals by the ICC will not be the first case of Rwandan citizens being prosecuted by an international court and moreover outside the territory of Rwanda. ${ }^{45}$

As previously mentioned, the Constitution of Rwanda prohibits extradition of Rwandan nationals; it is worth noting that there is a precedent which supports the contrary. Indeed, Rwanda extradited three of its nationals for alleged murder of American tourists. ${ }^{46}$ Not only this extradition was in violation of the Constitution, the Rwandan law is very silent on extradition since there is no single provision dealing for extradition of foreigners such as the court which has a jurisdiction on extradition matter.

\section{Conclusion}

The paper attempted to explore all arguments which are either against or in interests of Rwanda's ratification of the Rome Statute establishing the ICC. In light of the pros and cons, the paper came to the conclusion that Rwanda needs to ratify the Rome Statute and thus becomes bound to the ICC due the fact legal and political considerations suggest that it is for Rwanda's interest as far its commitment in the fight against impunity is concerned, bearing in mind that impunity was one the reasons of the 1994 Rwandan genocide.

\footnotetext{
45 Rwandan nationals have been subjected to the jurisdiction of the International Criminal Tribunal for Rwanda and other western countries namely Belgium, Finland, Canada, France, Finland and the United States of America.

46 Tom Henry, 'US Judge rules Rwanda murder confessions coerced by torture' $<$ http://jurist.law.pitt.edu/paperchase/2006/08/us-judge-rules-rwanda-murder.php $>$ accessed 6 June 2011.
} 



\title{
L'impact de la peine de mort dans le processus de l'adoption de la loi de mise en ouvre du statut de Rome en République Démocratique du Congo
}

\author{
Lievin Ngondji Ongombe
}

\section{Résumé}

La République Démocratique du Congo est parmi les pays ayant signé et ratifié le Statut de Rome de la Cour Pénale Internationale et dont environ quatre de ses ressortissants sont jugés à La Haye. Il importe donc qu'au regard de son contexte particulier en rapport avec la commission des crimes internationaux sur son territoire et l'implication de la Cour Pénale Internationale, que sa législation soit adaptée ce droit particulier pour permettre à la justice nationale de juger les personnes poursuivies pour ces crimes graves.

Mais, la question de la peine de mort est d'un tel enjeu que tout est fait pour ne pas consacrer formellement son abolition en droit Congolais, même s'il faut sacrifier les accords et traités internationaux librement signés et ratifiés

Cet enjeu consiste notamment à la nécessité de ne pas gêner le Président de la République Démocratique du Congo, en le contraignant à adoucir le sort des personnes condamnées à mort et parmi elles, elles assassins de feu Président Laurent Désiré Kabila, son défunt père et prédécesseur. Il faut aussi éviter de faire la part belle aux auteurs des crimes internationaux accusés d'avoir semé la mort impunément à l'Est du pays. Il s'agirait particulièrement des différents mouvements rebelles qui auraient bénéficié du soutien du Rwanda (RCD) et de l'Uganda (RCD K-ML, MLC).

La majorité parlementaire avait balayé d'un revers de la main la proposition deloi sur l'abolition de la peine de mort soumise à l'Assemblée Nationalepar un député du Parti Rassemblement Congolais pour la Démocratie (RCD). Certains députés ont affirmé que ce n'était qu'une 
question renvoyée aux débats de la proposition de loi de mise en cuvre du statut de Rome qui était alors en examen devant le même parlement et qui, parmi les peines qu'elle prévoit, exclue la peine de mort.

Cet article se propose expliquer comment l'inéluctable débat sur la peine de mort faité luder l'examen de la proposition de loi de mise en cuvre du Statut de Rome et de montrer que pareille politique dessert plutôt la République Démocratique du Congo dans la mesure où elle génère des contradictions inacceptables dans l'économie générale du droit pénal congolais.

\title{
The impact of the death penalty in the process of adopting the law implementation of the Rome Stat- ute in the Democratic Republic of Congo
}

\begin{abstract}
The Democratic Republic of Congo is among the countries that have signed and ratified the Rome Statute of the International Criminal Court and thus about four of its nationals have been tried in The Hague. It is therefore important, given the particular framework in relation to the commission of international crimes on its territory and the involvement of the International Criminal Court, that its legislation is adapted as regards this particular right to allow national justice to try those prosecuted for these serious crimes.

However, the question of the death penalty is so challenging that everything has been done to avoid formally applying its abolition under Congolese law, even if this means sacrificing the international agreements and treaties freely signed and ratified.

This issue includes the need not to inconvenience the President of the Democratic Republic of Congo, forcing him to ease the plight of those sentenced to death - among them, the assassins of the late President Laurent Désiré Kabila, his father and predecessor. We must also avoid placing the spotlight on those who have international crimes who are accused of having sown death with impunity in the east of the country. This would mean especially the various rebel movements that have received support from Rwanda (RCD) and Uganda (RCD K-ML, MLC).

The parliamentary majority brushed aside the bill on the abolition of the death penalty submitted to the National Assembly by a member of the Rally for Congolese Democracy (RCD). Some MPs said that it was only a matter referred to the debates of the bill implementing the Rome Statute that was then examined by the same parliament and among the penalties it provided, excluded the death penalty.

This article aims to explain how the inevitable debate on the death penalty is evading review of the bill implementing the Rome Statute and to show that such a policy serves instead the Demo-
\end{abstract}


cratic Republic of Congo to the extent that it generates unacceptable contradictions in the general economy of the Congolese criminal law.

\section{Introduction}

L'année 1990 marque le point de départ d'une nouvelle ère en Afrique, celle de la démocratisation.

La liberté d'expression qu'implique ce système de gouvernement a été mal interprétée au Zaïre d'alors. Certains zaïrois prendront la liberté d'exprimer ouvertement leur haine envers leurs compatriotes. Ce sera le mouvement d'épuration ethnique qui affectera les provinces du Katanga et du Kivu. Apportées dans ces provinces pour renforcer la main d'œuvre à l'époque coloniale, les non originaires seront vite accusés de voler le travail et le bien être social des originaires. Ce mouvement datait déjà des années 1960 au lendemain de l'indépendance, mais il a su être maté par le régime Mobutu notamment grâce a la territoriale des non originaires considérée comme facteur d'unité nationale.

Les épurations ethniques du Katanga et du Kivu seront l'occasion de la commission sur une grande échelle d'actes de violence rentrant dans la catégorie des crimes internationaux. Ces actes feront plus de 500.000 morts et plus de 3 millions de déplacés; mais ne connaitront aucune réponse pénale faute de législation appropriée tant sur le plan national que sur le plan international. Malgré les nombreux appels des ONG de défense des droits de l'homme, le Conseil de Sécurité des Nations Unies, dans sa discrétion, ne jugera pas nécessaire d'instituer un Tribunal Pénal International Pour la RD Congo comme il l'aura fait pour l'ex Yougoslavie et le Rwanda.

Tant et si bien qu'a ce jour l'on recherche encore des réponses à apporter à ces crimes internationaux. C'est dans ces conditions qu'abouti (avec l'adoption du traite de Rome portant statut de la Cour Pénale Internationale) la longue marche vers l'établissement d'une justice pénale internationale permanente.

La République Démocratique du Congo fut, faut il le souligner l'un des pays dont la ratification permit l'entrée en vigueur de la CPI.

L'engagement de la RD Congo en matière de justice pénale internationale est remarquable. La ratification du statut de Rome ${ }^{1}$ et la signature de l'accord de coopération entre cette juridiction et la $\mathrm{RD} \mathrm{Congo}^{2}$ en témoignent à suffisance. Néanmoins, il reste indispensable d'harmoniser le droit pénal substantiel avec le statut de la CPI. C'est depuis 2005 que les initiatives (pourtant considérables) prises dans ce sens peinent à aboutir.

${ }^{1}$ Décret-loi n ${ }^{\circ} 003 / 2002$.

2 Ibid. 
Cet essai se propose de décrypter les causes de ce patinage et de suggérer des pistes de sortie. A cet effet, il s'appesanti sur le frein relatif a la peine de mort. C'est pourquoi, après un bref aperçu sur la situation de la peine de mort en RD Congo (2), il circonscrit la nécessité d'harmonisation du droit congolais avec le statut de Rome (3), revient sur les efforts législatifs en vue de ladite harmonisation (4), et relate les circonstances dans lesquelles la question de la peine de mort a eu raison des efforts législatifs en vue de la mise en œuvre du statut de Rome en RDC (5).

\section{Situation de la peine de mort en RD Congo}

La peine de mort est prévue tant par le code pénal ordinaire ${ }^{3}$ que par le code pénal militaire. ${ }^{4}$ Néanmoins, en vertu de la loi n024-2002 portant code pénal militaire qui contient une expression de l'hésitation du pouvoir congolais de faire le pas définitif vers l'abolition, la RD Congo observe un moratoire quant à l'exécution de cette peine.

Pourtant l'article 27 de cette loi donne une innovation évolutive confirmant la tendance à l'humanisation du droit pénal militaire en prévoyant ce qui suit :

Dans tous les cas punissables de mort, la juridiction militaire pourra prononcer la peine de servitude pénale à perpétuité ou une peine de servitude pénale principale, en précisant une durée minimale de sureté incompressible, c'est-à-dire la période de temps pendant laquelle le condamné ne peut prétendre à aucune remise de peine.

Mais malheureusement cette même loi tout en prétendant, dans son exposé des motifs, 'tenir compte des conventions internationales et autres instruments juridiques sur les droits de l'homme. Cette introduction s'inscrit dans la suite de la ratification par la R.D. Congo du Statut de Rome'.

C'est ainsi par exemple que les personnes condamnées (à mort) comme assassins du président Laurent Désiré Kabila ${ }^{5}$ croupissent encore en prison.

Le statut de Rome dument ratifié par la RD Congo ne reprend pas la peine de mort. Une certaine opinion congolaise estime que de par la ratification du statut de Rome, la peine de mort devrait être abolie en droit congolais en vertu du principe de la primauté des accords internationaux sur le droit national. ${ }^{6}$

\footnotetext{
3 Code Pénal livre $1{ }^{\text {er }}$ art 5.

4 Code Pénal Militaire art 167.

${ }^{5} \mathrm{La}$ nuance est importante à ce sujet. Dans le film 'La vérité sur l'assassinat de Laurent Désiré Kabila', le sénateur Yerodia Abdoulaye Ndombasi (célèbre pour l'affaire du mandat d'arrêt international émis contre lui par un juge belge et jugé illégal par la Cour Internationale de Justice, il est une des figures clés du régime Kabila) affirme que les personnes condamnées pour l'assassinat du Mzee LD Kabila ne font que porter le chapeau. Mais pour les libérer, il faudrait une solution de rechange, il faudrait trouver les vrais assassins.

${ }^{6}$ Ainsi par exemple, la défense de maitre de Me Firmin Yangambi (poursuivi, devant la Cour Militaire de Kinshasa au premier degré et la Haute Cour Militaire en appel, pour atteinte à la sûreté de l'Etat et l'organisation de mouvements insurrectionnels) a soutenu en vain que la peine de mort n'avait plus droit de cité en RD Congo depuis la ratification du statut de Rome. La Haute Cour n'a pas eu égard à
} 
Robert Badinter voit, lui aussi dans le statut de Rome, une victoire pour les abolitionnistes dans la mesure où ce texte ne reprend pas la peine de mort. ${ }^{7}$

Néanmoins, nous sommes d'avis que les opinions auxquelles nous venons de faire allusion se trompent sur la quintessence du statut de Rome en rapport avec la peine de mort. Car l'article 80 semble être un compromis entre abolitionnistes et rétentioniste. Ainsi donc, il n'y aura pas de peine de mort à la CPI mais les états restent libres de l'appliquer chez eux. Et donc, le maintien de la peine de mort dans un Etat partie n'énerve pas le statut de Rome en vertu de la disposition permissive contenue à l'article 80.

Le code pénal militaire édicté à la suite de la ratification du statut de Rome maintient la peine de mort. Mais la constitution du 18 février 2006, actuellement en vigueur, décrète le caractère sacré de la vie humaine. ${ }^{8}$ D'aucuns voient en cette consécration, une abolition de la peine de mort. ${ }^{?}$

ce moyen au motif que la décision de ne pas condamner à la peine capital n'est pas exigée par les dispositions du statut de Rome, puisque son article 80 a au contraire été conçu dans le but de laisser les Etats appliquer leurs peines nationales et la peine capitale en particulier. Cette disposition est le fruit d'un compromis entre les Etats en faveur de l'abolition de la peine de mort et ceux s'y opposent, tels que les pays arabes, certains pays des caraibes, la RDC et même le Rwanda qui vient d'abolir la peine de mort laquelle il militait à l'époque. Ainsi, bien que le statut prévoie comme peine maximale la réclusion à perpétuité, il n'interdit pas aux Etats parties d'appliquer la peine de mort pour les crimes internationaux, si cette peine est prévue dans leur législation nationale.

Par ailleurs, les juges militaires dans les affaires dites de Kilwa et de Songomboyo ont refusé d'appliquer la peine de mort en vertu du statut de la Cour Pénale Internationale. En effet, quelques que soient les solutions adoptées par le droit interne pour régler les conditions d'application directe d'un traité par les juridictions nationales, celles-ci n'affectent en rien le devoir de l'Etat d'en assurer l'application, sous peine d'engager sa responsabilité internationale. Le tribunal militaire de Mbandaka, pour ne citer que lui a motivé sa décision comme suit :

Le tribunal militaire de garnison a été institué par la Loi n ${ }^{\circ} 023 / 2002$ du 18 novembre 2002 portant Code judiciaire militaire tandis qu'il applique les règles de fond prévues par la Loi $n^{\circ} 024 / 2002$ portant Code pénal militaire promulguée la même date; Cependant les crimes contre l'humanité se trouvent réglementés aussi bien par la Loi nº24/2002 précitée que par le Statut de Rome de la Cour pénale internationale du 17 juillet 1998 ; Aux termes de l'article 153, in fine de la Constitution de la République Démocratique du Congo, outre les lois, les juridictions civiles et militaires appliquent également les traités et accords internationaux dûment ratifiés; Dans le cas d'espèce, le crime contre l'humanité imputé aux prévenus est réglementé par deux instruments juridiques en conflit quant à sa définition ; Les traités et accords internationaux régulièrement conclus ont dès leur publication, une autorité supérieure à celle des lois, sous réserve pour chaque traité ou accord, de son application par l'autre partie; A ce principe de règlement de conflit des lois, le Statut de Rome de la CPI est très favorable aux prévenus écartant la peine capitale et dispose des mécanismes protecteurs des victimes efficaces pour être retenu dans le cadre du procès en cours.

${ }^{7}$ Robert Badinter, Travaux du 4ìme Congrès mondial contre la peine de mort (ECPM 2010).

${ }^{8}$ Constitution du 18 février 2006 art 16.

9 Ainsi la défense des assassins du journaliste congolais Franck Ngikye a évoqué la constitution congolaise comme ayant aboli la peine de mort. Mais la Haute Cour militaire n'a pas eu égard à ce moyen au motif que la peine capitale est d'application dans le code pénal militaire de la RDC et donc il faut une loi abolissant la peine de mort. 


\section{Nécessité d'harmonisation du droit congolais avec le statut de Rome}

Au nombre des principes du droit international des traités, il convient de mentionner celui de l'application de bonne foi des engagements internationaux. Ce principe trouve son fondement juridique à l'article 26 de la Convention de Vienne sur le droit des traités. Selon cet article: 'Tout traité en vigueur lie les parties et doit être exécuté par elles de bonne foi.'10

L'article 27 de la même Convention le renforce en ces termes : 'Une partie ne peut invoquer les dispositions de son droit interne comme justifiant la nonexécution d'un traité.'11

Outre ces raisons liées au droit international, l'obligation d'harmonisation de la législation nationale peut également trouver sa justification dans le droit congolais. Aux termes de l'article 215 de la Constitution du 18 février 2006 en vigueur: 'Les traités et accords internationaux régulièrement conclus ont, dès leur publication, une autorité supérieure à celle des lois, sous réserve pour chaque traité ou accord, de son application par l'autre partie.'

Il s'ensuit que pour recevoir application par le juge congolais, en plus d'être conformes à la Constitution, les lois doivent également être en conformité avec les traités internationaux. Or, en dépit de ce double fondement à la fois international et national de l'obligation d'harmonisation de la législation nationale avec les engagements internationaux, la République Démocratique du Congo tarde à exécuter ladite obligation.

Plusieurs raisons sont avancées pour justifier cette situation. Il s'agit, du moins pour le cas du statut de Rome de la Cour Pénale Internationale (qui nous concerne dans le cadre de la présente étude), des lois relatives à la justice militaire et de l'opposition à l'abolition de la peine de mort.

Certes, avec la promulgation des lois portant code pénal militaire ${ }^{12}$ et code judicaire militaire ${ }^{13}$ en RDC, d'aucuns ont estimé qu'il n’était plus nécessaire d'attendre une autre loi de mise en œuvre. Cette opinion est d'autant plus tentatrice que la probabilité de commission des crimes internationaux par les militaires est très élevée. ${ }^{14}$

\footnotetext{
10 Cette convention est disponible en ligne à l'adresse

<http://untreaty.un.org/ilc/texts/instruments/francais/traites/1_1_1969_francais.pdf > dernier accès 3 juin 2012).

11 Ibid.

12 Loi $\mathrm{N}^{\circ} 024 / 2002$.

13 Loi $\mathrm{N}^{\circ} 023 / 2002$.

14 Pendant longtemps l'on a cru que le fait que seul l'ancien code de justice militaire prévoyait les crimes internationaux, ceux-ci relevaient de la compétence exclusive des juridictions militaires. La seule faille de l'ancien code de justice militaire était de ne pas fixer un taux de peine pour les crimes internationaux.
} 
Néanmoins, les principes Decaux ${ }^{15}$ adoptés par les Nations Unies ${ }^{16}$ attestent du contraire. Selon ces principes, bien que commis généralement par des militaires, les crimes internationaux ne sont pas des infractions spécifiquement militaires et il ne faudrait donc pas autoriser les juridictions militaires à les juger. ${ }^{17}$

Ainsi donc, la loi de mise en œuvre du statut de Rome (qui outillerait les juridictions de droit commun dans la répression des crimes internationaux) s'avère indispensable.

La complexité du droit de la Cour Pénale Internationale justifie, à n'en point douter, le besoin pour la République Démocratique du Congo d'édicter des mesures internes ou loi de transposition nécessaires à l'application du statut de Rome. L'on peut citer par exemple le règlement de procédure et des preuves de la Cour Pénale Internationale, établi pour les affaires pendantes devant la Cour et non devant une juridiction nationale; il n'affecte en rien les règles de procédure qu'applique tout tribunal ou système juridique national dans le cadre de poursuites nationales. ${ }^{18}$

A l'instar de tout le droit international, le droit pénal international a besoin d'être traduit, intégré en droit interne pour son application effective. Cette adaptation législative est obligatoire pour les Etats parties au statut; elle est primordiale pour les Etats parties. ${ }^{19}$ En vertu de l'article 88, ils ont la charge de mettre leurs lois nationales en conformité avec les dispositions du statut, en vue de permettre la réalisation de toutes les formes de coopération. ${ }^{20}$ Cette opération a pour but de permettre d'abord à leurs organes judiciaires de pouvoir connaître les crimes prévus par le Statut, et ensuite de faciliter à la Cour une intervention lorsqu'une situation ou une affaire l'exigera. Cette obligation concerne essentiellement la définition des crimes et des peines applicables ainsi que les modalités pratiques de la coopération avec la Cour. Ces dernières impliquent notamment les règles de procédure, la détermination de l'organe nationale compétent pour recevoir les demandes de la Cour, ou encore les conditions du transfert du suspect à la Cour.

Ainsi, par exemple, comme le droit pénal de la République Démocratique du Congo ne définit pas aujourd'hui les crimes de guerre comme des infractions spécifiques, la plupart des faits relevant de cette définition sont poursuivis sur la base des dispositions de droit commun. Cependant, ces dispositions ne permettent pas

\footnotetext{
15 Du nom du Rapporteur des Nations Unies sur la question de l'administration de la justice par les juridictions militaires.

16 Résolution 3314 des Nations Unies.

17 Nations Unies Droits de l'homme Haut Commissariat, 'Rapport du Projet Mapping concernant les violations les plus graves des droits de l'homme et du droit international humanitaire commises entre mars 1993 et juin 2003 sur le territoire de la République démocratique du Congo' (août 2010) <http://www.ohchr.org/Documents/Countries/ZR/DRC_MAPPING_REPORT_FINAL_FR.pdf $>$ dernier accès le 3 juin 2012.

18 François Margo, Garantir l'effectivité des droits des victimes (Fayard 2008) 25.

19 Désiré Jirsob, Renforcer la Cour Pénale Internationale et les Etats parties (Gallimard 2008) 103.

20 Art 88 du statut de Rome de la CPI.
} 
de prendre en compte la particulière gravité due aux conflits armés prévues par le statut de Rome.

Mais qu'a-t-on fait jusqu'ici en vue de cette harmonisation?

\section{Efforts législatifs en vue de l'adaptation du statut de Rome au droit positif congolais}

Outre les lois gouvernant les juridictions militaires mentionnées ci avant, il convient d'épingler les projets de loi déposés sur le bureau de l'Assemblée Nationale de la RD Congo.

Face a la nécessité d'harmonisation du droit congolais avec le statut de Rome, et répondant a l'insistance des organisations de défense des droits de l'homme, le gouvernement congolais avait déposé en 2005 à l'Assemblée Nationale un projet de loi de mise en œuvre du statut de Rome en vue d'adapter les dispositions du statut de Rome au droit positif congolais. Néanmoins, ce projet ne fut jamais examiné jusqu'à ce que ce parlement issu des accords de paix de Sun City termine son mandat.

C'est pourquoi une nouvelle proposition de loi sera déposée par les députés Mutumbe et Nyabirungu. Cette proposition qui était examinée à l'Assemblée $\mathrm{Na}$ tionale le 4 novembre 2010 en commission préalablement au vote article par article. Mais ce dernier devient de plus en plus hypothétique.

L'on pouvait se féliciter de cette étape finalement franchie par cette proposition de loi et penser qu'elle constitue un pas de plus vers l'effectivité de la lutte contre l'impunité des crimes internationaux commis en République Démocratique du Congo dont beaucoup d'auteurs échappent aux poursuites au regard des limites matérielles et juridiques de la Cour Pénale Internationale. Mais c'est la multiplicité des positions aussi bien des autorités gouvernementales que du parlement sur la peine de mort en République Démocratique du Congo qui rend hypothétique l'avènement de cette loi dans un venir plus ou moins court.

\section{L'abolition de la peine de mort l'un des obstacles majeurs à cette adaptation du statut de Rome}

En RDC, la question de l'abolition de la peine de mort se pose dans un contexte particulier et a pratiquement atteint le statut de sujet tabou. Le pays avait déjà commencé sa marche vers l'abolition de ce châtiment (notamment en décrétant un moratoire sur son exécution) lorsque le cours de l'histoire sera sérieusement bouleversé.

Tout part du 16 janvier 2001 lorsque le chef de l'Etat d'alors, Mzee Laurent Désiré Kabila est assassiné dans des conditions ne pas encore élucidées à ce jour. 
Un procès sera organisé, des personnes seront déclarées coupables et condamnées à mort.

Les efforts en vue de ramener la paix rompue par le fait de nombreuses rebellions déchirant le pays, aboutiront à la signature d'un accord de Paix (ci-après l'accord de Sun City). Entre autres résolutions tendant à favoriser la réconciliation nationale, l'accord de Paix de Sun City décidera d'accorder une amnistie générale pour tous les faits de guerre et infractions politiques. Une loi d'amnistie sera votée. Son application suscitera cependant un débat houleux quant à savoir si l'assassinat d'un chef d'Etat en fonction est une infraction politique ou une infraction de droit commun. L'hypothèse de la famille politique du président Joseph Kabila l'emportera, l'assassinat d'un chef d'Etat en fonction sera considérée comme une infraction de droit commun et donc indigne d'amnistie. ${ }^{21}$

Elle montrera clairement qu'il n'est pas question de permettre que les assassins de Mzee Laurent Désiré Kabila soient sauvés de la potence.

C'est dans ce climat que le gouvernement de la RDC dépose sur le bureau de l'Assemblée Nationale une loi portant mise en œuvre du statut de Rome. ${ }^{22}$

Cette loi ne sera jamais examinée. Une rumeur persistante et concordante a rapporté alors qu'il fallait à tout prix éviter de donner une bouée de sauvetage aux assassins de Laurent Désiré Kabila. Or justement ce projet de loi de mise en œuvre coupait court aux tergiversations et abolissait la peine de mort. Pareille loi, si elle était votée, sauverait les assassins de Laurent Désiré Kabila car l'on ne pourra plus leur appliquer une peine abolie.

En 2006, à l'issue des élections générales, Joseph Kabila est élu Président de la République et sa famille politique réussi à obtenir la majorité des sièges au Parlement. L'eau coule sous les ponts, les alliances se font et se défont. Puis ressurgit la question du statut de Rome.

\footnotetext{
${ }^{21}$ Dans son communique de presse numéro N005/RDC/VSV/CD/2010, l'ONG la Voix des sans voix (dont le Président Floribert Chebeya a été assassiné récemment à Kinshasa) fustigeait une politisation de la question de l'amnistie des condamnés a mort.

Elle rappelait que conformément aux prescrits de l'Accord Global et Inclusif et à la Constitution de la transition, l'Assemblée Nationale de la RD Congo avait adopté, le 29 novembre 2005, la loi portant amnistie pour faits de guerre, infractions politiques et d'opinion, et ce, après deux ans de controverse, mieux de blocage unilatéral par de partisans du président Joseph Kabila regroupés dans le Parti du Peuple pour la Reconstruction et la Démocratie (PPRD).

Cette loi avait été adoptée sans la participation des députés issus de la composante dite exgouvernement de Joseph Kabila à cause de leur volonté d'exclure, à tout prix, de la loi d'amnistie les personnes poursuivies et/ou condamnées dans l'assassinat du chef de l'Etat Laurent-Désiré Kabila. Adoptée à la majorité écrasante des députés présents et votants, la loi avait été déposée sur la table du chef de l'Etat pour promulgation endéans quinze jours.

Le chef de l'Etat avait sollicité l'avis de la Cour Suprême de Justice (CSJ) sous forme de question fermée 'Est-ce que l'assassinat d'un chef de l'Etat est une infraction politique ou un crime de droit commun?'. Dans son avis consultatif du 13 décembre 2005, la CSJ considère l'assassinat d'un chef de l'Etat comme une infraction de droit commun, tous les prévenus dans cet assassinat avaient été pourtant, auparavant, condamnés pour des infractions politiques.

22 Nous sommes en 2005.
} 
Un député National ${ }^{23}$ franchit le Rubicon et dépose un projet de loi sur l'abolition de la peine de mort. Mais à l'Assemblée Nationale, ce projet est balayé d'un revers de main.

A la raison évoquée ci-dessus ${ }^{24}$ s'ajoute celle de l'origine même du projet de loi. Le député national André Mbata Mangu Betukumessu est un élu du Rassemblement Congolais pour la Démocratie. Ce parti, basé dans le Kivu est visé par beaucoup d'allégation de massacres dans l'est de la RDC. Il s'est créé un caucus originaires de l'Est de la RDC qui a décidé de barrer la route a ce projet de loi au motif que ceux qui ont semé la mort ne pouvaient pas réclamer l'abolition de la peine de mort avant que n’intervienne un quelconque procès. Dans les couloirs du parlement l'abolition de la peine de mort est également taxée d'être de nature à favoriser l'insécurité, alors qu'avec la peine de mort aujourd'hui, l'insécurité persiste dans notre pays; tandis que des pays sortis de la guerre comme le Rwanda, le Burundi, l'Angola, l'Afrique du Sud, où l'abolition de la peine de mort n'a nullement augmenté la criminalité.

Pendant les débats sur la proposition de loi abolissant la peine de mort, un autre député national ${ }^{25}$ fera une révélation apparemment anodine mais qui sera déterminante pour le processus d'adoption de la loi de mise en œuvre du statut de Rome.

Il rappellera à l'Assemblée Nationale que lui-même était coauteur d'un projet de loi de mise en œuvre du statut de Rome de la CPI et que l'examen de sa proposition serait l'occasion de débattre de la question de la peine de mort. ${ }^{26}$ Depuis, l'on a plus entendu parler de l'examen de ce projet de loi. L'assemblée nationale a par contre examiné plus d'un projet important certes mais pas aussi cruciaux que celui portant mise en œuvre du statut de Rome.

Il ressort des indiscrétions des couloirs de l'Assemblée Nationale que la question de la peine de mort constituait le talon d'Achille de la proposition de loi de mise en œuvre du statut de Rome. Les mêmes causes produisant les mêmes effets, l'Assemblée Nationale semble de justesse éluder le débat sur la peine de mort qu'implique l'examen du projet de loi de mise en œuvre de la CPI.

\section{Perspectives d'avenir pour atteindre le résultat}

En conclusion, si la RD Congo a engagé des poursuites à l'encontre des présumés auteurs des crimes internationaux commis sur son sol; le législateur congolais doit doter notre justice des textes pouvant lui permettre d'accomplir sa mission. C'est

\footnotetext{
23 L'honorable André Mbata Mangu Betukumessu pour ne pas le citer.

24 Il s'agit de la nécessité de la famille politique du Président Kabila de ne pas laisser les assassins du Président Kabila s'échapper de la potence, avons-nous mentionné.

25 L'honorable Nyabirungu Mwene Songa pour ne pas le citer.

${ }^{26}$ En effet, comme le Statut de Rome ne prévoyant pas la peine de mort Mutumbe/Nyabirungu ne l'a pas reprise parmi les peines applicables. C'est ainsi que, profitant de ce débats, le Député Mbata soumettra, le 25 novembre 2010, la proposition de la loi portant abolition de la peine de mort.
} 
ainsi que le plus grand regret est le fait que cette loi de mise en œuvre ne soit examinée et promulguée, renvoyant ainsi une attitude de la République Démocratique du Congo extrêmement ambigüe face à la lutte contre ces atrocités commises sur son sol et qui heurtent la conscience de l'humanité tout entière. ${ }^{27}$

A la fin de cette étude consacrée à l'abolition de la peine de mort comme obstacle majeur au processus de l'adoption de la loi de mise en œuvre du statut de Rome en RD Congo, il importe de relever que la RD Congo, à l'instar des autres Etats, est un des acteurs principaux du développement du droit pénal international qui s'appuient sur des gardes fous, prévus lors de l'adoption du Statut de Rome, pour s'accrocher encore à sa souveraineté. C'est ainsi qu'après avoir créé la CPI et permit son entrée en vigueur, certains Etats hésitent d'être aux cotés de cette institution internationale dans la mise en œuvre de ses dispositions.

La RD Congo qui n'a plus prouver son engagement à voir la Cour Pénale Internationale aller jusqu'au bout des objectifs qui lui sont assignés, doit faire montre d'une volonté ferme de mettre et de maintenir une pression sensible sur les coupables des crimes relevant de cette juridiction; pour cela, elle doit pourvoir à l'harmonisation de son droit pénal interne avec le statut de Rome.

Ce frein de la question de la peine de mort à l'adoption de la loi de mise en œuvre du statut de Rome en RDC inspire plusieurs enseignements. Sur le plan international, la situation en RD Congo révèle les faiblesses du statut de Rome. L'article 80 (qui nous le rappelons a certes eu pour mérite d'offrir un compromis entre abolitionnistes et rétentionistes) ${ }^{28}$ porte les germes d'une confusion qui peut créer des problèmes plus graves que celui qu'il a vocation à résoudre.

Ainsi par exemple, il ressuscite la question de la peine la plus favorable aux personnes accusées. Ce principe fut édicté par le pacte relatif aux droits civils et politiques et veut que les accusés bénéficient d'une nouvelle législation réduisant le taux de la peine impartie pour des faits infractionnels consécutivement après leur commission. Ce principe se rapporte plus au conflit des lois dans le temps. Mais, l'article 80 semble soulever la question de la peine la plus favorable dans le cadre (non certes d'un conflit de loi dans l'espace) mais d'un rapport de loi dans l'espace.

Cette confusion ressort dans le jugement rendu par le Tribunal Militaire de Mbandaka dans l'affaire des crimes internationaux commis à Songo Mboyo. Ce jugement est certes humaniste, mais ne rencontre pas la volonté des pères fondateurs de la Cour Pénale Internationale qui ont voulu donner un chèque en blanc aux rétentionistes en incorporant la disposition de l'article $80 .{ }^{29}$

Il est donc impérieux d'apporter l'article 80 a la conférence de révision. Cet article devrait disparaitre pour éviter toute équivoque dans la gestion du principe de

\footnotetext{
${ }^{27}$ Jeffrey Checkel, 'International Norms and Domestic Politic' (1997) 3 European Journal of International Relations 473

${ }^{28}$ Compromis sans lequel, probablement, le statut de Rome ne serait pas entré en vigueur si tôt.

${ }^{29}$ Et ce contrairement à Robert Badinter selon qui l'idée des pères fondateurs de la Cour Pénale Internationale ne cadre pas avec l'application de la peine de mort. Il serait contradictoire de punir de mort certaines infractions d'une gravite inferieure aux crimes définis par le statut de Rome, lors même que celui-ci n'applique pas cette peine infamante.
} 
complémentarité. La question de peine étant essentielle dans le procès pénal, il n'est pas judicieux de laisser une marge de manœuvre aux juridictions nationales qui laisseraient entrevoir une justice à deux vitesses. Il faudrait donc déjà, pour les acteurs que la question intéresse, entrevoir la mise sur pieds d'un groupe de travail sur la suppression de l'article 80 . Ce groupe de travail préparera l'argumentaire nécessaire pour la prochaine conférence de révision.

Quand à la RD Congo, il est plus que jamais indispensable de lever l'équivoque sur la peine de mort. Il s'agirait soit d'initier un référendum sur la question de la peine de mort (pour ou contre la peine de mort) ou plus simplement de solliciter une interprétation juridictionnelle sur la constitutionalité des dispositions légales établissant la peine de mort.

La Cour Constitutionnelle lorsqu'elle sera mise en place, ou la Cour Suprême de Justice entretemps, devra se prononcer sur cette question étant donné que la constitution de la RDC en décrétant le caractère sacré de la vie humaine semble abolir la peine de mort.

Voila donc, en peu de mots certes mais de manière claire, ce qui cloche dans le processus d'adoption du statut de Rome en RD Congo. Pour peu vérifiables que soient ces affirmations, elles n'en demeurent pas moins plausibles. Après tout, la vie des nations n'est-elle pas jalonnées d'événements importants que personne n'ose porter au grand jour? L'histoire de l'humanité n'est-elle pas faite des événements qui restent occultes parce que les princes n'en donnent pas l'imprimatur?

Tel en est de la question de la peine de mort en RDC et des motivations cachées des retards dans la discussion de la loi de mise en œuvre du statut de Rome. Ce fait social qui plombe an lieu de fonder le droit. 


\title{
Immunity and the implementation legislation in South Africa, Kenya and Uganda
}

\author{
Christopher Gevers
}

\begin{abstract}
This paper considers the relevance of immunity under the Rome Statute implementation legislation adopted by South Africa, Kenya and Uganda, both in terms of cooperation obligations and domestic prosecutions under these instruments. It begins with a discussion of immunity under customary international law, canvassing the historical development of immunity, its differing forms and its current state of development.

In Part 2 the issue of immunity under the Rome Statute, and the conflicting relationship between articles 27 and 98 in particular, will be considered. In this section the two dominant interpretations of this conflict - the article 27 waiver (and its variant the article 27 waiver 2.0) argument and the jurisdiction $v$ state cooperation argument - will be discussed. It will be argued that while the former is the dominant theory amongst scholars the latter has much to recommend it. This section will conclude with a discussion of the somewhat ambivalent position taken by the judges of the International Criminal Court on this debate.

What remains of the paper will consider the issue of immunity under the Rome Statute implementation legislation of South Africa, Kenya and Uganda. First, it will consider whether or not immunity is a basis for non-cooperation by the relevant states insofar as the arrest and surrender of individuals to the ICC under these Acts (Part 3). This question is particularly relevant in light of the decisions by the African Union compelling its member states not to cooperate in the arrest of Sudanese President Omar Al-Bashir. Second, it will consider the applicability of immunity in respect of domestic prosecution of war crimes, genocide and crimes against humanity under these Acts (Part 5). Here it will be suggested that even if certain officials enjoy immunity before South African, Kenyan and Ugandan courts as a matter customary international law, this
\end{abstract}


does not automatically mean such courts will uphold such immunity. Rather, this would ultimately depend on the applicable domestic law: the implementing legislation, and more broadly the role that international law plays in the domestic legal order in question.

The paper concludes that the issue of immunity remains one of the most divisive and debated aspects of the Rome Statute. Given the Court's current clients, and the stated purpose of the ICC to bring those bearing the greatest responsibility for international crimes to justice, this ambiguity could not be more unsettling for the Court and states parties alike. This uncertainty has filtered into the implementing legislation of South Africa, Kenya and Uganda, which themselves have further muddied the water in this regard. Therefore, ICC states parties from Africa should endeavour to ensure clarity within and between their implementation legislation (both current and future) in order to make sure their positions on immunity - which appear to be somewhat at odds with the orthodox position - are given the fullest consideration possible in this process.

\section{Immunité en mise en œuvre de la législation en Afrique du Sud, au Kenya et en Ouganda}

\section{Résumé}

Cet article traite de la pertinence de l'immunité sous la législation d'application du statut de Rome adoptée par l'Afrique du Sud, le Kenya et l'Ouganda, en termes d'engagements de coopération et de poursuites domestiques en vertu de ces instruments. Il commence par discuter de l'immunité en vertu du droit international coutumier, présentant le développement historique de l'immunité, ses formes différentes et son état actuel de développement.

Dans la partie 2 la question de l'immunité sous le statut de Rome, et le rapport contradictoire entre les articles 27 et 98 en particulier, seront étudiés. Dans cette section les deux interprétations dominantes de ce conflit - l'argument de levée de l'article 27 (et sa variante la levée 2.0 article 27) et l'argument de la coopération entre Etat et juridiction - seront discutées. Il est dit que si que la première est la théorie dominante parmi les chercheurs il y aurait beaucoup à gagner de recommander la dernière. Cette section sera conclue avec une discussion sur la position quelque peu ambivalente prise par les juges du tribunal pénal international sur ce débat.

Le reste de l'article étudie la question de l'immunité sous la législation d'application du statut de Rome en Afrique du Sud, au Kenya et en Ouganda. D'abord, il est question de savoir si l'immunité est un motif de non-coopération pour les états concernés en ce qui concerne l'arrestation et la présentation des individus devant le TPI en vertu de ces lois (Partie 3). Cette question est particulièrement opportune à la lumière des décisions par l'union africaine contraignant ses États membres à ne pas coopérer pour l'arrestation du Président soudanais Omar Al-Bashir. En second lieu, il est question de l'applicabilité de l'immunité dans les poursuites domestiques pour 
crimes de guerre, génocides et crimes contre l'bumanité en vertu de ces lois (Partie 5). Ici il est suggéré que même si certains fonctionnaires bénéficient de limmunité devant les tribunaux sudafricains, kényans et ougandais en termes de droit international coutumier, ceci ne signifie pas automatiquement que ces tribunaux confirmeront une telle immunité. Plutôt, cela dépendrait finalement de la loi domestique applicable: la législation de mise en application, et plus largement le rôle que le droit international joue dans le système juridique domestique en question.

L'article conclut que la question de l'immunité demeure l'un des aspects les plus clivants et les plus discutés du statut de Rome. Etant donné les clients actuels de la cour, et le but indiqué du TPI de faire comparaitre ceux qui portent la plus grande responsabilité des crimes internationaux devant la justice, cette ambiguité ne pouvait pas être plus perturbante pour le tribunal et les États parties. Cette incertitude a filtré dans la législation de mise en application de l'Afrique du Sud, du Kenya et de l'Ouganda, qui ont eux-mêmes rendu les choses encore plus confuses. Par conséquent, les états parties africains du TPI devraient essayer d'assurer la clarté à l'intérieur et entre leur législation d'application (actuelle et future) afin de s'assurer que leurs positions sur l'immunité - qui semblent être quelque peu en désaccord avec la position officielle - soient pleinement considérées dans ce processus.

\section{Introduction}

This contribution will consider the issue of immunity under the Rome Statute in light of the Rome Statute implementation legislation adopted by South Africa, Kenya and Uganda. In doing so it will consider the relevance of immunity in relation to both cooperation in arrest and surrender, and domestic prosecutions under these legal instruments. The primary aim here is to catalogue and analyze how South Africa, Kenya and Uganda have chosen to give effect to their obligations both general and specific - under the Rome Statute as they relate to immunities. However, in so doing it will also reveal what these state see as the proper construction of immunity under the Rome Statute - and specifically the relationship between article 27(2) and article 98(1) - by the manner in which they formulate their domestic cooperation regimes. Although it is strictly speaking up to the Court to formulate its construction of the immunity question (something which it has failed to do yet) and the practice of states is not a formal consideration in this process, these provisions might well have some indirect effect on how this relationship is constructed. If only to question the dominant construction of the Rome Statute's immunity provisions by academics, who themselves have relied on state practice in support of their position. In a more direct respect, how African states address the immunity question (both in terms of cooperation and prosecution) will likely influence other states in region incorporate their obligations under the Rome Statute through implementing legislation and other domestic legal measures. 
In order to provide a comprehensive discussion of these issues this contribution will be divided into five parts: Part 1 will discuss the different forms of immunity provided for under customary international law in order to provide its historical background and current state of development; Part 2 will consider the issue of immunity under the Rome Statute, and the conflicting relationship between articles 27 and 98 in particular; Part 3 will then consider the relevance of immunity under the implementing legislation in South Africa, Kenya and Uganda insofar as cooperation in arrest and surrender of individuals to the ICC; Part 4 will consider the relevance of immunity under these acts insofar as domestic prosecution of war crimes, genocide and crimes against humanity ('Rome Statute crimes') are concerned; and Part 5 will make some concluding remarks.

Before doing so it is necessary to note the continuing relevance of the immunity question'. President Al-Bashir of Sudan has been subject to an arrest warrant since March 2009, ${ }^{1}$ becoming the first sitting head of state to be indicted by the ICC. Since then he has visited Kenya and Chad - both of whom are party to the Rome Statute - as well as a number of states that are not. He remains at large, and despite both the Pre-Trial Chamber and the Appeals Chamber having considered the al-Bashir arrest warrant, there remains uncertainty over the question of immunity in relation to proceedings against Al-Bashir and states' cooperation obligations in this regard.

\section{Immunity under International Law}

Immunities have long been considered a legitimate and necessary feature of international law. As Cryer and others note:

The law of immunities as ancient roots in international law, extending back not hundreds, but thousands, of years. In order to maintain channels of communication and thereby prevent and resolve conflicts, societies needed to have confidence that their envoys could have safe passage, particularly in times when emotions and distrust were at their highest. Domestic and international law developed to provide both inviolability for

\footnotetext{
${ }^{1}$ ICC Pre-Trial Chamber I, The Prosecutor v Al Bashir, Warrant of Arrest for Omar Hassan Ahmad Al Bashir (4 March 2009) ICC-02/05-01/09-1. In their original ruling, the judges of the ICC's Pre-Trial Chamber issued an arrest warrant against President al-Bashir for a total of five counts of war crimes and crimes against humanity, but rejected the genocide charges leveled by Prosecutor Luis MorenoOcampo. The Prosecutor appealed this decision, and on 3 February 2010, the Appeals Chamber rendered its judgment, reversing, by unanimous decision, Pre-Trial Chamber I's decision of 4 March 2009, to the extent that Pre-Trial Chamber I decided not to issue a warrant of arrest in respect of the charge of genocide. The Appeals Chamber directed the Pre-Trial Chamber to decide anew whether or not the arrest warrant should be extended to cover the charge of genocide, which it duly did in July 2010. See ICC Pre-Trial Chamber I, The Prosecutor v Al Bashir, Second Warrant of Arrest for Omar Hassan Ahmad Al Bashir (12 July 2010) ICC-02/05-01/09-95.
} 
the person and premises of a foreign State's representatives and immunities from the exercise of jurisdiction over those representatives. ${ }^{2}$

That said, the utility of such immunities has decreased in recent times with the advent of modern communication technologies and professional diplomatic corps. What is more, rise of international criminal law has produced a sometimes competing good: prosecuting those most responsible for international crimes. As a result, there is often an inevitable tension between these two imperatives and, although there is some movement towards resolving this tension in favour of combating impunity, immunities continue to be an absolute (if temporary) bar to prosecution in certain instances.

Immunities can be divided into functional immunity (also known as immunity ratione materiae or subject-matter immunity) and personal immunity (also known as immunity ratione personae or procedural immunity). Immunity ratione materiae relate to conduct carried out on behalf of a State. This form of immunity is based on the notion that 'a State may not sit in judgment on the policies and actions of another State, since they are both sovereign and equal'. ${ }^{3}$ For this reason, functional immunity does not attach to all conduct performed by state officials, rather it only applies to conduct carried out within the official capacity. However, immunity in respect of such conduct is permanent (immunity does not lapse when the official ceases to hold office) and cannot be waived by the state concerned, as it is the conduct itself and not the office bearer that forms the basis of that immunity. This form of immunity is more commonly raised in civil matters. ${ }^{4}$ Immunity ratione personae 'provides complete immunity of the person of certain officeholders while they carry out important representative functions'. ${ }^{5}$ In contrast to functional immunity, personal

2 R Cryer, H Friman, D Robinson, and E Wilmshurst, An Introduction to International Criminal Law and Procedure (1st edn, CUP 2007), 422.

${ }^{3}$ Ibid. The ICTY Appeals Chamber explains the rational for functional immunity as follows:

State officials acting in their official capacity [...] are mere instruments of a State and their official actions can only be attributed to the State. They cannot be the subject of sanctions and penalties for conduct that is not private but undertaken on behalf of a State. In other words, State officials cannot suffer the consequences of wrongful acts which are not attributable to them personally but to the State on whose behalf they act: they enjoy so- called 'functional immunity'.

ICTY Appeals Chamber, Prosecutor v Blaskic, Judgment on the request of the Republic of Croatia for review of the Decision of Trial Chamber II of 18 July 1997 (29 October 1997) IT-95-14-AR108bis, para 38. Akande adds to this, that

the immunity of state officials in foreign courts prevents circumvention of the immunity of the state through proceedings brought against those acting on behalf of the state. In this sense, this immunity operates as a jurisdictional or procedural bar and prevents courts from indirectly exercising control over acts of the foreign state through proceedings against the official who carried out the act.

D Akande, 'International Law Immunities and the International Criminal Court' (2003) 98(3) AJIL 407, 413 .

4 Ibid.

${ }^{5}$ Cryer, in Cryer and others (n 2) 422. Precisely which officials benefit from such immunity is not clear and subject to some debate. Heads of State and Government clearly do, and the ICJ has added 
immunity is absolute (i.e. it covers both private and public acts committed by officials), but temporary (i.e. it only applies insofar as the person holds the office in question) and can be waived by the State concerned.

As far as international criminal law is concerned, there is near universal acceptance of the principle that international crimes cannot be covered by immunity ratione materiae, before international or domestic tribunals, albeit for differing reasons. The International Military Tribunal at Nuremberg - established after World War II to punish Nazi crimes - held that such immunity does not apply to 'acts condemned as criminal by international law'. ${ }^{6}$ Similarly, both ad hoc UN Tribunals contained a provision stating that ' $[\mathrm{t}]$ he official position of any accused person, whether as Head of State or Government or as a responsible Government official, shall not relieve such person of criminal responsibility nor mitigate punishment'. ${ }^{7}$

The same is true in much of domestic jurisprudence on immunity ratione materiae. The most famous decision on the irrelevance of functional immunity being the Pinochet case where, albeit for different reasons, the UK House of Lords found that General Pinochet could not rely on functional immunity in order to avoid being extradited for allegations of torture. ${ }^{8}$ The best explanation of the inapplicability of such immunity in respects of international crimes was that given Lord's BrowneWilkinson and Hutton, to the effect that 'functional immunity does not protect certain international crimes because international law does not protect the same acts that it prohibits and condemns. ${ }^{9}$

The relevance of immunity ratione personae in the prosecution of international crimes is more complex. Here one must separate proceedings before international tribunals and those before domestic courts.

Support for the proposition that customary international law immunity rationae personae does not apply to individuals in proceedings before international courts can be found in the jurisprudence of a number of such courts, as well as academic writings. Since the failed prosecution of Kaiser Wilhelm II under the 1919 Treaty of Versailles, international courts and tribunals have either expressly or by implica-

to this Foreign Ministers, however the Court's finding that 'diplomatic and consular agents, [and] certain holders of high ranking office in a State, such as the Head of State, Head of Government and Minister for Foreign Affairs' enjoy immunity ratione personae suggests that more officials might be added to this list. ICJ, Democratic Republic of the Congo v Belgium Case Concerning the Arrest Warrant of 11 April 2000 (14 February 2002), 51.

${ }^{6}$ In re Goering and others (1946) 13 ILR 203, 221. See further Arrest Warrant case (n 5) 36 (Dissenting Opinion of Judge Van den Wyngaert).

7 Art 7(2) of the ICTY Statute (Statute of the International Criminal Tribunal for the former Yugoslavia) of the ICTR Statute (Statute of the International Criminal Tribunal for Rwanda).

${ }^{8} \mathrm{R} v$ Bow Street Metropolitan Stipendiary Magistrate and others ex parte Pinochet Ugarte (No. 3) [1999] 2 All ER 97, HL.

${ }^{9}$ Friman, in Cryer and others (n 2) 430. See further C Chinkin, 'Regina v Bow Street Stipendiary Magistrate, Ex Parte Pinochet Ugarte (No. 3)' (2003) 93 AJIL 703. See however D Akande 'International Law Immunities' (n 3 ) 414-415. 
tion considered such immunities to be irrelevant for their purposes. ${ }^{10}$ The Statute of the post-World War II Nuremburg Tribunal stated: 'Leaders, organizers, instigators and accomplices participating in the formulation or execution of a common plan or conspiracy to commit any of the foregoing crimes are responsible for all acts performed by any persons in execution of such plan'. ${ }^{11}$ Although the ad hoc UN Tribunals of the 1990's did not contain a specific provision addressing immunity ratione personae, the ICTY indicted Slobodan Milosevic while he was a still a sitting head of state. Similarly, the bybrid Special Court for Sierra Leone similarly (but not without controversy) held that 'the principle seems now established that the sovereign equality of states does not prevent a Head of State from being prosecuted before an international criminal tribunal or court'. ${ }^{12}$ Finally, in the Arrest Warrant case the ICJ stated that:

[A]n incumbent or former Minister for Foreign Affairs may be subject to criminal proceedings before certain international criminal courts, where they have jurisdiction. Examples include the International Criminal Tribunal for the former Yugoslavia, and the International Criminal Tribunal for Rwanda, established pursuant to Security Council resolutions under Chapter VII of the United Nations Charter, and the future International Criminal Court created by the 1998 Rome Convention. ${ }^{13}$

Once again the reason for such immunities being removed before international courts and tribunals is not subject to the same unanimity. For some, this removal is automatic (and axiomatic) given the supranational nature of these courts; which precludes the rationale for granting such immunity in the first place from applying to them. Others take a more cautious (and correct) view, noting that the question of whether such immunities are removed depends on the provisions of the court in questions founding instrument, and the manner in which it was established. ${ }^{14}$ In this regard the ICC is different from all previous international tribunals in that it was established by a universal, multilateral treaty (i.e. the consent of states) and not

10 Art 227 of the Treaty of Versailles states:

The Allied and Associated Powers publicly arraign William II of Hohenzollern, formerly German Emperor, for a supreme offence against international morality and the sanctity of treaties. A special tribunal will be constituted to try the accused, thereby assuring him the guarantees essential to the right of defence. It will be composed of five judges, one appointed by each of the following Powers: namely, the United States of America, Great Britain, France, Italy and Japan $[\ldots]$.

${ }^{11}$ Art 6, Charter of the International Military Tribunal (1946).

12 SCSL Appeals Chamber, Prosecutor $v$ Charles Taylor, Decision on Immunity from Jurisdiction, (May 31, 2004) SCSL-03-01-I-059, 52.

13 Arrest Warrant Case (n 5) 61.

14 Akande (n 3) 417 notes: 'Whether or not those wanted for prosecution by an international criminal tribunal may rely on international law immunities to exempt themselves from its jurisdiction depends, firstly, on the provisions of the statute establishing that tribunal [...] [and secondly] on the nature of the tribunal: how it was established and whether the state of the official sought to be tried is bound by the instrument establishing the tribunal.' 
by a Security Council Resolution (ICTY, ICTR) or by a Special Agreement between a state and the $\mathrm{UN}$, or an agreement amongst the victorious powers or a peace treaty. ${ }^{15}$ As we shall see below, this question has important consequences for the question of whether the irrelevance of immunity before international courts extends to the cooperation of states in arresting and surrendering individuals to such courts.

Conversely, there is considerable authority for the opposite proposition insofar as domestic courts are concerned, namely that immunity ratione personae continues to apply in such proceedings. ${ }^{16}$ In this regard it was noted that 'while inroads have been made into functional immunity, State practice and jurisprudence have consistently upheld personal immunity, regardless of the nature of the charges?. ${ }^{17}$ Most clearly (and authoritatively), in the Arrest Warrant case the ICJ held that Belgium had 'failed to respect the immunity from criminal jurisdiction and the inviolability which the incumbent Minister for Foreign Affairs of the Democratic Republic of Congo enjoyed under international law' when it issued an arrest warrant for him for crimes against humanity and war crimes. ${ }^{18}$ This has been confirmed by a number of domestic courts in subsequent decisions in the UK (in respect of General Pinochet, ${ }^{19}$ albeit obiter), Belgium, France, Spain and the United States, amongst others. ${ }^{20}$

\footnotetext{
${ }^{15}$ For this reason, Akande (ibid) argues, in respect of the ICC, that since only parties to a treaty are bound by its provisions, a treaty establishing an international tribunal cannot remove immunities that international law grants to officials of states that are not party to the treaty. Those immunities are rights belonging to the nonparty states and those states may not be deprived of their rights by a treaty to which they are not party.

See however P Gaeta, 'Official Capacities and Immunities' in A Cassese, P Gaeta and J Jones (eds), The Rome Statute of the International Criminal Court: A Commentary (OUP 2002) 993-996.

16 Akande (n 3) 411 notes:

Judicial opinion and state practice on this point are unanimous and no case can be found in which it was held that a state official possessing immunity ratione personae is subject to the criminal jurisdiction of a foreign state when it is alleged that he or she has committed an international crime.
}

${ }^{17}$ Friman, in Cryer and others (n 2) 425.

18 Arrest Warrant Case(n 5) 75.

${ }^{19}$ For instance, Lord Nicholls in the first Pinochet case held that ' $[. .$.$] there can be no doubt that if$ Senator Pinochet had still been the head of the Chilean state, he would have been entitled to immunity' (see R v Bow St Magistrate, ex parte Pinochet Ugarte, [1998] 4 All ER (Pinochet 1), 938). Lord Millett in the third Pinochet case said that 'Senator Pinochet is not a serving head of state. If he were, he could not be extradited. It would be an intolerable affront to the Republic of Chile to arrest him or detain him' (see R v Bow St Magistrate, Exp. Pinochet (No.3) [1999] 2 WLR 824, 905 H).

20 See for example: Ghaddafi case, No. 1414 (Cass. crim. 2001) (Fr.), 125 ILR 456; Castro case, No. 1999/2723, Order (Audiencianacional Mar. 4,1999) (Spain); H.S A. and others v S.A., Cass. 2e civ., Feb. 12, 2003, No. P.02.1139.F (Belg.), translated in 42 ILM 596 (2003); Regina v Bow Street Stipendiary Magistrate, ex parte Pinochet (No.3), [1999] 2 All E.R. 97, 126-27, 149,179, 189 (H.L.) (per Goff, Hope, Millett, Phillips, L.JJ.); Plaintiffs A, B, C, D, E, F v Jiang Zemin, 282 F.Supp.2d 875 (N.D. Ill. 2003); Tachiona v Mugabe, 169 F.Supp.2d 259 (S.D.N.Y. 2001); Arrest Warrant Against General Shaul Mofaz (Bow St. Mag. Ct. Feb. 12, 2004) 53 ICLQ769, 771. 
As to the scope of personal immunity, while it clearly applies to Heads of State and according to the ICJ Foreign Minister as well, it remains to be determined which other officials enjoy this form of immunity whilst in office. In the Arrest Warrant case, the ICJ held:

[T] he functions of a Minister for Foreign Affairs are such that, throughout the duration of his or her office, he or she when abroad enjoys full immunity from criminal jurisdiction and inviolability. That immunity and that inviolability protect the individual concerned against any act of authority of another State which would hinder him or her in the performance of his or her duties. ${ }^{21}$

Therefore, under customary international law Heads of State and certain other officials enjoy absolute personal immunity, even for international crimes, before the domestic courts of other states.

In summary, the state of development of international law regarding the application of immunities to international criminal law is as follows: Immunity ratione materiae (or functional immunity) does not apply to such prosecutions, regardless of the forum (i.e. international or domestic). Immunity ratione personae (or personal immunity) arguably does not apply before most (if not all) international courts but continues to apply before domestic court's unless a waiver from the state concerned can be obtained.

This is only half the question: Firstly, the issue of whether immunities apply before the ICC - both in terms of the exercise of jurisdiction by the Court and in terms of the obligation on states to cooperate in arrest and surrender proceedings - must be resolved under the Rome Statute itself. Secondly, even if certain officials enjoy immunity ratione personae before South African, Kenyan and Ugandan courts - either in terms of arrest and transfer proceedings under the Rome Statute or domestic prosecutions under their implementing legislation - this does not automatically mean such will uphold such immunity. Rather, this would ultimately depend on the applicable domestic law: the implementing legislation, and more broadly the role that international law plays in the particular domestic legal order. ${ }^{22}$

The remaining part of this paper will consider these questions by addressing the question immunity under the Rome Statute and the three implementing acts insofar as cooperation is concerned, and thereafter under the domestic regimes established under those acts for prosecuting international crimes.

\footnotetext{
21 Arrest Warrant Case (n 5) 45.

22 This does not mean that the country concerned will be able to rely on that provision to avoid responsibility for the breach of its obligations under international law to respect such immunity.
} 


\section{The Rome Statute and Immunity}

The Rome Statute has prima facie conflicting provisions on immunity. Article 27(1) states:

This Statute shall apply equally to all persons without any distinction based on official capacity. In particular, official capacity as a Head of State or Government, a member of a Government or parliament, an elected representative or a government official shall in no case exempt a person from criminal responsibility under this Statute, nor shall it, in and of itself, constitute a ground for reduction of sentence.

This provision is generally understood as referring to functional immunity, making it clear that it is inapplicable to any individual before the ICC. It is based on article $7(2)$ of the ICTY Statute (and 6(2) of the ICTR Statute). For the purposes of the Rome Statute this is not controversial as it simply restates the now accepted position under international law. ${ }^{23}$ Admittedly this provision is not a model of clarity, and is not limited to functional immunity alone.

The Rome Statute's personal immunity provision proper, is article 27(2) which states:

Immunities or special procedural rules which may attach to the official capacity of a person, whether under national or international law, shall not bar the Court from exercising its jurisdiction over such a person.

This provision makes clear that such immunities do not apply when the Court is exercising jurisdiction over an individual. This itself is not controversial, as noted above in the Arrest Warrant case the ICJ explicitly cited article 27(2) as an exception to the customary international law diplomatic immunity that certain state officials enjoy. ${ }^{24}$ It is novel however, the statute of the ICTY and ICTR do not contain a correlative provision.

The difficulty comes in trying to reconcile article 27(2) with article 98(1), which states:

The Court may not proceed with a request for surrender or assistance which would require the requested State to act inconsistently with its obligations under international law with respect to the State or diplomatic immunity of a person or property of a third State, unless the Court can first obtain the cooperation of that third State for the waiver of the immunity.

\footnotetext{
${ }_{23}$ However, it does impact upon South Africa's Rome Statute Act (2002) (SA Rome Statute Act (2002)).

24 Arrest Warrant Case (n 5) para 61.
} 
A number of approaches have been adopted to reconciling this contradiction, with varying effects on the integrity of the two provisions. ${ }^{25}$

The approach adopted by most academics has been to interpret article 27 as a waiver by a State party of any immunity that might otherwise apply to their officials before the ICC, limiting article 98(1)'s application to the case of officials from a state that is not a party to the Rome Statute. ${ }^{26}$ Proponents of this argument generally argue that as a matter of logic, and the doctrine of effective construction, 'the removal of immunity in Article 27 must be understood as applying not only in relation to the ICC itself, but also in relation to states acting at the request of the ICC'. ${ }^{27}$

The upshot of this interpretation is that the ICC has a bifurcated immunity system: one for officials from states that are a party to the Rome Statute, and one for officials from states who are not parties. For officials from state parties, neither functional nor personal immunity applies with respect to any proceeding connected to the ICC, as the state has waived any rights such officials may have to such immunities through Article 27. For officials from non-state parties, since those states have not ratified the Rome Statute they have not, as a matter of treaty law, waived the applicable immunities enjoyed by their officials and thus article 98(1) preserves their immunity and provides that their arrest and surrender can only be carried out by a state party if 'the Court can first obtain the cooperation of that third State for the waiver of the immunity'.

The same result can be reached by another interpretation that focuses on article 98 rather than article 27. On this interpretation, set out by Gaeta, the reference

25 Prosaically, this apparent contradiction can be explained by the fact that article 27 and article 98 were drafted by different committees in Rome. O Triffterer, 'Article 27' in O Triffterer (ed), Commentary on the Rome Statute of the International Criminal Court: Observers' (OUP 1999).

26 Akande (n 3) 425. B Broomhall, International Justice and the International Criminal Court: Between Sovereignty and the Rule of Law (OUP 2003) 145; W Schabas, Introduction to the International Criminal Court (CUP 2001); Gaeta (n 15) 993-96; S Wirth, 'Immunities, Related Problems and Article 98 of the Rome Statute' (2001) 12 Criminal Law Forum 429, 452-54.

${ }^{27}$ For example, Akande (n 3) 423 - 424 notes:

[A]n interpretation that allows officials of states parties to rely on international law immunities when they are in other states would deprive the Statute of its stated purpose of preventing impunity and ensuring that the most serious crimes of international concern do not go unpunished. Furthermore, the removal of immunity from the exercise of the Court's jurisdiction contained in Article 27 would be nullified in practice if Article 98(1) were interpreted as allowing parties to rely on the same immunities in order to prevent the surrender of their officials to the Court by other states. This argument is supported by the principle that "[a]n interpreter is not free to adopt a reading that would result in reducing whole clauses or paragraphs of a treaty to redundancy or inutility."

Thus, the removal of immunity in Article 27 must be understood as applying not only in relation to the ICC itself, but also in relation to states acting at the request of the ICC. This argument is supported by the fact that, as discussed above, the removal is contained not only in Article 27(2) - which stipulates that immunities are not to bar the ICC from exercising jurisdiction but also in Article 27(1). 
in article 98 to 'third states' should be interpreted to as non-states parties. 28 The result is the same, except that instead of seeing article 27(2) as the waiver by states parties of the obligations on all other states under article 98 to grant diplomatic immunity ratione personae, article 98 is read as only recognizing that obligation in respect of non-states parties. Of the two arguments the former (article 27 waiver argument) is preferable, but neither one is entirely satisfactory.

The problem with the article 27 waiver argument is that its proponents - to varying degrees - fail to take seriously the difference between the Court's exercise of its jurisdiction, and the obligation of cooperation on states. Some see no distinction eliding the two completely - whilst others acknowledge the formal distinction but gloss over it in practice, losing sight of its significance in the process. ${ }^{29}$ All overstate the effect of separating the exercise of jurisdiction from cooperation obligations on the Court's efficacy in combatting impunity for international crimes. The implicit assumption of this construction of the article 27/98 relationship is that the distinction itself is of no value, or not of sufficient value to give these provisions a purpose in and of themselves. As we see below there is support for maintaining this distinction in the Statute, and in fact there is at least one other example of this separation in practice.

As a result, proponents of this argument incorrectly rely on the doctrine of effective construction in supporting of their interpretation of articles 27 and 98. This doctrine - based on the maxim Ut Res Magis V aleat Quam Pereat ${ }^{30}$ - takes on different forms but can best be understood as to require that one 'avoid interpretations which would leave any part of the provision to be interpreted without effect'. ${ }^{31}$ Proponents of the article 27 waiver argument use it as the basis for reading down the effect of article 98(1), as Akande notes:

[R]eading Article 27 as applying only to actions by the Court would render parts of that provision practically meaningless [...] because the Court has no independent powers of arrest. A proclamation that immunities shall not bar the exercise of jurisdiction by the Court while leaving such immunities intact with respect to arrests by national authorities would mean that the

\footnotetext{
${ }^{28}$ See also P Gaeta 'Official Capacities and Immunities' (n 15) 993-4.

${ }^{29}$ See Akande 'International Law Immunities' (n 3) 420.

30 Translation: 'That the thing may rather have effect than be destroyed'.

31 P. St. J Langan, Maxwell on Statutory Interpretation (12th edn, Sweet \& Maxwell, 1969), 45. The doctrine has been employed by the ICJ and the Appeals Chamber of the ICTY. See ICTY Appeals Chamber, Prosecutor v Krstic, Judgement (19 April 2004) IT-98-33-A, para. 139. See L Oppenheim and others, Oppenheim's International Law (9th edn, Longman 2000), 1280. See also the ICJ, Chorzow Factory Case (1927) PCIJ Series A, Volume 2, No. 8, at 2 and the ICJ, Corfu Channel Case, (1949) ICJ Reports 4.
} 
Court would hardly be in a position to apply Article 27 and exercise its jurisdiction. $[\ldots] \cdot 32$

The problem with relying on this doctrine is two-fold: First, it misconstrues in favour of an interpretation that increases (or does not decrease) the Statute's effectiveness in achieving its purpose, and not one that makes the provisions themselves effective. By employing the doctrine of effective construction in this manner, proponents of this approach conflate this doctrine - which is designed to make sure that each provision has a purpose - with the teleological or purposive approach which favours an interpretation which achieves the purpose of the particular treaty. ${ }^{33}$ Second, if proper consideration is given to the distinction between the exercise of jurisdiction by the Court, and the obligations on states parties to cooperate, there can be no argument that they must be read together in order for each to have an 'effect', their function lies in regulating aspects of the Rome Statute which are related in practice, but conceptually distinct.

What is more, the proper application of the doctrine might well result in the opposite result, as the article 27 waiver argument leaves article 98(1) considerable less effective. This is particularly true if one considers the article 27 waiver $2.0^{34}$ argument as applied to states referred to the Court by the Security Council, to which we will now turn.

The article 27 waiver - which created a two-tier immunity system for states parties and non-states parties - was shaken by events on the ground: namely the arrest warrant issued for President Al-Bashir in March 2009. The problem being that the strict application of the argument would mean that Al-Bashir - as the head of state of a non-party state (or a 'third state') - would benefit from article 98(1). For this reason the article 27 waiver argument was extended to states such as Sudan by arguing that referrals by the Security Council effectively place their subjectstates in the same position of state parties insofar as immunities are concerned. ${ }^{35}$ In terms of this argument the Security Council's decision to confer jurisdiction on

32 D Akande, 'The Legal Nature of Security Council Referrals to the ICC and its Impact on Al Bashir's Immunities' (2009) 7(2) Journal of International Criminal Justice (JICJ) 333, 338 notes further:

To read the treaty in this way would be contrary to the principle of effectiveness in treaty interpretation. According to this principle, a treaty interpreter must read all applicable provisions of a treaty in a way which gives meaning to all of them harmoniously and "is not free to adopt a reading that would result in reducing whole clauses or paragraphs of a treaty to redundancy or inutility".

33 That is not to say that its proponents cannot make a teleological argument in favour of their interpretation, but this would be much less persuasive then one based on the terms of the Statute itself. Notably, Akande (n 3) 423 acknowledges that 'the fact that a denial of immunity may be desirable to make the ICC more efficacious is not a sufficient reason to imply such a waiver of immunity'.

34 With apologies.

35 See generally Akande (n 34). Note, not every proponent of the article 27 waiver argument supports its extension to Security Council referrals. See P Gaeta, 'Does President Al Bashir Enjoy Immunity from Arrest?' (2009) 7(2) JICJ, 315-332. 
the ICC in terms of the Rome Statute is considered to include every provision of the Statute that defines how the exercise of such jurisdiction is to take place, including article 27(2). ${ }^{36}$ The only difference being that the source of that country's obligations to accept the provisions of the Statute are derived from article 25 of the UN Charter. On this view, the immunities of the President al Bashir (and more recently the late Colonel Gadhafi) are removed by article 27 thus states parties are not required to seek a waiver of Al-Bashir's head of state immunity from Sudan before arresting him and surrendering him to the ICC under article 98.

As will be discussed below, the contention that this argument conflates the exercise of jurisdiction by states and obligations of cooperation on states is even more convincing insofar as Security Council referrals are concerned. This is because the two legal concepts are by no means coextensive in such circumstances: Security Council Resolutions 1593 and 1970 implicitly recognizes this. Even though the Security Council is empowered to compel states to cooperate with the Court $^{37}$, it chose not to impose cooperation obligations on states other that Sudan and Libya respectively, rather is merely urged them to do so.

The main problem with this addition to the waiver argument is that, on its proponent's construction of the article 27/98 relationship, it in effect renders article 98 'practically meaningless'. The only other way that a matter can come into the Court's jurisdiction is through an ad hoc self-referral by a non-states party under article 12 of the Rome Statute. However, in such circumstances that state is bound to 'cooperate with the Court without any delay or exception in accordance with Part 9'. 38 The effect of article 98 would be limited to circumstances where an official of a non-state party is sought by the Court for crimes committed on the territory of a state party - jurisdiction thus flowing from ordinary base of jurisdiction (territoriality). This is not impossible, Jean-Pierre Bemba is currently being tried by the ICC for crimes allegedly committed in the Central African Republic, although he is a national of the DRC. He was one of four Vice-Presidents in the DRC's transitional government, although he was not in office (and therefore not the beneficiary of immunity) when the Court issued a warrant for his arrest in 2008. Charles Taylor, the former President of Liberia, is standing trial for his part in the Sierra Leone war. However, this leaves very little for article 98(1) to do.

It is worth noting that proponents of both versions of the waiver argument cite state practice in support of this construction, as Akande notes:

\footnotetext{
36 The argument is convincing insofar as cooperation from the referred state (Sudan and Libya) is concerned. Notably, the same result can be reached by considering the terms of United Nations Security Council (UNSC) Resolutions 1593 and 1970 for Sudan and Libya to cooperate fully with the Court: UNSC Res 1593(2005), 31 March 2005, S/RES/1593(2005), and UNSC Res 1970(2011), 26 February 2011, S/RES/1970(2011).

${ }^{37}$ See article 25 of the UN Charter (United Nations, Charter of the United Nations, 1 UNTSXVI, 26 June 1945, entered into force 24 October 1945), and UNSC Res 827(1993), 25 May 1993 , $\mathrm{S} / \mathrm{RES} / 827(2003)$.

38 Rome Statute, art 12(3).
} 
The view that Article 98(1) applies only to officials of nonparties has been taken by scholars and by some ICC parties. This view is reflected in the legislation of a number of ICC parties implementing their obligations under the ICC Statute. ${ }^{39}$

Although it is not suggested that such practice amounts to a subsequent agreement between states parties as to the interpretation of these provisions - pursuant to article 31(3)(b) of the Vienna Convention on the Law of Treaties (1969) - it is offered as persuasive nonetheless..$^{40}$

The alternate approach to the article 27 /article 98 relationship is to maintain a strict separation between 'the power of an international court to exercise its jurisdiction over an individual' and 'the powers and obligations of states when requested to carry out coercive acts against individuals protected by personal immunities', ${ }^{41}$ and argue that article 27 of the Rome Statute refers only to the former, and article 98 the latter.

In this regard Gaeta correctly notes:

[T] he "inapplicability" of the rules of customary international law on personal immunities before international criminal courts does not per se imply the "inapplicability" of said rules when it comes to the arrest and surrender to an international criminal court by the competent national authorities of a given state. ${ }^{42}$

Despite being a minority position amongst academics, this interpretation has much to recommend it. Textually, article 27(2) is open to narrow interpretation that focuses on the Court's exercise of jurisdiction and not the cooperate regime which involves the rights and obligations of states. Consider the different wording chosen in article 27(1) - which refers to the Statute - compared to article 27(2) which refers to the Court's jurisdiction. As far as article 98(1) is concerned it must be noted that it applies to 'requests for surrender or assistance' therefore its scope is wider than, and therefore not coextensive with, that of article 27. Contextually, articles 27 and 98 are from different sections of the Rome Statute. Although some provisions relating to states obligations appear in other parts of the statute, they should be limited to Part 9. First, Part 9 is headed 'International Cooperation and Judicial Assistance'. Second, article 88 states 'States Parties shall ensure that there are procedures available under their national law for all of the forms of cooperation which are speci-

\footnotetext{
39 Akande (n 3) 422 goes on to list section 23(1) of the UK's International Criminal Court Act of 2001, as well as the 'identical provisions and language are used in the relevant legislation of Malta and Ireland'. See Further, he notes that the implementation legislation of Canada and New Zealand 'goes even further and appears to provide that no person may rely on international law immunities in proceedings instituted pursuant to an ICC request for arrest and surrender.'

40 See Akande (n 3) 425-426.

${ }^{41}$ Gaeta (n 35) 325.

42 Ibid.
} 
fied under this Part'. No such provision exists in respect of the rest of the Rome Statute.

What is more, while the issue of requests for surrender and the exercise of jurisdiction are easy to conflate, as they seem to be part of one and the same process, jurisdictional provisions are conceptually separate from cooperation provisions. Returning to first principles, article 27 confirms that the existence of immunity ratione personae is neither a bar to the Court's prescriptive jurisdiction (loosely article 27(1)), nor to its enforcement jurisdiction (article 27(2)). ${ }^{43}$ Whilst article 98 makes states obligation to exercise, inter alia, their enforcement jurisdiction in respect of foreign official enjoying immunity conditional on the waiver of such immunity by that 'third state'.

The separation of the exercise of jurisdiction by the Court, and the creation (and qualification) of cooperation obligations, is recognized in other parts of the Rome Statute and has been upheld by the Court itself in the form of arrest warrant proceedings. Although the provisions relating to arrest warrants are clumsily formulated, on the interpretation given to them by the Court the mere issuance of an arrest warrant under article 58 does not trigger obligations to arrest. Rather, it must be subject to an additional request for cooperation issued by the registry under article 89. In this regard Sluiter notes:

Strictly speaking, one should distinguish the arrest warrant from the request for arrest and surrender. The former is not susceptible to review at the national level, whereas the latter is subject to the requirements of Article $91(2)(\mathrm{c})$, and must be supported by sufficient evidence. An interim release on account of insufficient evidence is, therefore, not based on the ultra vires character of the warrant, but on an alleged court violation of Article $91(2)(\mathbf{c}) \cdot{ }^{44}$

Therefore, like article 27, an arrest warrant under article 58 that is conditional on an additional provisions contained in part 9 to create an obligation of arrest on states seems illogical is the two are seen as one and the same. But it makes sense if

${ }^{43}$ R O'Keefe, 'Universal Jurisdiction: Clarifying the basic concept' (2004) 2 JICJ 736, 737 notes:

Jurisdiction is not a unitary concept. On the contrary, both the long-standing practice of states and doctrinal writings make it clear that jurisdiction must be considered in its two distinct aspects, viz. jurisdiction to prescribe and jurisdiction to enforce. Jurisdiction to prescribe or prescriptive jurisdiction $[. .$.$] refers, in the criminal context, to a state's authority under international law$ to assert the applicability of its criminal law to given conduct, whether by primary or subordinate legislation, executive decree or, in certain circumstances, judicial ruling. Jurisdiction to enforce or enforcement jurisdiction [...] refers to a state's authority under international law actually to apply its criminal law, through police and other executive action, and through the courts. More simply, jurisdiction to prescribe refers to a state's authority to criminalize given conduct, jurisdiction to enforce the authority, inter alia, to arrest and detain, to prosecute, try and sentence, and to punish persons for the commission of acts so criminalized.

${ }^{44}$ G Sluiter, 'The Surrender of War Criminals to the International Criminal Court' (2003) 25 Loyola of Los Angeles International and Comparative Law Review 624, 625. 
one considers article 58 as the Court's exercise of its enforcement jurisdiction to subjecting a person to arrest, and then article 89 as relating to the obligations on states to give cooperate in enforcing that warrant.

Proponents of the article 27 waiver argument would most likely contend that this is a conservative, overly-technical (or worse still sophist) interpretation of the Rome Statute, and in particular the relationship between the Court's jurisdiction and states cooperation obligations. However, one might counter that this strict separation is not only clear but necessary (and progressive) in some respects.

As noted above, although the two often happen at the same time- most times but not always - they are not coextensive. There are at least two (possibly three) practical examples of when the Court's jurisdiction must be separate from, or more than, the obligations of states to give effect to it.

The first is the Security Council referral, where the Court's ability is exercise jurisdiction is extended beyond the scope of the obligations on states parties to cooperate under the Rome Statute. Not only is this separation necessary to allow the Court to exercise jurisdiction over Security Council referrals, viewing these two as coextensive would render the ICC far less effective insofar as cooperation insofar these referrals are concerned. This is because the Security Council has the power to make all states cooperate with an investigation and prosecution initiated under article 13(b) by virtue of Article 25 of the UN Charter, thereby expanding the cooperation obligations regime beyond states parties to the Rome Statute. ${ }^{45}$ Although the Council has refrained from doing so in respect of the Darfur and Libyan referrals, ${ }^{46}$ it has done so in respect of the ad hoc Tribunals and there is no obvious reason why it cannot do the same in respect of the ICC. ${ }^{47}$ However, in such instances,

45 In this regard, Sluiter sets out three possible models of cooperation available to the Council insofar as international judicial mechanisms are concerned:

First, the Council could simply refer a situation without any reference to cooperation; this would mean that the 'normal' regime of the Statute applies and that only obligations for states parties can be established. In case the Council opts for the imposition of obligations for states nonparties there would be the choice, as to the substance of the duties, to apply the ICC Statute mutatis mutandis, or to develop a separate, possibly more demanding regime.

46 The Council clearly intended that only the referred states themselves were under an obligation under Chapter VII to 'cooperate fully', the resolution merely urges all States and concerned regional and other international organizations to cooperate fully. See UNSC Res 1593(2005) and UNSC Res 1970(2011) (n 36). The use of urges with regard to the latter in contrast to decides and shall with regard to the former is significant. This is because the importance of language in determining the Council's intention cannot be overstated. ICJ, Legal Consequences for States of the Continued Presence of South Africa in Namibia (South West Africa) notwithstanding Security Council Resolution 276 (1970), Advisory Opinion, I.C.J. Reports 1971, para 114.

47 UNSC Res 827(1993) (n 37) para 4 - which established the ICTY - states that

$[\ldots]$ all States shall cooperate fully with the International Tribunal and its organs in accordance with the present resolution and the Statute of the International Tribunal and that consequently all States shall take any measures necessary under their domestic law to implement the provisions of the present resolution and the Statute, including the obligation of States to comply with requests for assistance or orders issued by a Trial Chamber under Article 29 of the Statute. 
if the Court's jurisdiction and cooperation regime were coextensive (and therefore mutually limiting) the Court would not be able to benefit from the expanded cooperation regime provided for by the Council.

The second is in circumstances of voluntary surrender. ${ }^{48}$ While initially considered unlikely, nine individuals have voluntarily appeared before the Court already. The first person to voluntarily appear before the Court under this procedure was Bahr Idriss Abu Garda, who appeared in May 2009 on the basis of a summonses issued by Pre-Trial Chamber I on 7 May 2009 relating to an attack on peacekeepers in Sudan. During the initial hearing the Prosecutor indicated that he would not seeking an arrest warrant as Abu Garda had indicated his willingness to appear voluntarily. He was followed by Abdallah Banda Abakaer Nourain and Saleh Mohammed Jerbo Jamus who voluntarily appeared in June 2010 pursuant to a summons issued in August 2009 in connection with the same attack. On 8 February, 2010, Pre-Trial Chamber I refused to confirm the charges against Abu Garda, whilst the charges against Banda and Jerbo were confirmed unanimously by PreTrial Chamber I on 7 March 2011. In April 2011, six Kenyans appeared before Pre-Trial Chamber II following a summonses issued in respect of their roles in the 2008 post-electoral violence.

The third possible situation where the Court will exercise jurisdiction in situations where no cooperation obligations on states are involved is surrender by a non-state actor. Although there is no provision for it in the Rome Statute, there is precedent for regional or international peace enforcement operations arresting and surrendering accused person to international courts. ${ }^{49}$

In all three of these instances Part 9 of the Rome Statute (which contains states cooperation obligations) in no way conditions the Court's exercise of jurisdiction, as the two are conceptually separate. If this were not the case, then the Court would not be able to exercise jurisdiction over such individuals. If this is the case, then by parity of reasoning the exercise of article 27 should not condition the application of article 98 . Considered in this light, it is difficult to accept the article 27 waiver proponents contention that article 98(1) must be read down in order to give article 27(2) purpose, as it functions in at least two if not three instances where article 98 is not even in play.

This phrase was repeated verbatim in UNSC Res 955(1994), 8 November 1994, S/RES/955(1994) establishing the ICTR.

48 An alternate, less coercive, means that an arrest warrant available to the Prosecutor to secure the attendance of the suspect before the Court is to request the Pre-Trial Chamber to issue a summons for his or her appearance under article 58(7). Such a request will only be granted if the Pre-Trial Chamber is satisfied that 'there are reasonable grounds to believe that the person committed the crime', and that the summons alone will be sufficient to secure the accused's attendance.

${ }^{49}$ Both KFOR and UNMIK arrested ICTY suspects and transferred them to The Hague under Security Council Resolution 1244 which (at para 14) '[demanded] full cooperation by all concerned, including the international security presence, with the International Tribunal for the Former Yugoslavia'. See ICTY Appeals Chamber, Prosecutor v Nikolic, Interlocutory Appeals Decision (5 June 2003) IT-94-2-AR73. See further Akande (n 3) fn 116. 
One final issue worth mentioning before looking at how the Court has considered this question is that of who decides when the conditions in article 98 are met. The language of that article is not clear on this, stating that 'the Court may not proceed' unless it can obtain a waiver from a state where such is necessary to prevent 'the requested State to act inconsistently with its obligations under international law', but it does not explicitly give the Court the power to determine when this is the case. An argument could be made that it is the responsibility of states themselves to determine the applicability of their international obligations to other states. Notably, article 97 requires a state party that receives a request from the Court in relation to which it identifies problems which may impede or prevent the execution of the request [...] shall consult with the Court without delay in order to resolve the matter.' This too is vague on who decides and whether, if it is the Court, states are bound by such a determination. Rule 195(1) of the Court's Rules of Procedure and Evidence suggests that it is the Court that decides whether article 98 applies, ${ }^{50}$ but the procedure for doing so remains unclear. ${ }^{51}$ As to whether the state concerned is bound by this determination, no such power is explicitly given to the Court under this article (or Part 9 generally) and to imply such a 'farreaching' power would seem to be a stretch. ${ }^{52}$ Once again the question of the proper distinction between article 27 and article 98 re-emerges here. Under article 119 of the Rome Statute - which deals with Settlement of Disputes - a dispute 'concerning the judicial function of the Court [...] shall be settled by the decision of the Court'. 53 'Those who favour the article 27 waiver argument would likely see article 98 disputes as concerning the judicial function of the Court. ${ }^{54}$ On the hand, those who maintain a strict separation between the exercise of jurisdiction by the Court and cooperation obligations on states parties might consider such a dispute as a

\footnotetext{
50 The rule states:

When a requested State notifies the Court that a request for surrender or assistance raises a problem of execution in respect of article 98 , the requested State shall provide any information relevant to assist the Court in the application of article 98. Any concerned third State or sending State may provide additional information to assist the Court.

51 Akande (n 3) 431 suggests:

$[\mathrm{O}] \mathrm{n}$ a matter of such importance, it can only be assumed that the state concerned is entitled to a decision by the pretrial chamber. Although this issue is not specifically covered in the list of functions of the pretrial chamber in Article 57 of the Statute, Rule 195 arguably grants procedur52 Ibid. al rights to concerned third states or sending states in any hearings before the pretrial chamber.

53 Article 119 allows for two distinct procedures to be followed in the event of such disagreement. First, disputes over the judicial functions of the court must be settled by the court itself. Secondly, disputes that do not pertain to judicial functions - that arise between two or more state parties - and relate to the interpretation or application of the Statute, shall be referred to the Assembly of States Parties who may (a) seek to settle the dispute itself or; (b) make recommendations on further means of dispute settlement, notably including referral to the International Court of Justice in conformity with the Statute of that Court. See further A Pellet, 'Settlement of disputes' in A Cassese, P Gaeta and J Jones (eds), The Rome Statute of the International Criminal Court: A Commentary (OUP 2002) 1843.

${ }^{54}$ See, for example, Akande (n 3) 431.
} 
non-judicial one, governed by article 119(2) of the Rome Statute. Notably, the African Union has adopted the latter position, ${ }^{55}$ whilst non-African implementing legislation is equivocal on the matter. ${ }^{56}$ As a result, the position of the implementing acts on this question is therefore highly relevant.

Unfortunately, there is as yet no definitive ruling from the Court on the relationship between articles 27 and 98 of the Rome Statute and the effect of those provisions for non-party states. The Court's consideration of this issue to date has been oblique, if not obfuscatory, and as a result it is not clear exactly what approach it has taken. In its decision regarding the issuing of an arrest warrant for President Al-Bashir of Sudan, the Pre-Trial Chamber blithely noted:

[T] he current position of Omar Al Bashir as Head of a state which is not a party to the Statute, has no effect on the Court's jurisdiction over the present case. ${ }^{57}$

The Court went on to give four 'explanations' for its position, although none address the central question of the proper construction of the relationship between article 27(2) and article 98(1). This remarkably unsatisfactory discussion of this crucial issue by the Court is disappointing to say the least. Following the Prosecutor's successful appeal on the genocide charges, the Pre-Trial once again had an opportunity to address the immunity issue that it failed to take up. Proponents of both constructions of the article 27/98 relationship can conceivably rely on the Court's terse statement in support of their thesis: the article 27 waiver proponents interpreting it as rejecting the relevance of immunity outright, their counterparts focusing on the reference to the 'Court's jurisdiction', and not the cooperation of states parties. ${ }^{58}$ Then, when the latter were directly implicated by the debacle of AlBashir's visit to Kenya in August 2010 the Court elected to cite both the Rome Statute and the UN Charter in support of the 'clear obligation' on Kenya 'cooperate with the Court in relation to the enforcement of such warrants of arrest'. ${ }^{9}$ However, in October 2010, when Al-Bashir was expected to visit Kenya once again, the Pre-Trial Chamber (noting article 97) asked Kenya to 'inform the Cham-

\footnotetext{
55 See African Union, 'Ministerial Meeting of African States Parties to the Rome Statute of the ICC' (8-9 June 2009) Addis Ababa, MinICC/Legal. The AU have raised the article 98 issue - although not consistently - in its objections to the al-Bashir arrest warrant, as has the Arab League.

56 Akande (n 3) 431 notes: 'The national statutes that deal with the immunity of foreign officials when a request for arrest has been made by the ICC reveal that states have taken differing views on the identity of the body entitled to decide the issue'.

57 ICC Pre-Trial Chamber I, Prosecutor v Al Bashir, Decision on the Prosecution's Application for a Warrant of Arrest against Omar Hassan Ahmad Al Bashir (4 March 2009) ICC-02/05-01/09-3, 41 (emphasis added).

${ }^{58}$ Notably, the Pre-Trial Chamber ordered the registrar to transmit the 'request for cooperation' both to States Parties and Members of the Security Council; making it difficult to read into it support for the article 27 waiver argument. In any event, such requests can be made to non-states parties. See Rome Statute, art 87(5)(a).

59 ICC Pre-Trial Chamber I, Prosecutor v Al Bashir, Decision informing the United Nations Security Council and the Assembly of States parties to the Rome Statute about Omar Al-Bashir's presence in the territory of the Republic of the Kenya (27 August 2010) ICC-02/05-01/09-107.
} 
ber [...] about any problem which would impede or prevent the arrest and surrender of Omar Al-Bashir in case he visits the Republic of Kenya'. ${ }^{60}$ The impact of this on the immunity question is once again unclear. On the one hand, it could be read either as a rhetorical statement, on the other it might be read as a not-tosubtle hint to Kenya to '[notify] the Court that a request for surrender or assistance raises a problem of execution in respect of article 98', as required under Rule 195.

The upshot of this is that as yet there is no clear decision from the ICC on the relationship between articles 27 and 98 of the Rome Statute and the effect of those provisions for non-party states.

\section{Immunity, Cooperation and African Implementation Legislation}

\subsection{South Africa's Rome Statute Act (2002)}

South Africa's Rome Statute Act (2002) is silent on the relevance of immunity in relation to cooperation requests and the relationship between articles 27 and 98 . Contrary to Kenya and Uganda's implementing legislation, the Rome Statute Act's immunity provision focuses on the impact of immunity in domestic prosecutions and makes no mention of immunity in relation to cooperation with the ICC. What is more, the Act's immunity provision appears to address the question of immunity rationemateriae (not ratione personae), making it irrelevant to article $27(2)$ and article $98(1) \cdot 61$

In terms of section 8 of the ICC Act, when South Africa receives a request from the ICC for the arrest and surrender of a person for whom the ICC has issued a warrant of arrest, it must refer the request to the Director-General of Justice and Constitutional Development with the necessary documentation to satisfy a local court that there are sufficient grounds for the surrender of the person to The Hague. ${ }^{62}$ As we shall see when we consider Kenya and Uganda's implementation legislation, this is the point at which the question of article 98' s application would arise, however the Rome Statute Act (2002) makes no mention of article 98. It merely directs the Director-General to forward the request (along with the necessary

\footnotetext{
${ }^{60}$ ICC Press Release, 'Pre-Trial Chamber I requests observations from Kenya on the enforcement of warrants of arrest against Omar Al Bashir' (26 October 2010) ICC-CPI-20101026-PR589.

${ }^{61}$ The SA ICC Act (2002) s 4(2)(a) states, that notwithstanding

any other law to the contrary, including customary and conventional international law, the fact that a person [...] is or was a head of State or government, a member of a government or parliament, an elected representative or a government official $[\ldots]$ is neither: (i) a defence to a crime; nor (ii) a ground for any possible reduction of sentence once a person has been convicted of a crime.

See below.

62 SA Rome Statute Act (2002) s 8(1).
} 
documentation) to a magistrate who must endorse the ICC's warrant of arrest for execution in any part of the Republic. ${ }^{63}$

It is worth noting that in practice the South African government has taken the position that immunity is not a bar to cooperation, as evidence by the belated (and begrudging) revelation that the Al-Bashir arrest warrant had been endorsed by a South African magistrate, is active in the Republic and that President Al-Bashir would be arrested should he be present in the Republic. At no point was mention made of article 98, which could be construed as an implicit endorsement of the article 27 waiver 2.0 argument.

\subsection{Kenya's International Crimes Act (2008)}

In contrast, Kenya's International Crimes Act (2008) specifically addresses the relevance of immunity in relation to cooperation requests. Section 27(1) thereof titled 'Official capacity of person no bar to request' - states that

$[\mathrm{t}]$ he existence of any immunity or special procedural rule attaching to the official capacity of any person shall not constitute a ground for (a) refusing or postponing the execution of a request for surrender or other assistance by the ICC; (b) holding that a person is ineligible for surrender, transfer, or removal to the ICC or another State under this Act; or (c) holding that a person is not obliged to provide the assistance sought in a request by the ICC.

However, section 27(1) is subject to the provision of section 115 of the International Crimes Act, which addresses Requests involving conflict with other international obligations. ${ }^{64}$ In terms of this section:

If a request by the ICC for assistance to which this Part applies concerns persons who, or information or property that, are subject to the control of another State or an international organisation under an international agreement, the Attorney-General shall inform the ICC to enable it to direct its request to the other State or international organization. ${ }^{65}$

The provision goes on to state that the Minister may postpone the request for assistance in such circumstances. ${ }^{66}$

\footnotetext{
63 Ibid s 8(2).

${ }^{64}$ Kenya International Crimes Act (2008) s 27(2), states: 'Subsection (1) shall have effect subject to sections 62 and 115, but notwithstanding any other enactment or rule of law.' (emphasis added).

65 Ibid s 115(1).

${ }^{66}$ Kenya International Crimes Act (2008) s 115(2) states:

Where - (a) the ICC makes a request for assistance; (b) the ICC has not previously made a final determination on whether or not paragraph 1 of article 98 of the Rome Statute applies to that request; and (c) a request is made to the ICC to determine whether or not paragraph 1 of article
} 
These provisions of Kenya's International Crimes Act are remarkable for a number of reasons:

First, section 27 of the Act relates to immunity ratione personae $e^{67}$ and its relevance to requests for cooperation in arrest and surrender or assistance from the ICC (or extradition from third states) and not domestic prosecutions (contra South Africa's Rome Statute Act).

Second, the Act (section 115) expressly refers to article 98 of the Rome Statute and in doing so it arguably adopts an interpretation of the article 27/98 relationship that implicitly rejects the article 27 waiver argument. Section 115 is by no means perfect, it appears to imperfectly conflate article 98(1) ${ }^{68}$ and article 98(2) by referring to requests relating to 'persons who, or information or property that, are subject to the control of another State or an international organisation under an international agreement. This is different from article 98(1) which refers to 'obligations under international law with respect to the State or diplomatic immunity of a person or property of a third State'. What is more, the reference to persons, property or information 'subject to the control of another State' is novel and potentially casts the net far wider that traditional immunity ratione personae. However, these difficulties aside, section 115 clearly does not distinguish between persons coming from states parties to the Rome Statute, as the article 27 waiver argument requires. Notably, other implementing acts do make such a distinction. In terms of the United Kingdom's International Criminal Court Act (2001),

[a]ny state or diplomatic immunity attaching to a person by reason of a connection with a state party to the ICC Statute does not prevent proceedings [...] [related to arrest and surrender] in relation to that person. ${ }^{69}$

In contrast, where 'state or diplomatic immunity attaches to a person by reason of a connection with a state other than a state party to the ICC Statute' a waiver must be obtained from the state or organization concerned. ${ }^{70}$

Third, the International Crimes Act charges the Court with making a request to the 'third state' or organization. This will be done in terms of Rule 195 of the Court's Rules of Procedure and Evidence, which states that

[w] hen a requested State notifies the Court that a request for surrender or assistance raises a problem of execution in respect of article 98, the request-

98 applies to the request for surrender, the Minister may postpone the request for assistance until the ICC advises whether or not it wishes to proceed with the request for assistance.

${ }^{67}$ The title of the section specifically refers to article 27(2) of the Rome Statute.

68 Which it specifically refers to. See Kenya International Crimes Act(2008) s 115(2).

${ }^{69}$ UK International Criminal Court Act (2001) s 23(1) (UK ICC Act (2001)). According to section 23(6) 'state or diplomatic immunity' refers to

any privilege or immunity attaching to a person, by reason of the status of that person or another as head of state, or as representative, official or agent of a state, under- $[\ldots]$ (c) any rule of law derived from customary international law.

${ }^{70}$ UK ICC Act (2001) s 23(2). 
ed State shall provide any information relevant to assist the Court in the application of article 98.

What happens thereafter is not clear from the wording of section 115 . The most coherent reading suggests that if the request is refused by the third party and the Court decides not to proceed with the original request, then Kenya shall refused the original request for assistance. ${ }^{71}$ If the Court nevertheless decides to proceed with the original request regardless, then Kenya shall accede to it provided that 'there is no other ground for refusing or postponing the request'. ${ }^{72}$ This suggests that Kenya considers itself bound by the Court's decision in such circumstances.

Finally, Kenya's immunity provision makes it clear that personal immunity shall not be a bar to surrender of a person to another state as well, not merely the ICC. In this respect it might go beyond what is permissible under customary international law by allowing Kenya to extradite an official who would otherwise enjoy immunity at the request of a third country. In terms of the ICJ Arrest Warrant decision this would definitely amount to a violation of Kenya's obligations under customary international law to the 'sending state'.

\subsection{Uganda’s ICC Act (2010)}

Uganda's ICC Act (2010) addresses the issue of immunity in articles 25 and 26. Article 25(1), titled 'Official capacity of person no bar to request', states that

$[\mathrm{t}]$ he existence of any immunity or special procedural rule attaching to the official capacity of any person is not ground for - (a) refusing or postponing the execution of a request for surrender or other assistance made by the ICC; (b) holding that a person is ineligible for arrest or surrender to the ICC under this Act; or (c) holding that a person is not obliged to provide the assistance sought in a request by the ICC.

This is a carbon-copy of section 27 of Kenya's Rome Statute Act (2002), with the exception of the reference to surrender to states.

In terms of article 25(2) of Uganda's ICC Act (2010), this section is made subject to section $24(6)$ which states:

If the [Justice] Minister is of the opinion that the circumstances set out in article 98 of the [Rome] Statute apply to a request for provisional arrest, arrest and surrender or other assistance, he or she shall consult with the ICC and request a determination as to whether article 98 applies.

There are obvious similarities between this provision and Kenya's correlative provision. Both address immunity ratione personae (i.e article 27(2) of the Rome Statute)

\footnotetext{
71 Kenya International Crimes Act (2008) s 115(3).

72 Kenya International Crimes Act (2008) s 115(4).
} 
in relation to cooperation requests rather than domestic prosecutions (in almost identical terms).

Further, like Kenya, Uganda makes this provision subject to article 98 of the Rome Statute through section $24(6)$ but makes no distinction between requests relating to state parties to the ICC and those not party. In this respect it contradicts, or at least does not confirm, the article 27 waiver argument in the same way that Kenya's legislation does.

How section 24(6) will operate however is not clear ex facie. The provision grants the Minister the discretion to consult with the ICC and request a determination as to whether article 98 applies. ${ }^{73}$ This consultative process is closer to article 97 of the Rome Statute which provides that states must 'consult with the Court without delay' if they receive a request from the Court 'in relation to which it identifies problems which may impede or prevent the execution of the request'. Although the article goes on to list what some of these problems might be, the list is clearly illustrative and not exhaustive. ${ }^{74}$ The obvious question is to whom might the Justice Minister consult? In terms of section 3 of the ICC Act - which contains definitions - reference to 'the ICC' includes any of the organs of the Court (i.e. the Prosecutor, the Registry, Chambers or the Presidency). This would seemingly preclude him from asking the ASP to make such a determination under article 119 of the Rome Statute (as discussed above). The request for 'a determination' aspect however is closer to the procedure under article 98. Presuming this is the procedure that the Ugandan legislators where referring to then requests for a determination under section 24(6) of the ICC Act will be directed to the Court who will then make a determination on its applicability in the circumstances. Finally, unlike Kenya, Uganda chose to exclude extradition to 'other States' from this procedure.

${ }^{73}$ Contrast this with section 115 of Kenya's International Crimes Act (2008)which refers to 'a request [...] made to the ICC to determine whether or not paragraph 1 of article 98 applies to the request for surrender'.

74 Article 97 'Consultations':

Where a State Party receives a request under this Part in relation to which it identifies problems which may impede or prevent the execution of the request, that State shall consult with the Court without delay in order to resolve the matter. Such problems may include, inter alia:

(a) Insufficient information to execute the request;

(b) In the case of a request for surrender, the fact that despite best efforts, the person sought cannot be located or that the investigation conducted has determined that the person in the requested State is clearly not the person named in the warrant; or

(c) The fact that execution of the request in its current form would require the requested State to breach a pre-existing treaty obligation undertaken with respect to another State. 


\section{Immunity and Domestic Prosecutions under the Implementation Legislation of South Africa, Kenya and Uganda}

In terms of the principle of complementarity, the prosecution of Rome Statute crimes is expected to take place before domestic courts in the ordinary course of events, with the ICC intervening only when the state concerned is either unwilling or unable to do so. ${ }^{75}$ Therefore, while the Rome Statute does not oblige states to establish the necessary legal frameworks to undertake these prosecutions, these are key to the effective functioning of the Rome Statute system. To this end, a number of states parties (including South Africa, Kenya and Uganda) have elected to include a framework for domestic prosecution within their implementing legislation. This raises the important question of the place of immunity provisions under these domestic frameworks, and in particular immunity ratione personae given that (as discussed above) this continues to apply before domestic courts regardless of the crime(s) being prosecuted.

The starting point for determining the relevance of such immunity to the prosecution of Rome Statute crimes in South Africa, Kenya and Uganda is to consider the provisions of particular implementing legislation. However, this is not the only consideration. One must also consider the position of customary international law immunities in each particular legal order, which turns on the place of international law with that order and its relationship with domestic legal norms. As we shall see, the question of whether states are obliged as a matter of international law to provide certain officials with immunity is only half the question, the other is whether the domestic law of the states recognizes that obligation and enforces it. That is ultimately a constitutional matter.

Therefore, in order to determine the applicability of immunity in respect of domestic prosecutions in Kenya, South African and Uganda three questions must be asked:

(1) Does the implementation legislation address the issue of immunity vis-à-vis domestic prosecution?

(2) What is the status of customary international law (immunity) within that State?

(3) In the event of a conflict, how does the particular legal order address conflicts between domestic and international obligations?

Consequently, before considering the application of immunities in respect of the implementing legislation, and domestic law of South Africa, Kenya and Uganda generally, it is necessary to make the following general comments regarding the place of international law in domestic legal orders.

\footnotetext{
75 See Rome Statute, preamble, para 10 and art 17.
} 
The first thing to note is that the status of international legal obligations is a question of domestic law, international law does not dictate how such obligations must be given effect to. ${ }^{76}$ The second is that there is no uniformity of practice in this regard. Traditionally scholars have used monism and dualism to describe the relationship between national and international law, although the usefulness of this theoretical divide has been criticized. ${ }^{77}$

According to the monist school, there is one unified legal order rather than two distinct systems, that is: 'international and municipal law [...] must be regarded as manifestations of a single conception of law'. ${ }^{78}$ Therefore, international law is automatically incorporated into municipal law without any act of adoption or transformation'. ${ }^{79}$ Accordingly, on this view, municipal courts are obliged to apply international law directly and no 'act of adoption by the courts or transformation by the legislature' is required. ${ }^{80}$ The dualist school emphasises that the two are distinct legal regimes. Therefore, international law must be applied by domestic courts only if 'adopted' by such courts or 'transformed' into local law by legislation. ${ }^{81}$ When municipal law provides that international law applies in whole or in part within the jurisdiction, this is merely an exercise of the authority of municipal law, an adoption or transformation of the rules of international law. ${ }^{82}$ In this way a rule of international law can never per se become part of the law of the land; it must be made so by the express or implied authority of the state. ${ }^{83}$

Further, as far as customary international law is concerned two approaches exist. The first, and more prominent, is the doctrine of incorporation in terms of which 'customary rules are to be considered part of the law of the land and enforced as such, with the qualification that they are incorporated only so far as is not inconsistent with Acts of Parliament or prior judicial decisions of final authority'. ${ }^{84}$ Under this doctrine customary international law is part of the domestic law without

\footnotetext{
76 As Denza notes, '[F]or each national legislature and court, the starting point for any examiniation of the relationship [between international and domestic law] is its own constitution'. E Denza, 'The Relationship Between International and National Law' in M Evans (ed), International Law (CUP 2010). Although it does require states to take such measure to give effect to those obligations in certain instances. See Article 88 of the Rome Statute.

77 Denza (ibid 421) notes:

There is no indication that either theory has had a significant input into the development will revision of national constitutions, into the debates in national parliaments about the ratification of international agreements, or into the decisions of national courts on questions of international law. Except as shorthand indications of the general approach within a particular state of implementation or application of international rules, these theories are not useful in examining the relationship between international law and national laws.

${ }^{78}$ J Dugard, International Law: a South African Perspective (3rd edn, Juta 2006) 47.

79 Ibid 43.

80 Ibid.

${ }^{81}$ Ibid 47.

82 I Brownlie, Principles of Public International Law (OUP 2008) 32.

${ }^{83}$ Dugard (n 78) 47.

${ }^{84}$ Brownlie (n 82) 41.
} 
further action by the legislature. ${ }^{85}$ Conversely, the doctrine of transformation is based on a strict dualist conception of international and national law, in terms of which before any rule or principle of international law can have any effect within the domestic jurisdiction, it must be expressly and specifically 'transferred' into municipal law by the use of the appropriate constitutional machinery, such as an act of parliament. ${ }^{86}$

Insofar as monist countries are concerned, the ICC cooperation obligations (and the 'waiver' contained in article 27) will automatically part of the domestic legal order. ${ }^{87}$ However, the situation is different with dualist states, as they require that their international legal obligations to be incorporated into the domestic legal order in order for them to be binding domestically. Three African states have adopted such legislation: South Africa, Kenya and Uganda. Although other dualist African ICC States Parties might rely on the absence of such legislation for not cooperating with the Court, as a matter of international law this domestic deficiency does not affect their obligations to cooperate under the Rome Statute, nor can it mitigate the wrongfulness of their non-cooperation under international law. ${ }^{8} \mathrm{How}-$ ever, any breach of an international obligation - be it for a failure to cooperate in circumstances when they are obliged to do so or violating the immunity of a foreign official - will take place 'only when the state concerned fails to observe its obligations on a specific occasion'. ${ }^{89}$

\subsection{South Africa's Rome Statute Act (2002)}

The position of South Africa is as follows: The ICC Act provides that notwithstanding

any other law to the contrary, including customary and conventional international law, the fact that a person [...] is or was a head of State or government, a member of a government or parliament, an elected representa-

\footnotetext{
85 M Shaw, International Law (6nd edn, CUP 2008) 140.

86 Ibid 139.

87 The situation is somewhat complicated in the case of the Rome Statute as, even in monist countries, the obligations contained therein require domestic measures to be adopted in order to facilitate cooperation with the Court.

${ }^{88}$ It is a well-established principle of international law that a state cannot rely on the provisions of its domestic law in order to justify the breach of an international obligation. See article 27 of the Vienna Convention on the Law of Treaties, 1155 UNTS 331 (1969), 23 May 1969, entered into force 27 January 1980; and Advisory Opinion of the Permanent Court of International Justice of 4 February 1932 in the Case concerning the Treatment of Polish Nationals and other persons of Polish origin or speech in the Danzig Territory. P.C.I.J., Series A/B, No. 44, 24-25.

${ }^{89}$ Brownlie (n 82) 35 argues that:

Arising from the nature of treaty obligations and from customary law, there is a general duty to bring internal law into conformity with obligations under international law [...] However, in general a failure to bring about such conformity is not in itself a direct breach of international law $[\ldots]$.
} 
tive or a government official [...] is neither - (i) a defence to a crime; nor (ii) a ground for any possible reduction of sentence once a person has been convicted of a crime..$^{90}$

Most commentators have interpreted this provision as removing immunity before South African courts. ${ }^{91}$ Dugard and Abraham argue that section 4(2)(a) of the ICC Act represents a choice by the legislature not to follow the 'unfortunate' Arrest Warrant decision, 'of which it must have been aware'. ${ }^{92}$

However, this provision is clearly modelled on article 27(1) of the Rome Statute - which deals with the irrelevance of official capacity as a defence or as a ground for the reduction of sentence - and not article 27(2), which deals with personal immunity. ${ }^{93}$ Therefore, arguably while 4(2)(a) of the ICC Act effectively removes functional immunity of persons, it does not address personal immunity.

As far as the status of customary international law immunity under South African law is concerned, section 232 of the Constitution makes customary international law part of South African law. Therefore, whilst South Africa is by-and-large a dualist state ${ }^{94}$, it follows the doctrine of incorporation insofar as customary international law is concerned. Applying this to the question of immunity, if section 4(2)(a) of the Rome Statute Act (2002) is understood as removing immunity ratione personae for international crimes then it would prima facie conflict with the applicable customary rules. However, section 232 conditions the applicability of customary international law as follows: 'Customary international law is law in the Republic unless it is inconsistent with the Constitution or an Act of Parliament. Therefore, if the Rome Statute Act (2002) is interpreted as removing immunity ratione personae then it would do so notwithstanding the customary international law obligations on South Africa to observe it.

As a result, the question of the relevance of immunity ratione personae for domestic prosecutions under the Rome Statute Act (2002) depends wholly on the interpretation give to article 4(2)(a) of that Act. The argument made her is that this provision is based on article 27(1) of the Rome Statute and therefore relates to im-

90 SA ICC Act (2002) s 4(2)(a). See M du Plessis, 'South Africa's implementation of the ICC Statute: An African example' (2007) 5(2) JICJ15.

${ }^{91} \mathrm{Du}$ Plessis (ibid) notes:

In terms of the Act, South African courts, acting under the complementarity scheme, are thus accorded the same power to 'trump' the immunities which usually attach to officials of government as the International Criminal Court is by virtue of article 27 of the Rome Statute.

92 See J Dugard and G Abraham, 'Public International Law' (2002) Annual Survey of South African Law 140, 166.

${ }^{93}$ Article 27(2) reads: 'Immunities or special procedural rules which may attach to the official capacity of a person, whether under national or international law, shall not bar the Court from exercising its jurisdiction over such a person.'

${ }^{94}$ Section 231(4) of the Constitution of South Africa reads:

Any international agreement becomes law in the Republic when it is enacted into law by national legislation; but a self-executing provision of an agreement that has been approved by Parliament is law in the Republic unless it is inconsistent with the Constitution or an Act of Parliament. 
munity ratione materiae only, however this is by no means the orthodox interpretation amongst academics. One argument that might be raised in favour of the interpretation of this section adopted here is based on the interpretive presumption contained in section 233 of the Constitution, which states: When interpreting any legislation, every court must prefer any reasonable interpretation of the legislation that is consistent with international law over any alternative interpretation that is inconsistent with international law'. The counter argument to this might be a teleological one, to the effect that customary international law personal immunity is contrary to spirit, purport and object of South Africa's Constitution.

\subsection{Kenya's International Crimes Act (2008)}

As far as Kenya is concerned, section 7 of the International Crimes Act (2008) incorporates most of the General Principles of Criminal Law contained in Part 3 of the Rome Statute, 'with the necessary modifications', for the purposes of domestic prosecutions under the Act. Further it, gives these General Principles precedence over the relevant Kenyan laws. ${ }^{95}$ However, the Act excludes article 27 in its entirety from the list of General Principles that apply in such circumstances. This omission is remarkable as nowhere else in the International Crimes Act (2008) is the question of immunity addressed as far as domestic prosecutions are concerned.

The role of international law generally, and customary international law in particular, is more complex. Under the 1963 Constitution Kenya was a dualist state. To this end it adopted the International Crimes Act (2008) in order to 'incorporate' the Rome Statute of the ICC into its domestic law and provide for its implementation. That Act - which came into force on 1 January 2009 - states that certain sections of the Rome Statute, including those relating to international co-operation and judicial assistance, shall 'have the force of law in Kenya'. Therefore, under its own law Kenya is under an obligation to arrest and surrender person's to the ICC in respect of whom the Court has issued a warrant of arrest.

However, the new Kenyan Constitution - which came into force on 27 August 2010 - changed all that. In terms of article 2(6) of the New Constitution: 'Any treaty or convention ratified by Kenya shall form part of the law of Kenya under this Constitution.' ${ }^{96}$ In effect, this article converted Kenya into a 'monist' state. The Commission for the Implementation of the Constitution - mandated under Section 5(6) of the 6th Schedule of the Constitution to inter alia monitor, facilitate and oversee the development of legislation and administrative procedures required to implement this Constitution' - leaves little room for doubt in this regard, noting:

\footnotetext{
${ }^{95}$ Kenya ICC Act (2008) s 7(2)(b)(i).

96 Article 2(5) of the Constitution of Kenya 2010 goes on to note: 'The general rules of international law shall form part of the law of Kenya'.
} 
This provision while recognizing that all international and regional instruments, to which Kenya is party to, form part of the laws of Kenya also has the effect of making Kenya a Monist state, which is a shift from the Dualist state which Kenya was prior to the promulgation of the Constitution 2010. [...] This is premised upon the recognition of a unity between international and national laws, among monist states. ${ }^{97}$

Further, section 2(5) of the Constitution provides the ' $[\mathrm{t}]$ he general rules of international law shall form part of the law of Kenya'. The reference to general rules is confusing, but given the intentional shift to a monist regime it can reasonably be understood as referring to customary international law. If this is accepted then the immunity ratione personae enjoyed by heads of states and other officials under customary international law would apply in Kenya without need for further legislative action.

As immunity is not addressed in the International Crimes Act (2008), there is no conflict between norms in this regard.In any event, article 2(4) of the Kenyan Constitution states: 'Any law [...] that is inconsistent with this Constitution is void to the extent of the inconsistency, and any act or omission in contravention of this Constitution is invalid'. In this regardthere is no hierarchy established between customary international law and ordinary legislation such as the International Crimes Act.

${ }_{97}$ Commission for the Implementation of the Constitution, 'Understanding Article 2(6) of the Constitution' <http://cickenya.org/content/understanding-article-26-constitution> accessed 12 June 2011. With this in mind, article 94(5) and (6) make parliamentary approval necessary for the ratification process. Article 94(5) states: 'no person or body, other than Parliament, has the power to make provision having the force of law in Kenya except under authority conferred by this Constitution or by legislation'. This, according to the CIC, means that ' $[\mathrm{n}] \mathrm{o}$ treaty therefore can be ratified without prior approval by Parliament'. To this end a Bill will soon be presented to parliament that 'to streamline the process of ratification of treaties in Kenya to ensure that Kenya's international obligations there under are fulfilled'. Ratification of Treaties Bill(2011) s 3. Gathii notes further:

This clause effectively removes the requirement of enacting domestic implementing legislation pursuant to a treaty unless Parliament and the Executive develop practice to the contrary. This seems to be the intention behind the 2010 Constitution, which omits provisions contained in prior drafts that contemplated that Parliament would have been authorized to consider and approve treaties and international agreements and the President empowered to sign instruments of consent of the Republic to be bound by treaties and international agreements. In my view, the omission of these provisions that were contained in the Harmonized Draft Constitution demonstrates that the drafters thought it unnecessary to mention the power of the President and Parliament with respect to authorizing or signing treaties since these were automatically deemed to be a part of the laws of Kenya under Articles 2(5) and 2(6). As a consequence of Article 2(6), a treaty entered into by the Executive may lay the basis for a cause of action or the granting of a remedy without domestic implementing legislation by the National Assembly.

James Gathii, 'Making global treaties part of the Kenyan Constitution presents a legal quagmire and leaves implementation loopholes' (March 2011) Nairobi Law Monthly. 


\subsection{Uganda's International Crimes Act (2002)}

Like Kenya, Uganda's International Crimes Act (2002) explicitly excludes the operation of article 27 in respect of domestic prosecutions of genocide, war crimes and crimes against humanity under the Act. In terms of article 19(1), certain general principles of criminal law contained in the Rome Statute apply to domestic prosecutions under the Act, 'with any necessary modifications'. However, this list excludes article 27 from its ambit.

As to the status of international law in Uganda, the first thing to note is that Uganda is a dualist state. ${ }^{98}$ Pursuant to section $123(2)^{99}$ of the Constitution, Uganda's parliament passed the Ratification of Treaties Act (1998) which provides that Cabinet shall ratify all treaties, except for treaties relating to armistice, neutrality, peace or those that require an amendment to the Constitution; which must be ratified by parliament resolution. ${ }^{100}$ Thereafter, parliament passes the relevant legislation to give the treaty the force of law in Uganda. This was the process followed in respect of the ICC Act (2010). In practice, despite an 'unapologetically dualist'101 approach historically, in recent times Ugandan courts have become more open to international law principles although their theoretical basis for doing so is not clear. ${ }^{102}$

The Constitution does not address the status of customary international law in Ugandan law, save for stating the Uganda's foreign policy shall be based on 'respect for international law and treaty obligations'. ${ }^{103}$ However, on balance it is safe to assume that, as a dualist state, Uganda follows the doctrine of transformation in respect of customary international law. To the extent that customary international law does apply in Uganda, section 2(2) of the Constitution states that 'any other law or any custom is inconsistent with any of the provisions of this Constitution, the Constitution shall prevail, and that other law or custom shall, to the extent of the inconsistency, be void'. This is a narrower clause than South Africa's Constitution - which conditions the application of customary international law on its conformi-

\footnotetext{
98 See further Republic of Uganda, Report of the Republic Of Uganda to the Commission On Human And Peoples' Rights, presented at the 39th Ordinary Session of The Commission On Human And Peoples' Rights, Banjul, The Gambia (May 2006) 7.

99 Which states: 'Parliament shall make laws to govern ratification of treaties, conventions, agreements or other arrangements made [by the President][...]'.

100 Ratification of Treaties Act (1998), Act no 5 of 1998, s 2.

${ }^{101}$ Mulyagonja-Kakooza, 'International Human Rights and the Courts in Uganda', paper presented at a Symposium on the Application of International Law, Kampala (29 July 2010) (unpublished).

102 As Mulyagonja-Kakooza (ibid) notes:

The jurisprudence of the Ugandan courts, especially in the past decades has become replete with inundations and practical application of international law. Interestingly, the courts have not been bogged down by the scholarly debate about theories of the relationship between international law and municipal law. Nonetheless, the courts' application of international law does raise the question of the parameters or premise for the application. Notably, the reliance on international law has primarily been in respect of human rights and constitutional issues.

${ }^{103}$ Constitution of Uganda 1995, art XXVIII(i)(b).
} 
ty with both the Constitution and Acts of Parliament. The only argument against the application of customary international immunities then would have to be based on a teleological interpretation of the Constitution.

\section{Concluding Remarks}

From the above discussion it is clear that the issue of immunity remains one of the most divisive and debated aspects of the Rome Statute; not only in terms of its relevance for state cooperation under Part 9, but also for domestic prosecutions in pursuance of the principle of 'positive complementarity'. Given the Court's current clients, and the stated purpose of the ICC to bring those bearing the greatest responsibility for international crimes to justice, this ambiguity could not be more unsettling for the Court and states parties alike. This uncertainty has filtered into the implementing legislation of South Africa, Kenya and Uganda, which themselves have further muddied the water in this regard.

While clarity remains illusive these implementation instruments have a role to play in debate regarding how this issue is to be resolved. Ultimate responsibility for doing so seemingly lies with the Court itself, something which it has awkwardly refused to shoulder to date. In any event, ICC states parties from Africa should endeavour to ensure clarity within and between their implementation legislation (both current and future) in order to make sure their positions on immunity which appear to be somewhat at odds with the orthodox position - are given the fullest consideration possible in this process. 



\title{
The International Criminal Court Factor on Transitional Justice in Kenya
}

\author{
Evelyne Owiye Asaala
}

\begin{abstract}
On 27 December 2007, Kenya held its General Elections which were marred by violence. The post-election violence period witnessed the establishment of the Kenya National Dialogue and Reconciliation Committee (KNDRC). This became the avenue through which the then ruling party (Party of National Unity) and the opposition (Orange Democratic Movement) discussed an agenda for power sharing as well as specific issues of reform. In the course of the deliberations, a need for the establishment of various transitional justice mechanisms came to the fore. Thus, the KNDRC agreed on the establishment of a truth mechanism, a prosecution mechanism and a constitutional reform process. As Kenya oscillated between its gruesome past and its probable transition, the Kenyan Parliament enacted the International Crimes Act in 2008 which law incorporated the Rome Statute.

This contribution takes further the discourse on the implementation of the Rome Statute in Kenya by looking at how the process of implementation and in particular the ICC aspect is impacting on the various transitional justice mechanisms - the Truth Justice and Reconciliation Commission, constitutional, legal and institutional reform process and the prosecution outfit. In addition, the contribution looks at the manner in which the ICC has informed the local perspectives on justice. It also analyses the principle of complementarity and the extent to which Kenya has adhered to it.
\end{abstract}




\section{La Cour Pénale Internationale Facteur de Justice de Transition au Kenya}

\section{Résumé}

Le 27 Décembre 2007, le Kenya a tenu des élections générales qui ont été marquées par des violences. La période de violence post-électorale a vu la création du Comité de Dialogue National et de Réconciliation Kenyan (KNDRC). C'est devenu le moyen par lequel le parti alors au pouvoir (Parti d'union nationale) et l'opposition (Mouvement démocratique orange) ont discuté d'un agenda pour le partage du pouvoir ainsi que des questions spécifiques de réforme. Au cours des délibérations, la nécessité de créer divers mécanismes de justice transitionnelle s'est imposée comme une priorité. Ainsi, le KNDRC a convenu de mettre en place un mécanisme de vérité, un mécanisme de poursuite judiciaire et un processus de réforme constitutionnelle. Alors que le Kenya oscillait entre son passé horrible et sa transition probable, le Parlement kenyan a adopté la Loi sur les crimes internationaux en 2008 dont le texte incorporait le Statut de Rome.

Cette contribution renforce le processus de mise en cuvre du Statut de Rome au Kenya en examinant la façon dont le processus de mise en cuvre et en particulier l'aspect de la CPI peut affecter les différents mécanismes de justice transitionnelle - la Commission de Réconciliation et de Justice Vérité, le processus de réforme constitutionnelle, juridique et institutionnelle et le système de poursuite judiciaire. De plus, la contribution se penche sur la manière dont la CPI a informé les perspectives locales sur la justice.

Elle analyse également le principe de la complémentarité et la mesure dans laquelle le Kenyay a adhéré.

\section{Introduction}

The study sets of by first, laying down its contextual background. It then explores the principle of complementarity and how the challenges facing the implementation of the International Crimes Act (the Act) ${ }^{1}$ has made the realization of this principle elusive. Of particular concern is whether Kenya has paid due regard to this principle in adherence to its obligations under the Act. Third, this chapter undertakes a critique of the on-going prosecution efforts. Fourth, an analysis of Truth and Reconciliation mechanisms and the International Criminal Court factor (ICC, the Court) are considered. Fifth, is a critique of the constitutional reform process and its implementation period vis à vis the role of the ICC. The sixth part

\footnotetext{
1 Act no 16 of 2008. This Act of Parliament seeks to domesticate the Rome Statute. Kenya ratified the Rome Statute (Rome Statute of the International Criminal Court, 2187 UNTS 90, 17 July 1998 , entered into force 1 July 2002 [Rome Statute]) on 5 March 2005.
} 
looks at the role of the ICC in shaping the various perspectives of justice in Kenya. The study finally draws several conclusions.

\section{Contextual background}

The adoption of the Rome Statute of the International Criminal Court (the Rome Statute) on 17 July 1998 was agenda setting in the sphere of international criminal justice. This not only informed subsequent developments in this province but has variously influenced the numerous ways in which the notion of transitional justice has been conceptualized. Similarly, the Court has largely inspired the form, conduct as well as the manner in which other transitional mechanisms have emerged and operated. Of concern to this contribution is firstly, the introduction of the principle of complementarity. ${ }^{2}$ Even though several scholars have attempted to interpret this principle, the extent to which the same has played out in the Kenyan context is worth considering. Likewise, is the manner in which the ICC is influencing the emergence and operation of other transitional justice mechanisms as well as the various perceptions on justice in Kenya.

27 December 2007 was a defining moment for Kenya as the nation held its general elections. The aftermath of this election was marked by violence sparked by allegations of a rigged election. ${ }^{3}$ It is estimated that more than 1300 people succumbed to the violence and not less than 650,000 were displaced. ${ }^{4}$ As the violence escalated - from 29 December 2007 to February 2010 - the need for emergency measures to address the political stalemate could not have been underestimated. Several regional attempts at bringing the then ruling party (the Party of National Unity) and the then opposition party (the Orange Democratic Movement) to a negotiating table were initiated. ${ }^{5}$ Initially, these efforts bore no fruits.

In January 2008, the AU mandated a peace mediation process in Kenya. ${ }^{6}$ As a result, the Kenya National Dialogue and Reconciliation Committee (KNDRC)

\footnotetext{
2 Rome Statute, preamble, art 1 and 17.

${ }^{3}$ European Union Election Observation Mission, Final Report on Kenya, General Elections 27 December 2007 (3 April 2008) 36

$<$ http://www.eueomkenya.org/Main/English/PDF/Final_Report_Kenya_2007.pdf> accessed 1 May 2012.

${ }^{4}$ Internal Displacement Monitoring Centre (IDMC), 'Speedy reforms needed to deal with past injustices and prevent future displacement' (10 June 2010) <http://www.internaldisplacement.org/countries/kenya $>$ accessed 26 October 2011; see also Commission of Inquiry into the Post Election Violence (CIPEV) Final Report (15 October 2008) pp. 472-475 $<$ http://www.dialoguekenya.org/index.php/reports/commission-reports.html $>$ accessed 1 May 2012.

5 There had been aborted attempts at mediating the crisis by Archbishop Desmond Tutu and Mr. Kufuor - the then outgoing AU chairman and Ghanaian President.

${ }^{6}$ Upon AU's invitation, Mr. Kofi Anan assumed the mantle as AU's special adviser and chief mediator of the mediation process. The other eminent African personalities in the panel of negotiations included Benjamin Mkapa (former president of Tanzania), and Graca Matchel (former South African
} 
wasestablished under the leadership of the former United Nations (UN) Secretary General - Kofi Anan. This commission was faced with two essential demands. First, was the need to stop the violence as soon as it was possible. Second, was the necessity of putting in place mechanisms that would enable Kenya transcend from its past to a just future. Agreeing that impunity was the common denominator informing the pre-requisites to transitional justice, a further agreement was reached as to the establishment of various transitional justice mechanisms. ${ }^{7}$ These included a Truth Justice and Reconciliation Commission (TJRC) ${ }^{8}$ and a comprehensive Constitutional, legal and institutional reform process.

Regarding the need for a prosecuting outfit, the KNDRC agreed upon the establishment of a Commission of Inquiry into the Post-Election Violence (CIPEV). ${ }^{9}$ This commission was duly established ${ }^{10}$ and was mandated to inter alia investigate the violence and make recommendations on any probable legal redress. ${ }^{11}$ In its final report, CIPEV underscored the need for a Special Tribunal for the prosecution of those who bore the greatest responsibility for crimes against humanity arising from the post - election violence. ${ }^{12}$ In the event that the efforts towards establishing an effective tribunal were frustrated, CIPEV further recommended the referral of the names of the alleged perpetrators to the ICC. ${ }^{13}$

To achieve the objectives of the TJRC and the constitutional, legal and institutional reform processes, certain legal frameworks were put in place. ${ }^{14} \mathrm{On}$ the other hand, the objectives on prosecution foresaw the enactment of the International Crimes Act (the Act). The route of implementing this Act has, nonetheless, not been a smooth one. This is particularly so in relation to the role of the ICC on the on-going transitional justice mechanisms - prosecution, constitutional reform process and the TJRC. Even so, this discourse is privy to the concerns as to whether Kenya is a state in transition.

first lady). Upon Anan's request, President Jakaya Kikwete of Tanzania and the then new chairman of $\mathrm{AU}$ was included in the process.

7 KNDRC, Agreement on agenda item three: How to resolve the political crisis (14 February 2008) 3 <http://www.dialoguekenya.org/index.php/agreements.html> accessed 1 May 2012.

8 Ibid.

${ }^{9}$ KNDRC, Agreement:[Commission[d]

$<$ http://www.dialoguekenya.org/Agreements/Commission\%20of\%20Postelection\%20Violence.pdf> accessed 2 May 2012.

${ }^{10}$ Kenya Gazette, Notice 4473 vol cx-no 4 (23 May 2008).

11 Ibid.

12 CIPEV Final Report (n 4) part IV.

13 Ibid 473.

${ }^{14}$ The Truth Justice and Reconciliation Act (Act no 6 of 2008 [TJR Act 2008]) establishing the TJRC; the Constitution of Kenya Review Act (Act no 9 of 2008) and the Constitution of Kenya (Amendment) Act (Act no 3 of 2008); the latter sought to entrench the political agreements arrived at in the KNDRC in the constitution. The former was to facilitate the completion of the Constitutional Review process. 


\section{Kenya in a transitional context}

In this regard, it has been argued elsewhere that the question as to whether a country is transitional is historical and contextual. ${ }^{15}$ Thus,

a state could be said to be in transition when: it has been under a regime that massively violates the rights of its citizens; it has encountered mass violence or has been in an armed conflict; and such a state is making attempts to deal with its past in order to democratize its future. ${ }^{16}$

Such transitional efforts could embody: TRCs, amnesties, prosecutions, purges, institutional reforms, constitutional amendments et cetera.

The post-independence Kenyan state is characterized by horrendous human rights abuses. In this state, mass political assassinations $;{ }^{17}$ torture, ${ }^{18}$ inter-ethnic violence sanctioned by the state, ${ }^{19}$ arbitrary arrests and detentions, ${ }^{20}$ extra judicial

\footnotetext{
15 Evelyne Asaala, 'Exploring transitional justice as a vehicle for social and political transformation in Kenya' (2010) 10(2) African Human Rights Law Journal 382; See also Ruti Teitel, Transitional Justice (Oxford University Press 2000) 219. Fionnuala Ni Aolain and Colm Campbell, 'The paradox of transition in conflicted democracies' (2005) 27 Human Rights Quaterly (HRQ) 172. Makau Mutua (Chairperson), Report of the Task Force on the Establishment of a Truth, Justice and Reconciliation Commission (26 August 2003), pp. $19 \mathrm{ff}$.

<http://marsgroupkenya.org/pdfs/2008/march_2008/Kenya_Report_of_the_Task_Force_on_the_ Establishment_of_a_Truth_Justice_and_Reconciliation_Commission_August_26th_2003.pdf> accessed 20 June 2012.

16 Ibid.

17 John Londale, 'Moral and Political argument in Kenya' in Bruce Berman, Dickson Eyoh and Will Kymlicka (eds) Ethnicity and democracy in Africa (James Currey Publishers 2004) 91; See also GithuMuigai, 'Ethnicity and the renewal of competitive politics in Kenya' in Harvey Glickman (ed) Ethnicity, conflict and democratization (African Studies Association Press 1995) 171; See also Rok Ajulu, 'Thinking through the crisis of democratization in Kenya: a response to Adar and Murunga' (2000) 4(2) African Sociological Review137. These scholars document some of the political murders and assassinations that occurred during the Kenyatta regime; for example: the disposal of JM Kariuki in 1975, the assassination of Tom Mboya in July 1969, the public shooting of the radical Pio Gama Pinto. These political analysts have further pointed fingers to the Kenyatta regime for the death of other key political opponents who died in questionable circumstances; some of these include: Ronald Ngala and Argwins Kodhek. See also Joe Khamisi, The polititics of betrayal (Trafford 2011) 233 further writes on the assassination of Dr Odhiambo-Mbai - a constant critic of the Kibaki administration - during the Kibaki regime.

18 Rok Ajulu (n 17)143. Ajulu documents on the government establishment of what has come to be called 'torture chambers' in which political opponents were subjected to gruesome torture after moot trials (popularly known as mwakenya trials).

${ }^{19}$ Report by the National Christian Council of Kenya, The cursed arrow: contemporary report on the politicized land clashes in Rift Valley, Nyanza and western Provinces (1992); See also report by Africa Watch, Divide and Rule: State sponsored ethnic violence in Kenya (1993).

${ }^{20}$ Rok Ajulu (n 17) notes that in 1983, the Government adopted a policy of 'detention without trials' under which several people, especially political opponents, were arrested and subjected to detention under torture.
} 
police killings, ${ }^{21}$ banning of opposition parties, irregular allocation of land and hideous economic crimes became the order of the day. ${ }^{22}$ These massive human rights violations coupled with therecent violence of 2007, ushered in a transitional momentum. Indeed, the events following the post-election violence of 2007 foresaw the establishment of transitional justice initiatives - the TJRC, prosecution initiatives, constitutional and institutional reforms. Kenya is therefore a society in transition.

\section{The principle of complementarity}

One of the features of the Rome Statute is that of the doctrine of shared responsibility with member states in prosecution of crimes within its jurisdiction. Underlying this doctrine is the principle of complementarity. There is no precise universal meaning of this concept. Several schools of thought exist in so far as the interpretation of this principle is concerned. One school argues that complementarity is a system where the ICC itself acts as a reinforcement of the efforts of national systems in combating the culture of impunity and bringing defaulters to justice; it therefore relies principally, on states to investigate and prosecute persons accused of the ICC crimes under its domestic criminal justice system. ${ }^{23}$ Thus, the ICC and state parties to the Statute have a mutual responsibility to bring to justice perpetrators of the worst crimes, neither party having exclusive jurisdiction. Related to this, is another school of thought that holds the concept of complementarity as referring to the primacy of the national courts over the ICC as far as the jurisdiction to investigate and try alleged offenders is concerned. ${ }^{24} \mathrm{~A}$ similar interpretation would be attached to the provisions of the Rome Statute which underscores the fact that the Court shall be complementary to 'national criminal jurisdictions'. ${ }^{25}$ In both instances, the ICC can only be seized of the matter in the manner prescribed under the Statute. ${ }^{26}$

The principle of complementarity often manifests itself when the Court is determining the admissibility of a case. Admissibility on the other hand is 'the criterion which enables the determination of whether it is for a national jurisdiction or

21 KNCHR, Follow-up Report on Extra Judicial Killings and Disappearances (August 2008) $<$ http://nd.edu/ ndlaw/cchr/news/FinalReport.pdf > accessed 20 June 2012.

${ }^{22}$ Chris Odhiambo-Mbai, 'The rise and fall of the autocratic state in Kenya' in Walter Oyugi, Peter Wanyande and Chris Odhiambo-Mbai (eds) The politics of transition in Kenya: from KANU TO NARC (Heinrich Boll Foundation 2003) 65. Mbai writes on the famous 'Goldenberg scandal', the 'Anglo leasing scandal' and 'the Grand regency scandal' embezzled Government's large sums of money.

${ }^{23}$ Henry Steiner and Philip Alston, International human rights in context: law, politics, morals (Oxford University Press 2007) 1299.

${ }^{24}$ Cherif Bassiouni, 'Introduction to international criminal law' in Cherif Bassiouni, Post-Conflict Justice, International and Comparative Law Series (Transnational Publishers, 2002)58.

${ }^{25}$ Rome Statute, preamble para 10 and art 1.

${ }^{26}$ Rome Statute, art 17(1)(a). 
for the Court to proceed. ${ }^{27}$ It is thus a tool that allows the implementation of the principle of complementarity. ${ }^{28}$

\subsection{Admissibility}

Before commencement of any trial, the Court must satisfy itself of two things. First, it has to establish that it has jurisdiction ${ }^{29}$ over the matter and secondly, it has to determine the issue of admissibility of the matter. ${ }^{30}$ While the former prerequisite is beyond the scope of this chapter, the admissibility of a case before the ICC can be challenged by an accused person, the state having jurisdiction over the matter and a state that is not a party to the Rome Statute but has accepted its jurisdiction. ${ }^{31}$ The Court can also determine the question of admissibility on its own motion. ${ }^{32}$

The Rome Statute provides for the procedure of admissibility:

$[\ldots]$ The Court shall determine that a case is inadmissible where:

(a) The case is being investigated or prosecuted by a State which has jurisdiction over it, unless the State is unwilling or unable genuinely to carry out the investigation or prosecution;

(b) The case has been investigated by a State which has jurisdiction over it and the State has decided not to prosecute the person concerned, unless the decision resulted from the unwillingness or inability of the State genuinely to prosecute;

(c) The person concerned has already been tried for conduct which is the subject of the complaint, and a trial by the Court is not permitted under article 20, paragraph 3;

(d) The case is not of sufficient gravity to justify further action by the Court. ${ }^{33}$

27 ICC Pre Trial Chamber II, Prosecutor v Kony and others, Decision on the admissibility of the case under article 19 (1) of the Statute (10 March 2009) ICC-02/04-01/05, para 34.

${ }^{28}$ Ibid.

29 Rome Statute, art 19. ICC Pre-Trial Chamber I, Situation in the Democratic Republic of Congo, ex parte, Decision on the prosecutor's application for warrants of arrest, article 58 (10 February 2006) ICC01/04-520-Anx2, para 24, the Court established the conditions that a crime must fulfill in order to fall within its jurisdiction. First, the crime must be one of those mentioned under article 5 of the Statute, the crime must have been committed within the time period laid down in article 11 of the Statute and the crime must meet one of the two alternative conditions described in article 12 of the Statute.

${ }^{30}$ Rome Statute, art 17 and art 19.

31 Rome Statute, art 19(2).

32 Rome Statute, art 19(1).

33 Rome Statute, art 17(1). 
Thus, the admissibility of a case is a factual determination as at the time of the application challenging it. ${ }^{34}$ This will depend on firstly, the investigating or prosecuting activities of the state concerned as at the time of the application. ${ }^{35}$ Secondly, it will also depend on the willingness and ability to genuinely prosecute and investigate crimes within the jurisdiction of the Court. This implies that where there are on-going investigations and prosecutions, then the case must be inadmissible. However, where the Court establishes unwillingness or inability in terms of the Statute, then the case must be admissible. Therefore, the activities of a state in relation to prosecution or investigation will prompt the determination of whether a state is either willing or unable. That a case is admissible before the Court is therefore a presumed fact that can be rebutted by the activities of a state regarding its investigations and prosecution of the concerned case. ${ }^{36}$ Finally, a case is deemed inadmissible if it is not of sufficient gravity.

\subsubsection{The question of unwillingness and inability}

Although the Statute does not define these concepts, it establishes a criteria of establishing whether a state is 'unwilling'; if the proceedings (against alleged perpetrators of international crimes)

were or are being conducted or a national decision was made for the purpose of shielding the person concerned from criminal responsibility; or there are unjustified delays or the proceedings were or are not being conducted independently and impartially in a manner inconsistent with the intent to bring the person concerned to justice. ${ }^{37}$

This provision underlies the concept of complementarity by ensuring that the ICC does not interfere with the national investigations or prosecutions except in the most obvious cases. ${ }^{38}$

However, the difficulty inherent in establishing that a state undertook investigation or made a decision for the purpose of shielding the perpetrators from justice cannot be downplayed. In practice, the court is likely to create and rely on a presumption of unwillingness where the investigations or prosecution of some

\footnotetext{
34 ICC Appeals Chamber, Prosecutor v Katanga and others, Judgment on the Appeal of Mr Germain Katanga against the Oral Decision of Trial Chamber II of 12 June 2009 on the Admissibility of the Case (25 September 2009) ICC-01/04-01/07-1497.

35 Kai Ambos, The Colombian peace process and the principle of complementarity of the International Criminal Court, (Springer 2010) 59. According to Ambos, the Statute - art 17(1)a, b and c together with 20(3) adopts an exhaustive approach that covers all procedural stages from investigations to court trials.

${ }^{36} \mathrm{Kai}$ Ambos (n 34) 54.

${ }^{37}$ Rome Statute, art 17(2)a.

${ }^{38} \mathrm{John}$ T Holmes, 'Complementarity: national courts versus the ICC', in Antonio Cassese and others (eds), The Rome Statute of the International Criminal Court: a commentary (Oxford University Press 2002) 675.
} 
perpetrators led to 'sham proceedings'. ${ }^{39}$ Holmes enumerates a list of other factors that the court is likely to rely on when determining the intent of a state to shield the accused from international investigation and prosecution: obvious departures from normal legal procedures of a state for instance, bypassing the normal criminal procedures (whether civil or military) by appointing a special investigator who is politically aligned with persons close to the accused; transfer of cases to secret tribunals; moreover, article 17(2) of the Rome Statute obligates states in making its determination 'to have regard to principles of due process as recognized by international law'. ${ }^{40}$ This would imply that the court is likely to interpret any practice by a state that is inconsistent with established principles of international law as having been undertaken with the intent to shield the accused from justice. Other scholars have also interpreted the term 'unwillingness' to simply mean 'sham trials' or 'sham investigations'. ${ }^{41}$ According to Ambos, 'the purpose' in the first part of the paragraph denotes the 'state's specific intention or desire to protect the individuals responsible. ${ }^{42} \mathrm{He}$ further underscores the need for bad faith as a constituent factor of the state's intention not to bring the persons to justice which bad faith can only be inferred from circumstantial evidence. The circumstantial evidence suggested by Ambos closely resembles those suggested by Holmes. ${ }^{43}$

Regarding the second criteria, a distinction has been drawn between justified delay' and 'undue delay'. ${ }^{44}$ While the former gives room for justified delay, the latter does not. However, when considering such justification, due regard must be paid to the principles of human rights, the complexity of the case, conduct of the parties, the length of ordinary criminal proceedings et cetera. ${ }^{45}$ Thus, not all justifications are plausible, particularly those contrary to the objective of article 17 - to bring the suspects to justice.

With respect to independence and impartiality of proceedings, the ICC must be satisfied not only of doubts concerning the impartiality and independence of the proceedings but that this doubts led the Court to believe that the proceedings are conducted in a manner inconsistent with bringing the accused to justice. ${ }^{46}$ Independence has been associated with external influence or pressure on tribunals and

\footnotetext{
39 Ibid.

40 Ibid.

41 Julio Bacio Terracino, 'National implementation of ICC crimes: Impacts of national jurisdictions and ICC' (2007) 5(2) Journal of International Criminal Justice 421, 440.

${ }^{42} \mathrm{Kai}$ Ambos (n 35) 66, referring to Mohamed El Zeidy, The Principle of Complementarity in International Criminal Law: Origin, Development and Practice (Martinus Nijhoff Publishers 2008) 135.

43 Ibid.

${ }^{44}$ Kai Ambos (n 35) 68 referring to Holmes, in Roy S Lee (ed), The International Criminal Court: The Making of the Rome Statute - issues, negotiations, results (Kluwer Law International 1999) 41, El Zeidy (n 41) 181, Jo Stigen, The Relationship between the International Criminal Court and National Jurisdictions: The Principle of Complementarity (Martinus Nijhoff 2008) 289.

45 Ibid.

46 John T Holmes (n 38) 676.
} 
their proceedings. ${ }^{47}$ Impartiality, on the other hand, has been associated with possible bias of the tribunal's personnel. ${ }^{48}$ Noting the overlap among the 3 aspects embodied in the criteria, Holmes, acknowledges the similarities of the factors that would assist the court in determining whether a trial is conducted with the aim of shielding the accused from criminal prosecution to those that are used in determining that proceedings were undertaken with the aim of shielding a person from justice. ${ }^{49}$ Consequently, similar factors will lead to a conclusion that the trials were conducted in a manner to shield the perpetrators from criminal justice and that the same were conducted in a manner inconsistent to bringing the person to justice. Therefore, to prove 'unwillingness', one has to provide indicators of the intent by the state to shield the persons concerned from liability or the lack of independence of these trials.

Unlike unwillingness, determination of whether a state is unable is a more objective approach hence less problematic. The absence of a functioning prosecutor's office or a court system is a fact which either exists or does not. Nevertheless, the Rome Statute establishes a specific criterion of determining inability as follows: 'the court considers whether, due to a total or substantial collapse or unavailability of its national judicial system, the State is unable to obtain the accused or the necessary evidence and testimony or otherwise unable to carry out its proceedings. 50 This criterion is essentially a determination of facts some of which need no further interpretation.

Literally, a total collapse would refer to a judicial system that no longer works. On the other hand, a substantial collapse has been interpreted to be a judicial system that is 'damaged to an extent that is generally not capable anymore of ensuring the investigation of the case and the prosecution of individuals. ${ }^{51}$ According to some scholars, the notion of a 'total collaps' or 'substantial collapse' were purposely included in the Rome Statute with the rationale of precluding the Court from assuming jurisdiction merely because a conflict exists in a State and the judicial system is partially affected. ${ }^{52}$ This underscores the primacy of national criminal proceedings thus upholding the concept of complementarity. Unavailability can also be accorded the broadest literal meaning to mean: 'the non-existence of something, the nonaccessibility of something, and the non-usefulness of a remedy irrespective of its existence and accessibility. ${ }^{53}$

\footnotetext{
47 Kai Ambos (n 35) 69.

48 Ibid.

${ }^{49}$ John T Holmes (n 38) 676.

50 Rome Statute, art 7(3).

${ }^{51}$ Kai Ambos (n 35) 81 referring to Markus Benzing, 'The Complementarity Regime of the International Criminal Court: International Criminal Justice between State Sovereignty and the Fight against Impunity' (2003) 7 Max Planck Yearbook of United Nations Law 614; Stigen (n 44$) 316$.

52 John T Holmes (n 38) 676.

${ }^{53}$ Kai Ambos (n 35).
} 
It has been the Court's position that the question of unwillingness or inability is to be considered only

(1) when there are, at the time of the proceedings in respect of an admissibility challenge, domestic investigations or prosecutions that could render the case inadmissible before the Court, or (2) when there have been such investigations and the State having jurisdiction has decided not to prosecute the person concerned. ${ }^{54}$

Only when the two questions are in the affirmative would the Court proceed to determine whether the question of unwillingness and inability arise. ${ }^{55}$

While acknowledging that 'unwillingness under article 17(2) of the statute is motivated by the desire to obstruct justice', the Court has since entrenched 'a second form of unwillingness not expressly provided for under the Statute'. ${ }^{56}$ With respect to the latter, the Court has observed that it aims to see the persons brought to justice but not before national courts. ${ }^{57}$ The Court has further approved such an interpretation as being in line with the principle of complementarity. ${ }^{58}$ Related to this, are views that the principle of complementarity can 'neither be applied to force national proceedings, nor can it be applied to effectively perpetuate impunity'. ${ }^{59}$ Such an interpretation underscores the spirit of the Rome Statute 'to put an end to impunity' 60 and to ensure that 'most serious crimes of concern to the international community as a whole must not go unpunished and that their effective prosecution must be ensured by taking measures at the national level and by enhancing international cooperation'. ${ }^{61}$

In the event there are on-going investigations or prosecutions, the Court has underscored the need to apply same conduct-same person test. It has thus observed:

When, as in the present case, the existence of national proceedings is the sole reason for a possible finding of inadmissibility, it is a condition sine qua non for such a finding that national proceedings encompass both the person and the conduct which is the subject of the case before the Court. ${ }^{62}$

\footnotetext{
54 ICC Appeals Chamber, Katanga and others (n 34) para 78.

55 Ibid para 78.

${ }^{56}$ ICC Appeals Chamber, Katanga and others (n 34) para 59.

57 Ibid.

58 Ibid.

${ }^{59}$ Ibid para 67.

${ }^{60}$ Rome Statute, preamble, para 5.

${ }^{61}$ Ibid para 4.

${ }^{62}$ ICC Appeals Chamber, Katanga and others (n 34) para 20; see also ICC Pre-Trial Chamber I, DRC (n 29) para 38. See also ICC Pre-Trial Chamber I, Prosecutor v Abmad Mohammad Harun and Ali Mubhamad Ali Abd-Al-Rabman, Decision on the prosecution application under article 58 (7) of the Statute 27 April 2007) ICC-02/05-01/07, para 24.
} 
The mere existence of domestic investigations and prosecutions do not necessarily render a case inadmissible before the Court. For the case to be declared in admissible, it must refer to the same accused persons with respect to the same conduct under investigations. The same conduct test, writes Ambos, 'follows from the interplay of article 17(1)c and 20(3)'63 and should 'be understood strictly as incidentspecific' ${ }^{64}$ This is the underlying spirit of the principle of ne bis in idem as enshrined under article 20 of the Statute.

\subsubsection{Admissibility on the basis of inaction}

On the other hand, inaction of the state in relation to crimes of international concern is an abuse of the principle of complementarity which underscores the 'primacy of national criminal jurisdictions'. ${ }^{65}$ Thus, the Court has been of the view that inaction (where the state has not or is not investigating or prosecuting) on the part of a state that has jurisdiction renders a case admissible. ${ }^{66}$ In such a situation, the question of unwillingness and inability do not arise. ${ }^{67}$ It is worth noting that the total inaction of a state is considered as at the time of the determination of admissibility. Thus, possible future actions of investigations or prosecutions do not suffice to negate the inaction of a state. ${ }^{68}$

\subsubsection{The gravity test}

Gravity as a final test of admissibility is a mandatory requirement right from the time when investigations are initiated into a situation. ${ }^{69}$ Only when a case is of sufficient gravity will the complementarity test become relevant. ${ }^{70}$ Unfortunately, the issue of gravity remain shrouded in the uncertainty over the criteria for its determination. In an attempt to remedy this situation, the PTC adopted the following criteria in determining sufficient gravity: the conduct must be large scale or systemic and it must have raised a social alarm in the international community. ${ }^{71}$ According to the PTC, the intention of the additional gravity test is to ensure that 'the Court initiates cases only against the most senior leaders suspected of being

\footnotetext{
${ }^{63}$ Kai Ambos (n 34) 40 referring to Rod Rastan, "What is a "case" for the purpose of the Rome Statute?'(2008) 19 Criminal Law Forum 437.

${ }^{64}$ Ibid.

${ }^{65}$ See (n 23) and (n 24).

${ }^{66}$ ICC Appeals Chamber, Katanga and others (n 34) para 78.

${ }^{67}$ Ibid para 79.

${ }^{68}$ ICC Pre-Trial Chamber II, Kony and others (n 27) para 52. The Pre-Trial Chamber II confirmed the admissibility of the case against Kony and others because of 'total inaction' on the part of the Ugandan government even though there were plans for the future establishment of a Special Division of the Ugandan High Court to prosecute the case. This decision was upheld by the appeals chamber.

${ }^{69}$ ICC Pre-Trial Chamber I, DRC (n 29) para 45.

70 Ibid.

${ }^{71}$ Ibid para 47.
} 
the most responsible for the crimes [...] under investigations. ${ }^{72}$ Thus the Court would be concerned with the position of such individuals, the roles they play and the role played by such state entities and organizations or armed groups in the commission of the crimes. ${ }^{73}$ This interpretation has since been criticized and rejected by the Appeal Chambers ${ }^{74}$ even though the chamber shied from proposing concrete criteria of determining the same. Some scholars have considered gravity at two levels: legal gravity pursuant to article 53(1)(b), 17(1)(d) and relative gravity pursuant to article $53(1)$ (c).${ }^{75}$ While the latter refers to the prosecutors discretion in determining certain aspects like 'the interests of victims' under article 53(1)c, the former is concerned with the Court's determination of admissibility within the legal confines created by Statute. ${ }^{76}$

\subsection{Analysis of the Kenyan experience}

Kenya supplies a most intricate situation. First, there had been several failed attempts in Parliament at passing a law to enable the establishment of a Special Tribunal to try the suspects of post-election violence. ${ }^{77}$ At this point, both the public and a majority of the politicians chanted 'the ICC'. ${ }^{78}$ Perhaps, to the political class, the ICC seemed to be impracticable - something that was close to impossible. ${ }^{79}$ To the public, however, the ICC offered the only viable solution given the history of a deep-rooted culture of impunity. ${ }^{80}$ When the ICC became a reality, the government rushed to seek for an extension of time for the establishment of a local tribunal. ${ }^{81}$ These efforts to have a local tribunal were later thwarted by the cabinet upon its refusal to settle for an independently appointed tribunal. ${ }^{82}$ The members of parlia-

\footnotetext{
72 Ibid para 51.

73 Ibid para 52-53.

74 ICC Appeals Chamber, Situation in the Democratic Republic of Congo, Judgment on the prosecutor's appeal against the decision of the Pre-Trial Chamber I 'Decision on the Prosecutors application for warrants of arrest, article 58' (13 July 2006) ICC-01-04-169.

75 Kai Ambos (n 34) 48, referring to Ignaz Stegmiller, 'The Gravity Threshold under the ICC Statute: Gravity Back and Forth in Lubanga and Ntaganda' (2009) 9 International Criminal Law Review 561.

76 Ibid.

77 On 12 February 2009, a ‘Constitution of Kenya (Amendment Bill) 2009' allowing the creation of a local tribunal was shot down.

78 'It's The Hague, Kenyans tell violence suspects' Daily Nation (Nairobi, 19 July 2009) 8 and 9. See also 'Hopes for justice high among Kenyans as Ocampo arrives' Daily Nation (Nairobi, 6 November 2009) 4. Pursuant to 'MPs vow to defy Kibaki and Raila' The Standard (Nairobi, 7 July 2009) <http:/ / www.standardmedia.co.ke/ incl=comments\&id=1144018708\&cid=\&articleID=114401870 $8>$ accessed 3 July 2012, the Members of Parliament vowed to block the Bill seeking to try post-poll offenders locally for fear of manipulation from the executive.

79 'Tough call for election chaos suspects after ICC gag order' The Standard (Nairobi, 31 August 2009) <http://www.standardmedia.co.ke/ $\mathrm{id}=2000044915 \& \mathrm{cid}=4 \&$ articleID=2000044915> accessed 3 July 2012.

80 'It's The Hague, Kenyans tell violence suspects' Daily Nation (Nairobi, 19 July 2009) 8 and 9.

81 'Delayed justice' Kenya Times (Nairobi, 5 July 2009) 6.

82 'The cabinet rejects draft laws on local tribunal' Daily Nation (Nairobi, 15 July 2009) 1.
} 
ment insisted on a local tribunal headed by local judges. ${ }^{83}$ Such a move could only be read with disdain as the Kenyan public warned against protection of selfish interests. ${ }^{84}$ This stalemate on prosecution prompted the prosecutor of the ICC to file a request for authorization of an investigation into the situation in Kenya in accordance with article 15 of the Rome Statute. Which request was duly granted on 26 November 2009.

Second, before the ICC investigations were launched against six individuals, William SamoeiArapRuto, ${ }^{85}$ Henry Kiprono Kosgey, ${ }^{86}$ Joshua Arap Sang, ${ }^{87}$ Francis Kirimi Muthaura, ${ }^{88}$ Uhuru Muigai Kenyatta ${ }^{89}$ and Mohammed Hussein Ali $^{90}$ (the 'Ocampo six') - there had been no legal action or any state investigations of the six under local mechanisms. Interestingly, during the ICC investigations, the Kenyan government not only ordered the police to commence investigations of the crimes committed during the 2007 post-election violence ${ }^{91}$ but also made an application to the Pre-Trial Chamber of the ICC challenging the admissibility of the cases against the six. ${ }^{92}$

The seizure of the Kenyan situation by the ICC has provoked debate on numerous issues. Some of these include: whether the Kenyan situation met the required threshold under the Rome Statute? Whether the government of Kenya was ready to hand over its very own for a prosecution process before the ICC? Whether the Kenyan government understood its obligation under the Rome Statute and the International Crimes Act? Perhaps answering these questions would assist an in-depth understanding of Kenya's conduct towards admissibility of the situation before the Court. Thus, appreciating the various dynamics through which the principle of complementarity has been tested.

\subsection{Admissibility in the Kenyan context}

When challenging the admissibility of the Kenyan cases before the ICC, the government of Kenya called the attention of the Court to the current constitutional and judicial reforms which arguably, enabled Kenya to deal with the cases before

\footnotetext{
83 Parliament of the Republic of Kenya, 'National Assembly Official Report' Plenary Hansard (22 December 2008) p. 83

<http://www.parliament.go.ke/index.php?option=com_content\&view $=$ article\&id=91\&Itemid=84> accessed 14 July 2011. The Kenyan parliament passes motion to withdraw from the ICC.

84 'Don't weaken the tribunal to help special interests' The Standard (Nairobi, 23 January 2009$) 4$.

85 Suspended Minister of Education.

${ }^{86}$ Formerly Minister for Transport and Communications.

87 Journalist with Kass FM Radio.

${ }^{88}$ Head of Public Service Commission and Secretary to the Cabinet of Kenya.

${ }^{89}$ Deputy Prime Minister and Minister of Finance.

${ }^{90}$ Formerly Police Commissioner, but currently Chief Executive Officer of the Postal Corporation of Kenya.

91 The police were ordered to commence investigations in April 2011.

92 This application was made on 31 March 2011.
} 
the ICC without necessarily enacting a special law establishing a special tribunal. ${ }^{93}$ Further, the government emphasized the fact that it had ordered investigations into the crimes arising out of the 2007 post-election violence. ${ }^{94}$ As such, there were on-going national investigations which barred the ICC from admitting the situation under its admissibility procedure. According to the Kenyan government, these two reasons were adequate to have the ICC declare the case inadmissible.

While interpreting the Rome Statute, the Court observed that the admissibility test is at two levels: the complementarity level which embodies section 17(1)(a)-(c) and the gravity level - 17(1)(d). ${ }^{95}$ Regarding complementarity, the ICC underscored the fact that the Court is normally concerned with 'the existence or absence of national proceedings'. ${ }^{96}$ The Court ordinarily asks itself the following two questions:

1. Are there on-going investigations or prosecution?

2. Have there been investigations and the State with jurisdiction has declined to prosecute?

In the event these questions are answered in the negative, then the case becomes admissible and one need not to move the test further to either unwillingness or inability. ${ }^{97}$ Conversely, where the two questions are answered in the affirmative, only then is there a need to move the test further and determine whether there was unwillingness or inability on the part of the state in order to render the case admissible.

According to the Court, even though the Kenyan government claimed that there were on-going investigations, these were too hypothetical promises and not investigations within the context of article 17(1)(a). ${ }^{98}$ Having written to the Police Commissioner to institute investigations into the post-election violence suspects two weeks after lodging the application challenging admissibility ${ }^{99}$ in which it was alleged that there were ongoing investigations, coupled with the failure to specifically mention the suspects before the ICC as some of the people under the gov-

\footnotetext{
${ }_{93}$ ICC Pre-Trial Chamber, Prosecutor v Francis Kirimi Muthaura, Uburu Muigai Kenyatta and Mohammed Hussein Ali, Decision on the Application by the Government of Kenya Challenging the Admissibility of the Case Pursuant to Article (19)(2)(b) of the Statute, (30 May 2011)ICC-01/09-02/11-96, 6. ${ }^{94}$ Ibid.

95 Ibid 17. See also ICC Pre-Trial Chamber II, Prosecutor v William Samoei Ruto, Henry Kiprono Kosgey and Joshua Arap Sang, Decision on the Application by the Government of Kenya Challenging the Admissibility of the Case Pursuant to Article 19(2)(b) of the Statute (30 May 2011) ICC-01/09-01/11-101, 19.

96 ICC Pre-Trial Chamber II, Muthaura, Kenyatta, Ali (n 93) 18. See also ICC Pre-Trial Chamber II, Ruto, Kosgey, Sang (n 95) 19.

${ }_{97}$ ICC Pre-Trial Chamber II, Ruto, Kosgey, Sang (n 95) 20 referring to ICC Appeals Chamber, Katanga and others (n 34) para. 78; see also ICC Pre-Trial Chamber II, Muthaura, Kenyatta, Ali (n 93) 18.

${ }_{98}$ ICC Pre-Trial Chamber II, Muthaura, Kenyatta, Ali (n 93) 10; see also ICC Pre-Trial Chamber II, Ruto, Kosgey, Sang (n 95).

${ }^{99}$ Ibid.
} 
ernment's investigation, ${ }^{100}$ rendered the information given by the Kenyan government inadequate to sustain the application. The Court was emphatic that an investigation within the meaning of section 17(1) must encompass the same conduct in respect of the same persons as at the time of the proceedings concerning the admissibility challenge. ${ }^{101}$ This was contrary to the submissions made by the government of Kenya that the 'national investigations must [...] cover the same conduct in respect of persons at the same level in the hierarchy being investigated by the ICC.'102

Besides, the said on-going investigations in Kenya were with respect to all crimes committed during the 2007 post election violence. As such, the Court was uncertain as to whether the investigations involved the same persons and crimes being investigated by the ICC. ${ }^{103}$ In fact, the request by the government of Kenya to the Police Commissioner to institute investigations two weeks after filing the application on admissibility meant that there were no such investigations as at the time of the proceedings. Thus, the Court considered the Kenyan situation admissible.

This jurisprudence serves two critical purposes. First, it portrays the extent to which states do not understand the principle of complementarity as embodied in the Rome Statute. This explains the numerous inconsistencies in Kenya's conducts towards its obligation under the Statute. Secondly, it supplies essential lessons to states and scholars on the interpretation of the Statute.

\section{The ICC factor on Prosecution as a transitional justice mechanism in Kenya}

As earlier mentioned, following numerous failed attempts at securing a local mechanism to undertake prosecution of those who are considered to bear the greatest responsibility for the post - election violence of 2007, the ICC seized the Kenyan situation. This was through the ICC prosecutor exercising his 'proprio motu powers'. 104 Thus, the prosecutor of the ICC opened investigations against the 'Ocampo six'.

Even though the Act provided a legal basis for Kenya to undertake a trial process of the suspects who bore the greatest responsibility for the alleged international crimes, in practice, this seems to have been an uphill task for the government. Perhaps this can be attributed to the volatile ethnocentric nature of Kenyan

\footnotetext{
100 ICC Pre-Trial Chamber II, Muthaura, Kenyatta, Ali (n 93) 25; see also ICC Pre-Trial Chamber II, Ruto, Kosgey, Sang (n 95).

${ }^{101}$ ICC Pre-Trial Chamber II, Muthaura, Kenyatta, Hussein Ali (n 93) 21 and 26.

102 ICC Pre-Trial Chamber II, Muthaura, Kenyatta, Ali (n 93) 7 and 19; see also ICC Pre-Trial Chamber

II, Ruto, Kosgey, Sang (n 95) 8 and 21.

103 Ibid.

${ }^{104}$ Rome Statute, art.15(1).
} 
politics. On the one hand, the government may have feared being perceived as targeting certain communities. ${ }^{105}$

On the other hand, this would have been equivalent to subjecting the very government to self-ridicule since a majority of those under the ICC investigations occupy central positions within the Kenyan political class and most governance decisions revolve around them. Thus, it is uncertain whether the government would have competently subjected the same set of individuals to local prosecution. In fact, the vigour with which the government is fighting the ICC process confirms this. The prosecutor of the ICC has also lamented that the government of Kenya was thwarting investigations efforts of the post-election violence by the ICC. ${ }^{106}$ In addition, the refusal by the Kenyan government to arrest Omar Al-Bashir when he visited the country on 27 August 2010 coupled with the vitality with which the government has fought a Kenyan High Court decision ${ }^{107}$ calling upon it to effect the arrest of Mr. Al-Bashir in future whenever he makes such visits is evidence enough of how difficult it is for Kenya to adhere to its obligations under the Statute. The author opines that this is sufficient evidence that the government of Kenya would never have subjected the 'Ocampo six' to prosecution and that any attempts towards these ends would have amounted to 'sham trials'- perhaps to keep the ICC at bay.

Nonetheless, the choice of the six by the ICC has faced lots of criticisms both locally and internationally. This is particularly so on two fronts. Firstly, the evolving prosecutorial strategy has been criticised for excluding the wielders of power. For instance, the Kenyan public has largely felt that the two principles should be under the ICC investigations for having given orders. ${ }^{108}$ Similarly, other critics have felt that Mr. Odinga, the leader of the ODM party should have been held responsible for calling for mass action. ${ }^{109}$ While some of these critics are, in the most part, misinformed on the law, the fact that the prosecutor attempts to evade the real flag bearers cannot be wished away.

Secondly, the office of the prosecutor seems to have fallen victim to African politics. In the Kenyan situation for instance, the prosecutor has been criticised for

\footnotetext{
${ }^{105}$ Indeed once the names of those under the ICC investigations were released, the Kalenjin community complained of being targeted by political rivals. There was no other interpretation for 3 three Kalenjin men being put under the ICC investigations other than community sabotage.

106 'Ocampo accuses Kenya of blocking inquiry on chaos' Daily Nation (Nairobi, 30 May 2011) 6. See also ICC Office of the Prosecutor, 'Statement of the Prosecutor on the Situation in Kenya' (29 May 2011) 2 <http://www.icc-cpi.int/NR/rdonlyres/269744E4-9F7D-468F-9B24-

C2AE74B012D1/283377/StatementICCProsecutoronsituationinKenya1.pdf $>$ accessed 28 June 2012, in which Mr. Ocampo asked the government of Kenya whether it was protecting the victims or the suspects from investigations.

107 The Kenya Section of the International Commission of Jurists v. the Attorney General, The Minister of State for Provincial Administration and Internal Security, Final Judgment, [2011] eKLR; 28 November 2011.

108 'Go for Kibaki and Raila, lawmaker tells ICC' Daily Nation (Nairobi, 15 July 2009) 34.

109 'Blame game begins' Kenya Times (Nairobi, 12 July 2009) 1. A section of leaders from the Rift Valley call on Raila to take responsibility claiming that the bloodshed in the Province was on his behalf.
} 
playing along the party politics by ensuring that he investigates an equal number of persons from both political parties. Questions have been asked as to why the prosecutor could investigate only $3 \mathrm{ODM}$ and $3 \mathrm{PNU}$ individuals if not for political influence. ${ }^{110}$ Thus, the implementation of the Act not only poses a challenge to the government but it is also the source of tension-prone relationship between the ongoing ICC process and the government of Kenya. Nevertheless, that the ICC is positively influencing prosecution initiatives by ensuring an end to the long reigning culture of impunity is a fact that cannot be overemphasized.

\section{The ICC factor on Truth and Reparation Mechanisms}

Having been established in July 2009, the TJRC remained un-operational until January 2010 when it flagged off its awareness campaigns. ${ }^{111}$ The popularity that the TJRC had gained overtime soon waned following public accusations that the mechanism was itself an embodiment of impunity. ${ }^{112}$ Some of its commissioners were singled out to be the very people who had served in previous regimes that perpetrated horrendous abuses of human rights. ${ }^{113}$ In some instances, there were allegations that some of them were part of the alleged perpetrators of past atrocities and thus would be compelled to appear before the Commission as witnesses. ${ }^{114}$ This would therefore lead to a conflict of interest and thus compromise the independence, as well as, the general operation of the Commission.

Calls for the disbandment of the TJRC became the order of the day. ${ }^{115}$ At the height of the moment, the commission was heckled in some of its gatherings by

110 Muwiri Mutuota 'Ocampo: I am not playing politics' Capital News (11 April 2011) <http://www.capitalfm.co.ke/news/2011/04/ocampo-i-am-not-playing-politics/> accessed 26 June 2012.

111 The author was privileged to be a consulting researcher/rapportuer with the TJRC Kenya during this time.

112 Bunge La Mwananchi Secretariat, 'Case against the TJRC', Bunge la Wananchi (16 October 2011) $<$ http:/ / www.bungelamwananchi.org/index.php?option $=$ com_content\&view $=$ article\&id $=406 \% 3 \mathrm{Aa}$ uctor-et-sed-at-sodales\&Itemid $=27 \&$ catid $=82 \% 3 \mathrm{~A}>$ accessed 28 June 2012.

113 Ambassador Bethuel Kiplagat, the then Chairman of the Commission, had served as the Permanent Secretary in the Ministry of Foreign Affairs during the former President Daniel Arap Moi's regime which regime has been accused of horrendous human rights abuses.

${ }_{114}$ Njeri Kabeberi, Ndung'u Wainaina and Cyprian Nyamwamu 'Our lords of impunity stand to gain from a Kiplagat-led TJRC' Daily Nation (1 April 2010)

<http://allafrica.com/stories/201004010990.html> accessed 27 June 2012.

115 Judie Kaberia, 'Kenya TJRC now faces dissolution' Capital News (Nairobi, 14 April 2010) $<$ http://www.capitalfm.co.ke/news/Kenyanews/Kenya-TJRC-now-faces-

dissolution.html\#ixzz1QmU8TVsd accessed 30 June 2012> accessed 28 June 2012. The then minister for Justice, National Cohesion and Constitutional Affairs called upon the Parliamentary Committee on Legal Affairs to formulate modalities of disbanding the Commission; see also two cases that were filed in court seeking the disbandment of the commission: Augustine Njeru Kathangu and 9 others $v$ TJRC and Betbuel Kiplagat, High Court Miscellaneous Application No. 470 of 2009. See also Moraa 
rowdy audience who demanded the suitability of the Chairman of the Commission. ${ }^{116}$ Eventually, the then vice chairperson of the commission resigned in protest. Meanwhile, the government ruled out any possibility of extending the time period of the Commission. ${ }^{117}$ This resulted into the Civil Society Organizations, the political class and some donor communities distancing themselves from the process. ${ }^{118}$

Devoid of funds and political support, the TJRC stagnated for a year. It was not until September 2010 that the TJRC substantively embarked on the execution of its mandate.119 Given the long-standing stalemate, one wonders whether the Commission will effectively achieve its mandate within the remaining time period (of approximately six months as at the time of this writing).

It is further instructive to note that on 1 November 2010, a tribunal was subsequently formed to investigate into the conduct of the chairman of the Commission during his tenure as the Permanent Secretary in the Ministry of Foreign Affairs during the former president Daniel Arap Moi's regime. Following this development, the chairman stepped aside to allow investigations on his conduct with respect to past abuses. As at the time of this article, the Tribunal had stalled following an order by the High Court staying its proceedings until an application by the said chairman is determined. Meanwhile, the TJRC has continued dispensing its mandate and the former chairman has since witnessed before it. ${ }^{120}$

Given the numerous challenges facing the TJRC, a bet as to whether its outcome is going to have any national impact has proven to be a tricky one. Even though, legally speaking, there is a difference between the retributive nature of prosecutions and the restorative nature of truth commissions, this distinction has failed to exist among the Kenyan locals. The public seems to have been disillusioned by the TJRC process as all eyes focus on the unfolding ICC prosecutions. Besides, the ongoing ICC process seems to be negatively affecting the TJRC in realizing its objectives. One notable shortcoming of the TJRC is that so far, none of all those people who have attended and taken part in their public hearings have confessed to be the perpetrators of past atrocities. Despite statutory guarantees of confidentiality of witness evidence, ${ }^{121}$ both the perpetrators and those who possess vital information about past atrocities, particularly the 2007 violence have shied away from the process for different reasons. While the perpetrators fear their word being used against them in the ICC, the vital witnesses dread the probable conse-

Gesicho v Attorney General and TJRC, High Court Petition No. 1 of 2010 - Kisii. Both cases are still pending in court.

116 Kenya, TJRC Research Unit, Rapporteurs Report on Coast Province (2010) (unpublished document): some of the challenges faced by the TJRC as hostility from the CSOs in Mombasa and Lamu.

117 Francis Mureithi 'TJRC doesn't deserve more time' All Africa News (5 March 2011) <http://allafrica.com/stories/201103070178.html> accessed 27 June 2012.

118 TJRC, Progress Report to the National Assembly (2011) 43 (unpublished document).

119 See generally, TJRC, Progress Report to the National Assembly (2011) 43 (unpublished document).

120 This happened on 6 May 2011.

121 TJR Act 2008, s 24(3). 
quences of their acts since those suspected to possess such knowledge have, in earlier instances, alleged to have either lost their lives under mysterious circumstances or had their lives threatened. ${ }^{122}$ This happens despite the existence of statutory guarantees on confidentiality of such information.

The fear that has been instilled in the perpetrators is well founded. Perhaps the Kenyan TRC, in its sunset days, may borrow a leaf from Sierra Leone's experience. At its formative stages, the TRC of Sierra Leone hardly considered its relationship with the Special Court of Sierra Leone (SCSL) with respect to the issue of selfincriminating evidence adduced before it. ${ }^{123}$ Following the concerns raised by the members of the public and some of the revolutionary forces involved in the war the Revolutionary United Front (RUF) - over the independence of the commission and its relationship with the SCSL, the TRC recognized the potential effect this may have in undermining its mandate. ${ }^{124}$ This necessitated the adoption of a firm position by the TRC over confidentiality of information received coupled with extensive outreach programs. ${ }^{125}$ This perhaps explains why a majority of the witnesses who testified in the TRC were victims and most of the perpetrators who testified lied. ${ }^{126}$ This confusion was, further, manifested in the later stages of the TRC when the SCSL refused its convicts to witness in TRC's public hearings. ${ }^{127}$

The essence of any TJRC process is multifaceted. Of great importance, any TRC process aims at establishing the 'full truth', reparations and reconciliation. ${ }^{128}$ To achieve these objectives, the role played by the perpetrators or the wrongdoers

122 Murithi Mutiga, 'Ocampo writes to judges over threats' Daily Nation (Nairobi, 31 January 2010) $<$ http://www.nation.co.ke/News/-/1056/852780/-/vpwpw9/-/index.html> accessed 27 June 2012. Witnesses with crucial evidence against suspected masterminds of Kenya's post-election violence allege to threats. See also, 'Witnesses at risk, warns lobby group' Daily Nation (Nairobi, 11 January 2010) <http://www.nation.co.ke/News/politics/-/1064/840302/-/wsh1w6z/-/index.html> accessed 3 July 2012. The chairman of the Kenya National Commission on Human Rights (KNCHR) testifies, that 22 witnesses who testified before the CIPEV have been threatened.

123 William A Schabas, 'The Relationship between the truth commissions and international courts: the case of Sierra Leone' (2003) 25 HRQ 1049.

124 United Nations Security Council (UNSC), Eleventh Report of the Secretary-General on the United Nations Mission in Sierra Leone (7 September 2001) S/2001/857.

125 William A Schabas (n 123) 1050.

${ }^{126}$ See generally, Tim Kelsall, 'Truth, lies, rituals: preliminary reflections on the Truth and Reconciliation Commission in Sierra Leone' (2005) 27 HRQ 359-391.

127 Priscilla Hayner, Report on negotiating Peace in Sierra Leone: Confronting the justice Challenge (Henry Dunant Center and others 2007) 28. See also SCSL, Prosecutor v Norman, Decision on the Request by the TRC of Sierra Leone to Conduct a Public Hearing with the Accused (29 October 2003) SCSL-03-08PT-101. In denying this application, Judge Bankole Thompson found that it was not in the interest of justice to grant Sam Hinga Norman for the TRC's public hearing. Given that the TRC had classified Hinga as a perpetrator, by the court agreeing to the hearing, it may be seen as acquiescing to that classification hence violating the presumption of innocence and fair trial. On Appeal to the Appeals Chamber, Judge Robertson upheld the decision of the Trial Chamber for reasons, inter alia, that the accused would use the public hearings as a political platform which would have a detrimental effect to the integrity of his trial.

128 Makau Mutua (n 15) 9. See also Evelyne Asaala (n 12) 401, 406 in which the author documents the challenges of reparations, reconciliation and truth in the Kenyan context. 
cannot be underestimated. How then does a truth commission reconcile the victims alone? What about establishing 'full truth'? Is the Kenyan TJRC falling into similar criticisms like the South African TRC for establishing a 'diminished truth'?129 These are some of the most difficult parables that the Kenyan TJRC may never unravel. Besides, the reparation mandate of the TJRC seems to have been overtaken by events. Although the TJRC has got a statutory mandate to recommend reparations to the victims of past atrocities; ${ }^{130}$ the government has taken over the process without any guiding legal policy. It is still uncertain as to whether the government's approaches will auger well with the ICC's probable approach in the event the Court makes such orders. ${ }^{131}$

It is however notable that there is no existing practice yet by the ICC on reparations. Nonetheless, before a decision on reparation is made by the Court, the Trust Fund for Victims (TFV) comes in handy to assist the victims end their suffering. This happens immediately a situation has been seized by the ICC. The mandate allowing the TFV to spring into action is twofold: it can be based on the court order or a decision by the Board of Directors (BOD). Of notable concern is the fact that the board has not taken a position on Kenyan victims. Perhaps the magnitude of their suffering is less persuasive or maybe the BOD has left the matter to the Court.

\section{The ICC factor in the constitutional reform process}

In similar vein, the constitutional reform process has variously been impacted by the ICC factor. First and foremost, the journey in search for a new constitution had often been frustrated by compelling negative forces. The discourse on constitutional reform first came to the fore after the 1992 general elections following the re-introduction of a multi-party democracy. ${ }^{132}$ The opposition political parties, together with the Civil Society Organizations (CSOs) agitated for comprehensive constitutional reforms. However, these developments were shelved by the ruling party and only re-surfaced in 2001 when Parliament, through legislation ${ }^{133}$ established the Constitution of Kenya Review Commission (CKRC). Three months later, this process collapsed following fractional politics. ${ }^{134}$ At the height of the process, personal differences deteriorated to near physical fights as the chairman of

\footnotetext{
129 Mahmood Mamdani, 'A diminished truth' in Wilmot Godfrey James and Linda Van de Vijver (eds) After the TRC: Reflections on truth and reconciliation in south Africa (Ohio University Press, 2001) 58.

130 TJR Act 2008, s 41 and 42.

131 Rome Statute, art. 75: the ICC has got the mandate to make any appropriate orders as to reparation of victims.

${ }^{132}$ Chris Odhiambo-Mbai (n 22 above) 69.

133 Constitution of Kenya Review Commission (Amendment) Act 2001.

134 Joe Khamisi (n 17) 233.
} 
the Committee on devolution was assassinated. ${ }^{135}$ This process was devoid of the civil society group and the opposition party who became aggrieved and formed a parallel constitution reform process dubbed the Peoples' Commission of Kenya (PCK, popularly known as the 'Ufungamano Initiative'). In 2001, the Act was amended merging the two groups to form a panel of 27 commissioners.

In October 2002, the CKRC released its first draft constitution (the Bomas draft). Before this draft was tabled to parliament for approval, the then President Moi rushed to dissolve Parliament. ${ }^{136}$ Despite protests from the CSOs and the public, Moi went ahead to dissolve a National Constitutional Conference (NCC) that had been set to debate the final draft of the constitution before tabling it in Parliament. ${ }^{137}$ Having won the December 2002 general elections, the then opposition party (NARC) promised to deliver a constitution within 100 days. However, this path of constitution writing was, not going to be as easy as earlier on contemplated.

The search for a new constitution became even more tenuous since three months after its inauguration; the NARC government degenerated into politics of fragmentation.Efforts to reconvene the NCC were frustrated by the differences of the various segments that comprised the NARC factor. Eventually, the Bomas process came to naught. ${ }^{138} \mathrm{~A}$ draft constitution was later developed by a faction of the NARC government. This is the document that was widely rejected by Kenyans in a referendum held on the 21 November 2005. ${ }^{139}$ The question of constitutional review had thus been put to rest - though not for eternity.

The post election violence of 2007 therefore played an essential role in the constitutional reform process. The violence acted as a reminder to the country on the inevitable need of both institutional and constitutional reforms that were long overdue. Thus, to achieve these ends, the ICC element has been vital in arguably either eliminating or instilling fear in the would-be opposing forces against these reforms. The keen watchful eye of the international community - especially the seizure of the Kenyan situation by the ICC - must have cracked the whip at the right time. Besides, the government thought that the adoption of a new constitution, would tame the ICC process. Thus far, the ICC situation contributed to the birth of a new constitutional dispensation.

Secondly, at the implementation stage, a critical analysis of the unfolding process is inadequate without alluding to the ICC element. Soon after the promulga-

\footnotetext{
135 Ibid. According to Khamisi, the murder of Mbai became political when 'those arrested for the murder told the police they had been paid by a NARC politician to carry out the assassination.' The local media that published the story witnessed the arrest of its top leadership.

136 Maria Nzomo, 'Civil society in the Kenyan political transition: 1992-2002' in Oyugi, Wanyande and Odhiambo-Mbai (n 22) 195.

137 Ibid.

138 The preliminary report of the committee of experts on constitutional review issued on the publication of the harmonized draft constitution (2009) 12.

139 Ibid.
} 
tion of the constitution on 27 August 2010, the government seemed to have found a legal basis to retreat from the ICC route. On various occasions, the government referred to the new constitution as its new strength to try the six individuals. ${ }^{140}$ In this regard, several avenues were exploited in attempt to keep the ICC at bay. First, the government sought to lobby its allies on a deferral of the cases against the said six individuals. The vice president, Kalonzo Musyoka, engaged in shuttle diplomacy within the region and the United Nations seeking support on this particular issue. Underneath deferral, a critical mind would have read the politics of succession. A progressive interpretation of the new constitution would bar anyone with any pending case in a court of law against vying for any public office. ${ }^{141}$ Given that two of the 'Ocampo six' are presidential hopefuls of the next general elections of 2012, the government must have foreseen the technical hinge evident in its succession to the throne. However, none of these efforts, bore any fruits. The government discovered that the deferral idea was a non-starter.

Secondly, Kenyan Parliament later overwhelmingly voted in favour of a motion arguing that the government to withdraw from the Rome Statute. ${ }^{142}$ Realizing the limited impact this would have in the international arena, the government agreed to reach out to the region and other sympathisers seeking their consent in an en mass withdrawal from the ICC. Indeed, the African Union (AU) guaranteed its support for Kenya in the event of a withdrawal. This withdrawal was, however, misguided. In the most part, the government was under the illusion that such withdrawal would have compelled the ICC to back off the Kenyan cases. On the contrary, such a step had been overtaken by events since the process had begun way before the withdrawal. The prosecutor of the ICC criticised this move as being 'short sighted and unfortunate.' Perhaps it was the realization that such a move was not going to salvage the six that the government opted for another alternative.

Thirdly, on 31 March 2011, the government of Kenya lodged an application before the ICC challenging the admissibility of the Kenyan situation in accordance to article 19 of the Rome Statute. While submitting on its ability and willingness to takeover the prosecutions, the government of Kenya urged the ICC to take into account the comprehensive constitutional and judicial reforms that have been adopted. ${ }^{143}$ On 30 May 2011, the Pre-Trial chamber dismissed the challenge on admissibility. According to this Chamber, the government did not adduce infor-

\footnotetext{
140 'Mutula to Ocampo, quit Kenyan probe' Sunday Nation (Nairobi, 19 September 2010) 1. See also 'Why go to the Hague' Sunday Nation (Nairobi, 19 September 2010) 15. The then minister for justice and Constitutional Affairs called upon the ICC to quit the Kenyan probe and to allow Kenya a chance under the new constitutional Court structures to deal with the cases.

141 The Constitution of Kenya, Part IV.

${ }^{142}$ Parliament of the Republic of Kenya, 'National Assembly Official Report' Plenary Hansard (22

December 2010) p. 83

$<$ http:/ $/$ www.parliament.go.ke $/$ index.php?option $=$ com_content\&view $=$ article\&id $=91 \&$ Itemid $=84$ accessed 14 July 2011. The Kenyan parliament passes motion to withdraw from the ICC.

143 ICC Pre-Trial Chamber II, Muthaura, Kenyatta, Ali (n 93) 6.
} 
mation to substantiate the challenge. Thus, 'inaction' that warrants the case to be admissible.

Before delivery of the Court's ruling, the president quickly and single-handedly made three crucial appointments under the new constitution. He appointed an Attorney general, a chief justice and a Deputy Public Prosecutor. These appointments drew heavy criticism from the public perhaps on genuine grounds. First, the manner in which these appointments were made was said to contradict the very spirit of the National Accord -the agreement that brokered peace between PNU and ODM - which required all appointments to be made with the consent of both principals; the Prime Minister and the President. In this case, the Prime Minister claimed to have never been consulted on the issue. These appointments were further criticised on the ground that all the appointees were sympathetic to the status quo. ${ }^{144}$ Eventually, the president bowed to pressure and withdrew all the appointments. Whether the public suspicions were based on the correct hypothesis or not, one would also argue that the hurried appointments were an attempt to portray a reformed judiciary, thus a competent institution to try the six. Perhaps by so doing, the president thought that he would have convinced the ICC to decide otherwise.

If the government actions were well intentioned in this regard, one then wonders why the government should retract from its initial support of the ICC process and insist on a local tribunal long after the matter had already been taken over by the ICC? After all, a trial by the ICC would not only save government the burden of spending tax payers' money but also assure some level of impartiality and competence. In any case once justice is done and is seen to be done, it matters less where one is prosecuted. Thus, the birth of a new constitutional dispensation amidst the ICC process seemed to have introduced a new lease of life in the government's realization that it should try the six in a local tribunal.

As Kenya strives to transcend from its past to a just future, a few further questions call for considerations: does the Kenyan populace appreciates the on-going mechanisms in dispensing justice? To what extent has the ICC shaped the public perspectives on justice?

\section{The role of the ICC in shaping the local perspectives of justice}

From a legal point of view, transitional Justice for Kenya has been manifested as a holistic approach embodying socio, economic and political justice. Indeed, some scholars agree that transitional justice must exemplify all these elements. ${ }^{145}$ How-

\footnotetext{
144 'Kenyan judicial appointments null and void: PM' International Business Times (29 January 2011) $<$ http://www.ibtimes.com/articles/106599/20110129/kenyan-judicial-appointments-null-and-voidpm.htm> accessed 3 July 2012.

145 Teitel (n 15) 219; Fionnuala Ni Aolain and Colm Campbell, 'The paradox of transition in conflicted democracies' (2005) 27 HRQ 172; see also Makau Mutua (n 15) 9.
} 
ever, since the ICC seized the Kenyan situation, the local perspective on the meaning of transitional justice has gradually taken a bias tangent. Agreed that transitional justice is all inclusive - in all socio, economic and political spheres - and that there are several other on-going transitional justice initiatives, the ICC element seems to have diverted most of the public's attention from the other mechanisms. For example, even though the new constitutional order is a remarkable achievement under transitional justice, many Kenyans would readily relate any of its achievements to the ICC process. The ICC seems to occupy centre stage in the entire transitional justice process in Kenya. In turn, this has largely informed what the locals today perceive as justice to past atrocities. In common parlance, justice in Kenya is unparalleled to fighting impunity. This, in turn, implies prosecution of alleged perpetrators not just in Kenyan Courts but the ICC. Little wonder that while lamenting about illegal demolition of houses and corruption in the ministry of lands, one Member of Parliament erroneously alluded to the fact that what was happening was a crime punishable by the ICC in The Hague.

\section{Conclusion}

By ratifying and domesticating the Rome Statute, Kenya assumed a host of responsibilities with respect to prosecution of international crimes as embodied therein. However, it emerges that the Kenyan government neither comprehends the nature of these responsibilities nor the extent to which the same ought to be exercised. The manner in which the government of Kenya has conducted itself with respect to the principle of complementarity is of particular concern. This can only invite two conclusions; either the government did not understand its obligations under both the Act and the Rome Statute or that its actions were shrouded with malice. Nonetheless, this contribution serves as an eye opener on the interpretation of the principle of complementarity verses state obligations.

In addition, the ICC occupies centre stage in any discourse on transitional mechanisms in Kenya. Not only does it inform the on-going constitutional implementation process but also the TJRC and the prosecutions themselves. This influence is both at the social level, legal level and the political level. The author opines that on all fronts, the ICC has totally reshaped the manner in which the locals perceive justice. 



\title{
Implementing the Rome Statute in Africa: Potential and problems of the prosecution of gender crimes in Africa in accordance with the Rome Statute
}

\author{
Bonita Meyersfeld
}

\begin{abstract}
The key question for many international criminal law scholars is: to what extent are states parties properly implementing the Rome Statute? This is a question that is relevant to all regions but bolds particular fascination in Africa. This is so in part because all the situation cases before the International Criminal Court ('the Court') are in Africa. It is also because Africa as a region has the pernicious combination of poor rule of law, high rates of corruption, exploitation of natural resources and cheap labour and because Africa as a region has been beset with some of the worst conflicts since World War II ('WWII'), with some of the highest rates of violence globally.

Much of the analysis relating to the question of implementation focuses on the adoption of laws and procedures and the creation of a judicial infrastructure with independent and trained judges, prosecutors and defence lawyers.

One of the more difficult elements to examine, however, is the extent to which the provisions relating to gender in the Rome Statute are similarly implemented. This is a difficult question for a number of reasons. The first is because it is not immediately clear that the implementation of the Rome Statute in national systems requires a specifically gendered approach. While gender is most certainly an important feature in the operation of the Court and the applicable legal principles, the gender-specific principles are not necessarily incorporated into the domesticating legislation of state parties. This is exacerbated by the multifaceted understanding of 'gender'. In the context of international criminal law it is generally understood to comprise crimes that are committed against men or women because of their sex, in a manner that disproportionately affects women and in a context in which the sexual identity of an individual is ascribed certain cultural or social norms, rules or
\end{abstract}


expectations. There is also a question mark regarding the extent to which the ICC itself is adequately implementing its mandate in a gender-nuanced and sensitive manner. Finally, the lack of protection of women's rights in Africa is particularly acute.

The examination of gender protection is examined against the backdrop of an uncertain system at the international level, combined with an urgent and extreme need for protection at the national level. There are further complicating factors: international criminal law has only very recently identified gender-specific crimes (the history of which I discuss briefly below). Those crimes that have been identified relate exclusively to the sexual violation of women in conflict and there is a myriad of harm that is gender-specific, as I describe below, which is not yet categorised as criminal under either international or national legal systems.

In this article, I examine the development of gender-specific crimes in international criminal law, noting the important, yet narrow, enunciation of sexual crimes against women. I then consider the multiple ways in which women experience and are affected by conflict. Finally, I present a brief summary of some of the deficiencies in international criminal prosecutions and the way that these should be ameliorated both at the international and the national level.

\section{Mise en œuvre du Statut de Rome en Afrique: le po- tentiel et les problèmes de la poursuite judiciaire des crimes sexuels en Afrique, conformément au Statut de Rome}

\section{Résumé}

La question principale pour beaucoup de professeurs de droit pénal international est : dans quelle mesure les états parties appliquent correctement le statut de Rome? C'est une question pertinente pour toutes les régions mais particulièrement fascinante en Afrique. C'est ainsi en partie parce que tous les cas de situations préoccupantes devant la cour pénale internationale ('la cour') sont en Afrique. C'est aussi parce que l'Afrique en tant que région fait état d'une combinaison pernicieuse de manvais respect de la loi, de niveaux élevés de corruption, d'exploitation des ressources naturelles et d'une main d'oeuvre bon marché et parce que l'Afrique en tant que région a été victime des pires conflits qui existent depuis la deuxième guerre mondiale ('2nGM'), avec des niveaux de violence qui sont parmi les plus élevés dans le monde.

Une grande partie de l'analyse portant sur la question de l'application concerne l'adoption des lois et des procédures et la création d'une infrastructure juridique avec des juges, des procureurs et des avocats de la défense qualifiés et indépendants.

Un des éléments les plus difficiles à examiner, cependant, est la mesure dans la quelle les dispositions relatives au sexe dans le statut de Rome sont pareillement mises en application. C'est 
une question difficile pour un certain nombre de raisons. La première est parce qu'il n'est pas immédiatement évident que l'application du statut de Rome dans les systèmes nationaux exige une approche spécifiquement axée sur les sexes. Alors que l'identité sexuelle est très certainement un dispositif important dans le fonctionnement de la cour et des principes légaux applicables, les principes spécifiques au sexe ne sont pas nécessairement incorporés à la législation de domestication des états parties. Ceci est aggravé par les multiples définitions du mot "sexe". Dans le contexte du droit pénal international il est généralement admis de comprendre les crimes qui sont commis contre des hommes ou des femmes en raison de leur sexe, d'une manière qui affecte de façon disproportionnée les femmes et dans un contexte dans lequel l'identité sexuelle d'un individu dépend de normes, de règles ou d'exceptions sociales ou culturelles. Il y a également un point d'interrogation concernant la mesure dans laquelle la CPI elle-même applique bien son mandat de façon sensible et nuancée par rapport au sexe. En conclusion, le manque de protection des droits des femmes en Afrique est particulièrement grave.

L'examen de la protection en matière sexuelle est examiné dans le contexte d'un système incertain au niveau international, avec un besoin urgent et extrême de protection au niveau national. Il y a encore d'autres facteurs de complication : le droit pénal international n'a que très récemment identifié les crimes d'origine sexuelle (aspect que je discute brièvement ci-dessous). Ces crimes qui ont été identifiés sont exclusivement liés au viol des femmes dans les conflits et il y a une myriade d'agressions qui sont de type sexuel, comme je l'expose dans ce qui suit, qui ne sont pas encore reconnus comme des crimes dans les systèmes légaux internationaux ou nationaux.

Dans cet article, j'examine le développement des crimes d'ordre sexuel dans le droit pénal international, notant l'énonciation importante, mais étriquée des crimes sexuels contre des femmes. Je considère ensuite les multiples façons dont les femmes vivent et sont affectées par les conflits. En conclusion, je présente un bref résumé de certaines des insuffisances dans les poursuites criminelles internationales et la manière dont celles-ci devraient être améliorées au niveau international et national.

\section{Introduction}

Thirty-three African states have signed the Rome Statute of the International Criminal Court. ${ }^{1}$ Having signed and ratified the Rome Statute, signatory states are

\footnotetext{
${ }^{1}$ Rome Statute of the International Criminal Court, 2187 UNTS 90, 17 July 1998, entered into force 1 July 2002 (Rome Statute).African signatories to the Rome Statute are: Senegal, Ghana, Mali, Lesotho, Botswana, Sierra Leone, Gabon, South Africa, Nigeria, Central African Republic, Benin, Mauritius, Democratic Republic of the Congo, Niger, Uganda, Namibia, Gambia, United Republic of Tanzania, Malawi, Djibouti, Zambia, Guinea, Burkina Faso, Congo, Burundi, Liberia, Kenya, Comoros, Chad, Madagascar, Seychelles, Tunisia, Cape Verde, see ICC Assembly of States Parties' web presence <http://www.icc-cpi.int/Menus/ASP/states+parties/African+States/> accessed 3 July 2012.
} 
obliged to take steps to implement its provisions into national law. ${ }^{2}$ Implementation into national legal systems is one of the most important components of international criminal law relating to the Rome Statute. The principle of complementarity, well documented in the literature, creates a hierarchy of legal systems, with the national legal system identified as the primary and preferable system to prosecute international crimes. ${ }^{3}$ It is based on this hierarchy that international law practitioners, scholars and the ICC itself are assessing the extent to which states have, or are trying to implement the provisions of the Rome Statute into their national legal systems.

The key question for many international criminal law scholars is: to what extent are states parties properly implementing the Rome Statute? This is a question that is relevant to all regions but holds particular fascination in Africa. This is so in part because all the situation cases before the International Criminal Court ('the Court') are in Africa. It is also because Africa as a region has the pernicious combination of poor rule of law, high rates of corruption, exploitation of natural resources and cheap labour and because Africa as a region has been beset with some of the worst conflicts since World War II ('WWII'), with some of the highest rates of violence globally. ${ }^{4}$

Much of the analysis relating to the question of implementation focuses on the adoption of laws and procedures and the creation of a judicial infrastructure with independent and trained judges, prosecutors and defence lawyers. ${ }^{5}$

One of the more difficult elements to examine, however, is the extent to which the provisions relating to gender in the Rome Statute are similarly implemented. This is a difficult question for a number of reasons. The first is because it is not immediately clear that the implementation of the Rome Statute in national systems requires a specifically gendered approach. While gender is most certainly an im-

\footnotetext{
2 See arts 26 and 27 of the Vienna Convention on the Law of Treaties, 1155 UNTS 331, 23 May 1969, entered into force on 27 January 1980, regarding, respectively, the requirement to perform the obligations of the treaty in good faith and to not invoke the provisions of its internal law as a justification for its failure to perform a treaty. The manner and methodology of implementation will depend on the method of incorporation of international treaties specific to each signatory state.

${ }^{3}$ See Preamble to the Rome Statute: 'Emphasizing that the International Criminal Court established under this Statute shall be complementary to national criminal jurisdictions'; art 1, establishing the International Criminal Court as complementary to national jurisdictions; art 17(1)(a), providing that a case shall be inadmissible if 'The case is being investigated or prosecuted by a State which has jurisdiction over it, unless the State is unwilling or unable genuinely to carry out the investigation or prosecution.'

${ }^{4}$ See Bonita Meyersfeld, 'Why Africa' The World Today Chatham House (London, Aug-Sept 2008).

${ }^{5}$ See for example, the implementation of the Rome Statute in South Africa (the ICC Act) as discussed by Max du Plessis, 'South Africa's Implementation of the ICC Statute: An African Example' (2007) 5 Journal of International Criminal Justice 461; Anton Katz, 'An act of transformation: The incorporation of the Rome Statute of the ICC into national law in South Africa' (2003) 12 African Security Review 27; and Lee Stone, 'Implementation of the Rome Statute in South Africa' in Chacha Murungu and Japhet Biegon (eds), Prosecuting International Crimes in Africa (PULP 2011) 305.
} 
portant feature in the operation of the Court and the applicable legal principles, ${ }^{6}$ the gender-specific principles are not necessarily incorporated into the domesticating legislation of state parties. ${ }^{7}$ This is exacerbated by the multifaceted understanding of 'gender'. ${ }^{8}$ In the context of international criminal law it is generally understood to comprise crimes that are committed against men or women because of their sex, in a manner that disproportionately affects women and in a context in which the sexual identity of an individual is ascribed certain cultural or social norms, rules or expectations. ${ }^{9}$ There is also a question mark regarding the extent to

${ }^{6}$ There are several provisions in the Rome Statute that require a gender-specific approach. For exam-
ple, article 7(3) provides that '[f]or the purpose of this Statute, it is understood that the term "gender"
refers to the two sexes, male and female, within the context of society. The term "gender" does not
indicate any meaning different from the above' and art 21 (3) (applicable law) provides that the 'appli-
cation and interpretation of law pursuant to this article must be consistent with internationally recog-
nized human rights, and be without any adverse distinction founded on grounds such as gender as
defined in article 7, paragraph $3[\ldots]$ '. As far as the operation of the Court is concerned, art $42(9)$
requires the prosecutor to 'appoint advisers with legal expertise on specific issues, including, but not
limited to, sexual and gender violence and violence against children.' Art 54 further requires the
prosecutor to

$[\mathrm{t}$ ]ake appropriate measures to ensure the effective investigation and prosecution of crimes within the jurisdiction of the Court, and in doing so, respect the interests and personal circumstances of victims and witnesses, including age, gender as defined in article 7, paragraph 3 , and health, and take into account the nature of the crime, in particular where it involves sexual violence, gender violence or violence against children.

The rules relating to the protection of witnesses and victims (art 68) require the Court to 'take appropriate measures to protect the safety, physical and psychological well-being, dignity and privacy of victims and witnesses' and to 'have regard to all relevant factors, including age, gender as defined in article 7 , paragraph 3 , and health, and the nature of the crime, in particular, but not limited to, where the crime involves sexual or gender violence or violence against children.'

${ }^{7}$ For example, Commonwealth 'Model Law to Implement the Rome Statute of the International Criminal Court' (2004)

$<$ http://www.iccnow.org/documents/ModelLawToImplementRomeStatute_31Aug06.pdf> accessed 3 July 2012 makes no reference to the specificity of gender in the implementation provisions, including in those provisions relating to applicable law and the treatment of witnesses. The corresponding provisions in the Rome Statute contain important gender-specific components. See ibid. 8 The most authoritative is the definition contained in the Rome Statute. Art 7(3) of the Rome Statute defines gender as referring 'to the two sexes, male and female, within the context of society. The term "gender" does not indicate any meaning different from the above.' Chinkin defines gender-based crimes as 'crimes that are committed against men or women because they are men or women.' Christine Chinkin, 'Gender-Based Crimes' in Rüdiger Wolfrum (ed), Max Planck Encyclopedia of Public International Law (Max Planck Institute for Comparative Public Law and International Law and Oxford University Press 2011) para 1.

${ }^{9}$ Gender-based crimes which affect men because of their gender include the forced recruitment of boys and men into fighting forces or diamond mining during the conflict in Sierra Leone (see Valerie Oosterveld, 'Lessons from the Special Court for Sierra Leone on the Prosecution of Gender-Based Crimes' (2009) 17 American University Journal of Gender, Social Policy \& the Law 407, 407-08) and the killing of civilian men on the basis that they may become enemy combatants during the conflict in the Former Yugoslavia (see ICTY Trial Chamber, Prosecutor v Krstic, Judgment (2 August 2001) ICTY98-33; and Chinkin (n 8) para 1). For a criticism of the definition of 'gender' in the Rome Statute see Chinkin (n 8) paras 13-4. 
which the ICC itself is adequately implementing its mandate in a gender-nuanced and sensitive manner. ${ }^{10}$ Finally, the lack of protection of women's rights in Africa is particularly acute.

So the examination of gender protection is examined against the backdrop of an uncertain system at the international level, combined with an urgent and extreme need for protection at the national level. There are further complicating factors: international criminal law has only very recently identified gender-specific crimes (the history of which I discuss briefly below). Those crimes that have been identified relate exclusively to the sexual violation of women in conflict and there is a myriad of harm that is gender-specific, as I describe below, which is not yet categorised as criminal under either international or national legal systems.

In this article, I examine the development of gender-specific crimes in international criminal law, noting the important, yet narrow, enunciation of sexual crimes against women. I then consider the multiple ways in which women experience and are affected by conflict. Finally, I present a brief summary of some of the deficiencies in international criminal prosecutions and the way that these should be ameliorated both at the international and the national level.

\section{Historical overview of the prosecution of gender-specific war crimes}

\subsection{Traditional Conceptions of Women in War}

It is well established that transitional justice mechanisms, including international criminal prosecutions, do not properly represent the myriad ways in which women experience, contribute to, and are affected by conflict. ${ }^{11}$ The passage of the Rome Statute and its implementation in member states' national jurisdictions has seen success and limitations in respect of crimes committed against women. This article considers the development of international criminal law jurisprudence in respect of women's rights and proposes methods by which member states should implement the Rome Statute in a gendered manner.

Targeting women during a conflict is not new; however, the jurisprudential response is. ${ }^{12}$ Historically, transitional justice mechanisms have failed fully to address

\footnotetext{
10 See Vesna Nikolic-Ristanovic, 'Sexual Violence, International Law and Restorative Justice' in Doris Buss and Ambreena Manji (eds), International Law Modern Feminist Approaches (Hart Publishing 2005) 290 and Mark Drumble, 'Punishment Goes Global: International Criminal Laws, Conflict Zones, and Gender (In)equality’ (2000) 4 Canadian Women's Studies 23.

11 See in general, Oosterveld (n 9). See also Shelley Saywell, Women in War (Penguin Books 1985) 2.

12 For a discussion of the development of mass rape as a crime in international criminal law see: Bonita Meyersfeld, Domestic Violence and International Law (Hart Publishing 2010) 269-274; Kelly Askin, 'Prosecuting Wartime Rape and other Gender-Related Crimes under International Law: Extraordinary Advances, Enduring Obstacles' (2003) 21 Berkley Journal of International Law 288, 347; The-
} 
the specific ways in which women and sexual minorities endure human rights abuses. Neither the International Military Tribunal in Nuremberg nor its equivalent in Tokyo dealt satisfactorily with crimes against women. ${ }^{13}$ The London Charter did not mention rape although it was included in Local Council Law No. 10. ${ }^{14}$ While the Tokyo Tribunal included rape as a war crime in its mandate, acts of rape were not prosecuted. This is so notwithstanding the Rape of Nanking, during which over 20,000 women were raped by Japanese forces and Emperor Hirohito was well aware of the atrocities. ${ }^{15}$ The so-called 'comfort women' who were forced into sexual services for the Japanese military during WWII were abandoned in the peace negotiations by all the governments involved, including their own, and, in 1965, with the signing of the Japan-South Korea Basic Treaty, they were legally foreclosed from the possibility of reparations. ${ }^{16}$ Traditional views of chastity and morality prevented, and continue to limit, a national dialogue about the sexual exploitation and enslavement of women during WWII by the Japanese military (although non-judicial processes have developed in the form of the Women's International War Crimes Tribunal on Japan's Military Sexual Slavery). ${ }^{17}$

odor Meron, 'Rape as a Crime under International Law' (1993) 87 American Journal of International Law 424, 425-427; and James R Mchenry III, 'The Prosecution of Rape under International Law: Justice that is Long Overdue' (2002) 35 Vanderbilt Journal of Transnational Law 1269.

${ }_{13}$ Meron (n 12) 425-427. See also Chinkin (n 8) para 5; Barbara Bedont and Katherine Hall Martinez, 'Ending Impunity for Gender Crimes under the International Criminal Court' (1999) 6 The Brown Journal of World Affairs, 65.

${ }_{14}$ Control Council Law No. 10, Punishment of Persons Guilty of War Crimes, Crimes Against Peace and Against Humanity, 20 December 1945, 3 Official Gazette Control Council for Germany 50-55 (1946). Art II(1)(c) includes rape in the definition of crimes against humanity.

${ }^{15}$ Nikolic-Ristanovic (n 10) 273.

16 The Treaty on Basic Relations between Japan and the Republic of Korea, 22 June 1965 provided that South Korea agreed to demand no compensations, either at the government or individual level, after receiving $\$ 800$ million in grants and soft loans from Japan as compensation for its 1910-1945 colonial rule in the treaty. For a discussion of the plight of the so-called 'Korean Comfort Women' during and after WWII see in general Bang-Soon L. Yoon, 'Imperial Japan's Comfort Women from Korea: History and Politics of Silence-Breaking' (2010) The Journal of North-East Asian History.

17 See Women's International War Crimes Tribunal on Japan's Military Sexual Slavery, a tribunal established and organised by non-governmental organisations, was held in Tokyo from the 8th to 12th December 2000. Information about the Tribunal, its objectives and decisions, is available at <http://www1.jca.apc.org/vaww-net-japan/english/womenstribunal2000/whatstribunal.html> accessed 8 August 2011. For a discussion of the Tribunal, see Rumi Sakamoto, 'The Women's International War Crimes Tribunal on Japan's Military Sexual Slavery: A Legal and Feminist Approach to the "Comfort Women" Issue' (2001) 3 New Zealand Journal of Asian Studies 1, 49-58. The final paragraph of the judgment reads as follows:

The Crimes committed against these survivors remain one of the greatest unacknowledged and unremedied injustices of the Second World War. There are no museums, no graves for the unknown "comfort woman", no education of future generations, and there have been no judgement days for the victims of Japan's military sexual slavery and the rampant sexual violence and brutality that characterized its aggressive war. 
The 1949 Geneva Conventions and the two Additional Protocols contain provisions relating to women but the prohibitions, until recently, have not triggered prosecutions. ${ }^{18}$

There is an array of factors which, traditionally, have precluded women from prosecutorial processes. These have been canvassed extensively in the academic literature and one of the prominent explanations is the well-canvassed subject of gender discrimination and differentiation. ${ }^{19}$ The distinction between men and women in many societies often demarcates women as subordinate to men, particularly in political or public contexts. In times of post-conflict peace keeping, women's experiences tend to be subsumed into generic group experiences, such as religious or racial persecution, or sex-specific harm is deemed to be an unavoidable, tangential effect of war. Either way, the specific experiences of women during conflict situations remain unaddressed. For example, in post-apartheid South Africa, many women testified to the Truth and Reconciliation Commission about crimes committed against their husbands, sons or other male relatives; few identified themselves as primary victims. ${ }^{20}$

The reliance on gender stereotypes and hetro-normativity has also precluded women from post-conflict and post-oppressive regime prosecutions. The perpetuation of stereotypes tends to cast men as combatants and heroes and women as secondary participants, with the result that many forms of harm affecting women have not been categorised as legal wrongs. Harm perpetrated against women dur-

18 Art 27 of the Fourth Geneva Convention states that

Protected persons are entitled, in all circumstances, to respect for their person, their honour, their family rights, their religious conviction and practices, and their manners and customs. They shall at all times be humanely treated, and shall be protected especially against all acts of violence or threats thereof and against insults and public curiosity. Women shall be especially protected against any attack on their honour, in particular against rape, enforced prostitution, or any form of indecent assault.

Geneva Convention (IV) Relative to the Protection of Civilian Persons in Time of War, 75 UNTS 287, 12 August 1949, entered into force 21 October 1950. For a criticism of the link between the prohibition against violence and women's honour, see Bedont and Hall Martinez (n 13). Art 4(2)(e) of the Protocol Additional to the Geneva Conventions of August 12, 1949, and Relating to the Protection of Victims of Non-International Armed Conflicts (Protocol II), 1125 UNTS 609, 8 June 1977, entered into force 7 December 1978, provides that prohibited acts include 'outrages upon personal dignity, in particular humiliating and degrading treatment, rape, enforced prostitution and any form of indecent assault.' See in general Chinkin (n 8).

${ }^{19}$ See Beth Van Schaack, “The Grass That Gets Trampled When Elephants Fight”: Will the Codification of the Crime of Aggression Protect Women?' (September 2010), SSRN available at $<$ http://works.bepress.com/beth_van_schaack/3/> accessed 8 August 2011. See also Beth Van Schaack, 'The Crime of Aggression and Humanitarian Intervention on Behalf of Women' (2011) 11 International Criminal Law Review 3, 477. See also in general: Oosterveld (n 9) and Meyersfeld (n 12) 105-106.

${ }^{20}$ For an extensive discussion of the success of the TRC in respect of women's experiences see Fiona Ross, Bearing Witness: Women and the Truth and Reconciliation Commission in South Africa (Pluto Press 2003). See also the Statement by Dr Sheila Meintjies to the Truth and Reconciliation Commission's Women's Hearings (29 July 1997) <http://www.justice.gov.za/trc/special/women/meintjie.htm> accessed 8 August 2011. 
ing conflicts traditionally was viewed as inevitable consequences of instability and, at least implicitly, a permissible component of political strife.

There has been extensive change in this field in the past two decades. As I will discuss below, however, these are preliminary steps in creating international criminal prosecutorial systems which meet the needs of, and punish the crimes committed against women.

\subsection{Change}

In 1994 the landscape of transitional justice began to change. The decisions of the International Criminal tribunal for the Former Yugoslavia (ICTY) and the International criminal Tribunal for Rwanda (ICTR) (collectively referred to as the ad hoc tribunals) incorporated women into the judicial framework of international criminal law..$^{21}$ In Prosecutor v Akayesu, the ICTR applied the definition and jurisprudence of torture to mass rape during the Rwandan genocide. ${ }^{22}$ The ICTY followed suit in Prosecutor $v$ Kunerac, cementing the Akayesu precedent and confirming that widespread rape constitutes a war crime and crime against humanity. ${ }^{23}$ By combining the provisions of Common Article 3 of the Geneva Conventions and Article 3 of the ICTY Statute, the ICTY established the requisite elements for certain conduct to constitute mass rape under international criminal law. ${ }^{24}$ In Prosecutor $v$ Delalic and others (otherwise known as the infamous Celebici case) ${ }^{25}$ the ICTY, in keeping with Akayesu, employed the language of torture in describing the severe pain and suffering, both physical and psychological, caused by rape. It also acknowledged the psychological suffering may be exacerbated by social and cultural conditions and can be particularly acute and long lasting. ${ }^{26}$ The Tribunal concluded that it is difficult to envisage circumstances in which rape, by, or at the instigation of a public official, or with the consent or acquiescence of an official, could be considered as occurring for a purpose that does not, in some way, involve punishment, coercion, discrimination or intimidation.

21 See ICTR Trial Chamber I, Prosecutor v Akayesu, Judgment (2 September 1998) ICTR-96-4-T, para 597:

Like torture, rape is used for such purposes as intimidation, degradation, humiliation, discrimination, punishment, control or destruction of a person. Like torture, rape is a violation of personal dignity, and rape in fact constitutes torture when it is inflicted by or at the instigation of or with 22 Ibid. the consent or acquiescence of a public official or other person acting in an official capacity.

${ }^{23}$ ICTY Trial Chamber, Prosecutor v Kunerac, Judgment (22 February 2001) ICTY-96-23-T. See also Mchenry (n 12) 284.

${ }_{24}$ Meyersfeld (n 12) 270. For an analysis of this process see Mchenry (n 12) 1290-96.

25 The Trial Chamber held that the rape of any person is a despicable act which strikes at the very core of human dignity and physical integrity and that the condemnation and punishment of rape becomes all the more urgent where it is committed by, or at the instigation of, a public official, or with the consent or acquiescence of such an official. ICTY Trial Chamber, Prosecutor $v$ Delalic and others, Judgment (16 November 1998) ICTY-96-21-T.

26 Ibid. 
By accepting that mass rape and sexual violence may constitute the actus reus of the crimes of torture, genocide and crimes against humanity, the ICTR and ICTY brought gender-specific harm into the jurisprudence of international criminal law and the law of war. This had never been done. Prior to Akayesu there was no meaningful jurisprudence on violence committed against women as an unlawful act of war. In fact, Akayesu would not have contained a conviction for mass rape but for the fact that Judge Pillay, president of the ICTR at the time, insisted that the indictment include sexual violence. This was contentious, partly because technically it is not the domain of a judge to determine the substance of an indictment and also because prosecutors were reluctant to bring cases for which there was no precedent and for which there were no clear legal principles. Without this jurisprudence, however, it is unlikely that the Rome Statute would have included such robust provisions regarding the criminal elements of mass rape and sexual slavery, amongst others. The inclusion of women in the institutions of transitional justice, such as Louise Arbour, Ms. Carla del Ponte, Judges Elizabeth Odio Benito, Gabrielle Kirk McDonald, Navanethem Pillay, and Dorothee de Sampayo, has resulted in an expansion of the laws of war and international criminal law that will be felt for generations. ${ }^{27}$

This jurisprudence culminated in the historic criminalisation of rape and gender-based harm in the Rome Statute of the International Criminal Court. ${ }^{28}$

The jurisprudence of the ICC and the ad hoc tribunals was extended by the Special Court for Sierra Leone (SCSL). The Prosecutor of the SCSL prioritised gender, with the result that ten of the thirteen accused from Sierra Leone were charged with crimes relating to gender-based violence. ${ }^{29}$ In 2007 the SCSL found that forced marriage is a crime against humanity and in 2008, the Appeals Chamber held that forced marriage is a distinct, inhumane act of sufficient gravity to be considered a crime against humanity. ${ }^{30}$ The SCSL defined the crime of forced marriage as

a situation in which the perpetrator through his words or conduct, or those of someone for whose actions he is responsible, compels a person by force, threat of force, or coercion to serve as a conjugal partner result-

\footnotetext{
27 Meyersfeld (n 12) 269-70.

${ }^{28}$ For example, the crime of genocide includes the imposition of measures intended to prevent births within a group (article 6(d)); crimes against humanity include rape, sexual slavery, enforced prostitution, forced pregnancy, enforced sterilization, or any other forms of sexual violence of comparable gravity (article 7(1)(g)); war crimes include rape, sexual slavery, enforced prostitution, forced pregnancy, enforced sterilization or any other form of sexual violence constituting a grave breach of the Geneva Conventions (article 8(2)(b)).

29 These accused were Charles Taylor, three Armed Forces Revolutionary Council (AFRC) accused, three Revolutionary United Front (RUF) accused, Sam Bockarie, Johnny Paul Koroma, and Foday Sankoh. See Oosterveld (n 9) 408.

30 SCSL Appeals Chamber, Prosecutor v Brima, Kamara and Kanu, Judgment (22 February 2008) Case No.SCSL-04-16A, paras 181-185. For a discussion of the SCSL's approach to forced marriage see Oosterveld (n 9) 414-24.
} 
ing in severe suffering, or physical, mental or psychological injury to the victim. 31

This development was particularly important as the crime encompasses an array of harm in addition to sexual violence, including a broad range of conjugal duties, ${ }^{32}$ abduction, unwanted pregnancies, enforced pregnancies, physical abuse, miscarriages, death threats, being forced to live with and be loyal to an individual whom one fears and despises, forced relocation, mental trauma and lasting stigma. ${ }^{33}$ The Appeals Chamber identified that 'unlike sexual slavery, forced marriage implies a relationship of exclusivity between "husband" and "wife", which could lead to disciplinary consequences for breach of this exclusive arrangement."34

The United Nations Security Council (UNSC) too has played an important role in the specification of international prohibitions against violence against women in conflict. On 31 October 2000, Security Council Resolution 1325, passed unanimously, specifically addressed the impact of war on women, and women's contributions to conflict resolution and sustainable peace. UNSC Resolution 1325 calls 'all parties to armed conflict to take special measures to protect women and girls from gender-based violence, particularly rape and other forms of sexual abuse, and all other forms of violence in situations of armed conflict.'35 The Resolution had an impact: in 2007, partly in response to Resolution 1325, India sent the first ever allfemale police unit to participate in the UN peacekeeping operations in Liberia. In a country where more than 90 percent of the women have survived some form of sexual violence, the all-female police force was an important manifestation of the empowerment of women, greatly strengthening the transitional justice process. ${ }^{36}$ This was unprecedented.

On 19 June 2008 the UN Security Council voted unanimously to classify rape as a tactic of war and a threat to international security. ${ }^{37}$ UNSC Resolution 1820 noted that women and girls are 'particularly targeted by the use of sexual violence, including in some cases as a tactic of war to humiliate, dominate, instil fear in, disperse and/or forcibly relocate civilian members of a community or ethnic group.'38 On 30 September 2009 the Security Council adopted Resolution 1888

\footnotetext{
31 Brima (Appeal) (n 30) 196.

32 Oosterveld (n 9) 409-410.

${ }_{33}$ SCSL Trial Chamber, Prosecutor v Brima, Kamara and Kanu, Judgment (June 20, 2007) SCSL-04-16-T, para 37-50 (Doherty J. dissenting).

34 Brima (Appeal) (n 30) 195. The Prosecutor of the ICC has also referred to forced marriage in the conflict in the Democratic Republic of Congo. ICC, Prosecutorv Katanga and Ngudjolo Chui, Prosecution's Submission of Public Version of Document Containing the Charges (24 April 2008) ICC01/04-01/07, para 89.

35 UNSC Res 1325(2000), 31 October 2000, S/RES/1325(2000), para. 10.

36 See 'Indian Women Police Inspire Liberian Women to Join Liberia's Police Force' New Liberian (Liberia, 14 November 2008) <http://newliberian.com/?p=470> accessed 8 August 2011. See also Meyersfeld (n 12).

${ }^{37}$ UNSC Res 1820(2008) to End Sexual Violence in Conflict, 19 June 2008, S/RES/1820(2008).

38 Ibid Preamble.
} 
which specifically mandates peacekeeping missions to protect women and children from rampant sexual violence during armed conflict. ${ }^{39}$ Importantly, this Security Council Resolution recognises that allowing peacekeeping forces to respond to and prevent acts of sexual violence can significantly contribute to the maintenance of international peace and security. ${ }^{40}$ Additional relevant Security Council resolutions include UNSC Res 1960.41

There have also been important regional developments. On 1 March 1996, the Inter-American Commission on Human Rights held that rape on two occasions of a school teacher by the Peruvian army constituted torture in the context of conflict. ${ }^{42}$ In the case of Miguel Castro-Castro Prison v Peru, the Inter-American Court followed the jurisprudence of the ICTR and adopted a wider definition of sexual violence committed against women. ${ }^{43}$ The European Court of Human Rights has also included rape within the definition of in Aydin $v$ Turkey, holding that rape 'of a detainee by an official of the State must be considered to be an especially grave and abhorrent form of ill-treatment given the ease with which the offender can exploit the vulnerability and weakened resistance of his victim.' ${ }^{34}$

These developments have not put an end to the debate about the criminalization of gender-specific harm and, post 2006, bias against the inclusion of such harm remains. International and national prosecutors still rely on stereotypes regarding men and women, victims and perpetrators, without understanding or taking into account the nuances of harm committed. Contexts of militarization also mobilize ideas of hetero-normativity to define military strength or depict enemy vulnerability and these assumptions tend to inform prosecutorial decisions. To the extent that there have been post-conflict prosecutions of war-crimes committed against women, the focus has been on sexual violence, which is packaged with assumptions of universality - that all women have the same experience - and objectification. ${ }^{45}$ The almost exclusive focus on sexual violence revives the perception

${ }^{39}$ UNSC Res 1888(2009), 30 September 2009, S/RES/1888(2009).

40 See art 1:

Reaffirms that sexual violence, when used or commissioned as a tactic of war in order to deliberately target civilians or as a part of a widespread or systematic attack against civilian populations, can significantly exacerbate situations of armed conflict and may impede the restoration of international peace and security; affirms in this regard that effective steps to prevent and respond to such acts of sexual violence can significantly contribute to the maintenance of international peace and security; and expresses its readiness, when considering situations on the agenda of the Council, to take, where necessary, appropriate steps to address widespread or systematic sexual violence in situations of armed conflict.

${ }^{41}$ UNSC Res 1960(2010), 16 December 2010, S/RES/1960(2010).

${ }^{42}$ Inter-American Court of Human Rights, Fernando and Raquel Mejia v Peru, Case 10.970, Report No. 5/96, OEA/Ser.L/V/II.91 Doc. 7 at 157 (1996).

${ }^{43}$ Inter-American Court of Human Rights, Miguel Castro-Castro Prison v Peru, Inter-Amer. Ct. H.R. (ser. C.) No. 160 (Nov. 25, 2006).

${ }_{44}$ European Court of Human Rights, Aydin v Turkey, App no 57/1996/676/866 (25 September 1997) para 83.

45 See Oosterveld (n 9) 5 and 10. 
of women as solely sexual and reproductive beings. Such focus also ignores the multi-faceted way in which women experience harm, particularly in Africa where poverty, poor health and susceptibility to terminal infection affects women disproportionately to men. ${ }^{46}$ The successful prosecution of sexual violence against women in war is a laudable development but we should not forget that it is only a first step and one that is yet to be fully implemented, particularly in Africa. Women in conflict experience a range of harm, which aims to or results in hurting or impairing an aspect of women which is peculiar to their gender. ${ }^{47}$

\section{Types of harm women experience during conflict}

There are several ways in which women are involved in or experience conflict. Women may be combatants, direct victims of conflict and victims of post-unrest exigencies. ${ }^{48}$ Women suffer a range of harm that affects them precisely because they are women and because women as a group play a particular role in society that is deliberately targeted by enemy forces. ${ }^{49}$ Not all such harm is criminal (nor should all forms of harm fall under a criminal rubric), but many components are sufficiently egregious to warrant judicial attention. It is also important to note that women not only endure harm; they are also the perpetrators of harm. ${ }^{50}$ This does not change the analysis, however, of how international criminal law fails to map the forms of harm women perpetrated against women.

\subsection{Mass Killing}

In 2008, a former UN peacekeeping commander testified that '[i]t has probably become more dangerous to be a woman than a soldier in an armed conflict. ${ }^{51}$ The

\footnotetext{
46 These factors are identified as impediments to justice in UN Women, 'Progress of the World's Women In Pursuit of Justice' (2011-2012) < http://progress.unwomen.org/> accessed 8 August 2011. See Allen Buchanan, Justice, Legitimacy and Self-Determination (Oxford University Press 2006) 79. See also Martha Nussbaum, Women and Human Development (Cambridge University Press 2000) 1.

47 Susan McKay and Dyan Mazurana, Where are the Girls? Girls in Fighting Forces in Northern Uganda, Sierra Leone and Mozambique: Their Lives During and After War (Rights and Democracy 2004) 91-93 (women and girls were recruited into fighting forces where they fulfilled roles of cook, porters, caretakers, labourers in diamond mines and as 'wives' of the combatants).

${ }^{48}$ For an extensive and still relevant account of women's diverse and unexpected experiences of war, see Saywell (n 11).

${ }^{49}$ See Chinkin (n 8) paras 1-5.

${ }^{50}$ ICTR Trial Chamber, Prosecutor v Pauline Nyiramasubuko, Arsène Shalom Ntahobali, Sylvain Nsabimana, Alphonse Nteriryayo, Joseph Kanyabashi, Élie Ndayambaje Judgment (24 June 2011) ICTR-98-42-T. See Carrie Sperling, 'Mother of Atrocities: Pauline Nyiramasuhuko's Role in the Rwandan Genocide' (2005-2006) 33 Fordham Urban Law Journal 637.

${ }^{51}$ Kate Snow, Christina Romano and Imaeyen Ibanga, Rice, 'Rape Shouldn’t Be War Weapon U.N. Calls for End to Sexual Violence Against Women During Conflicts' ABC NEWS (July 2008) $<$ http://abcnews.go.com/GMA/rice-rape-warweapon/story?id=5364523>accessed 8 August 2011. See also Van Schaack (n 19).
} 
statistics bear this out: by the 1990s, nine out of ten people who died in war from direct and indirect effects were civilians. ${ }^{52}$ This is due to a change in war technology and strategy. Aerial bombardment usually results in the destruction of infrastructures such as power plants, water works, hospitals, and industrial plants and communications systems. ${ }^{53}$ There are fewer face-to-face battles, with the result that warfare is located in civilian cities, towns, and villages - and the vast majority of civilians are women. In Rwanda, an estimated 40 to 45 percent of those killed in the genocide were women. ${ }^{54}$ In the war in Sierra Leone the killing of civilians was found to constitute a targeted campaign by the RUF and AFRC. 55 25.6\% of victims of mass killings comprised women (the Commission has the testimony of 1149 individuals). ${ }^{56}$

One of the major contributors to civilian death is landmines. ${ }^{57}$ Landmines and cluster munitions have been used to target civilian populations (predominantly women and children). More than 100 million landmines and unexploded ordnance lie dispersed and unmarked in fields, roadways, pasturelands, and near borders in 90 countries throughout the world. ${ }^{58}$ From 15,000 to 20,000 people are maimed or killed each year by landmines and more than 70 percent of the reported victims are civilians. ${ }^{59}$

The objective of landmines is to ensure the disruption of a community's life and livelihood without the presence of a military force. Landmines are deliberately placed in agricultural fields and along routes to water sources and markets. This impedes the production of food, inhibits the development and recovery of the community and extends the conflict into the non-combatant zone of civilians. ${ }^{60}$ Women and children are common casualties in agrarian and subsistence-farming structures particularly. In Bajaur, Pakistan, thousands of landmines have been scat-

52 Patricia Heynes, 'War And Women' (13 March 2003)

$<$ http://www.zmag.org/content/showarticle.cfm?ItemID=3229>accessed 8 August 2011.

${ }^{53}$ Heynes (n 52).

54 Ibid.

55 Truth and Reconciliation Commission Sierra Leone, Chapter Three Women and the Armed Conflict in Sierra Leone Witness To Truth: Report of the Sierra Leone Truth and Reconciliation Commission Vol 3B, $<$ http://www.sierra-leone.org/Other-Conflict/TRCVolume3B.pdf $>$ accessed 8 August 2011, p 152 para 259.

56 Sierra Leone TRC Report (n 55) para 201

${ }^{57}$ Convention on the Prohibition of the Use, Stockpiling, Production and Transfer of Anti-Personnel Mines and on their Destruction, Oslo, 2956 UNTS 211, 18 September 1997, entered into force 1 March 1999 (commonly referred to as the 'Mine Ban Treaty').

${ }^{58}$ Heynes (n 52).

${ }^{59}$ See the Preamble to the Mine Ban Treaty (n 58 above):

Determined to put an end to the suffering and casualties caused by anti-personnel mines, that kill or maim hundreds of people every week, mostly innocent and defenceless civilians and especially children, obstruct economic development and reconstruction, inhibit the repatriation of refugees and internally displaced persons, and have other severe consequences for years after emplacement.

See also Heynes (n 52).

${ }^{60}$ Heynes (n 52). 
tered on the Pakistan-Afghanistan border by the Soviet military during Soviet conflict. Women and girls constitute almost 35 percent of mine victims, injured while fetching fodder for animals, crossing agricultural fields, and carrying out their daily activities. Yet mine awareness sessions are provided predominantly in mosques and schools to men and boys who are then relied upon to educate women and girls at home. Nearly one-half of land in Cambodia, where one of every 236 people is an amputee due to landmine injury, is unsafe for cultivation and human use. ${ }^{61}$ So as the recovery from war continues, it is likely that an even greater percent of those injured and killed by landmines will be women and children as they return to peacetime sustenance activities, collecting firewood and water, tending animals and farming. ${ }^{62}$ This is especially true in Africa where women are responsible for $80 \%$ of agricultural production. ${ }^{63}$

\subsection{Long term Economic Hardship}

Long-term economic hardship is one of the primary ways in which women suffer during and after war. ${ }^{64}$ Policies of property destruction and laying waste target civilians specifically. Just as mass rape, this is not a side-effect of war but a deliberate component of conflict strategies. The disintegration of an enemy community is a great strength to combatants. And it is this disintegration of which women are the primary victims. For example, the burning of homes, towns and villages, the poisoning of food and water sources, and the destruction of livestock, buildings and other forms of property, are all methods of de-stabilizing a community. Without such resources, the community is forced to scatter, losing solidarity, uniformity and strength.

As with many violations, economic hardship is a harm which operates on a continuum. It may begin during the conflict but its end perpetuates well beyond the final handshake across the negotiating table. In communities where men are wage earners or are responsible for the income of the family, the deliberate killing

\footnotetext{
${ }^{61}$ Ibid.

62 Ibid.

${ }^{63}$ See USAID Fact Sheet, 'Food Security and Gender' < pdf.usaid.gov/pdf_docs/PNADR706.pdf> accessed 8 August 2011. See also FAO Women and Population Division, 'Women and Sustainable Food Security' <http://www.fao.org/sd/fsdirect/fbdirect/FSP001.htm> accessed 8 August 2011. See also Yemisi I. Ogunlela and Aisha A. Mukhtar, 'Gender Issues in Agriculture and Rural Development in Nigeria: The Role of Women' (2009) 4(1) Humanity \& Social Sciences Journal 19-30.

${ }^{64}$ See Inter-Agency Standing Committee Task Force on Gender and Humanitarian Assistance, Guidelines for Gender-based Violence Interventions in Humanitarian Settings Focusing on Prevention of and Response to Sexual Violence in Emergencies (2005) 50 (hereinafter Guidelines for Gender-based Violence Interventions in Humanitarian Settings). See also United Nations High Commissioner for Refugees, Sexual and Gender-Based Violence against Refugees, Returnees and Internally Displaced Persons Guidelines for Prevention and Response (2003). The long-term consequences of war for women are discussed by Jeanelle Ferril, 'A Call for New Justice: Victims of Sexual Violence in Africa/s Internal Conflicts' (2008) 4 Florida International University Law Review 333, 336.
} 
of male community members will ensure the impoverishment of a community, especially where women are precluded from meaningful or gainful employment.

The larger percentage of farmers in Asia and Africa are women. Women are responsible for up to 80 percent of food produced in many parts of Africa. When maimed, they lose the ability to farm and feed their family; and their husbands and family often abandon them, leaving such individuals indigent and vulnerable to sexual exploitation. Women often are required to head families in post-unrest situations but without inheritance rights. Such women have no claim to property to which male relatives alone are entitled. ${ }^{65}$

Many young widows raising children in poverty have had to turn to prostitution as a survival strategy. In regions such as Nepal and Bangladesh, where girls are trafficked into Indian brothels, the daughters of widows are more likely to be taken out of school to help their mothers and are particularly at risk of being trafficked into prostitution. ${ }^{66}$ In the war-torn countries of Angola, Bosnia and Herzegovina, Kosovo, Mozambique, and Somalia, the majority of adult women are widows who, without the support of a male breadwinner, are required to provide an income in environments which may not be conducive to women in the work place. ${ }^{67}$ Seventy percent of Rwandan children are supported solely by mothers, grandmothers, or oldest girl children. Girls in Rwanda are heads of family for an estimated 58,500 households. ${ }^{68}$ In Kosovo alone, where an estimated 10,000 men died or disappeared, many widows who returned from refugee camps had no social safety nets or advocacy organizations and became indigent and socially marginalized. ${ }^{69}$

\subsection{Displacement}

The scale and nature of war in the late 20th century has resulted in unprecedented numbers of people fleeing conflict, such that the displacement of people by war in the 1990 s has had more severe public health impact, in many situations, than the conflict itself. ${ }^{70}$

Women are particularly vulnerable to, and bear significant consequences of, forced displacement. ${ }^{71}$ Eighty percent of the world's refuges and internally displaced persons are women and children. ${ }^{72}$ In Sierra Leone $36.9 \%$ of victims of forced displacement were women (the Commission has the testimony of 2941 individuals). ${ }^{73}$ This is the most common violation recorded by the Commission

\footnotetext{
${ }^{65}$ Heynes (n 52).

${ }^{66}$ Ibid.

${ }^{67}$ Ibid.

${ }^{68}$ Ibid.

${ }^{69}$ Ibid.

70 Ibid.

71 Approximately $50 \%$ of the world's refugee population are women and girls. See UNHCR, 'Refugee

Women' <http://www.unhcr.org/pages/49c3646c1d9.html> accessed 8 August 2011.

72 Heynes (n 52).

${ }^{73}$ Sierra Leone TRC Report (n 55) para 201.
} 
and accounts for $23.5 \%$ of the violations committed against women as opposed to only $19.3 \%$ of the violations committed against men. ${ }^{74} \mathrm{~A}$ component of this experience which relates to women specifically is the difficulty in providing food and care for children, the elderly and sick relatives during and after displacement.

In refugee camps women and girls are more exposed to contaminated water supplies and human waste than men. ${ }^{75}$ Women and girls tend to be responsible for basic household needs, including procuring food, fuel, fodder, and water and for disposal of waste. This compels women to operate outside refugee camps, towns or cities, making them increasingly vulnerable to acts of harm and particularly rape. ${ }^{76}$ It has been reported that refugee women and girls have a higher mortality rate than men and boys because systems of health services and food provision in refugee camps privilege men and boys over women and girls. ${ }^{77}$ Rwandan refugee families headed by women suffered more malnutrition than those headed by men in an eastern Zaire refugee camp..$^{78}$ In South Africa women generally endured displacement as a result of the Group Areas Act. Women were displaced or abandoned in unknown parts of the country where their association with political activism led to their social isolation. ${ }^{79}$

Sadly, women's rights are also violated by humanitarian aid workers in displacement camps. ${ }^{80}$ They may be forced to barter sex for the aid to which they are entitled. In February 2002, The United Nations High Commissioner for Refugees (UNHCR) and Save the Children released a report on their investigation into allegations of sexual abuse of West African refugee children in Guinea, Liberia, and Sierra Leone. ${ }^{81}$ Their interviews with 1500 women, men and children refugees revealed that girls between the ages of 13 and 18 were sexually exploited by male aid workers, many of whom were employed by national and international nongovernmental agencies and the UN, and also by UN peacekeepers and community leaders. "They say "a kilo for sex," reported a woman from Guinea about the rampant extortion of sex for food by aid workers. A man interviewed stated that with-

\footnotetext{
${ }^{74}$ Ibid 136.

${ }^{75}$ Heynes (n 52).

76 See Guidelines for Gender-based Violence Interventions in Humanitarian Settings (n 64) 58.

77 Heynes (n 52).

78 Ibid.

${ }^{79}$ South Africa, vol. 4, ch 10, 305.

${ }^{80}$ See UNHCR, 'Extensive abuse of West African refugee children reported' (Press Release, 26 February 2002) < http://www.unhcr.org/cgi-

bin/texis/vtx/news/opendoc.htm?tbl=NEWS\&id=3c7bf8094>accessed 8 August 2011. See also

Sierra Leone TRC Report (n 55) para 6.

${ }^{81}$ See report of the on the activities of the Office of Internal Oversight Services: UN SecretaryGeneral, 'Investigation into sexual exploitation of refugees by aid workers in West Africa' (11 October 2002) A/57/465 <http://www.un.org/depts/oios/reports/a57_465.htm>accessed 8 August 2011.
} 
out a sister, wife or daughter to 'offer the NGO workers', one doesn't have access to oil, tents, medicines, loans, education and skill training, and ration cards. ${ }^{82}$

\subsection{Sexual and Reproductive-Related Violence}

The mass rape of women in war is historic. ${ }^{83}$ While rape in war has long been a prohibited act (the international rules of war prohibit attacks upon civilians and the use of certain 'illegitimate' weapons), it has been 'given license, either as an encouragement for soldiers or as an instrument of policy. ${ }^{94}$

Sexual violence, which includes rape, forced sexual relations with third parties, including instances of forced intra-familial sex or forced witnessing of rape of family members, is particularly prolific in current and recent African conflicts. ${ }^{85}$ The refusal to comply with the enforced activity results in death. ${ }^{86}$ Sexual violence during a conflict has two broad elements of harm. The first is the criminal act and the second is the conspiracy of silence. The criminal act itself involves the violation of a person based on or intended to offend the sexual identity of the individual. The use of rape as a weapon of war during the genocides in Rwanda and the Former Yugoslavia, with the specific intent of linking sexual violence to social destruc-

\footnotetext{
82 See Heynes (n 52). In Sierra Leone girls and women were forced to pay aid workers for aid benefits - to which they were entitled - with sex or they and family members would not be able to obtain aid. Sierra Leone TRC Report (n 55) 86.

${ }^{83}$ For a detailed discussion of the background, development, elements and application of the crime of mass rape in international law, see: Askin (n 12) 347; Meron (n 12) 425-427.

${ }^{84}$ See Meron (n 12) 425-427 (describing how rape by soldiers has been prohibited by the law of war for centuries, and 'violators have been subjected to capital punishment under military codes, such as those of Richard II (1385) and Henry V (1419).' Ibid, 425.

85 It is estimated that 250,000-500,000 women and girls were raped during the 1994 genocide in Rwanda, UN Women, 'Facts \& Figures on Peace \& Security'

$<$ http://www.unifem.org/gender_issues/women_war_peace/facts_figures.php $>$ accessed 8 August 2011 (hereinafter Facts \& Figures on Peace \& Security), citing UN Special Rapporteur to the Commission on Human Rights, 'Report on the Situation of Human Rights in Rwanda' (29 January 1996) E/CN.4/1996/68, para 16. In Sierra Leone, 50,000-64,000 internally displaced women were sexually attacked by combatants, Facts \& Figures on Peace \& Security, citing Physicians for Human Rights, 'Executive Summary' War-Related Sexual Violence in Sierra Leone: A Population-based Assessment (2002) 3. See Human Rights Watch, 'We'll Kill You if You Cry': Sexual Violence in the Sierra Leone Conflict (2003) 25-50 $<$ http://www.hrw.org/reports/2003/01/15/well-kill-you-if-you-cry>accessed 8 August 2011 (reporting acts of sexual violence including rape with objects such as weapons or burning wood, sexual mutilation, forced pregnancies, forced abortion and sexual slavery). See also Physicians for Human Rights, War Related Sexual Violence in Sierra Leone: A Population Based Assessment (2000) 2-4. For a discussion of sexual violence in Africa see Ferril (n 64). For a discussion of rape as a political mechanism during elections in Zimbabwe, see AIDS-Free World, Electing to Rape: Sexual Terror in Mugabe's Zimbabwe (10 December 2009) <http://allafrica.com/view/resource/main/main/id/00011983.html> accessed 3 July 2012.

86 See Guidelines for Gender-based Violence Interventions in Humanitarian Settings (n 64) 50: 'Between 50,000 and 64,000 internally displaced women in Sierra Leone reported experiencing sexual violence at the hands of armed combatants. Half of internally displaced women who had face-to-face contact with combatants reported experiencing sexual violence.'
} 
tion, resulted in the prohibition of mass rape as a crime against humanity, a war crime and an instrument of genocide in the Rome Statute. ${ }^{87}$

The second component is the silence surrounding rape and sexual violence by both men and women. Cultural imperatives often discourage discussion about one's private affairs. The social abjection of women is very much a component, for example, of mass rape. The rapes in Rwanda, Darfur and the Former Yugoslavia were (and are) intended to 'spoil' the purity of women, to offend the honour of men and to impregnate the victims, resulting in the birth of children of enemy ethnicity. ${ }^{8} 8$

Survivors of rape may carry the stigma of humiliation and defeat which may result in social ostracization. Whereas torture, detention and other crimes committed against men are honoured after a conflict, rape is met with a different reaction: the victims are shunned, silenced or blamed and their status is deflated rather then elevated as a result of the violations they experience. After the Rwandan genocide, many rape survivors were isolated, suspected of willing association with the enemy, shunned by their community and consigned to a life of dependency and isolation, rather than independence and integration.

Not every rape committed during a conflict fulfils a standard of extremity that triggers the provisions of international criminal law. ${ }^{89}$ It was the unbridled com-

\footnotetext{
${ }^{87}$ Both the ICTR and ICTY Statutes define rape as a crime against humanity when it is committed as part of an armed conflict, or a widespread or systematic attack against a particular segment of a civilian population. See Statute of the International Criminal Tribunal for Rwanda, available at <http://www.ictr.org/ENGLISH/basicdocs/statute/2007.pdf> accessed 20 July 2009 (hereinafter the ICTR Statute) and Statute of the International Criminal Tribunal for the Former Yugoslavia, available at <http://www.icty.org/sid/135> accessed 20 July 2009 (hereinafter the ICTY Statute) respectively. Article $3(\mathrm{~g})$ of the ICTR Statute defines rape as a crime against humanity when it is 'committed as part of a widespread or systematic attack against any civilian population on national, political, ethnic, racial or religious grounds.' The ICTR Statute also makes reference to the violations of Article 3 Common to the Geneva Conventions of 12 August 1949 for the Protection of War Victims, and of Additional Protocol II thereto of 8 June 1977, which include '[o]utrages upon personal dignity, in particular humiliating and degrading treatment, rape, enforced prostitution and any form of indecent assault.' Article 4(e) of the ICTR Statute. The ICTY Statute includes rape as a crime against humanity when it is 'committed in armed conflict, whether international or internal in character, and directed against any civilian population.' Article 5(g) of the ICTY Statute.

88 See Jonathan Short, 'Sexual Violence as Genocide: The Developing Law of the International Criminal Tribunals and the International Criminal Court' (2003) 8 Michigan Journal of Race and Law 503 and Sherrie L. Russell-Brown, 'Rape as an Act of Genocide' (2003) 21 Berkeley Journal of International Law 350.

89 Mass rape, in order to constitute a crime against humanity, must be widespread or systematic. ICTY Trial Chamber, Prosecutor v Kunarac, Judgment (22 February 2001) ICTY-96-23-T, para 417. According to the ICTY, the adjective 'widespread' 'connotes the large-scale nature of the attack and the number of its victims.' Ibid, para 428 (citing the Commentary of the International Law Commission in its Draft Code of Crimes against Peace and Security of Mankind). The adjective 'systematic' 'signifies the organized nature of the acts of violence and the improbability of their random occurrence.' Ibid, para 429.
} 
mission of rape, over an extended period of time and the creation of an environment of terror that distinguished mass rape from random instances of rape. ${ }^{90}$

\subsection{Forced Marriage, Abduction and Recruitment}

Conflicts have seen women captured as 'property' of combatants and forced into the role of so-called 'bush wives' or members of 'harems'. This is because

Governments on all sides of war have initiated, accommodated, and tolerated military brothels under the aegis of "rest and recreation" for their soldiers, with the private admission that a regulated system of brothels will contain male sexual aggression, limit sexually transmitted diseases in the military, and boost soldiers' morale for war. ${ }^{91}$

This captivity allows for sanctioned mass rape by combatants. The period of slavery is prolonged and comprises multiple, at times innumerable, rapes. Women may become the property of individual combatants (this may also constitute forced marriage) or a group of combatants, whom they serve on an on-going basis.

In Sierra Leone captured women were scarred with the initials 'RUF' cut into their bodies, putting the women further at risk if they were captured by government soldiers or allied militia, who would think they were rebels. ${ }^{92}$ Women in Sierra Leone were also forcibly recruited and compelled to take part in the hostilities. ${ }^{93}$

The capture of women by combatants may not be exclusively, or even predominantly, sexual and as such is not encompassed in the crime of sexual slavery. It may also involve the imposition of the status of marriage and a conjugal association by force, or threat of force. The gravamen of the offense is the assertion of a claim of right and ownership by the 'husband' over the 'wife', which involves the right to demand a whole range of 'conjugal duties' (including, but not at all limited to, non-consensual sex) in exchange for support and protection. This was recognised by the Sierra Leone Special Court which defined the crime against humanity of forced marriage as involving 'forced conjugal association with another person resulting in great suffering, or serious physical or mental injury on the part of the victim. ${ }^{94}$

\footnotetext{
90 The ICTY went further and stated that the attack must be 'either "widespread" or "systematic," thereby excluding isolated and random acts.' Ibid, para 427.

${ }^{91}$ Heynes (n 52).

92 Sierra Leone TRC Report (n 55) paras 208-213 and 219.

${ }_{93}$ Ibid paras 214-217.

${ }^{94}$ Brima (Appeal) (n 30) 181-185.
} 


\subsection{Reproductive violence}

Reproductive violence is a form of sexual violence and includes forced impregnation, enforced sterilization, and the limitation or denial of reproductive freedom. ${ }^{95}$ As is the case with economic hardship, the harm is not limited to the original act of rape but continues well after the conflict expires. Enforced pregnancy is a longterm and extreme violation of an individual woman's autonomy and bodily integrity.

National abortion laws and imperatives against access to safe abortion should not impede women's access to reproductive assistance and choice. ${ }^{96}$ Such ideological reluctance may exacerbate the injury of the rape, extending the harm beyond the act itself. The Sierra Leone Truth Commission found that there were women who became pregnant and were not permitted by their rapist or another to obtain abortion. ${ }^{97}$ There was also evidence of enforced sterilisation. The ICC Elements define enforced sterilisation as follows: 'The perpetrator deprived one or more persons of biological reproductive capacity' and 'the conduct was neither justified by the medicine or hospital treatment of the person or persons concerned nor carried out with their genuine consent.' 98 According to the Sierra Leone Truth Commission, forced sterilisation 'includes acts committed upon women including during the war in Sierra Leone, such as the removal of foetus, uterus, castration, destruction of reproductive organs, as well as medical sterilisation without consent. ${ }^{\prime 9}$ Although this crime was not listed in the Sierra Leone Special Court Statute, the Commission found that

the mutilation of Sierra Leonean women by disembowelling them, the cutting open of the uterus whichleads to the removal of the foetus results in sterilisation should be recognizedas enforced sterilisation at the same time as these acts also qualify as "othersexual violence". The numerous acts of violence on pregnant women that werereported include the cutting open of a pregnant woman's uterus and theremoval of the foetus, the mutilation of her organs thus constitute enforcedsterilisation as well as mutilation and cruel and inhuman treatment. ${ }^{100}$

In Sierra Leone, women who had been subject to specific forms of sexual violence developed fistula vesico-vaginal fistula (an abnormal tract between the bladder and the vagina which results in uncontrollable urinary leakage from the vagina. This

\footnotetext{
${ }^{95}$ Chinkin (n 8) paras 14-15.

96 Ibid.

${ }^{97}$ Sierra Leone TRC Report, 'Vol Three B Chapter Three, Women and the Armed Conflict in Sierra Leone' (n 55) para 185, p 131.

98 See the ICC Elements, at Article 7(1)(g)-5. The deprivation is not intended to include birth control measures, which have a non-permanent effect in practice. It is understood that 'genuine consent' does not include consent obtained through deception. Sierra Leone TRC Report (n 56) para 186.

${ }_{99}$ Sierra Leone TRC Report (n 55) para 186.

100 Ibid.
} 
rarely exists as a condition in industrialized societies and is predominant as a result of trauma to the reproductive organs).

When victims of rape do give birth, the children may be viewed as 'enemy children' or 'children of rebels.' In the Former Yugoslavia, survivors of rape camps reported that as soon as they became visibly pregnant, they would be released to give birth to the new generation of Serb children. As a result, both the mothers and their children are ostracized and continue to suffer the effects of the rape well after the culmination of the conflict. This in turn increases the risk of economic hardship.

Miscarriages may be intentionally triggered. Women also miscarry as an indirect result of beatings and maltreatment. The risk of miscarriage and maternal mortality increases as a result of a lack of access to health, either because such facilities are not available or because women may be denied access to health due to their ethnicity, language or another form of group membership. Sexual violence, poor sanitation and poor nutrition may lead to serious and life-threatening reproductive health complications. ${ }^{101}$

\subsection{Long-Term Health Impairment}

The denial of access to health, especially gynecological health, which, in the context of food shortages, sexual violence and the spread of HIV, constitutes an element of conflict that thus far, has not been recognized as a specific, justiciable violation. Other forms of ill-health affecting women specifically caused by conflict include: vesico-vaginal fistula; urinary tract infections; other uterine problems; scarring of the vagina; compromised reproductive health due to non-medical abortions or rape during pregnancy; de-normalization of all sexual activities; exacerbated pain in future childbirth; severe mental ill-health such as depression, trauma, post-traumatic stress disorder and suicide.

Domestic violence is also a major cause of ill-health for women and rises incrementally during and after conflicts, where violence becomes increasingly normalized. In addition, if DDR programs (Disarmament, Demobilisation and Reintegration) are not implemented, arms, if not removed after a conflict, may be used against women in domestic or intimate contexts.

These health risks are exacerbated by the lack of medical resources or the destruction of medical facilities during conflict and due to malnutrition. Gender roles may require an unequal distribution of food between men and women which, in times of conflict and food shortage, impairs women's immunity to disease and illhealth.

${ }^{101}$ In the Sierra Leone conflict, miscarriages were common among t so-called 'bush wives' or victims of forced marriage, who received limited or no medical attention. See Brima (Trial) (n 33) para 30 (Doherty J. dissenting). 
The deliberate infection of women with HIV AIDS or other sexually transmitted diseases is a more contemporary component of conflict that affects women specifically. Diseases may be spread as a result of the ability of combatants to command sexual services from women while moving from region to region. The movement of troops to different parts of the country and their ultimate return to their home areas after demobilization present significant risks to women. In Rwanda, women survivors of violence started to feel unwell. After a range of medical tests, many found that they are HIV positive:102 '[...] we saw that by 1999 many of the young girls who had been infected by HIV during the mass rape, were occupying the hospital beds, dying of AIDS-related diseases.' 103

\section{Deficiencies in post-conflict prosecutions}

Is it desirable to prosecute all these forms of gender-specific harm in post conflict contexts? Given the serious repercussions of criminal prosecutions, not all forms of harm - gendered or otherwise - should constitute violations of international criminal law. National criminal sanctions apply to particularly egregious acts of harm and this is even more applicable in the context of war crimes and international criminal law. It is these acts of harm against women that ought to fall within the rubric of international criminal law but which largely have been omitted due to historical silences.

\subsection{Conceptual Problems}

One of the key deficiencies in both international and national criminal justice mechanisms is the absence of criminal definitions that capture the specific harm women experience in war. With the exception of the ICTY, the ICTR and SCSL, international prosecutions rarely prosecuted acts of harm perpetrated against women during conflict. During conflicts, women are violated in a way that may not be prosecuted either because the harm is invisible in that it takes place in private or because the harm is systemic in that it forms part of a system of abuse. For these reasons the harm is deemed to fall outside the purview of the radar of judicial activity.

This has been addressed to some extent in cases of sexual violence. In Prosecutor $v$ Akayesu, the ICTR redefined the crime of rape as an act of aggression and not an act of sexual desire; ${ }^{104}$ sexual violence is not limited to invasion of human body

\footnotetext{
102 World Health Organization, 'Violence against Women Living in Situations of Armed Conflict', WHO report (October 2000), <http://www.who.dk/document/e74469.pdf > accessed 8 August 2011, page 8 .

103 Ibid.

104 The Tribunal stated: ' $[\ldots]$ that rape is a form of aggression and that the central elements of the crime of rape cannot be captured in a mechanical description of objects and body parts.'
} 
and it has been recognized that coercion need not manifest in physical force but includes threats, intimidation, extortion and 'other forms of duress which prey on fear or desperation. ${ }^{105}$ By combining the provisions of common Article 3 of the Geneva Conventions and Article 3 of the ICTY Statute, the ICTY established the requisite elements in order for certain conduct to constitute mass rape under international criminal law. Systematic and widespread rape was understood as a method to achieve ethnic cleansing and genocide; as the commission of a crime against humanity; and a war crime and that traditional notions of free will and consent must be assessed in the context of the surrounding circumstances. In Prosecutor v. Furundzija, ${ }^{106}$ the trial chamber held that 'any form of captivity vitiates consent.'107

The development of criminal concepts in respect of sexual violence should be seen as an example of how legal constructions may be broadened (without comprising the principles of non-retrospectivity) to include other acts of violence and forms of harm that women endure as a result of a deliberate war policy. It is necessary to redefine criminal categories to incorporate this nuanced and previously unrecognised harm. In the past, the laws and legal categories used by prosecutions have by-passed the factual harm committed against women in conflicts. It is therefore necessary to clarify the legal provisions to be applied to these identified forms of harm and the evidentiary amendments which might be required to allow for the submission of evidence.

The process of the criminalisation of forced marriage by the SLSC is informative. At the trial level, the majority of the Trial Chamber viewed forced marriage as a sexual crime which should be categorised as sexual slavery. It failed to engage the criminality of many other components of the crime of forced marriage. It was only on appeal that the Appeal Chamber ${ }^{108}$ embraced the broader notion of a 'forced conjugal association by the perpetrator over the victim. ${ }^{109}$

The most abusive aspect of a human rights injury may not be captured by the act alone but emerges from the range of social attitudes and policy frameworks within which the act is embedded. In the same way as genocide and ethnic cleansing comprise individual acts of harm in the context of a system of eradicating a people, the system of violence against women constitutes the crime as much as the individual acts of harm.

Legal reform and long term social change may compete for resources and national attention. Legal systems may be reformed to include acts of harm which

\footnotetext{
105 Ibid.

106 ICTY Prosecutor v Furundrija, Case No. IT-95-17/1-T (1998), 38 I.L.M. 317, 352-53.

107 Ibid para 271.See also the rules of procedure and evidence of the International Criminal Court which holds that consent cannot be inferred from the words or the acts of the victim when there is an oppressive or coercive context, or where the person is incapable of giving genuine consent, or by reasons of the silence or lack of resistance by the victim.

108 Brima (Appeal) (n 32).

109 This was a statement made by Justice Doherty in her dissenting judgment in Brima (Trial) (n 33) para 33.
} 
previously have been ignored, condoned or implicitly endorsed. Prosecuting acts of harm may influence the way society views certain conduct: conduct which is not prosecuted is perceived as legitimate or lawful; conduct which is prosecuted takes on a criminal - and therefore reprehensible - nature. However, legal reform is not an automatic panacea for harmful social perceptions and socio-psycho reform is also necessary. The broader challenge, however, is transforming a society's notion of what is normal to that which is abnormal.

\subsection{Procedural Problems}

The rules of procedure and evidence in criminal justice proceedings are notorious in estranging women victims and witnesses. At the level of international criminal justice, this is exacerbated by several factors. The first is that a tension exists for prosecutors between a legal victory and tough cases. Often prosecutors choose to pursue cases which will ensure a conviction (such as killings which are easier to prove if there is forensic evidence) rather than so-called 'tough cases' which, in the case of gender-crimes, are often without precedent and are therefore more risky. Gender-specific criminal cases often lack evidence and pursuing gender-justice has been seen as a form of 'rocking the boat.' Such contention may dissuade a prosecutor to use her/his discretion to pursue tough cases. This is exacerbated by the absence of a comprehensive strategy for the prosecution of crimes relating to women and sexual violence. ${ }^{110}$

There is often a lack of consultation with affected groups by prosecuting authorities and oftentimes improperly trained officers of criminal tribunals may alienate categories of victims, removing an important source of oral evidence and, ultimately, precluding victims' access to justice. Prosecutorial authorities should ensure a responsible prosecutorial mandate by consulting with stakeholders such as victims' groups and women NGOs or local organizations. Prosecutions often fail to reach out to marginalized, minority or subjugated groups to encourage testimony. Outreach is particularly necessary where women's experiences are deemed to be too intimate or humiliating for public discussion. The humiliation may dissuade women from testifying and publicizing their harm, for fear of public judgment. More poignantly, individuals often do not recognize their experiences as political

110 Binaifer Nowrojee, 'Your Justice Is Too Slow': Will the ICTR Fail Rwanda's Rape Victims? (United Nations Research Institute for Social Development, Occasional Paper 10, 2005). Nowrojee notes that No rape charges were even brought by the Prosecutor's Office in 70 per cent of those adjudicated cases. In the 30 per cent that included rape charges, only 10 per cent were found guilty for their role in the widespread sexual violence. Double that number, 20 per cent, were acquitted because the court found that the prosecutor did not properly present the evidence beyond a reasonable doubt. In real numbers, that means that, at the tenth anniversary of the genocide, only two defendants had specifically been held responsible for their role in sexual violence crimes (a third conviction was reversed on appeal), despite the tens of thousands of rapes committed during the genocide. As of April 2004, none of the rape acquittals had been appealed by the prosecutor. How can this be? 
due to the normalization of such harm, such as bodily violence, economic disempowerment or family loss. It is also important to research the conditions surrounding the relevant acts of harm, especially as regards patterns of abuse, such as repeated harm or abuse which operates on a continuum without a discernable end. ${ }^{111}$ This is particularly important for encouraging women to testify to their own harm, as opposed to others which they witnessed.

Only through consultation with victims can a prosecutorial entity know what the priorities and needs of the victim community are. The first stage is to identify the experiences and needs of women survivors of the conflict. Adequate local consultation is essential. Prosecution authorities may omit certain groups of victims as a result of inadequate local consultation. It really is only through consultation with local organizations, many of which have been present during the conflict or period of unrest, that prosecutorial entities can understand the patterns of abuse and interests of the communities. In order to obtain statements and investigate atrocities it is necessary to gain the trust of those affected by the conflict. ${ }^{112}$

Communication is central to respectful relationships with the victims and witnesses. A balance should be struck by the prosecutorial entity between retaining autonomy and independence while being accessible and transparent. It is also important to understand the needs - both financial and emotional - of the victims and witnesses who testify. For example, prosecutors should be sensitive to the responsibilities of the witness, her/his daily commitments and financial constraints, and her/his needs to retain anonymity, particularly in cases of sexual violence.

Tensions may arise between the goals of transitional justice and prosecutorial objectives. Addressing past injustices is critical to shaping the terrain for women's and men's struggles for justice now and in the future. Often, however, there is inadequate attention to the intersection between judicial victories and other goals of transitional justice, such as truth, reparations, memorialisation and national healing.

Where gender prosecutions are undertaken, if a prosecution is unsuccessful, the victim's suffering may be augmented by the legal finding that her perpetrator is innocent. Even if a prosecution is successful, it may not lead to the restoration of the victim's loss if the prosecution fails to take her well-being into account.It is necessary to ensure that the prosecutorial priorities coincide with the broader social goals and justice struggles that the prosecutions seek to support and advance.

\footnotetext{
111 Oosterveld (n 9) 415.

112 The Sierra Leone Truth Commission report proposes the following methodology in statementtaking: 'In summary, these guidelines directed statement-takers to ensure the following conditions:

i. That statement-taking should always be on a one-to-one basis;

ii. That the presence of husbands and fathers should be discouraged during statement taking, unless insisted upon by the statement-giver; and

iii. That as a rule of thumb, when dealing issues of rape and sexual violence, female statement takers should take the statements.
}

This policy did not preclude a preference being expressed by statement-giver that she was willing to make her statement to a male statement-taker.' Sierra Leone TRC Report (n 55) para 20. 
Due to the official nature of legal institutions, prosecutions can provide official public recognition and condemnation of women's human rights abuses. Therefore, within the broader contexts of transitional justice, the prosecution of violations against women demonstrates that there are consequences for conduct which previously, may have fallen below the judicial radar.

\subsection{Investigative activities}

\subsubsection{Sensitivity in Interviewing}

The manner in which a witness or victim is interviewed may have repercussions both for the individual and the success of the case. One of the weakest elements of recent prosecutorial efforts has been the alienation of victims as a result of a dearth of expertise. Legal and investigative teams often lack sufficient expertise in different aspects of gender and abusive systems. The lack of experience and alienating investigative techniques may dissuade victims and witnesses from engaging with prosecutors and investigators and, more importantly, can exacerbate the harm experienced by the victim. The sensitivity of statement-takers and investigators, therefore, is seminal. Investigators who interact with witnesses and victims need to understand the nuances and extraordinary emotional complexities involved. A failure to understand this, irrespective of one's gender, can alienate, irreparably, a victim or witness from the prosecution process.

\subsubsection{Managing Expectations}

It is also important to manage women's expectations regarding the way in which witness statements are used, the possible outcomes of the prosecution and the potential that the perpetrator may enter into a plea bargain with the prosecution. ${ }^{113}$

Post-conflict prosecutions generally take place in a highly-politicized environment and the prosecution of individuals may trigger hostilities or concerns regarding impartiality. Local populations generally require a comprehensive explanation of the approach of the prosecutions, the objective they hope to achieve and the rationale for utilizing resources to prosecute one individual, such as a commander, as opposed to another, such as a foot soldier. This is relevant in respect of systemic crimes, which involve the prosecution of high profile individuals who may not be guilty of individual acts of harm. This may frustrate victims whose direct tormentors are unpunished. This is of particular relevance to victims of sexual violence who may be frustrated that the individual rapist or torturer is not held responsible for her/his actions.Therefore, it is important that victims understand

${ }^{113}$ For a discussion of the difficulties of plea bargaining in respect of sexual violence see NikolicRistanovic (n 10) 288-9. 
prosecutorial strategies and the reasons why they have been selected to produce the evidence in question.

This can be achieved by engaging with victims regarding their expectations of justice. It is also necessary to inform stakeholders of realistic time periods and potential outcomes that could be expected from the prosecutions.

Finally, it is important to explain that prosecutions may yield a not-guilty verdict, which could upset both individual victims and violated communities, especially where the procedural values of a fair trial, standards of proof and the rights of the accused have not been discussed.

\subsection{The Trial: Modify rules of procedure and evidence}

Traditional evidentiary constraints and rules of procedure often make it difficult to prosecute gender-based harm. ${ }^{114}$ Acts of harm against women, such as rape, enforced impregnation, forced sterilization, and displacement, often leave no physical scars, are difficult to prove and rely on individual testimony. Traditional institutions and use of forensic evidence often are not appropriate to prosecute genderharm. Forensic evidence may be difficult to obtain after long periods of time and standards of proof and the corroboration of evidence might be difficult to obtain with reference to crimes committed in private. ${ }^{115}$

The jurisprudence and rules of procedure of the ad hoc tribunals and the ICC have led to important developments in the trial of sex-specific crimes, which should be replicated at the domestic level in incorporating the provisions of the Rome Statute.

Prosecutions should expand the rules of evidence, while ensuring that the rights of the accused are protected and due process sustained. It is important that the rules of evidence are practicable. The rules of evidence should be re-examined to ensure that they do not operate unfairly to exclude important evidence regarding marginalized crimes. This is not to discount the importance of the rights of the accused. However, a balance must be struck between the rights of the accused, on the one hand, and proper access to justice for the victims of gender-based violence, on the other. ${ }^{116}$

Prosecutorial initiatives often are urgent because evidence may be lost, destroyed or probative value weakened with the passing of time. However, this depends on the type of evidence and the passage of time should be mitigated in the rules of evidence generated in respect of gender-specific violations. Note should be taken too of the fact that gendered crimes are often harder to prove and witnesses

\footnotetext{
114 These problems are discussed by Oosterveld (n 9) 410 and Chinkin (n 8) paras 32-34.

115 This was addressed by the ICTY Appeals Chamber, Prosecutor v Zejnil Delalic, Zdravko Mucic (aka "Pavo"), Hazim Delic and Esad Landzo (aka "Zenga") (hereinafter Celebici Case), Judgement (20 February 2001) IT-96-21-A, para 506.

116 Oosterveld (n 9) 410.
} 
are less likely to testify. ${ }^{117}$ This may delay the obtaining of sufficient evidence but this delay should be balanced against the specific nuances of gender crimes, for example the crime of forced marriage. If this is a matter our justice systems wish to address, cognisance must be taken of the time and sensitivity necessary to secure witnesses and evidence. ${ }^{118}$

In addition, after conflicts and social disruption, such evidence may be difficult, if not impossible, to find and gendered abuse can be so ingrained that it is not necessarily easy to track and verify. It is unlikely that investigators will find a military memo commandeering that a culture of machismo be developed that can be used to convict those responsible for creating a climate conducive to the abuse of women.

There are also specific evidentiary problems associated with crimes such as rape. Corroboration of witness testimony is difficult in intimate crimes. Moreover, as time passes, it becomes increasingly difficult to gather definitive evidence for crimes like rape or sexual violence. For example, the Women's Caucus for Gender Justice has long called for dropping the requirement (still prevalent in most jurisdictions) of demonstrated non-consent for a successful rape charge. They urge that courts should recognize that coercive circumstances are inconsistent with the possibility of consent; when there is duress, acquiescence does not constitute consent and certainly a women's prior sexual history is not relevant.

A number of rules have developed which address the difficulties faced by women giving evidence of rape and sexual violence: The first is the no corroboration rule, which provides that no corroboration is required of a victim's testimony about sexual assault. The Rules of Evidence and Procedure of the ICTY, ICTR and ICC all provide that there is no requirement to corroborative evidence of the victim's testimony. ${ }^{119}$ The tribunals also created a rule precluding evidence of a victim's prior sexual conduct from the hearings ${ }^{120}$ and this has been incorporated into the Rome Statute. ${ }^{121}$

117 ICTR, Akayesu (n 21) para 417, 455 regarding the difficulty many witnesses have in recounting their experiences and the effect of sexual violence trauma on memory. See also SCSL Appeals Chamber, Prosecutor v Fofana and Kondewa, Appeals Judgment (28 May 2008) SCSL-04-14-A sec. VII, paras 80-85 (Winter J noted that the trial court erred by failing to take into account that it is extremely difficult to obtain evidence of gender-based sexual violence). For a discussion of this balance see Oosterveld (n 9) 410-11.

118 Oosterveld (n 9) 410-11.

119 Rule 96 of the International Criminal Tribunal for the Former Yugoslavia Rules of Procedure and Evidence (12 July 2007) UN Doc IT/32/Rev.40 and International Criminal Tribunal for Rwanda Rules of Procedure and Evidence (15 June 2007) UN Doc ITR/3/Rev.1. Rule 70(d) of the ICC Rules of Procedure and Evidence adopted by the Assembly of State Parties, Rule 70 (2002) UN Doc ICCASP $/ 1 / 3$ provides that 'Credibility, character or predisposition to sexual availability of a victim or witness cannot be inferred by reason of the sexual nature of the prior or subsequent conduct of a victim or witness.' See Chinkin (n 8) para 32.

120 Ibid.

${ }^{121}$ Rule 71 of the ICC Rules of Procedure and Evidence (n 119) prevents a Chamber from admitting evidence of prior sexual or subsequent sexual conduct of a victim or a witness. 
Consent of the victim is not allowed as a defence if (i) the victim was subject to or threatened by violence or if $\mathrm{s} /$ he had reason to fear violence, duress, detention or psychological oppression; or (ii) the victim reasonably feared that if $\mathrm{s} / \mathrm{he}$ did not submit to the assault, another individual would be subjected to or threatened by violence, duress, detention or psychological oppression. ${ }^{122}$

\subsection{The Problem of Court Institutions}

The court itself is also responsible for providing institutional facilities to protect the victims' dignity and ensure the accessibility of the court to as many stakeholders as possible. The same provisions should apply in the domestic implementation of the Rome Statute.

\subsubsection{Support for Witnesses and Survivors of Sexual Violence}

Criminal justice traditionally has focused on two parties, the prosecuting authority and the accused. Increasingly international criminal justice is turning its attention to the role and protection of the victims and witnesses. This is especially relevant in cases involving gender-basedcrimes. Victims of sexual violence may find it extremely difficult to testify in criminal proceedings, where they will have to revive traumatic encounters which in turn trigger judgment and social approbation and, however incorrectly, feelings of shame and self-blame. ${ }^{123}$

Rule 16(1)(d) ICC Rules of Procedure and Evidence requires gender-sensitive measures to facilitate the participation of victims and survivors of sexual violence and Rule 17(2)(a)(iv) ICC Rules of Procedure and Evidence requires the Victims and Witnesses Unit to make available training in trauma and sexual violence. ${ }^{124}$

The prosecuting authority in any criminal justice system is responsible for the wellbeing and safety of its witnesses and complainants. When prosecuting sexual and gender-specific crimes, this onus is broader. Such crimes often induce psychological damage, leaving the survivors living in fear, isolation and the subject of reprisals. ${ }^{125}$ In addition, the emotional turmoil of 'reliving' the harm under exami-

\footnotetext{
122 Rule 70 of the ICC Rules of Procedure and Evidence (n 119): consent may not be inferred from a victim's words or conduct 'where force, threat of force, coercion or taking advantage of a coercive environment undermined the victim's ability to give voluntary and genuine consent' 'where the victim is incapable of giving genuine consent' or from the victim's silent or lack of resistance.

See Chinkin (n 8) para 33.

${ }^{123}$ Chinkin (n 8) para 34. See also Nikolic-Ristanovic (n 10) 286-7, describing in particular the trauma and re-trauma of the witness in Furundrija (n 98).

${ }_{124}$ Chinkin (n 8) para 34.

125 SCSL Pre-Trial Chamber, Prosecutor v Norman Fofana and Kondewa, Decision on Prosecution Request for Leave to Amend the Indictment (20 May 2004) Case No. SCSL-04-14-PT, Boutet Dissent, paras 26-33 (noting to continuum of sexual violence and the far reaching impact this has both on the individual and the community).
} 
nation, may recreate the trauma experienced by the witness. ${ }^{126}$ Caution in engaging such witnesses and ensuring their safety, both physical and psychological, are factors that must be embedded in the criminal justice system of the state wishing to implement the Rome Statute.

Prosecutions often ignore the long-term need to provide follow-up assistance and support for victims and witnesses. ${ }^{127}$ Victims may be reluctant to testify for fear of stigmatization or retaliation and the courts should provide a victim-friendly environment through support structures and community outreach.

In some cases, individual hearings can be structured innovatively to ensure witness privacy while still allowing public hearings. For example, women may be allowed to provide testimony with their faces covered and public broadcast of hearings may use distorted facial imagery. Incamera hearings, which have been incorporated into the Rules of the ICC, may also provide for private testimonies. ${ }^{128}$ These facilities may be the responsibility of a separate unit within the prosecution, such as a victim and witness protection unit, as is the case in the ICC. The ITCY granted protective measures to several Prosecution witnesses, including such measures as ordering that protective screens be erected in the courtroom; employing image altering devices to prevent certain witnesses from being identified by the public; ensuring that no information identifying witnesses testifying under a pseudonym be released to the public, and requiring that transcripts of closed session hearings be edited so as to prevent the release of information that could compromise a witness' safety. ${ }^{129}$

\footnotetext{
126 The ICTY adopted a relatively conservative approach to re-traumatisation as a basis for preventing the accused from seeing the witness in Prosecutor v Zejnil Delalic, Zdravko Mucic also known as "Pavo", Haz̧im Delic, Esad Landzo also known as "Zenga", Decision On The Motions By The Prosecution For Protective Measures For The Prosecution Witnesses Pseudonymed "B" Through To "M" (28 April 1997) IT-96-21-T, paras 66-68, noting that there was no evidence of re traumatization "other than the ipse dixit of the Prosecution. Re-traumatisation is essentially a medical, psychological condition which requires better proof than the evidence before us. The evidence before us does not support the claim that witness " $\mathrm{B}$ " is a vulnerable witness.'

127 Ibid.

128 Rule 72 ICC Rules of Procedure and Evidence(n 119) allows for in camera procedure to consider the relevance or admissibility of evidence.

${ }^{129}$ Caution in engaging such witnesses and ensuring their safety, both physical and psychological, are factors that must be embedded in the criminal justice system of the state wishing to implement the Rome Statute. See Decision On The Motions By The Prosecution For Protective Measures (n 126) paras 40-46, noting that testifying about sexual violence

can be a most difficult and humiliating experience for him. In this case the evidence is likely to concern another person who is not a witness. The Report at paragraph 108 makes specific mention of the need to protect victims and witnesses especially in cases of rape or sexual assault. The Trial Chamber has no hesitation whatsoever in granting to the Prosecution its request for a closed session hearing for the testimony of witness " $\mathrm{C}$ ".
} 


\subsubsection{Organisational Structure}

Prosecutorial authorities should ensure an infrastructure that meets the needs of women, including: provision for in camera hearings; gender units; gender training; and physical and psychological support for victims and witnesses.

The court itself can be established in a way that facilitates gender requirements. these include facilities for in camera hearings and experts on gender crimes. a witness protection unit should be established which should be responsible for the: protection of witnesses before and after testifying before the court; advising the court on the need to protect the identity of victims if there are deficient witness protection programs and if the circumstances for the witness are sufficiently dangerous to warrant the curbing of the accused's right to face her/his accuser;physical and psychological rehabilitation of survivors of violence after they have testified; and, assisting survivors deal with social stigmas, ostracizing behaviour and economic hardship as a result of the violation perpetrated against them. Psychosocial and medical support are necessary prior to, during and after testifying.

\subsubsection{Witness protection and victim support}

Protection and support for victims and witnesses ought to be provided by the prosecutorial entity both before and after testifying. Women may be reluctant to testify in formal court proceedings, especially where the proceedings are excessively formal and the nature of their violation intimate and personal. Many tribunals also fail to accommodate the practical difficulties female victims face in accessing the court, travelling to the court, getting time off work, and being relieved of domestic responsibilities such as child-care. The International Tribunal for Rwanda, for example, situated in Arusha rather than Rwanda, did not allocate funds to meet the travel and associated expenses of victims and witnesses. Unless NGOs contributed to the expenses, many victims were unable to testify.

It is necessary to balance the rights of accused with witness protection. A balance should be struck between reforming procedural impediments, on the one hand, and ensuring a standard of judicial due process to protect the rights of the accused. A balancing act is necessary to ensure that while the safety of the witness or victim is secured the procedural right of the accused to examine all witnesses against her/him is compromised as little as possible. For example, in the Celebici, the ITCY discussed the need for protection of the privacy of witnesses and the necessary balancing between such considerations and the general principle of public proceedings. Such evidence is specifically excluded by virtue of sub-Rule 96(iv) and it was on the basis of this provision that the Trial Chamber ordered the redaction from the public record of references made in open court to the prior sexual conduct of a Prosecution witness while testifying to a charge of sexual assault. ${ }^{130}$

${ }^{130}$ Decision On The Motions By The Prosecution For Protective Measures (n 126). 
Gender representation in judicial, prosecutorial and support staff is necessary and required by the Rome Statute. 131 Judges should be appointed according to gender representation and their capacity to be sensitive to gender-specific harm. This can make a decisive difference to the nature of the prosecution, for example, Judge Pillay of the ICTR directed the prosecution to incorporate sexual violence in the indictment against Akayesu. Judge Benito of the ICTY was deliberate and determined in her instance that the experience of women during the conflict in the former Yugoslavia should not be forgotten. ${ }^{132}$

Traditionally prosecutors and their staff, tend to have limited expertise in gender, and the nuanced and complex ways in which women are affected by conflict. Training, to the extent that it is provided, usually is limited to one initial training session at the commencement of the prosecutions and is not carried through for the full life of the prosecution. It is therefore necessary to employ skilled staff and to provide on-going training. Ideally, a gender legal consultant should be employed. This was a feature of the ICTY and is attributed as one of the reasons for the success of this tribunal in its judgments on sexual violence. Employment of staff with gender expertise e.g. domestic police forces trained in domestic violence and sexual abuse cases.

\subsubsection{Outreach and Dissemination of Judicial Findings}

While prosecutorial authorities should remain independent of all groups, including NGOs and civil society, the prosecution should reach out to its constituents to ensure that it's work is communicated, understood, and in accordance with the needs of the community in general and victims individually. Such entities can be utilized also to deliver post-prosecutorial services such as victim support or community facilities.

The judicial decisions may not be distributed to the locations of the victims or in the language of the victims. This deprives victims of their ownership of the truth, their suffering and their healing. It sends a message that the prosecution of their perpetrators was not for their sake but for the sake of legal and political ends.

\section{Conclusion: Potential of post-conflict prosecutions for woman}

In implementing the provisions of the Rome Statute, African states face the challenge of creating and sustaining criminal justice systems that meet the rules and aspirations of the ICC. These aspirations include the protection of women and the

\footnotetext{
131 Chinkin (n 8) para 35.

132 See Sheila Vèlez, 'Aegis Interview with Judge Elizabeth Odio Benito, Judge in Lubanga Trial' AEGIS (27 August 2009) <http://www.aegistrust.org/Campaigns-Policy-and-Research/lubangachronicle-interview-with-judge-elizabeth-odio-benito.html> accessed 8 August 2011.
} 
prosecution of gender-based crimes. Prosecutorial initiatives provide a space for the expansion of legal norms - within the confines of intellectual integrity and jurisprudential precedent - to include victims previously ignored, and to punish perpetrators previously exonerated. In many cases there are deficient legal categories to capture - and provide redress for - specific forms of harm endured by women. This is usually due to an invisibility shaped and enabled by social structures and ideologies, including discrimination embedded in the legal system.

The prosecution of gender-specific harm both addresses past abuses and establishes women as more powerful players with effective rights in the new society. In its most simple form, prosecutions offer female victims a mechanism of redress by holding perpetrators accountable for their crimes. Prosecutions may also contribute to the social disapprobation of violence against women and particularly sexual violence. The end-goals of prosecutions may reach beyond individual cases of redress and affect the safety of women in transitional societies. 


\title{
The African Union's decisions on the indictments of Al-Bashir and Gaddafi and their implications for the implementation of the Rome Statute by African States
}

\author{
Hendrik Johannes Lubbe*
}

\begin{abstract}
This paper critically evaluates the AU's decisions on the indictments of Al-Bashir and Gaddafi and investigates their implications for the implementation of the Rome Statue by African states. In both cases the AU refused to cooperate with the ICC. The AU's motivation for its decision not to cooperate in the Al-Bashir case was the Security Council's failure to act upon its deferral request in terms of article 16 of the Rome Statute. Based on an expert study, however, it is inferred that the $A U$ did not make proper use of article 16 and could also have relied on articles 17 and 53. The core of the AU's refusal to cooperate in the Al-Bashir case pertains to the issue of the personal immunity of serving heads of state. In this regard, the contention that the irrelevance of the personal immunity of serving heads of state before the ICC is a rule of customary international law is doubtful based on an investigation into the usus and opinio juris requirements. It is further unclear if the status of the irrelevance of such immunity has been elevated to that of a jus cogens norm or an obligation erga omnes. The supposed discrepancy between articles 27(2) and 98(1) of the Rome Statute is evaluated and the argument that these articles should rather be read
\end{abstract}

\footnotetext{
* A previous version of this paper was presented at the first annual meeting of the African Expert Study Group on International Criminal Law (established under the auspices of the KonradAdenauer-Stiftung in 2010) held from 23 to 26 September 2011 in Brussels. This paper has also been presented for publication to the Potchefstroom Electronic Law Journal ISSN 1727-3781.
} 
together to complement one another is found to be convincingly made. Against this background, it is established that the AU's decision on the indictment of Al-Bashir is not in compliance with the Rome Statute and customary international law. Critique levelled against this decision probably influenced the AU's decision on the indictment of Gaddafi in that no reference was made to immunity. This paper further demonstrates that both of the AU's decisions persuaded some African states to unlawfully disregard the ICC's requests for cooperation. Finally, it identifies the risk that the AU's decisions could discourage those African states that are not States parties to the Rome Statute from ratifying and implementing the Statute, and that it could encourage African states that are States parties to withdraw.

\section{Les decisions de l'Union Africaine sur les actes d'accusation d'Al-Bashir et Kadhafi et leurs implica- tions pour la mise en ouvre du Statut de Rome par les États de l'Afrique}

\section{Résumé}

Cet article évalue de façon critique les décisions de l'UA sur les actes d'accusation d'Al-Bashir et Kadhafi et examine leurs implications pour la mise en cuvre du Statut de Rome par les États africains. Dans les deux cas l'U A a refusé de coopérer avec la CPI. La motivation de l'UA pour sa décision de ne pas coopérer dans l'affaire Al-Bashir fut l'échec du Conseil de sécurité à agir à sa demande de report des termes de l'article 16 du Statut de Rome. Basé sur une étude d'experts, cependant, on en déduit que l'UA n'a pas fait bon usage de l'article 16 et aurait aussi pu s'appuyer sur les articles 17 et 53. La raison du refus de l'UA à coopérer dans l'affaire AlBashir a trait à la question de l'immunité personnelle des chefs d'Etat en exercice. À cet égard, l'affirmation selon laquelle la non-pertinence de l'immunité personnelle des chefs d'Etat en exercice devant la CPI est une règle de droit international coutumier est douteuse sur la base d'une enquête des exigences du usus et opinio juris. Il est en outre difficile de savoir si le statut de la nonpertinence d'une telle immunité a été élevé à celui d'une norme jus cogens ou d'une obligation erga omnes. La différence supposé entre les articles 27 (2) et 98 (1) du Statut de Rome est évalué et l'argument selon lequel ces articles devraient plutôt être lu conjointement afin de se compléter se trouve être convaincant. Dans ce contexte, il est établi que la décision de l'UA sur l'acte d'accusation d'Al-Bashir n'est pas en conformité avec le Statut de Rome et le droit international coutumier. Les critiques portées contre cette décision ont probablement influencé la décision de l'UA sur la mise en accusation de Kadhafi dans le fait qu'aucune référence n'a été faite à l'immunité. Ce document démontre également que les deux décisions de l'UA ont convaincu certains États africains de rejeter illégalement les demandes de la CPI de coopération. Enfin, il 
identifie le risque que les décisions de l'UA pourraient décourager les États africains qui ne sont pas des États parties au Statut de Rome de ratifier et mettre en cuvre le Statut, et que cela pourrait encourager les États africains qui sont des États parties à se retirer.

\section{Introduction}

The establishment of the International Criminal Court (ICC) can be described as a significant achievement in the fight against impunity and, as a consequence, in strengthening the rule of law. Recent developments have, however, sparked severe points of criticism, which include the suggestion that the ICC is a hegemonic tool of western powers, that Africa is being targeted or being discriminated against, that Africa's efforts to solve its problems are being undermined, and that African calls for peace to be respected over justice are being ignored. It is said that these factors and the taking of action over Sudan and not over Gaza, for instance, are clearly signs of the operation of double standards. Furthermore, it is averred that there is a discrepancy between articles 27 and 98 of the Rome Statute ${ }^{1}$ concerning the customary international law rule relating to the immunity of heads of state. ${ }^{2}$

To date, 32 of the 54 African states are signatories to the Rome Statute, but only five of these states, namely Burkina Faso, Kenya, Senegal, South Africa and Uganda, have passed legislation to implement the Statute. It is notable that all of the cases currently before the ICC emanate from conflicts in African states. In a few of these cases, the serving head of state is charged for allegedly having committed international crimes. Some of these African states are not democracies and as a result the serving heads of state cling to power in an attempt to escape prosecution by relying on personal immunity due to the offices they hold. The situation in Libya prior to Gaddafi's death served as the most recent example of this.

The United Nations Security Council (the Security Council/UNSC), through the unanimous adoption of Resolution 1970 on 26 February 2011, referred the situation in Libya to the ICC and decided, under Chapter VII of the Charter of the United Nations $^{3}$ (the UN Charter), that 'the Libyan authorities shall cooperate fully with and provide any necessary assistance to the Court and the Prosecutor pursuant to this resolution'. ${ }^{4}$ The ICC Prosecutor subsequently opened an investigation that led to the issuing of three arrest warrants by Pre-Trial Chamber I of the ICC on 27 June 2011 respectively for Muammar Mohammed Abu Minyar Gaddafi, Saif

\footnotetext{
${ }^{1}$ Rome Statute of the International Criminal Court, 2187 UNTS 90, 17 July 1998, entered into force 1 July 2002 (Rome Statute).

2 Max du Plessis, The International Criminal Court that Africa wants (Institute for Security Studies 2010) vii and viii.

${ }^{3}$ Charter of the United Nations, 1 UNTS XVI, 26 June 1946, entered into force 24 October 1945.

${ }^{4}$ UNSC Res. 1970 (2011), 26 February 2011, S/RES/1970, para 5.
} 
Al-Islam Gaddafi and Abdullah Al-Senussi, for crimes against humanity, including murder and persecution allegedly committed across Libya from 15 February 2011 until at least 28 February 2011, through the State apparatus and Security Forces, in an attempt to put down a months-long revolt. ${ }^{5}$

It was the first time the ICC had taken action during an on-going conflict and the second time this Court had issued an arrest warrant for a serving head of state. In 2009 the ICC indicted Omar Hassan Ahmad Al-Bashir, the President of Sudan (as he was before South Sudan became an independent state), who has not yet been arrested. 6 This came after the Security Council, for the first time on 31 March 2005, invoked its extraordinary power under article 13(b) of the Rome Statute of the ICC (the Rome Statute), by referring the conflict in Darfur, Sudan, to the ICC by adopting resolution 1593. ${ }^{7}$ The fact that Al-Bashir is still at large can be ascribed partly to the AU's and various African states' refusal to cooperate with the $\mathrm{ICC}^{8}$ and the concern prior to Gaddafi's death was that he would similarly evade the ICC.

The significance of this paper lies in the fact that it focuses on the only two instances where the Security Council has referred situations to the ICC, one during an ongoing conflict, and both involving sitting heads of state. Although Gaddafi's death halted his prosecution, the standpoint the AU took on his indictment remains relevant. This is because it confirms the renewed troublesome relationship between the AU and the ICC, which remains a pressing issue. For that reason this paper critically evaluates the AU's decisions on the indictments of Al-Bashir and Gaddafi and investigates their implications for the implementation of the Rome Statute by African states.

The first section of this paper concerns the AU's decision on the indictment of Al-Bashir. The motivation given by the AU for its decision not to cooperate with the ICC was the Security Council's failure to act upon its deferral request in terms of article 16 of the Rome Statute. Recommendations made in 'An expert study on the African Union concerns about article 16 of the Rome Statute of the ICC'9

5 ICC Pre-Trial Chamber I, The Prosecutor v Muammar Mohammed Abu Minyar Gaddafi, Saif Al-Isalm Gaddafi and Abdullah Al-Senussi, Decision on the "Prosecutor's Application Pursuant to Article 58 as to Muammar Mohammed Abu Minyar Gaddafi, Saif Al-Islam Gaddafi and Abdullah Al-Senussi” (27 June 2011) ICC-01/11-12.

${ }^{6}$ ICC Pre-Trial Chamber I, The Prosecutor v Al Bashir, Decision on the 'Prosecution's Application for a Warrant of Arrest against Omar Hassan Al Bashir' (4 March 2009) ICC-02/05-01/09-3, and ICC PreTrial Chamber I, Prosecutor v Al Bashir, Second Decision on the 'Prosecution's Application for a Warrant of Arrest' (12 July 2010) ICC-02/05-01/09-94.

7 UNSC Res. 1593(2005), 31 March 2005, S/RES/1593 para 1. It is noteworthy that Sudan stands as the only non-party to the Rome Statute that is currently subject to ICC jurisdiction.

${ }^{8} \mathrm{It}$ is not only African states that refuse to cooperate. Some member states of the EU stated in similar vein that their implementation legislation would not allow them to arrest and surrender Al-Bashir to stand trial in the ICC. Denmark invited Al-Bashir to the international conference on climate change that was held in Copenhagen in 2009.

${ }^{9}$ Dapo Akande and others, An African expert study on the African Union concerns about article 16 of the Rome Statute of the ICC (Institute for Security Studies 2010) 1-30. 
which 'seeks to articulate a clearer picture of the law and politics of article 16 deferrals within the context of the AU's repeated calls to the United Nations Security Council $[. . .]^{10}$ will be relied on to come to a better understanding of how proper use of article 16 and alternative procedures including articles 17 and 53 of the Rome Statute should be made.

The core of the AU's refusal to cooperate in the Al-Bashir case pertains to the issue of the personal immunity of serving heads of state and forms the bulk of this paper. In this regard, the contention that the irrelevance of the personal immunity of serving heads of state before the ICC is a rule of customary international law is evaluated. Articles 27(2) and 98(1) of the Rome Statute and the supposed discrepancy between these articles are then discussed, after which the argument that these articles should be read together to complement one another by distinguishing between member and non-member states is assessed.

Following the AU's decision not to cooperate with the ICC, some of its member states expressed their disagreement and those that are States parties to the Rome Statute undertook to uphold their obligations under the Statute notwithstanding. Conversely other AU member states abided by the AU's decision and those that are States parties to the Rome Statute even went so far as to disregard their obligations under the Statute by hosting Al-Bashir.

The second section of this paper deals with the AU's decision on the indictment of Gaddafi. This section benefits from the debate sparked by the indictment of Al-Bashir and the assessment thereof was particularly useful in scrutinising the situation in Libya and the responses thereto. The AU again decided not to cooperate with the ICC, but did not rely on the personal immunity of Gaddafi as a sitting head of state. Instead, the AU based its decision on the premise that the indictment seriously undermined its peace initiatives in Libya and brought another article 16 deferral request. The merits of the AU's assumption that deferring the Gaddafi prosecution was essential to the peace initiatives in Libya will then be highlighted.

This paper concludes by establishing that the AU's decision on the indictment of Al-Bashir is not in compliance with the Rome Statute and customary international law, which probably influenced its decision on the indictment of Gaddafi. It further demonstrates that both of the AU's decisions persuaded African states to unlawfully disregard the ICC's requests for cooperation. Finally, this paper identifies the risk that the AU's decisions could discourage those African states that are not States parties to the Rome Statute from ratifying and implementing the Statute, and that it could encourage African states that are States parties to withdraw.

10 Akande and others (n 9) 3. 


\section{The AU's decision on the indictment of Al-Bashir}

The Assembly of Heads of State, the AU's highest decision-making organ, directed all AU member states not to cooperate with the ICC in executing the request for the arrest and surrender of Al-Bashir. This decision was justified by relying among other things on the principles of sovereignty guaranteed under the UN Charter and the Constitutive Act of the African Union ${ }^{11}$ (AU Charter) and the supposed discrepancy between articles 27(2) and 98(1) of the Rome Statute.

The AU decided that:

$[\ldots]$ in view of the fact that the request by the African Union has never been acted upon, the AU Member States shall not cooperate pursuant to the provisions of Article 98 of the Rome Statute of the ICC relating to immunities, for the arrest and surrender of President Omar El Bashir of The Sudan[...]. ${ }^{12}$

The 'request' referred to in the AU's decision relates to its request to the Security Council to defer the Al-Bashir prosecution in terms of article 16 of the Rome Statute. This request was based on the conviction that the indictment of Al-Bashir seriously undermined the AU's role in the peace process and that it jeopardised its peace efforts in Darfur. This line of reasoning touches on one of the most controversial issues in international criminal justice, namely the debate surrounding the relationship between the search for peace and the demands for justice.

The failure of the Security Council to consider the AU's request led to tension between the AU, the UN (in particular the Security Council) and the ICC, which resulted in the refusal by the AU and several of its member states to cooperate with the ICC. This tension has been described as how ICC prosecutions may be reconciled with peace-making initiatives and the role and power of the Security Council in ICC business'. ${ }^{13}$ This ultimately led to a proposal made by the AU to amend article 16 to empower the UN General Assembly to act should the Security Council fail to decide on a deferral request after six months.

\subsection{Article 16 of the Rome Statute: Deferral of investigation or prosecution}

Article 16 requires the ICC to refrain from commencing or proceeding with an investigation or prosecution for a period of 12 months if the Security Council so

\footnotetext{
${ }^{11}$ Constitutive Act of the African Union, 11 July 2000, entered into force 26 May 2001.

12 African Union Assembly, Decision on the meeting of African States parties to the Rome Statute of the International Criminal Court (ICC), (3 July 2009) Assembly/AU/Dec.245 (XIII) Rev. 1 Doc. Assembly/AU/13(XIII), p. 2 para 10 (emphasis added).

13 Akande and others (n 9) 3.
} 
requests in a resolution adopted under Chapter VII of the UN Charter. ${ }^{14}$ This has been described by some as one way in which the tension between the search for peace and the demands for justice may be mediated, in that this article accepts that there may be circumstances where the demands of peace, at least temporarily, require or permit the suspension of an investigation or prosecution by the ICC. ${ }^{15}$

In reaction to the adoption of resolution 1487 at the Security Council's 4772nd meeting, several states voiced their concern about the nature and scope of article 16. The Netherlands, with Germany and Canada concurring, held that article 16 '[...] allows deferrals - only on a case by case basis; - only for a limited period of time; - and only when a threat to or breach of peace and security has been established by the Council under Chapter VII of the UN Charter'. ${ }^{16}$

There are concerns regarding the AU's proposed amendment to article 16, but they will not be dealt with here. ${ }^{17}$ Even if these concerns could be addressed properly, an amendment seems unlikely in the case of the AU's proposal. This is so because article 121(4) of the Rome Statute sets a high threshold (ratification by seven-eighths of the States parties to the Statute), and considering the lack of support from non-African States parties following South Africa's presentation of the proposal at the 8th session of the ICC Assembly of States Parties, and the limited formal support shown by African States parties themselves. ${ }^{18}$ Therefore it seems practical, for the time being at least, to make use of existing procedures and structures the Rome Statute provides for, such as articles 16, 17 and 53. The following recommendations were made in the expert study. ${ }^{19}$

The first recommendation is that 'ICC States parties (especially from Africa) should work towards increased and deeper engagement between the AU, the UNSC, and the ICC, including the ASP'. ${ }^{20}$ The necessity for greater dialogue and consensus building among African States parties (within and outside the forum of the $\mathrm{AU}$ ) was therefore identified and it was advised that:

a) dialogue should proceed on the basis of a proper understanding of the law;

b) those states supporting the deferral need to clearly set out those factors which in their opinion weigh in favour of a deferral;

c) it should be shown how a deferral of a prosecution would advance the cause of peace and security;

\footnotetext{
${ }^{14}$ In practice, this effectively means that a deferral will require the approval of nine of the 15 Security Council members and the lack of an opposing vote by any of the five permanent members.

15 Akande and others (n 9) 5.

${ }^{16}$ UNSC, 58th Session, 4772nd Meeting (12 June 2003) S/PV.4772, 20.

${ }^{17}$ For a thorough discussion of these, see Akande and others (n 9).

18 Akande and others (n 9) 16.

${ }_{19}$ Akande and others (n 9) 1-30.

${ }^{20}$ Akande and others (n 9) 22-23.
} 
d) it is incumbent to timeously use all existing Security Council procedures so as to ensure that the arguments regarding deferrals are heard and considered;

e) this will require carefully planned and proactive lobbying well in advance of relevant meetings and intergovernmental processes to build support for their request among Security Council countries;

f) continental leaders should call for the establishment of the liaison office and the conclusion of a formal cooperation agreement between the $\mathrm{AU}$ and the ICC; and

g) African ICC States parties may also consider calling on the AU to extend an invitation to the ICC to attend sessions of the AU Assembly.

Secondly, the expert study recommends that '[a]ffected states and intergovernmental organisations seeking a deferral under article 16 should make a reasoned case for such a deferral using all relevant UN procedures'. ${ }^{21}$ According to the expert study, making out a 'reasoned case' includes that States parties should:

h) make calls for a deferral under article 16 only on the basis of a proper assessment of the publicly available evidence and in a manner that respects the internal processes of the Rome Statute to which they are a party;

i) demonstrate that continuing ICC investigations and prosecutions will constitute a bigger impediment or threat to peace and security than deferring the proceedings;

j) engage fully with key actors within the UN; and

k) present credible evidence to the Security Council in a timely manner in accordance with the rules of procedure and other relevant protocols of the Security Council.

The third recommendation is that

$[w]$ here credible alternative justice mechanisms exist, affected states and relevant intergovernmental organisations should call for appropriate use of relevant aspects of article 53 of the Rome Statute to ensure that the broader interests of justice are upheld. ${ }^{22}$

The expert study noted that under article 53(1)(c) and 53(2)(c) of the Rome Statute, the prosecutor (subject to approval by the ICC's Pre-Trial Chamber) may decide not to proceed with an investigation or prosecution where such an action would not serve the 'interests of justice'. According to the expert study this could 
be where a state in transition from conflict has established credible alternative mechanisms aimed at achieving the twin goals of restorative justice and reconciliation, for example a truth and reconciliation process. In this case it is advised that the ICC prosecutor should be invited by relevant states and intergovernmental organisations to consider whether or not the continuation of investigations or prosecutions before the ICC would be in the interests of justice.

Finally, the expert study recommends that '[s]tates should expand the use of domestic prosecutions of those accused of ICC crimes'. ${ }^{23}$ For this purpose article 17 of the Rome Statute was proposed. This article embodies the principle of complementarity, which permits a state (even a non-party to the Rome Statute) that has jurisdiction over a crime that is the subject of proceedings before the ICC to raise an objection to the admissibility of a case on the grounds that the state is willing and able to prosecute the crime. In such a case the expert study highlighted that the ICC, unlike the Security Council, has an obligation to reach a reasoned decision on those questions in the case of a deferral.

From the recommendations made in the expert study in response to the way in which the AU dealt with the article 16 request for deferral in the Sudan case, the inference can be drawn that the AU did not properly make use of the article 16 procedure and did not consider the use of other existing avenues such as articles 17 and 53 , which could have led to the ICC postponing prosecutions.

It is difficult, however, to imagine the Security Council deferring a situation under Chapter VII of the UN Charter when it has referred the situation under the very same Chapter. A well-informed, compelling and reasoned case would have to be made by the state requesting a deferral under article 16 . The chances of success would indeed be better if the requesting state were to follow the recommendations described above rather than if these were not followed, assuming that the Security Council and the ICC also 'came to the party'.

\subsection{The personal immunity of serving heads of state: Customary international law and the relationship between articles 27(2) and 98(1) of the Rome Statute}

This section now turns to the core of the AU's decision, namely the refusal to cooperate ' $[\ldots]$ pursuant to the provisions of Article 98 of the Rome Statute of the ICC relating to immunities[...]'. This section focuses on personal immunity 'ratione personae', which applies to certain state officials only, attaches to a particular office and is held only as long as the particular official is in office. Furthermore, it specifically deals with the question of whether or not the customary rule of international law on the personal immunity of serving heads of state, which prevents a domestic

${ }^{23}$ Akande and others (n 9) 24. 
judicial authority from issuing an arrest warrant against such individuals, ${ }^{24}$ applies equally to an international forum such as the ICC.

The constitutive instruments of various international tribunals ${ }^{25}$ and particularly the Rome Statute expressly stipulate that no immunity shall attach to serving heads of state. Article 27(2), on the irrelevance of official capacity in the exercise of its jurisdiction by the ICC, determines that immunities shall in no case exempt a person from criminal responsibility and shall not bar the Court from exercising its jurisdiction over such a person. This section of the Statute clearly limits its applicability to cases related to the exercise of jurisdiction by the Court and therefore the Statute derogates from the customary international rule on personal immunity among contracting states only. ${ }^{26}$ Furthermore, it is important to bear in mind that the ICC was established by a treaty and that only parties to this treaty are bound by its provisions. ${ }^{27}$ It therefore follows that article 27(2) cannot remove immunities that international law grants to officials of states that are not party to the Rome Statute. 28

The situation with states that are not parties to the Rome Statue is, however, less straightforward, and one may have to look beyond the Statute for a solution. Some make the bold statement that the irrelevance of the rule on personal immunity, national and international, for the exercise of jurisdiction by any international criminal court is a rule of customary international law. ${ }^{29}$ According to those in support of this statement, it is clear from case law that the rules of customary international law on the personal immunity of serving heads of state do not apply in the case of the exercise of criminal jurisdiction by an international criminal court. Cases cited include the Pinochet Case, the Arrest Warrant Case, ${ }^{30}$ and the case against Charles Taylor. ${ }^{31}$ In the latter case, the Appeals Chamber of the Special Court for Sierra Leone, for example, noted that the principle of sovereign immunity 'derives from the equality of sovereign states and therefore has no relevance to internation-

\footnotetext{
${ }^{24}$ In the Pinochet cases the House of Lords accepted that incumbent heads of state retain absolute personal immunity on account of their status (ratione personae). See $\mathrm{R} v$ Bow St Magistrate, Ex Parte Pinochet Ugarte 19984 All ER 938 and R v Bow St Magistrate, Ex Parte Pinochet (No 3) 19992 WLR 824 $905 \mathrm{H}$. This was affirmed by the International Court of Justice in the Arrest Warrant case, see Democratic Republic of the Congo v Belgium 2002 ICJ Reports 3.

${ }^{25}$ Compare article 7 of the Nuremberg Charter, the statutes of the ad hoc tribunals for the former Yugoslavia (ICTY) [article 7(2)] and Rwanda (ICTR) [article 6(2)], and article 6(2) of the Statute of the Special Court for Sierra Leone.

26 Paola Gaeta, 'Does President Al Bashir Enjoy Immunity from Arrest?' (2009) 7 Journal of International Criminal Justice 322, 325 and 329.

27 Article 26 and 34 of the Vienna Convention on the Law of Treaties, 1155 UNTS 331 (1969), 23 May 1969, entered into force 27 January 1980.

${ }^{28}$ Dapo Akande, 'International Law Immunities and the International Criminal Court' (2004) 98(3) American Journal of International Law417.

${ }^{29}$ Gaeta (n 26).

${ }^{30}$ For full references to these cases, see n 24 above.

31 SCSL Appeals Chamber, Prosecutor v Taylor, Decision on Immunity from Jurisdiction, SCSL-200301-I-059 (31 May 2004).
} 
al criminal tribunals which are not organs of a state but derive their mandate from the international community'. 32

If the above is accepted, one is tempted to go a step further and argue, as others have, that the principle enshrined in article 27(2) merely codifies an 'existing principle of customary international law', namely the irrelevance of the rule on personal immunity (national and international) for the exercise of jurisdiction by any international criminal court, which consequently applies with respect to every person regardless of whether or not the state this person represents is party to the Rome Statute. ${ }^{33}$

This warrants a closer look at how a rule of customary international law comes into existence and, based on this investigation, at whether or not the statement that the irrelevance of the rule on personal immunity is a rule of customary international law can be justified. It is trite that international law is based on consent and that the consent of states to a customary rule is inferred from their conduct, which raises difficult questions of proof. ${ }^{34}$ In this regard the two main requirements for the existence of a customary international rule should be considered, namely settled practice (usus) and the acceptance of an obligation to be bound (opinion juris). Based on the reaction to the indictment of Al-Bashir and Gaddafi by the AU and in particular several of its member states, it is doubtful whether pertaining to usus there can be mention of 'constant and uniform usage' or 'general acceptance', and as regards 'opinio juris' whether there is a sense of obligation or a feeling that these African states are bound by or have accepted the proposed 'rule' as law.

The relationship between usus and opinion juris causes further difficulty. The question is whether or not both of these requirements have to be met. Dugard states that 'settled practice on its own is insufficient' and that '[i]n addition there must be a sense of obligation [...]'. ${ }^{35}$ With regard to the creation of customary rules by the political organs of the UN, two cases illustrate the different approaches. On the one hand, the Filartiga case ${ }^{36}$ failed to make a thorough enquiry into state practice on torture, while the requirement of usus was put too high by the court in $S v$ Petane, ${ }^{37}$ which had to consider the question as to whether or not Additional Protocol I of 1977 to the Geneva Conventions of 1949 had become part of customary international law. ${ }^{38}$ According to Dugard, this is borne out by the Nicaragua case, ${ }^{39}$ in which the International Court of Justice (ICJ) was required to decide whether or not the prohibition on the use of force had acquired the additional status of a cus-

\footnotetext{
32 Ibid para 51.

33 Gaeta (n 26).

34 John Dugard, International Law: A South African Perspective (4th rev. ed Juta 2011) 26.

35 Dugard (n 34) 29.

36 Filartiga v Pena-Irala 630 F 2d 876 (2nd Cir 1980).

37 S $v$ Petane 19883 SA 51 (C).

38 Dugard (n 34) 27.

39 Nicaragua v US (Merits) 1986 ICJ Reports 14.
} 
tomary rule. ${ }^{40}$ He points out that the ICJ did not consider usus and holds that this could suggest that a customary rule may be established with little evidence of settled practice where opinion juris on the part of states is clear from their support. This debate is particularly interesting when it is applied to some African states that are quick to sign and ratify international instruments but are hesitant to give effect to these in practice.

Whether or not a dissenting state will be bound by the acceptance of a rule by other states is another point at issue. One view is that article 38(1)(b) of the Statute of the International Court of Justice 'does not exclude the possibility of a few dissidents for the purpose of the creation of a customary international law'. Another view supported by judicial and academic opinion is that a persistent objector cannot be bound. ${ }^{41}$ It follows that if there is no consent on the part of a particular African state pertaining to the disregard of personal immunity, that state cannot be bound.

Another question is if there are issues to which the normal rules relating to persistent objection are inapplicable. Does the irrelevance of personal immunity before an international forum have a peremptory and/or fundamental character (jus cogens) making it superior to ordinary norms, and from which no derogation is permitted? Do states owe an obligation (erga omnes) to the international community as a whole to disregard personal immunity before an international forum and in the enforcement of which all states have an interest?

This line of reasoning is based on the notion that the international community is 'glued together' by the international value system, that this community accepts the existence of particularly important superior values, and that it is capable of developing a legitimate hierarchical legal system. ${ }^{42}$ With regard to jus cogens, however, what qualities elevate a norm to a hierarchically superior level remains controversial, ${ }^{43}$ and uncertainty exists over which norms qualify as peremptory. ${ }^{44}$ Similarly, it is difficult to establish how obligations erga omnes are identified. ${ }^{45}$

One could say that there are indications of a development in the value system within the international community pertaining to the irrelevance of personal immunity in the fight against impunity. These include the contention that conventions and custom prescribe a wide range of human rights obligations with which states must comply and that some human rights norms enjoy such a high status that their violation, even by state officials, constitutes international crimes, and that due to this and other recent developments, the doctrine of immunity is under pres-

\footnotetext{
40 Dugard (n 34) 32.

41 Dugard (n 34) 29.

42 See Erika de Wet, 'The International Constitutional Order' (2006) 55 International and Comparative Law Quarterly 51-76 and Jure Vidmar, 'Norm Conflicts and Hierarchy in International Law' in Erika de Wet and Jure Vidmar (eds), Hierarchy in International Law: The Place of Human Rights (Oxford University Press 2012) 13-41.

43 Vidmar (n 42) 13.

44 Dugard (n 34) 38.

45 Vidmar (n 42) 23.
} 
sure. ${ }^{46}$ Also it is no longer commonly accepted that sovereignty grants a head of state unrestricted power or unconditional authority to act at his own discretion and will shield him from individual criminal responsibility when his acts constitute international crimes. Contemporary international law no longer accepts that a state may treat its nationals as it pleases. Despite the afore-mentioned indications, it is not clear if the irrelevance of personal immunity has reached the status of jus cogens yet. Dugard states that international commerce, for example, has destroyed the absoluteness of state immunity in respect of commercial transactions, but cautiously notes that international human rights law and international criminal law are poised to weaken it still further'. He does not explicitly argue that the absoluteness of personal immunity has been destroyed by international human rights law and international criminal law and from the wording, he is clearly not convinced. ${ }^{47}$

This uncertainty could have been the motivation behind article 98(1) of the Rome Statute. This article determines that the ICC is blocked from proceeding with a request for surrender or assistance which would require the requested State to act inconsistently with its obligations under international law with respect to the immunity of a person or property of a third State unless a waiver of such immunity from the third state can first be obtained by the ICC. The rationale for the inclusion of article 98(1) could be that it preserves the applicability of the customary international law rule on personal immunity in cases where non-States parties are involved, if 'third state' is to be interpreted as a non-State party. Article 98(1) would thus apply with respect to officials whose state has not waived their immunity through article 27(2), thus requiring the ICC to seek a waiver in terms of section 98(1) with respect to such an official. ${ }^{48}$ If 'third state' is, however, interpreted to include a State party, article 98(1) would allow States parties to rely on those immunities abolished by article 27(2) in order to prevent the surrender of their officials to the ICC by other states and consequently article 27(2) would be nullified in practice. ${ }^{49}$ Clearly this could not have been the intention of the drafters of the Rome Statute..$^{50}$ It therefore follows that the head of state of a State party cannot

\footnotetext{
46 Dugard (n 34) 250.

47 Dugard (n 34) 251.

${ }^{48}$ See Akande (n 28) 425 'To give meaningful effect to Article 27, Article 98(1) must be interpreted as applying only to officials of nonparties'. See also Paola Gaeta, 'Official Capacity and Immunities' in Antonio Cassese and others (eds), The Rome Statute of the International Criminal Court: A Commentary (Oxford University Press 2002) 993-994. According to Gaeta the problem can easily be solved if one construes the words 'third states' in article 98(1) as referring to non-contracting states, and not as 'third' in the sense of a state other than the requested state. Under this interpretation, she holds that a waiver of immunity is a necessary condition to the execution of a request for surrender only in those cases where the requested (contracting) state is internationally obliged to respect the immunities of states not party to the Statute.

49 Akande (n 28) 423-424.

${ }^{50}$ It appears that articles 27 and 98 were drafted by different committees, and it is thus not clear how much, if any, thought was given to their potential inconsistency. See Akande (n 28) 426 citing Otto Triffterer, 'Article 27' in Otto Triffterer (ed), Commentary on the Rome Statute of the International Criminal Court: Observers' notes, article by article (2nd ed Hart Publishing 2008) citing Per Saland, 'International
} 
claim immunity before the ICC due to article 27(2), but the head of state of a nonState party continues to hold such immunity. Since Al-Bashir is the head of state of a non-State party he would be immune under article 98.

Based on this seemingly logical explanation, it is contended by many that articles 27(2) and 98(1) may and should be interpreted to complement one another. ${ }^{51}$ This line of reasoning could also be seen as confirmation of the distinction between the exercise of the ICC's jurisdiction in terms of article 27(2) and the obligation on States parties to cooperate with the ICC in terms of article 98(1).

Pre-trial Chamber I of the ICC did not decide on the relationship between articles 27(2) and 98(1) in the Al-Bashir case, but '[...] appears to have considered that the President of Sudan did not benefit from any immunity at international law under the circumstances $[. .$.$] ' and that therefore ' [. .$.$] States parties would not find$ themselves confronted with conflicting obligations, and that consequently article 98(1) found no application'. ${ }^{52}$ The Chamber grounded its decision by referring to the purpose of the establishment of the ICC, namely that of putting an end to impunity. ${ }^{53}$ The Chamber then emphasised the 'core principle' embodied in article 2754 and did not rely upon rules of customary international law or rules derived from one of the other sources listed in article 21 of the Rome Statute, for the question of the official capacity of a person and of the immunities he or she may enjoy is regulated by article $27 .{ }^{55}$ The Chamber's last argument ${ }^{56}$ relates to another school of thought on the immunity (and lack thereof) of the head of state of a non-State party to the Rome Statute, that contends that all States that are bound by the UN Charter, including non-State parties to the Rome Statute, will in terms of article 25 of the UN Charter be bound by a Security Council decision to confer jurisdiction on the ICC, like the decision to refer the conflict in Darfur, Sudan, to the ICC by

criminal law principles' in Roy Lee (ed), The International Criminal Court: The making of the Rome Statute: Issues, negotiations, results (Kluwer Law International 1999) 189, 205 n 25 'Article 98(1) was not properly co-ordinated with Article 27 of the ICC Statute'. See also Johan van der Vyfer, 'Prosecuting President Omar Al Bashir in the International Criminal Court' 11,

<http://web.up.ac.za/sitefiles/file/47/15338/PDF\%20Files/Johan\%20van\%20der\% 20Vyver.pdf> accessed 28 June 2012, who adds that

[t]his should come as no surprise, since the two provisions were drafted by different working groups (Article 27 by the Working Group on General Principles of Criminal Law and Article 98 by the Working Group on Cooperation and Judicial Assistance), and given the time constraints under which the drafters had to complete their mandate in Rome, proper coordination of all the provisions in the ICC Statute was not always practically possible.

${ }^{51} \mathrm{Du}$ Plessis (n 2) 77.

52 William Schabas, The International Criminal Court: A commentary on the Rome Statute (Oxford University Press 2010) 1042.

53 ICC Pre-Trial Chamber I, Al Bashir (n 6) 42.

54 Ibid 43.

55 Ibid 44.

56 Ibid 45. 
adopting resolution $1593 .{ }^{57}$ Others, however, reject this approach and argue that a Security Council deferral does not and cannot turn a State non-party to the Statute into a State party, and fail to see how the fact that the jurisdiction of the ICC over the crimes in Darfur was triggered by the Security Council can make a treaty provision, namely article 27, applicable to Sudan, if this State has not accepted the regulation contained therein. ${ }^{58}$

The contention that articles 27(2) and 98(1) should be interpreted to complement one another does not appear to support the argument that article 27(2) merely codifies an 'existing customary international law principle' and that it consequently applies to every person enjoying immunity under customary international law. This is because if one accepts the codification argument, one could argue that customary international law has done away with immunity totally and that a waiver is therefore not even in question. An argument may then be made that article 98(1) no longer reflects the same sentiments that were considered more than a decade ago when the Rome Statute was drafted in 1998. Article 98(1) could therefore be regarded as redundant and should be amended. With regard to Africa, or certain of its states at least, one could also argue that article 98(1) still has relevance in view of political history and recent practices. Independence and sovereignty are relatively novel after colonialism ended roughly between 1950 and 1970. This might be why African states are reluctant to abandon certain aspects of their sovereignty in practice. This is evident from the concern expressed by the former chairperson of the AU, Binguwa Mutharika (former President of Malawi) at the July 2010 summit, that the issuing of an arrest warrant for a head of state is a violation of the principles of sovereignty guaranteed under the UN Charter and the AU Charter. ${ }^{59}$

As long as there is no decisive ruling by the ICC on the exact relationship between articles 27(2) and 98(1), or if the relevant part of article 98(1), which reads 'third State', is not going to be amended to read 'non-State party', the issue remains reduced to a matter of interpretation. This is problematic because the uncertainty will continue to be exploited by uncooperative States parties. This much is clear from the AU's reasoning at the Review Conference of the International Criminal Court held in Kampala, Uganda on 31 May to 11 June 2010 and the position taken by various African states, as discussed below.

\subsection{Responses by African states}

The AU's decision was directed at all of its member states and clearly aimed to bind all of its members. From a treaty law perspective a question arises regarding the possible conflict of obligations for those member states of the AU that are also

\footnotetext{
${ }^{57}$ For a discussion on this see Max du Plessis and Christopher Gevers, 'Making amend(ment)s: South Africa and the International Criminal Court from 2009 to 2010' (2009) 34 South African Yearbook of International Law 22.

58 See Gaeta (n 26) 324.

${ }^{59}$ Du Plessis (n 2) 18.
} 
States parties to the Rome Statute. The AU as a regional organisation is not a party to the Rome Statute, but some of its member states are, and these African ICC States parties' international obligations under the Rome Statute take precedence over collective decisions taken by the AU. This position was confirmed when Botswana, South Africa and Uganda, for example, declared that they disagreed with the terms of the AU's decision on the ICC's request for the arrest and surrender of Al-Bashir. These states held that they, as parties to the Rome Statute, are bound by article 27(2) as well as the corresponding provisions in their domestic laws that incorporate the Rome Statute and in terms of which they are obliged to disregard immunities. In all likelihood these and other states would have maintained their standpoint as regards the arrest warrant for Gaddafi issued by the ICC and the Security Council's request for his arrest and surrender. Perhaps, as an acknowledgement of this difficulty, the AU requested its member states 'to balance, where applicable, their obligations to the AU with their obligations to the ICC' in the Assembly's decision taken in Kampala.

Conversely, other States parties, like Kenya and Chad, abided by the AU's decision not to cooperate with the ICC and as a result failed to adhere to their waiver of immunity through article 27(2). Their subsequent noncompliance with their general obligation to cooperate fully with the ICC in its investigation and prosecution of crimes within its jurisdiction contained in article 86 and elaborated on in greater detail in the provisions of article 87 was referred to the Security Council by the ICC in terms of article 87(7). These states justified their position by referring to competing obligations toward the ICC, the AU, and regional peace and stability. No further action has been taken so far and the concern is that the inaction sends out a message that States parties' non-compliance goes unpunished.

\section{The AU's Decision on the Indictment of Gaddafi}

The concern that the discontent with issues related to the Al-Bashir case could have implications for future cooperation ${ }^{60}$ became a reality sooner than expected in that the AU's response to the indictment of Gaddafi mirrored the position it took on the Al-Bashir indictment. The AU similarly, but in a different vein, decided that African states should not cooperate with the ICC in executing the request for the arrest and surrender of Gaddafi.

As in the Al-Bashir case, the AU based its decision on the conviction that the warrant seriously undermined the AU's role as regional organisation in the prevention, management and resolution of conflicts, and that it complicated its efforts to negotiate a peaceful political settlement between Gaddafi's forces and Libyan rebels, that would end the conflict and solve the crisis in Libya. The AU expressed its deep concern:

\footnotetext{
${ }^{60}$ Akande and others (n 9) 5.
} 
[...] at the manner in which the ICC Prosecutor handles the situation in Libya which was referred to the ICC by the UN Security Council through Resolution 1970 (2011). The Assembly NOTES that the warrant of arrest issued by the Pre-Trial Chamber concerning Colonel Qadhafi, seriously complicates the efforts aimed at finding a negotiated political solution to the crisis in Libya, which will also address, in a mutually-reinforcing way, issues relating to impunity and reconciliation. In this regard, the Assembly DECIDES that Member States shall not cooperate in the execution of the arrest warrant, and REQUESTS the UN Security Council to activate the provisions of Article 16 of the Rome Statute with a view to deferring the ICC process on Libya, in the interest of Justice as well as peace in the country; ${ }^{61}$

On 17 March 2011, a week after the AU had adopted its Roadmap for the peaceful resolution of the Libyan conflict, the UN Security Council adopted Resolution $1973^{62}$ 'condemning the gross and systematic violation of human rights, including arbitrary detentions, enforced disappearances, torture and systematic executions'. ${ }^{63}$ The Resolution introduced active measures including a no-fly zone, and the authorisation to member states, acting as appropriate through regional organisations, to use 'all necessary measures' 64 to protect Libyan civilians. Speaking at the annual Dullah Omar Memorial Lecture at the University of the Western Cape on 16 February 2012,65 former President Thabo Mbeki argued that Resolution 1973 created space for the North Atlantic Treaty Organisation (NATO), an independent US-European military and political alliance, to intervene in Libya to impose a violent resolution of this conflict, centred on regime change, which objective was completely a variance with the objective of Resolution 1973. In essence, NATO intervened not to impose a no-fly-zone to protect civilians, as prescribed by the UN Security Council, but to lead and empower the opposition National Transitional Council in a military campaign to overthrow the Gaddafi regime. This much was made clear about a month after the adoption of Resolution 1973 when the US, Britain and France declared that military action against Libya would continue until Gaddafi was overthrown. The newspaper article reporting the attitudes of Barack

\footnotetext{
${ }^{61}$ African Union Assembly, Decision on the implementation of the assembly decisions on the International Criminal Court, (1 July 2011), Assembly/AU/Dec. 366(XVII), Doc. EX.CL/670 (XIX), para 6.

62 UNSC Res 1973 (2011) [on the situation in the Libyan Arab Jamahiriya], 17 March 2011, S/RES/1973(2011).

${ }^{63}$ Ibid p. 1

${ }^{64}$ Ibid para 4.

65 Thabo Mbeki, 'Reflections on Peacemaking, State Sovereignty and Democratic Governance in Africa' 1-16 <http://mg.co.za/uploads/2012/02/16/mbeki-speech.pdf> accessed 20 February 2012.
} 
Obama, David Cameron and Nicolas Sarkozy left no doubt that the Libyan leader had to go, making this a policy of regime change by another name. ${ }^{66}$

This caused tension between the AU and NATO. NATO interpreted Resolution 1973 widely to justify its actions, and the AU is strongly opposed to regime change under the auspices of intervention by the UN Security Council.

The President of the Republic of South Africa, Jacob Zuma, who leads the AU's ad hoc committee on Libya and who took a strong stance against the NATO air-strikes, raised concern over the issuing of the arrest warrant for Gaddafi by the ICC, in that it could undermine the work of the committee. Despite this and the AU's decision taken at the AU summit in Equatorial Guineaon 2 July 2011 that African states would not execute the arrest warrant, all of the indications are that South Africa and other African states that share its sentiments would have upheld their obligations under the Rome Statute and their corresponding domestic laws that incorporate the Statute and abided by the ICC request for Gaddafi's arrest and surrender, as they did with Al-Bashir.

The motivation for the AU's decisions not to cooperate in the Al-Bashir and Gaddafi cases differs. The AU based its decision in the Al-Bashir case on article 98, and at the Review Conference of the ICC held in Kampala, Uganda on 31 May to 11 June 2010 the chair of the AU stated that the indictment of heads of state could jeopardise effective co-operation with the ICC. In its decision on the indictment of Gaddafi, the AU did not rely on article 98, but rather on article 16, expressing the conviction that the warrant seriously undermines the AU's role as regional organisation in the prevention, management and resolution of conflicts intended to complement the Security Council's primary responsibility, namely the maintenance of international peace and security in accordance with the UN Charter. Furthermore, the AU held that the intervention by the Security Council complicated its efforts to negotiate a peaceful political settlement between Gaddafi's forces and the Libyan rebels, which would have ended the conflict and solved the crisis in Libya.

The merits of the AU's assumption that deferring the Gaddafi prosecution was essential to the peace initiatives in Libya can be debated extensively, but the following remarks are sufficient to make the point. ${ }^{67}$ The situation in Libya did not warrant a 'trade-off between peace and justice. There is a difference between providing impunity in pursuit of political stability and peace and allowing a tyrant to hold an entire nation captive by the threat of violence. By way of comparison the situation in Sudan was much closer to fitting the bill than Libya. In Sudan, AlBashir, as the leader of a ruling party, was at the centre of two parallel political

\footnotetext{
${ }^{66}$ Ian Black, 'Libya regime change is west's goal, but doubts remain over how to achieve it' The Guardian (15 April 2011) <http://www.guardian.co.uk/world/2011/apr/15/libya-regime-changeanalysis $>$ accessed 20 February 2012.

67 Christopher Gevers, 'The AU Qadhafi decision: some initial thoughts' (7 July 2011) <http://warandlaw.blogspot.com/\#!/2011/07/au-qadhafi-decision-some-initial.html> accessed 7 July 2011.
} 
negotiations, one with Darfur where his alleged crimes took place and the other with Southern Sudan. In contrast, Gaddafi refused to stand down and acted as a stumbling block to political negotiations. Not only does such a compromise challenge the integrity of the international justice system, but it also sets a precedent by providing an incentive for incumbents to use the threat of violence as a negotiating tool.

The reason why the AU did not rely on article 98 in the Gaddafi case and did not request its member states to balance their obligations to the AU and the ICC could be that it benefitted from criticism levelled against the position it took on the Al-Bashir indictment and that its evaluation thereof resulted in a better understanding of the relationship between articles 27(2) and 98(1). It could also be that the $\mathrm{AU}$ came to the realisation that some of its member states have obligations towards the ICC and that a formal request for a deferral of prosecution in terms of article 16 would be a better (lawful) option. Perhaps the AU believed it would be more persuasive to include its deferral request in its official decision, especially in view of its previous unsuccessful deferral request.

\section{Conclusion}

The recent situations in Sudan and Libya were referred to the ICC by the Security Council, and consequently the ICC was under a duty to act independently under the Rome Statute in response. The issuing of the indictments by the ICC was severely criticised although it was not responsible for the actions of the Security Council in referring the Sudan and Libya matters to it. Against this background the AU's decisions on the indictments of Al-Bashir and Gaddafi not to cooperate with the ICC renewed tension between the AU and the ICC and placed pressure on the court's success and future in Africa.

What should be recognised, despite the criticisms, are the serious violations of human rights in Sudan and Libya that threatened international peace and security, and that intervention was imperative. The efficacy of the kind of intervention and its timing can, however, be debated. On the one hand, the Security Council and the ICC can be applauded for taking bold action in their fight against impunity by intervening for the first time during an on-going conflict and by disregarding the customary rule on the personal immunity of serving heads of state in issuing arrest warrants for Al-Bashir and Gaddafi. On the other hand, regional efforts for longterm peace on the continent should not to be undermined, considering the serious commitment to working for peace that the AU and its member states have shown thus far. Intervention therefore did not necessarily have to be prosecution, but in the absence of compelling evidence showing that peace initiatives were making progress, it would have been difficult to convince the Security Council that the ICC's involvement was not one of the few means by which both the interests of long-term peace and justice could be secured. The call for 'African solutions to 
African problems' is therefore not without merit, when the proposed solutions are viable and consistent with the obligations of African states under international law.

Regarding the cumbersome relationship between the search for peace and the demands for justice, with particular reference to the AU's deferral request in the Al-Bashir case, it became clear from the expert study that the AU could have made better use of article 16 or have explored other options such as those that articles 17 and 53 provide for.

Pertaining to the irrelevance of the personal immunity of heads of state before an international forum, it has been found debatable whether this proposed new rule of customary international law has either met the usus and opinion juris requirements to become a customary international rule, or that its status has been elevated to that of a jus cogens norm or an obligation erga omnes.

The contention that articles 27(2) and 98(1) should be interpreted as complementing one another is found to be convincingly made. An article 27(2) waiver of personal immunity guarantees the exercise of the ICC's jurisdiction where States parties are involved, and article 98(1) seeks to secure the cooperation of non-States parties by acknowledging that the ICC cannot proceed with such a request unless such a 'third state' waives the personal immunity of its nationals. This view is in conformity with the Vienna Convention on the Law of Treaties, which states that the provisions of a treaty bind only parties thereto, and has been found to support the argument that the irrelevance of the personal immunity of serving heads of state before the ICC has not yet reached the status of a customary international law rule. As long as there is no decisive ruling by the ICC on the exact relationship between articles 27(2) and 98(1) or an amendment of article 98(1) to the effect that it applies to non-States parties only, the resulting uncertainty will continue to be exploited by uncooperative States parties, as has recently been the case.

The AU's decision on the indictment of Al-Bashir was clearly motivated by resentment towards the Security Council due to its unsuccessful deferral request. Furthermore, the AU's unqualified reasoning on the issue of personal immunity is not in compliance with the Rome Statute and customary international law. The distinction between States parties and non-States parties to the Rome Statute is not clearly made for the sake of establishing international obligations under the Statute. In hindsight the $\mathrm{AU}$ at least acknowledged this difficulty when it requested its member states to balance their obligations to the AU and the ICC.

The criticisms levelled against the AU in the Al-Bashir case probably influenced its decision on the indictment of Gaddafi in that the AU did not use the article 98(1) argument, but rather made another attempt at article 16. This deferral request would, however, have suffered the same fate. The situation in Libya did not warrant a compromise. Instead, the integrity of the international justice system was challenged in such a way as to set a precedent for incumbents to use the threat of violence as a negotiating tool.

If it is true that scrutiny and debate assisted the AU in coming to a better understanding of its members' international obligations and its status in relation 
thereto, then there is a necessity, as the expert study recommends, for greater dialogue and consensus building among African States parties (within and outside the forum of the $\mathrm{AU}$ ) as well as with all interested stakeholders, including the UN and the ICC. Ideally the UN, ICC and regional organisations like the AU should work together and not undermine one another's initiatives.

Few African states have enacted domestic legislation implementing the Rome Statute, and only some of them have taken a strong stance against impunity by disregarding the customary international law rule on the personal immunity of serving heads of state, despite the AU's calls to uphold the same. It is proposed here that this standpoint can serve as an example to other African states that have yet to domesticate the Rome Statute. The AU's decision nevertheless persuaded other African states, who are States parties to the Rome Statute, to act contrary to their article 27(2), 86 and 87 obligations by unlawfully disregarding the ICC's requests for cooperation.

It is unfortunate that the relationship between the AU, the UN and the ICC has deteriorated, resulting in the AU's decision not to cooperate with the ICC any further. It is recommended here that the AU should acknowledge that many of its member states have international obligations towards the ICC, which take precedence over their loyalty to the AU. Clearly the recent developments have a negative impact on the implementation of the Rome Statute in Africa in that the AU's decisions could discourage those African states that are not States parties to the Rome Statute from ratifying and implementing the Statute, and in that it could encourage African states that are States parties to withdraw. 



\section{List of editors and authors}

Ambos, Kai - Professor of Criminal Law, Criminal Procedure, Comparative Law and International Criminal Law at the Georg-August Universität Göttingen; Judge at the District Court (Landgericht) Göttingen.

Asaala, Evelyne Owiye - LLB UON, LLM UP, Law lecturer, The University of Nairobi.

Du Plessis, Max - Bluris (SA), LLB (Natal), LLM (Cantab); Associate Professor, Faculty of Law, University of KwaZulu-Natal, Durban; Associate Member of the KwaZulu-Natal Bar; Senior Research Associate, International Crime in Africa Programme, Institute for Security Studies.

Garuka, Christian Nsabimana - Legal Practitioner and Human Rights Researcher; LLM in Human Rights and Democratisation in Africa (University of Pretoria); LLB (National University of Rwanda).

Gevers, Christopher - Lecturer, School of Law, University of KwaZulu-Natal.

Kemp, Gerhard - Professor of Criminal Law and International Criminal Law, Stellenbosch University, South Africa.

Klein, Sabine - Researcher, Doctoral Candidate, Georg-August University of Göttingen/Faculty of Law; practicing lawyer admitted to the German bar.

Lubbe, Hendrik Johannes - LLB (NWU); LLM (UP); PhD (UVT). Senior Lecturer: North-West University (Potchefstroom Campus).

Maunganidze, Ottilia Anna - LLB (Rhodes), PDIS (Rhodes), LLM (UNISA); Researcher, International Crime in Africa Programme, Institute for Security Studies.

Meyersfeld, Bonita - BA (Stel); LLB (Wits) (cum laude); LLM (Yale); JSD (Yale). Associate Professor of Law, University of the Witwatersrand, Johannesburg; managing editor, South African Journal on Human Rights. 
Ngondji Ongombe, Lievin - Maître, Avocat près la Cour d'Appel de Kinshasa/Gombe, Membre du Barreau Pénal International, Conseil devant la Cour Pénale Internationale et Mandataire en propriété Industrielle. 
$T$ his book contains some of the papers that were presented at the first meeting of the newly formed African Expert Study Group on International Criminal Law/ Groupe des Experts Africaines en Droit Pénal International held in September 2011 in Brussels, Belgium. The group was established under the auspices of the Multinational Development Policy Dialogue (hereinafter 'MDPD') and the Rule of Law programme of the German Konrad-Adenauer-Stiftung ('KAS') in 2010 modeled on the successful sister group in Latin America. This latter group was originally founded as an expert group to monitor the implementation of the Rome Statute of the International Criminal Court ('ICC') in Latin America within the framework of cooperation between KAS' regional Rule of Law Programme and the Department for Foreign and International Law of the Institute for Criminal Law and Criminal Justice of the Georg-August-Universität Göttingen in 2002.

The newly formed African group consists of judicial experts with both academic and practical background from various parts of Sub-Saharan Africa. The importance of such a group for the African continent cannot be overestimated. Africa plays a vital role in international criminal law and justice, both as an active player at the ICC and at the regional and national level. As for the group's composition and outreach, the aim is to broaden regional representation and further consolidate membership. In 2012, the group will meet in Nairobi, Kenya to deal with topics surrounding the 'Potential for the domestic prosecution of international crimes in Africa.' Topics for future meetings abound given the multi-faceted African legal and political practice regarding international criminal justice in general and the ICC in particular. The group should in particular monitor the recent international or transnational criminal justice developments at the regional African level as well as relevant national developments. (Excerpt from the introduction by Kai Ambos) 